\title{
Marketing terytorialny \\ w ujęciu \\ relacyjnym
}


盗 


\section{Zarządzanie}

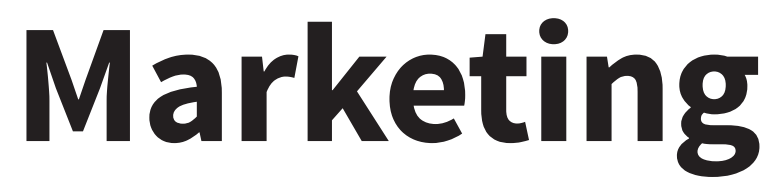

terytorialny

w ujęciu

relacyjnym

Wawrzyniec Rudolf 
Wawrzyniec Rudolf - Uniwersytet Łódzki, Wydział Zarządzania

Katedra Zarządzania Miastem i Regionem, 90-237 Łódź, ul. Jana Matejki 22/26

\author{
RECENZENT \\ Andrzej Szplit \\ REDAKTOR INICJUJĄCY \\ Monika Borowczyk \\ REDAKTOR WYDAWNICTWA UŁ \\ Dorota Stępień
}

SKŁAD I ŁAMANIE

Munda-Maciej Torz

PROJEKT OKŁADKI

Stämpfli Polska Sp. $z$ o.o.

Zdjęcie wykorzystane na okładce: @ Shutterstock.com

(C) Copyright by Wawrzyniec Rudolf, Łódź 2016

(C) Copyright for this edition by Uniwersytet Łódzki, Łódź 2016
Wydane przez Wydawnictwo Uniwersytetu Łódzkiego
Wydanie I. W. 06555.14.0.M

Ark. wyd. 14,3; ark. druk. 17,0

ISBN 978-83-8088-289-8

e-ISBN 978-83-8088-290-4

\author{
Wydawnictwo Uniwersytetu Łódzkiego \\ 90-131 Łódź, ul. Lindleya 8 \\ www.wydawnictwo.uni.lodz.pl \\ e-mail: ksiegarnia@uni.lodz.pl \\ tel. (42) 6655863
}




\section{Spis treści}

Wstęp

Rozdział 1

\section{Ewolucja zarządzania publicznego w kierunku} relacyjnym

1.1. Różnice między zarządzaniem w sektorze publicznym i prywatnym 20

1.2. Ewolucja zarządzania publicznego w kierunku otwartości organizacji 23

1.2.1. Model biurokratyczny (Public Administration - PA) 25

1.2.2. Nowe zarządzanie publiczne (New Public Management - NPM) 27

1.2.3. Wspótrządzenie publiczne (Public Governance - PG) 30

1.3. Partnerskie zarządzanie publiczne $\quad 35$

$\begin{array}{ll}\text { 1.4. Podsumowanie } & 38\end{array}$

Rozdział 2

\section{Marketing terytorialny w ujęciu transakcyjnym} i relacyjnym 41

2.1. Marketing w sektorze publicznym $\quad 42$

2.1.1. Sektor publiczny a rynek w badaniach naukowych 42

2.1.2. Kierunki rozwoju marketingu w sektorze publicznym 47

2.2. Geneza i rozwój marketingu terytorialnego 50

2.2.1. Geneza marketingu terytorialnego 50

2.2.2. Typologia podejść badawczych w marketingu terytorialnym 51

2.2.3. Rozwój marketingu terytorialnego w Polsce 54

2.3. Marketing relacji w sektorze przedsiębiorstw 57

2.3.1. Rozwój marketingu relacji w sektorze przedsiębiorstw 57

2.3.2. Marketing interesariuszy jako nowy wymiar marketingu relacji 66

$\begin{array}{ll}\text { 2.4. Marketing relacji w sektorze publicznym } & 71\end{array}$

$\begin{array}{ll}\text { 2.5. Podsumowanie } & 74\end{array}$ 
Rozdział 3

\section{Rozwój relacji międzyorganizacyjnych \\ w sektorze publicznym}

3.1. Rola partnerstwa w rozwoju terytorialnym 78

3.2. Rodzaje relacji międzyorganizacyjnych i ich rozwój 84

3.3. Teorie opisujące współdziałanie międzyorganizacyjne 91

3.3.1. Teoria zależności od zasobów (resource dependency theory) 92

3.3.2. Teoria wymiany relacyjnej (relational exchange theory) 94

3.3.3. Teoria kosztów transakcyjnych (transaction cost theory) 95

3.4. Typologie współdziałania międzyorganizacyjnego 97

$\begin{array}{ll}\text { 3.4.1. Rodzaje i wymiary relacji partnerskich } & 97\end{array}$

3.4.2. Relacje międzyorganizacyjne w warunkach polskich samorządów województw 99

$\begin{array}{ll}\text { 3.5. Podsumowanie } & 103\end{array}$

Rozdział 4

Metodyka badań empirycznych

105

4.1. Przesłanki prowadzonych badań i założenia badawcze 107

4.2. Operacjonalizacja pojęć 109

4.3. Uzasadnienie wyboru wielokrotnego studium przypadku jako metody badań 114

4.4. Etapy badania oraz wykorzystywane metody i narzędzia badawcze $\quad 116$

4.4.1. Studia literaturowe i analiza bibliometryczna (etap 1) 117

4.4.2. Badania eksploracyjne (etap 2) 118

4.4.3. Badanie relacji region-miasto (etap 3) 127

$\begin{array}{ll}\text { 4.5. Podsumowanie } & 133\end{array}$

Rozdział 5

Organizacja terytorialna i jej relacje

$z$ interesariuszami instytucjonalnymi

w kontekście prowadzenia polityki rozwoju

- wyniki badań empirycznych

5.1. Ocena otwartości organizacji terytorialnej i jej interesariuszy instytucjonalnych w opinii menedżerów

5.1.1. Otwartość organizacji terytorialnej (urzędu marszałkowskiego) i jej interesariuszy instytucjonalnych w ocenie badanych menedżerów

5.1.2. Identyfikacja partnerów do współpracy dla organizacji te-

rytorialnej na szczeblu regionu

5.1.3. Badanie otwartości organizacji terytorialnej metodą „tajemniczy klient" (mystery client)

5.2. Czynniki wpływające na współpracę zewnętrzną organizacji terytorialnej 148

5.2.1. Czynniki skłaniające do współpracy i utrudniające współpracę $\quad 149$

5.2.2. Czynniki charakteryzujące współpracę organizacji terytorialnej z podmiotami publicznymi 
5.2.3. Czynniki charakteryzujące współpracę organizacji terytorialnej z partnerami niepublicznymi

5.2.4. Pożądane cechy publicznego i niepublicznego partnera do współpracy

5.3. Specyfika relacji organizacji terytorialnej na szczeblu regionu z lokalnymi JST

5.3.1. Obszary merytoryczne we współdziałaniu samorządu województwa z lokalnymi JST

5.3.2. Ocena zaangażowania kierownictwa organizacji terytorialnej we współdziałanie z lokalnymi JST oraz ocena typowych propozycji usprawnień tego procesu

5.3.3. Współpraca zarządu województwa z podmiotami instytucjonalnymi w ocenie interesariuszy instytucjonalnych

5.3.4. Postawy menedżerów publicznych wobec propozycji usprawniania procesu współdziałania region-lokalne JST

Rozdział 6

\section{Współdziałanie regionu i miasta w marketingowych procesach pozyskiwania mobilnych czynników wzrostu - wyniki badań empirycznych}

6.1. Rola miast i regionów $w$ dysponowaniu zasobami

6.2. Klasyfikacja regionów ze względu na udział stolicy w zasobach regionu ogółem

6.3. Oceny potencjału stolicy w regionie z perspektywy atrakcyjności inwestycyjnej, turystycznej i akademickiej

6.3.1. Rola stolicy w regionie na rynku inwestycyjnym

6.3.2. Rola stolicy w regionie na rynku turystycznym

6.3.3. Rola stolicy w regionie na rynku akademickim

6.3.4. Zasoby stolicy $w$ regionie $w$ ujęciu syntetycznym

6.4. Ocena współdziałania pomiędzy regionem a miastem $w$ zakresie realizacji procesów marketingowych

6.4.1. Kryteria oceny $i$ ich wagi

6.4.2. Ocena subiektywna współdziałania dokonana przez menedżerów relacji

6.4.3. Miary obiektywne współdziałania

6.5. Zestawienie wyników badań i ich interpretacja

Zakończenie

Bibliografia

Summary

Załączniki

Spis tabel, rysunków i załączników 



\section{Wstęp}

Jednostki samorządu terytorialnego stanowią szczególny przypadek podmiotów publicznych, realizują bowiem zarówno funkcje związane z kreowaniem polityki publicznej na poziomie regionalnym czy lokalnym, jak i świadczą publiczne usługi kierowane do mieszkańców i innych użytkowników terytoriów. Jednocześnie samorządy te pełnią coraz ważniejsze funkcje w strukturach państwa, otrzymując zgodnie z zasadą subsydiarności coraz szersze zadania i kompetencje. Coraz większe są też środki publiczne będące w ich dyspozycji. Dzieje się tak m.in. dzięki włączaniu tych jednostek, a zwłaszcza samorządów wojewódzkich, w procesy planowania, implementacji oraz kontroli polityki spójności Unii Europejskiej. Szczeblem, który posiada przewagę funkcji związanych z kreowaniem i wdrażaniem polityki publicznej nad dostarczaniem usług publicznych jest samorządowy region, którego organizacyjny wymiar (urząd marszałkowski wraz z jego kierownictwem) będziemy nazywać w niniejszej monografii organizacją terytorialną (OT) na szczeblu regionu.

Procesy globalizacji i regionalizacji zachodzące w Europie i na świecie sprawiły, że miasta i regiony muszą coraz intensywniej rywalizować między sobą o mobilne zasoby - czynniki wzrostu. Nawet zmiana paradygmatu rozwoju terytorium i oparcie go na czynnikach endogenicznych nie zmniejszyła potrzeby przyciągania zasobów spoza regionu - zewnętrznych czynników wzrostu (kapitału, siły roboczej, wiedzy itp.). Zmieniły się natomiast wartości, wokół których zaczęto budować przewagi terytoriów, oraz techniki skutecznego oddziaływania na potencjalnych zewnętrznych użytkowników, będących w posiadaniu cennych dla rozwoju terytorium zasobów.

Praca została poświęcona budowaniu relacji międzyorganizacyjnych przez samorządy terytorialne $\mathrm{w}$ obszarze ich działan marketingowych, zorientowanych na pozyskiwanie mobilnych zasobów rozwojowych z rynków: inwestorów, turystów oraz studentów. Autor podjął próbę 
odnalezienia teoretycznych punktów odniesienia dla koncepcji marketingu interesariuszy, adaptowanej z sektora przedsiębiorstw, do jednostek samorządu terytorialnego w obszarze działań strategicznych, związanych $\mathrm{z}$ budowaniem przewagi konkurencyjnej na rynkach potencjalnych użytkowników (inwestorów, turystów i studentów).

Analiza literatury naukowej z zakresu wykorzystywania koncepcji marketingu $\mathrm{w}$ odniesieniu do terytorium pozwala na wyodrębnienie dwóch charakterystycznych nurtów. Pierwszy, reprezentowany przez geografów społeczno-ekonomicznych, planistów przestrzennych, specjalistów od polityki rozwoju, jest nacechowany przestrzennym wymiarem marketingu terytorialnego ${ }^{1}$. Punktem wyjścia jest tu przestrzeń zamknięta $\mathrm{w}$ administracyjnych granicach (miasto, województwo) lub, rzadziej, przekraczająca je (krainy geograficzne czy obszary gospodarcze). W nurcie tym znajdą się zatem wszelkie studia związane z rozwojem lokalnym i regionalnym, a zwłaszcza z kreowaniem konkurencyjności przestrzennej poprzez dążenie do delokalizacji (przyciągania) czynników rozwoju czy uspołecznieniem procesów planowania przestrzennego. Autorzy ci upraszczają istotę marketingu w odniesieniu do terytorium, zaś w swoich badaniach koncentrują się na czynnikach rozwoju terytorium, na znaczeniu i efektach spektakularnych miejskich projektów oraz na promocji terytorium opartej zwłaszcza na zasobach fizycznych danej przestrzeni ${ }^{2}$.

Drugi nurt jest reprezentowany przez specjalistów z zakresu marketingu przedsiębiorstw oraz zarządzania marketingowego. Autorzy starają się tu aplikować koncepcję marketingu podmiotów gospodarczych zarówno na poziomie strategicznym, jak i operacyjnym do procesów planowania, a także realizacji polityki rozwoju terytorialnego. Jedni postrzegają marketing jako element procesu zarządzania marketingowego ${ }^{3}$, inni natomiast jako sposób lepszego zaspakajania potrzeb lokalnej społeczności. Tzw. background tych autorów jest związany z marketingiem i zarządzaniem (w sektorze przedsiębiorstw). Większość z nich koncentruje się jednak na rozwijaniu marketingu terytorialnego (MT), w kierunku budowania marki terytorialnej, którą traktuje się tu jako element zarządzania strategicznego terytorium. Marka terytorialna staje się niewątpliwie tym elementem nurtu, którego popularność, zwłaszcza w ostatnich latach,

1 Elementy tego rodzaju marketingu znaleźć można w pracach takich autorów, jak: Ashworth, Voogd [1988, s. 65-79], Ashworth, Voogd [1990], Ashworth, Kavaratzis [2008, s. 150-165], Olsson, Berglund [2009].

2 Do publikacji poświęconych tej problematyce można zaliczyć: Gold, Ward [1994], Eisinger [2000], Markowski [1997b, s. 50-58].

3 Marketing jako element zarządzania dominuje m.in. w publikacjach takich badaczy, jak: Kotler et al. [1993, 1999, 2002], Rainisto [2003], Domański [1997], Szromnik [2008]. 
szybko rośnie. Utożsamianie marketingu terytorialnego tylko z procesem budowania marki byłoby jednak nieuzasadnionym zawężeniem tej koncepcji w zarządzaniu strategicznym terytorium.

Autor niniejszej monografii zdecydował się wpisać swe rozważania w rozwój obu nurtów równocześnie. Przyjmuje tu kotlerowskie rozumienie marketingu terytorialnego, jednak stara się rozwinąć perspektywę relacyjną, która w dziełach $\mathrm{Ph}$. Kotlera odnoszących się do marketingu terytorialnego [1993, 1999, 2002] została tylko zasygnalizowana. Jednocześnie starał się uwzględnić bardziej niż przedstawiciele tego nurtu specyficzną rolę regionu w prowadzeniu polityki rozwoju oraz jego relacje ze stolicą województwa.

Dotychczasowa koncepcja marketingu terytorialnego stanowi próbę wykorzystania klasycznego marketingu w zarządzaniu organizacjami terytorialnymi. Opiera się na marketingu transakcyjnym, ukształtowanym w latach 60. i 70. XX w. w sektorze przedsiębiorstw. Zgodnie z tą koncepcją głównym zadaniem jednostek samorządu terytorialnego (JST) ma być zaspakajanie potrzeb lokalnych mieszkańców oraz innych użytkowników terytoriów. Jednak, zdaniem autora, ograniczona mobilność mieszkańców sprawia, że traktowanie ich jako docelowych klientów może budzić kontrowersje, nie występuje tu bowiem sytuacja w pełni konkurencyjna. Przeciętny mieszkaniec nie ma realnej możliwości zmiany miejsca zamieszkania w sytuacji, kiedy nie spodoba mu się sposób zarządzania przez lokalne władze i menedżerów im podległych. O jego mobilności, będącej warunkiem wykorzystania koncepcji marketingu w odniesieniu do terytoriów, decydują warunki ekonomiczne, kulturowe, ale także prawne czy administracyjne.

Dotychczasowe piśmiennictwo z zakresu MT koncentruje się głównie, jak wspominano, na budowaniu marki miejsca oraz na skutecznym komunikowaniu się, co miało pozytywnie wpływać na zainteresowanie potencjalnych użytkowników danym terytorium. Pomimo pojawienia się kilku opracowań, gdzie MT definiowany był szeroko, jako filozofia zarządzania miastem czy regionem, $w$ ich ślad nie poszły szersze badania prowadzone na ten temat. Powstała luka badawcza, zwłaszcza w zakresie traktowania marketingu terytorialnego jako koncepcji strategicznego kształtowania relacji terytorium $\mathrm{z}$ jego instytucjonalnymi interesariuszami. Obszar ten jest natomiast dobrze opisany, ale w odniesieniu do sektora przedsiębiorstw (zarządzanie strategiczne). Jedną z bazowych teorii jest tu teoria interesariuszy, która mimo upływu lat, nadal się rozwija i znajduje zastosowanie w opisie nowych obszarów czy zjawisk [Freeman et al. 2010, Palmar 2010, s. 403-445]. Przykładowym obszarem może być sektor publiczny, a przede wszystkim samorządy terytorialne, gdzie można ją wykorzystać, zwłaszcza w zakresie marketingu strategicznego. 
W naukach o zarządzaniu obserwujemy coraz szerszy trend wykorzystywania istniejącego dorobku wypracowanego na potrzeby sektora przedsiębiorstw do organizacji publicznych [Ferlie et al. 1996; Hood 1991]. Aby organizacje te mogły skutecznie realizować powierzone im zadania w określonych zakresach, muszą działać na rynkach i rywalizować z innymi organizacjami o zewnętrzne zasoby, których pozyskanie umożliwi pełniejsze wywiązywanie się z powierzonych im zadań wobec obywateli czy mieszkańców. W sektorze publicznym dokonuje się zmiana paradygmatu zarządzania. O ile wcześniej, przez dekady, dominował tzw. klasyczny model administracji, którego wyróżnikiem była hierarchia, to współcześnie nabiera znaczenia mechanizm rynkowy oraz budowanie relacji dwustronnych bądź sieciowych z podmiotami z otoczenia organizacji publicznych [Ferlie, Lynn, Pollitt 2005].

Zaowocowało to wyodrębnieniem się takich modeli zarządzania, jak Nowe Zarządzanie Publiczne czy Public Governance [Osborne 2010]. $\mathrm{W}$ rezultacie, $\mathrm{w}$ dyskursie naukowym zarówno tematyka rynku, będąca podstawą modelu Nowego Zarządzania Publicznego, jak i tematyka budowania relacji międzyorganizacyjnych, będąca podstawą modelu $\mathrm{Pu}$ blic Governance, systematycznie nabierały znaczenia, chociaż ich zakres jest zróżnicowany w poszczególnych krajach. Teorie, które do niedawna wykorzystywane były tylko do opisu zjawisk w sektorze przedsiębiorstw, obecnie znajduja zastosowanie $\mathrm{w}$ sektorze publicznym. Dotyczy to zwłaszcza takich obszarów, gdzie obok sektora publicznego działa sektor prywatny, a podmioty z obu tych sektorów rywalizują ze sobą (sektor ochrony zdrowia, sektor edukacji itp.). Należy podkreślić, że chodzi tu zwłaszcza o jeden z obszarów sektora publicznego, jakim jest świadczenie usług publicznych.

Dynamika współczesnego otoczenia oraz zmiany na rynku przedsiębiorstw tworzą nowe warunki, stawiając organizacjom publicznym wyzwania w zakresie ich dążenia do wzrostu ich otwartości na relacje międzyorganizacyjne. Autor postanowił podążać tym tropem, szukając możliwości opisu działalności organizacji terytorialnych przy pomocy teorii, które tradycyjnie były związane z budowaniem relacji międzyorganizacyjnych podmiotów zorientowanych na osiąganie zysku.

Formułowane niżej zarówno cel badawczy, jak i hipoteza główna mają charakter ogólny i dotyczą całej pracy. Szczegółowe cele oraz pytania czy hipotezy badawcze zostały zawarte $\mathrm{w}$ rozdziale metodologicznym i odnoszą się do poszczególnych etapów badań empirycznych.

Celem głównym pracy jest próba wyjaśnienia rozwoju koncepcji marketingu terytorialnego $w$ oparciu o teorie wspótdziałania międzyorganizacyjnego. Cel ten realizowano zarówno poprzez analizy o charakterze teoretycznym, jak i szerokie badania empiryczne, prowadzone w kilku 
województwach. W badaniach tych poszukiwano motywów nawiązywania relacji przez menedżerów publicznych z OT na szczeblu regionu z publicznymi i niepublicznymi interesariuszami instytucjonalnymi, w tym przede wszystkim z przedstawicielami miasta - stolicy regionu. Relacje te będziemy badać w kontekście prowadzenia działań marketingowych z wykorzystaniem teorii współdziałania międzyorganizacyjnego.

W pracy podjęto też próbę weryfikacji głównej hipotezy badawczej: realizacja koncepcji marketingu terytorialnego $w$ ujęciu relacyjnym poprzez działania OT na rzecz pozyskiwania zewnętrznych użytkowników regionu będących nośnikami mobilnych czynników rozwoju (inwestorów, turystów, studentów) opiera się na współdziałaniu międzyorganizacyjnym i opisujacych je teoriach, uwzględniających posiadane bądź kontrolowane przez zewnętrznych interesariuszy instytucjonalnych zasoby. W ocenie autora trudno współcześnie mówić o dominacji modelu governance w polskich samorządach terytorialnych. Są oczywiście jego symptomy, ale w świadomości badanych menedżerów w zarządzaniu publicznym nadal obecny jest model biurokratyczny oraz rynkowy, przejawiający się poprzez ich postawy wobec współdziałania międzyorganizacyjnego.

W niniejszej monografii przyjęto za R. Morganem [2007, s. 48-76] światopogląd pragmatyczny jako filozoficzną podbudowę dla wykorzystywanych tu badań mieszanych. Otwiera on drogę do oparcia badań na różnorodnych metodach, zróżnicowanych założeniach oraz wielu sposobach gromadzenia i analizowania danych. W pracy przyjęto mieszaną strategię badawczą, charakteryzującą się sekwencyjnością. Pozwoliło to, poprzez zastosowanie jednej metody, na uporządkowanie i uogólnienie wyników uzyskanych inną metodą. Rozpoczęto od badań eksploracyjnych, aby następnie bazując na wynikach tych badań, podjąć decyzję co do zawężenia obszaru badawczego i skoncentrowaniu się na wybranych relacjach, przypadkach i jednostkach badawczych.

W pracy wykorzystano dwa rodzaje badań. Pierwsze to badanie eksploracyjne, umożliwiające bliższe poznanie roli współpracy w kontekście prowadzonej na szczeblu regionu polityki rozwoju gospodarczego, ukierunkowanej na podnoszenie przewagi konkurencyjnej regionu, ze szczególnym uwzględnieniem działań podejmowanych przez jednostki organizacyjne urzędu marszałkowskiego. Badania te miały dostarczyć informacji na temat elementów otoczenia podmiotowego urzędu marszałkowskiego oraz wskazać te podmioty publiczne i niepubliczne (społeczne i prywatne), z którymi wspólpraca jest szczególnie istotna dla prowadzenia polityki rozwoju, realizowanej na szczeblu województwa. Badania miały pomóc określić charakter i potencjał takiej współpracy. Uwzględniono w nich zasadniczą rolę menedżera publicznego, która, zwłaszcza $\mathrm{w}$ takich dużych organizacjach, jest kluczowa dla budowania potencjału 
relacyjnego organizacji terytorialnej. Autor na podstawie wyników tych badań formułuje model sześciu rynków interesariuszy instytucjonalnych dla organizacji terytorialnej na szczeblu regionu, w kontekście prowadzenia polityki rozwoju. Nawiązuje przy tym do klasycznej teorii interesariuszy. Dla tej eksploracyjnej części badań wybrano cztery województwa: łódzkie, małopolskie, świętokrzyskie, wielkopolskie.

W ramach drugiego rodzaju badań dokonano wyboru jednej z sześciu zidentyfikowanych relacji we wspomnianym modelu sześciu rynków (region-lokalne JST). Natomiast na rynku lokalnych samorządów wybrano miasto-stolicę regionu jako ten podmiot, który ma relatywnie najsilniejszą pozycję wobec regionu, pośród wszystkich zidentyfikowanych interesariuszy instytucjonalnych. Poczynione tu obserwacje dotyczyły dwóch rodzajów relacji. Pierwszy to taki, gdzie stolica posiada relatywnie duże zasoby wobec zasobów całego regionu, oraz drugi, gdzie udział stolicy w zasobach regionu jest stosunkowo mały. W badaniu ostatecznie zidentyfikowano cztery pary region-miasto i starano się poprzez ich analizę weryfikować hipotezę związaną z teorią zależności od zasobów.

Wykorzystana $\mathrm{w}$ pracy metoda studium przypadku dobrze wpisuje się $\mathrm{w}$ przyjęty $\mathrm{w}$ pracy światopogląd pragmatyczny, a wiele technik badawczych w jej ramach pozwala na pełniejsze poznanie rzeczywistości. Za wyborem studium przypadku przemawia fakt niewielkiej liczby podmiotów publicznych, np. urzędów marszałkowskich będących przedmiotem badań. W metodzie tej nie wykorzystuje się do badań jednostek wyselekcjonowanych $\mathrm{w}$ reżimie próby statystycznej, ale stosowane jest podejście replication approach [Yin 2009, s. 56]. Owa replikacja przypadków i przyglądanie się wycinkowi rzeczywistości z różnych perspektyw pozwala zidentyfikować problemy, które inaczej nie byłyby możliwe do dostrzeżenia. W kontekście badania organizacji terytorialnych polskich samorządowych województw, które w niniejszym badaniu są utożsamiane w urzędami marszałkowskimi, pełniącymi ważną rolę zarówno w kreowaniu, jak i realizacji polityki rozwoju na szczeblu województwa, metoda studium przypadku wydaje się optymalna, co starano się uzasadnić $\mathrm{w}$ rozdziale czwartym.

Wyżej wymienionym celom podporządkowano układ pracy. Składa się ona z sześciu rozdziałów. Trzy pierwsze mają charakter teoretyczny i odnoszą się kolejno do: (1) procesów ewolucji zarządzania w sektorze publicznym, (2) problematyki marketingu terytorialnego czy marketingu relacji i interesariuszy oraz (3) relacji międzyorganizacyjnych. Rozdział czwarty to część metodyczna pracy, odnosząca się do badań empirycznych. Rezultaty prowadzonych badań zostały szeroko opisane w rozdziałach piątym i szóstym, z których pierwszy poświęcono zagadnieniom relacji OT z jej interesariuszami instytucjonalnymi w kontekście budowania 
konkurencyjności regionu, drugi zaś - jednej z wybranych relacji, badanej w procedurze zbiorowego studium przypadku. Niżej zaprezentowano krótką charakterystykę poszczególnych rozdziałów pracy.

$\mathrm{W}$ rozdziale pierwszym ukazano proces ewolucji modeli zarządzania w sektorze publicznym, ze szczególnym uwzględnieniem warunków sprzyjających wykorzystywaniu w tym sektorze koncepcji marketingu. Warto zauważyć, że ewolucja ta dokonywała się w dużej mierze pod wpływem rozwiązań stosowanych w sektorze prywatnym. Zwrócono uwagę na różnice między zarządzaniem w sektorze publicznym i prywatnym, ale wskazano też na wiele występujących między nimi podobieństw. Ważne miejsce $\mathrm{w}$ tej części pracy zajmuje ponadto tzw. partnerskie zarządzanie publiczne, do którego rozwoju przyczyniła się zarówno koncepcja governance, jak i istniejące w poszczególnych krajach instytucje nieformalne.

Proces rozwoju marketingu terytorialnego omówiono w rozdziale drugim. Marketing zaczął być użyteczny dla sektora publicznego wraz $\mathrm{z}$ pojawianiem się, omawianych $\mathrm{w}$ rozdziale pierwszym, modeli zarządzania publicznego opartych na rynku (NPM) czy sieciach współpracy (Public Governance). Popularyzacji marketingu w sektorze publicznym sprzyjały takie elementy, jak: tworzenie rynków wewnętrznych w sektorze publicznym, rozwój współpracy z sektorem prywatnym w ramach formuły partnerstwa publiczno-prywatnego czy rozwój międzyorganizacyjnego współdziałania. Coraz szersze jego wykorzystywanie w jego klasycznej, transakcyjnej postaci miało na celu podniesienie efektywności sektora publicznego i zmniejszenie $\mathrm{w}$ ten sposób dystansu do sektora prywatnego. Jako alternatywne podejście autor zaprezentował koncepcję marketingu relacji w sektorze publicznym, poprzedzając tę część opisem koncepcji marketingu relacji w sektorze przedsiębiorstw pod kątem identyfikacji takiego ujęcia, jakie może być przydatne do zastosowania w sektorze publicznym. Dlatego nieco uwagi poświęcono również węższej koncepcji - marketingowi interesariuszy, który może stać się bardzo przydatny w działaniach marketingowych organizacji terytorialnych.

Rozdział trzeci poświęcono rozwojowi relacji międzyorganizacyjnych w sektorze publicznym, nazywanych również współdziałaniem bądź partnerstwem. Odgrywają one obecnie coraz większą rolę w zarządzaniu publicznym. Rozwój partnerskich relacji stanowi w dużej mierze rezultat zmian w poziomie wykształcenia czy szerzej - w poziomie dobrobytu społecznego. Jednak za główną przyczynę takiego rozwoju przyjmuje się tu konieczność pozyskiwania przez organizacje publiczne zasobów niezbędnych do realizacji celów tych organizacji. Teoretyczną podstawę dla takiego rozwoju stanowią: szeroko omawiana teoria zależności od zasobów, a także teoria wymiany relacyjnej czy teoria kosztów transakcyjnych. 
Rozwój relacji partnerskich w kontekście prowadzenia polityki rozwoju, szczególnie w krajach postkomunistycznych, jest w dużej mierze inspirowany przez struktury Unii Europejskiej. Dzieje się tak za sprawą funduszy unijnych, finansujących politykę spójności UE, których pozyskanie jest często uwarunkowane zaistnieniem takiego partnerstwa na szczeblach: krajowym, regionalnym i lokalnym.

Czwarty rozdział ma charakter metodologiczny. Ze względu na charakter prowadzonych badań, z udziałem relatywnie niewielkiej liczby respondentów, również metoda badań musiała być adekwatna do specyfiki podjętych problemów. Wykorzystano metodę zbiorowego studium przypadku. Badania przeprowadzono w trzech etapach, z których drugi i trzeci to odrębne badania empiryczne. Dla każdego z nich przygotowano odrębne cele badawcze, odrębne pytania badawcze i hipotezy badawcze. Ze względu na wspomnianą specyfikę, w rozdziale znalazła się operacjonalizacja pojęć, a więc opis terminów wykorzystywanych w badaniach. Wspomniana metoda wymaga precyzyjnego doboru przypadków do badań, stąd w rozdziale szczegółowo omówiono procedurę takiego doboru.

W rozdziale piątym zaprezentowano rezultaty pierwszej części badań empirycznych. Przyjęto założenie, że poszczególne jednostki organizacyjne OT wykazują różną zdolność zachowań kooperacyjnych w relacjach międzyorganizacyjnych. W związku z tym dokonano podziału jednostek wchodzących w skład organizacji terytorialnej (urzędu marszałkowskiego) na trzy rodzaje. Analiza rezultatów prowadzonych badań ujawniła, że szczególnie dla nas interesujące są postawy przedstawicieli tzw. jednostek rynkowych, które utożsamiać można z jednostkami marketingowymi. W rozdziale tym przedstawiono wyniki badań dotyczące otwartości organizacji terytorialnej, czynników wpływających na współpracę, relacji samorządu wojewódzkiego z lokalnymi jednostkami terytorialnymi i szereg innych.

Rezultaty drugiej części badań empirycznych przedstawiono w rozdziale szóstym. Skoncentrowano się tu na relacji region-miasto (stolica). Opisano tę relację z perspektywy teorii zależności od zasobów, w kontekście realizacji przez region marketingowych procesów pozyskiwania inwestorów, turystów i studentów. Zastosowano tu metodę wielokrotnego studium przypadków, wyróżniając przypadek A, gdzie stolica posiada wysoki udział w zasobach całego regionu oraz przypadek B, gdzie stolica posiada relatywnie mało zasobów na tle regionu. Przy czym wzięto pod uwagę te zasoby, które są ważne z punktu widzenia wspomnianych wyżej trzech grup docelowych. Przyjęto mierniki współdziałania region-miasto pozwalające na ocenę poziomu współdziałania w zakresie działań marketingowych i wyciągnięcie stosownych wniosków. 
Monografia jest kierowana do osób zainteresowanych poszerzaniem koncepcji marketingu, prowadzących badania naukowe w tym zakresie. Zwłaszcza tych, którzy chcą poszerzyć wiedzę z zakresu marketingu terytorialnego zarówno z perspektywy naukowej, jak i praktycznej (lokalni politycy i menedżerowie publiczni). Ze względu na to, że opracowanie zawiera rozdziały teoretyczne o szerokiej zawartości - od rozwoju modeli zarządzania publicznego, przez marketing w sektorze publicznym, po współdziałanie międzyorganizacyjne, rozbudowane wątki metodyczne oraz obszerne wyniki badań empirycznych może okazać się ono przydatne w procesach dydaktycznych dla uczestników studiów podyplomowych i studentów drugiego stopnia kierunków związanych z zarządzaniem publicznym czy marketingiem terytorialnym.

Autor składa podziękowania i przekazuje wyrazy szacunku Panu Profesorowi Tadeuszowi Markowskiemu, kierownikowi Katedry Zarządzania Miastem i Regionem na Wydziale Zarządzania. Bez wsparcia Pana Profesora, jego inspiracji do prowadzenia badań naukowych oraz życzliwości współpracowników monografia ta by nie powstała. Podziękowania autor kieruje również do Profesora Tomasza Domańskiego, kierownika Katedry Marketingu Międzynarodowego i Dystrybucji, gdzie autor nabywał doświadczenie marketingowe i spędził pierwsze inspirujące lata jako doktorant i adiunkt Wydziału Studiów Międzynarodowych i Politologicznych. 



\section{Rozdział 1}

\section{Ewolucja zarządzania publicznego w kierunku relacyjnym}

Rozdział ma charakter wprowadzenia do badanej problematyki. Przedstawiono w nim specyfikę zarządzania w sektorze publicznym oraz jego ewolucję w kierunku rosnącej roli relacji międzyorganizacyjnych. Specyfika ta została pokazana na tle zarządzania w sektorze prywatnym, który jest punktem odniesienia dla sektora publicznego. Rozważania rozpoczniemy więc od omówienia różnic między tymi sektorami. W tym celu wybrano czynniki związane z: (1) otoczeniem organizacji, (2) relacjami między organizacją i jej otoczeniem, a także (3) postawami i zachowaniami organizacyjnymi oraz motywowaniem. Przy prezentacji tych różnic zwracano jednocześnie uwagę na liczne podobieństwa między tymi sektorami.

W rozdziale tym główny akcent położono na procesy ewolucji zarządzania publicznego. Problematyka ta ma charakter interdyscyplinarny i początkowo była bardziej związana z naukami prawnymi, administracyjnymi czy politologią, zaś obecnie jest coraz częściej przedmiotem zainteresowania nauk ekonomicznych, w tym organizacji i zarządzania. Zarządzanie publiczne ma charakter dynamiczny, musi bowiem uwzględniać zmiany w otoczeniu współczesnych organizacji publicznych. Podlegało ono w ostatnich dekadach znacznej ewolucji, szczególnie w krajach o utrwalonych tradycjach demokratycznych i rynkowych zasadach funkcjonowania gospodarki. Proces ten przedstawiono, omawiając kolejno poszczególne modele zarządzania publicznego. Końcową część rozdziału poświęcono partnerskiemu zarządzaniu publicznemu. Rozwój relacji partnerskich stał się możliwy dopiero na określonym etapie rozwoju zarządzania publicznego. 


\subsection{Różnice między zarządzaniem w sektorze publicznym i prywatnym}

Dokonujące się w ostatnich dekadach zmiany w otoczeniu organizacji publicznych wpłynęły w zasadniczym stopniu na zmiany w sposobach ich zarządzania. Tradycyjny, biurokratyczny model administracji publicznej okazał się mało efektywny, stąd pojawily się naciski na jego reformowanie [Cooper, Brady 1998]. Wskazywano na potrzebę bardziej korzystnego wydawania środków publicznych, na poprawę jakości usług publicznych oraz na zwiększanie skuteczności działań organizacji publicznych. Przyniosło to zwrócenie uwagi na realizowany w sektorze prywatnym model menedżerski i podjęcie próby jego adaptacji do sektora publicznego [Hood 1991, s. 4-5]. Oczekiwano, że reforma zarządzania publicznego, polegająca na adaptacji metod i technik zarządzania wykorzystywanych w sektorze prywatnym, przyniesie poprawę efektywności realizowanych zadań.

Zdania na temat takiego reformowania systemu zarządzania publicznego były jednak podzielone i część autorów wskazywała na liczne różnice między sektorem publicznym i prywatnym, które mogą ograniczyć efektywność rozwiązań adaptowanych z sektora prywatnego. Różnice te, które przedstawimy poniżej, nie zahamowały jednak procesu reformowania sektora publicznego, na co wskazuje prowadzona dalej analiza poszczególnych modeli zarządzania publicznego. Prezentacja tych różnic pozwoli lepiej zrozumieć napotykane trudności przy adaptacji rozwiązań rynkowych do sektora publicznego.

Na różnice między zarządzaniem w sektorze publicznym i prywatnym zwracają uwagę m.in. H. G. Rainey i Y. H. Chun [2005, s. 72-102], wykorzystując wyniki badań własnych, a także tych prowadzonych przez innych autorów. Różnice te zostaną omówione w podziale na trzy następujące obszary: (1) czynniki związane $z$ otoczeniem organizacji, (2) relacje między organizacją i jej otoczeniem, a także (3) role w organizacji, jej struktury i procesy.

Czynniki związane z otoczeniem organizacji. Podstawowe w tym obszarze różnice polegają na tym, że dobra wytwarzane w sektorze publicznym często nie uczestniczą w grze rynkowej oraz że wysokość wydatkowanych środków finansowych jest zależna od dostępności funduszy publicznych. W konsekwencji tych różnic menedżerowie publiczni nie są odpowiednio motywowani do podejmowania działań na rzecz redukcji kosztów czy zwiększania efektywności prowadzonych działań. Dodatkowo, charakteryzuje ich mniejsza efektywność alokacji środków (mniejsza potrzeba brania pod uwagę preferencji klientów czy potrzeba dostosowywania podaży do popytu). Niższa efektywność menedżerów publicznych wynika również 
z tego, że wykorzystują mniej rynkowych wskaźników czy innych informacji (ceny, udział w rynku) w procesie podejmowania decyzji.

Inna różnica polega na sprawowaniu zewnętrznej kontroli przez organy władzy. W sektorze publicznym istnieją skomplikowane, rygorystyczne wymogi formalno-prawne, nakładane na menedżerów publicznych. Podlegają oni nadzorowi ze strony organów stanowiących i wykonawczych władzy publicznej oraz agencji nadzorujących i sądów. Menedżerowie publiczni posiadają mniejszą autonomię w podejmowaniu decyzji ze względu na większe ograniczenia, a także skomplikowane procedury zarządcze. Działają pod większym formalnym nadzorem administracji. Dodatkową różnicę w stosunku do sektora prywatnego stanowi fakt, że menedżerowie publiczni działają pod nadzorem niekiedy kilku różnych organów, co zdecydowanie utrudnia im pracę i rozmywa odpowiedzialność.

Wskazać należy również na obecność w sektorze publicznym zewnętrznych nacisków o charakterze politycznym. Wynika to z większej różnorodności i intensywności zewnętrznych, często nieformalnych, wpływów politycznych na podejmowane decyzje. Wymienić tu można układy polityczne, lobbing, wpływ opinii publicznej czy grup interesów, a także presję ze strony wyborców. Jednocześnie menedżerowie publiczni często potrzebują poparcia ze strony władz samorządowych, polityków, wyborców dla otrzymania funduszy czy akceptacji dla podejmowanych działań.

Relacje między organizacją i jej otoczeniem. Organizacje publiczne oraz ich menedżerowie są często angażowani w wytwarzanie dóbr publicznych, luźno związanych $\mathrm{z}$ ich działalnością, absorbując czas przy bardzo ograniczonych efektach, często takich, którymi nie są zainteresowane organizacje prywatne. W odróżnieniu od sektora prywatnego, władze publiczne mają niekiedy uprawnienia do działań wymuszających czy monopolistycznych. Dysponują unikalnymi środkami przymusu i sankcji, często są też jedynym dostarczycielem pewnych dóbr i usług. Partycypacja w konsumpcji i finansowaniu działań inicjowanych przez władze może mieć bowiem charakter obowiązkowy.

Menedżerowie publiczni działają zwykle pod większą publiczną kontrolą ze strony mediów, grup interesu czy organów nadzorujących niż menedżerowie z sektora prywatnego. Większe są również oczekiwania społeczne w stosunku do menedżerów publicznych w takich kwestiach, jak: sprawiedliwość, wrażliwość, uczciwość, otwartość czy publiczna odpowiedzialność. W sektorze publicznym działania władz mają zwykle szerszy zakres oddziaływania niż w sektorze prywatnym i większe znaczenie symboliczne. Wynika to $\mathrm{w}$ dużej mierze z potrzeby kierowania się w swoim postępowaniu kryterium interesu publicznego [Kożuch 2004, s. 89-104].

Warto zauważyć, że w ostatnich latach relacje podmiotów sektora publicznego z obywatelami czy mieszkańcami zostały wzmocnione. Obok 
typowych instytucji demokratycznych, pozwalających na utrzymywanie tych relacji i wywieranie wpływu na procesy rządzenia czy świadczenia usług publicznych, pojawiły się dobrowolne instytucje poszerzające partycypację obywateli czy mieszkańców [Frederickson 2005, s. 282-304]. Należy w tym kontekście podkreślić, że w sektorze przedsiębiorstw analogiczne relacje $\mathrm{z}$ klientami są od dawna rozwijane m.in. w ramach koncepcji marketingu relacji.

Role w organizacji, jej struktury i procesy. W obszarze tym na podkreślenie zasługują istotne różnice przy formułowaniu i realizacji celów. Jeśli w sektorze prywatnym cele te są na ogól jednoznaczne i precyzyjnie zdefiniowane, to w sektorze publicznym są one często rozmyte, wielorakie bądź ogólne. Wymieńmy tu przykładowo takie cele, jak: podnoszenie bezpieczeństwa publicznego, ochrona środowiska, wyższy standard życia, otwartość, sprawiedliwość, równość społeczna itp. Zwykle trudno ocenić realizację takich celów oraz sformułować precyzyjne kryteria ich oceny. Różnorodność celów zwiększa prawdopodobieństwo, że cele te będą ze sobą sprzeczne i mogą prowadzić do konfliktów bądź do rozwiązań kompromisowych. Trudno bowiem pogodzić takie cele, jak: efektywność i nadmierna publiczna kontrola, efektywność ze sprawiedliwością i równością społeczną, sprzeczne żądania grup wyborców itp.

Różnice dotyczą także zachowań menedżerskich, chociaż zarówno w sektorze publicznym, jak i prywatnym można wskazać wiele ich cech wspólnych. Menedżerów publicznych, w odróżnieniu od prywatnych, cechuje to, że: ich rola jest bardziej polityczna, są eksponowani ze względu na autorytet społeczny, odbywają więcej spotkań, są przedmiotem interwencji ze strony grup interesów oraz władz, stoją przed nimi większe wyzwania związane z zachowaniem równowagi pomiędzy zewnętrznymi organizacjami politycznymi a wewnętrznymi funkcjami zarządczymi. Mają oni mniejszą władzę nad swoimi podwładnymi tak ze względu na ograniczenia natury instytucjonalnej (np. systemy kadrowe służby cywilnej i pracowników samorządowych, systemy zakupów i zamówień publicznych), jak i zewnętrzne sojusze polityczne. Menedżerowie publiczni na wyższych stanowiskach niezbyt chętnie dzielą się posiadanymi uprawnieniami z podwładnymi oraz mają tendencje do ustanawiania większej liczby poziomów kontroli i zatwierdzania decyzji. Cechuje ich większa rotacja w związku $\mathrm{z}$ wyborami i politycznymi nadaniami. Niesie to ze sobą większą trudność we wdrażaniu przygotowanych wcześniej planów oraz rozwiązań innowacyjnych.

Menedżerowie oraz pracownicy organizacji publicznych dostrzegają słabszy związek pomiędzy wynikami swojej pracy a wynagrodzeniami, awansem zawodowym czy poczuciem bezpieczeństwa pracy niż pracownicy w sektorze prywatnym. Badania wykazały, że nie wpływa to w istotny sposób na poziom ich zaangażowania i wydajność pracy. Występuje tu bo- 
wiem efekt kompensacji innych motywów i bodźców, takich jak: potrzeba służby, motywy altruistyczne, poczucie wykonywania ważnej pracy oraz inne niematerialne czynniki motywujące pracowników publicznych. Ograniczone bodźce motywacyjne w organizacjach publicznych mogą wynikać $z$ większej biurokracji i biurokratycznych struktur. Badania empiryczne nie dają na ten temat jednoznacznej odpowiedzi - część z nich wskazuje na nadmierną biurokrację, podczas gdy inne tego nie potwierdzają.

Z badań wynika [Rainey, Chun 2005, s. 72-102], że menedżerowie i pracownicy publiczni, $\mathrm{w}$ porównaniu $\mathrm{z}$ zatrudnionymi w sektorze prywatnym, niżej oceniają bodźce materialne, wyżej cenią natomiast fakt zatrudnienia w służbie publicznej oraz poczucie wpływu na ważne decyzje dotyczące spraw publicznych. Te różnice pomiędzy sektorem publicznym i prywatnym pogłębiają się na wyższych poziomach $\mathrm{w}$ strukturze zarządzania. Wiele analiz wykazało porównywalny poziom zadowolenia menedżerów i pracowników w obu sektorach. Są jednak i takie dane, że respondenci z sektora publicznego skarżą się na ograniczony zakres autonomii czy nie najlepsze stosunki ze zwierzchnikami. Badania nie dały również jednoznacznej odpowiedzi na temat różnic w indywidualnej wydajności pracy $\mathrm{w}$ obu analizowanych sektorach, chociaż $\mathrm{w}$ publicznym obiegu częściej można spotkać opinię o niskiej efektywności w świadczeniu usług i niskiej innowacyjności pracowników sektora publicznego.

Reasumując powyższe rozważania, można ogólnie stwierdzić, że zarządzanie $\mathrm{w}$ sektorze publicznym i prywatnym charakteryzuje pewna specyfika, ale nie na tyle odmienna, żeby nie można było transferować między nimi doświadczeń. Podobne stanowisko reprezentuje H. Fayol, którego zdaniem różnice między analizowanymi sektorami nie są na tyle istotne, by uniemożliwić wykorzystywanie zasad zarządzania $\mathrm{z}$ sektora prywatnego w sektorze publicznym. Stoi on na stanowisku, że klasyczne zasady zarządzania są do pogodzenia z działalnością samorządów terytorialnych, realizujących funkcje państwa [Zimniewicz 2004, s. 5-13].

\subsection{Ewolucja zarządzania publicznego w kierunku otwartości organizacji}

Ocena sektora publicznego, w tym administracji rządowej i samorządowej, najczęściej jest dokonywana pod kątem sprawności i efektywności jej funkcjonowania. Efektywność ta, jak się powszechnie uważa, jest tradycyjnie niższa niż w sektorze prywatnym, stąd podejmowane próby modernizacji sektora publicznego, polegające najogólniej na adaptacji 
rozwiązań szeroko wykorzystywanych w biznesie do tego sektora. Miało to przynieść poprawę skuteczności w sektorze publicznym i zmniejszyć pod tym względem dystans do sektora prywatnego. Za przyczynę zmian należy uznać także dokonujący się w ostatnich latach wzmożony wpływ postępu technicznego i technologicznego (głównie informatyki) na zarządzanie organizacjami zarówno prywatnymi, jak i publicznymi oraz oddziaływanie tzw. rewolucji menedżerskiej.

Należy się zgodzić z A. Zalewskim, że zmiana modelu zarządzania publicznego nie jest sprawą prostą i łatwo popełnić błędy przy jej realizacji. Zaleca on przestrzeganie poniższych zasad [Zalewski 2005, s. 68]:

- nie ma gwarancji, że rozwiązania, które sprawdziły się w warunkach jednego kraju, będą odpowiednie dla innego, dlatego należy podchodzić bardzo ostrożnie do ich adaptacji;

- zmiany modelu zarządzania w sektorze publicznym powinny być dostosowane do uwarunkowań społecznych, politycznych, gospodarczych i kulturowych występujących w danym kraju,

- realizowane zmiany powinny być efektywne ekonomicznie i korzystne społecznie, a zatem ich wprowadzanie powinno być poprzedzone szczegółową analizą społecznych kosztów oraz korzyści.

Zmiana modelu zarządzania publicznego może przynieść wymierne efekty ekonomiczne. Warto w tym kontekście zacytować wypowiedź P. Druckera, którego przewidywania dla sektora publicznego są bardzo obiecujące. Jego zdaniem

w XXI wieku sektor wzrostu w krajach rozwiniętych nie będzie związany ze sferą biznesu. Najprawdopodobniej będzie nim nienastawiony na zysk sektor publiczny, w którym obecnie niezwykle potrzebne jest przeprowadzenie systematycznych, konkretnych działań, będących praktycznym zastosowaniem zasad zarządzania, co w efekcie może przynieść w ciągu krótkiego okresu bardzo dobre rezultaty [Drucker 2000, s. 8-9].

Dotychczasowe doświadczenia pokazują, że sprawne i efektywne funkcjonowanie sektora publicznego odgrywa istotną rolę w budowaniu dobrobytu społecznego. Można jedynie mieć obawy, dotyczące tempa realizowanych w tym sektorze zmian. Napotykają one zwykle na spore trudności i jeśli nawet zostaną dokonane zmiany tzw. instytucji formalnych, to proces dostosowywania do nich instytucji nieformalnych może przebiegać bardzo powoli. Oznacza to, że osiągnięcie tzw. równowagi instytucjonalnej ${ }^{1}$ może wymagać więcej czasu.

1 Równowagę instytucjonalną należy rozumieć jako dążenie do takiego zbioru instytucji oraz istniejących między nimi powiązań, które stwarzają możliwość 
Niżej przedstawiono w ujęciu chronologicznym najważniejsze modele zarządzania $\mathrm{w}$ organizacjach publicznych, które ulegały zmianie w odpowiedzi na wyzwania stawiane przed sektorem publicznym. Wyzwania te uruchamiały procesy reformowania zarządzania publicznego i przynosiły nowe zadania dla administracji publicznej. W procesie rozwoju zarządzania publicznego wyodrębniono trzy modele [Osborne 2010, s. 1-7]: biurokratyczny, nowe zarządzanie publiczne oraz współrządzenie publiczne $^{2}$. Ze względu na tematykę monografii, skupimy się głównie na prezentacji drugiego i trzeciego.

\subsubsection{Model biurokratyczny (Public Administration - PA)}

Problematyka zarządzania organizacjami publicznymi od wielu lat stanowi przedmiot rozważań wielu autorów i rozważania takie mają charakter zarówno teoretyczny, jak i koncepcyjny. Z reguły, dla oddania charakteru współczesnych przemian w zakresie zawiadywania sprawami publicznymi, autorzy nawiązują do tzw. modelu weberowskiego, nazywanego modelem idealnej biurokracji [Hausner 2008, s. 60-94], który dalej będziemy nazywać modelem biurokratycznym. Przewyższa on inne formy organizacyjne pod względem precyzji działania, stabilności, ścisłej dyscypliny i lojalności. Model weberowski, z punktu widzenia zwierzchników organizacji, zapewnia najwyższy stopień przewidywalności wyników oraz gwarantuje wysoki poziom efektywności.

Zdaniem M. Webera o racjonalności organizacji przesądzają wydzielone prawnie obszary kompetencji, w których ciągłość organizacyjna i kierowanie opierają się na bezosobowych, pisanych dokumentach, a także na ludziach, którzy przestrzegają istniejących przepisów. Ważną rolę odgrywa w tym hierarchia, wymuszająca posłuszeństwo podwładnych. W modelu hierarchicznym ważną funkcję pełni kontrola - niższe szczeble w strukturze organizacyjnej urzędu są kontrolowane przez wyższe. Władza urzędników wynika $\mathrm{z}$ zajmowanego przez nich stanowiska w hierarchii służbowej. To ono jest zasadniczym, często jedynym źródłem dochodów urzędników. Ich role organizacyjne są dopasowane do

realizacji podstawowych funkcji systemu instytucjonalnego oraz zapewniają mu względną trwałość. Dla uzyskania równowagi instytucjonalnej niezbędna jest wewnętrzna zgodność zespołu instytucji formalnych oraz nieformalnych [Załęczna 2010, s. 32-33].

2 W literaturze można spotkać również inne, wyodrębnione przez autorów modele zarządzania w sektorze publicznym. Dokonują oni podziału na starą (klasyczną, tradycyjną) administrację publiczną (old public administration) oraz zarządzanie publiczne (public management) [Izdebski 2007, s. 7-19; Wojciechowski 2007]. 
wykonywanych zadań. Kwalifikacje pracownika stanowią podstawowy warunek jego zatrudnienia i awansu zawodowego. Solidne wypełnianie obowiązków zapewnia awans oraz karierę [Samier 2005, s. 60-94].

$\mathrm{O}$ ile Weber zajmował się organizacjami administracyjnymi, to F. W. Taylor badał organizacje przemysłowe. Ten ostatni, próbując uczynić fabrykę bardziej efektywną zarówno pod względem organizacyjnym, jak i ekonomicznym dochodził do podobnych wniosków, co Weber. Obaj postrzegali organizacje formalne jako wcielenie racjonalności, którą można zwiększać poprzez traktowanie ludzi i samych organizacji jak maszyny. Jak twierdzi J. Hausner, model weberowski znalazł dodatkowe uzasadnienie w teorii F. W. Taylora, zgodnie z którą racjonalność organizacji miała zapewnić maksymalne uproszczenie i standaryzację działań [Hausner 2008, s. 14-15]. Dla W. Morawskiego [2012] biurokracja jest specyficznym typem władzy i dominacji, różniącym się korzystnie od władzy tradycyjnej i charyzmatycznej, ponieważ jest nastawiona na osiąganie jasno sformułowanych celów oraz efektywność. Zdaniem tego autora organizacja biurokratyczna nie stanowiła dla Webera uogólnienia rzeczywistości społecznej, była konstrukcją analityczno-teoretyczną, typem idealnym.

Jak model taylorowski w organizacjach gospodarczych, tak model weberowski $\mathrm{w}$ administracji publicznej $\mathrm{z}$ czasem stawał się przestarzały i w coraz mniejszym stopniu przystawał do istniejącej rzeczywistości. Już Weber dostrzegał słabe strony organizacji biurokratycznej, określając ją jako „dom niewoli” czy „żelazną klatkę”, w której rezydują „specjaliści bez ducha”. Za największe zagrożenie uważał sytuację, gdy dojdzie do powiązania biurokracji z socjalizmem, co zresztą się ziściło (socjalizm biurokratyczny) [Morawski 2012].

Wśród wad modelu weberowskiego warto wymienić takie m.in., jak [Dupuy 2002, s. 219-220]:

- rozproszenie władzy i odpowiedzialności, wynikające z wąskiej specjalizacji i indywidualizacji zadań;

- powstanie wewnątrzorganizacyjnych monopoli, co czyni organizację mało przejrzystą;

- brak współpracy pomiędzy komórkami organizacyjnymi, co powoduje dodatkowe koszty i opóźnienia decyzyjne;

- samoobsługiwanie się biurokracji, która kieruje się własnymi kryteriami oceny wyników pracy;

- eksternalizacja kosztów i brak społecznej kontroli nad działaniami biurokracji.

Te i inne wady sprawiły, że w połowie XX w. administracja publiczna nie była przystosowana do coraz bardziej złożonych procesów, jakie zachodziły w rozwiniętych krajach świata. Miało to związek z szybkim 
rozwojem rynku usług w sektorze prywatnym i wzrostem ich jakości, ze względu na nasilającą się $\mathrm{w}$ tym obszarze konkurencję. Przynosiło to wzrost oczekiwań konsumentów, którzy zaczęli formułować podobne oczekiwania wobec administracji publicznej. Zmiany dokonywały się również w samym sektorze publicznym. Powstawały nowe organizacje i stowarzyszenia, upowszechniał się dostęp obywateli do informacji, głównie za sprawą nowych środków przekazu, rosła świadomość polityczna, co w konsekwencji prowadziło do poszerzenia udziału obywateli w sprawowaniu władzy publicznej.

Pewien wpływ na zmiany $\mathrm{w}$ administracji publicznej miał również wzrost popularności liberalnych koncepcji ekonomicznych i szeroka krytyka ekonomii keynesowskiej. Krytykowano więc nadmierną rolę państwa w gospodarce, $\mathrm{w}$ tym rozbudowany sektor państwowy z olbrzymimi wydatkami publicznymi i wysokim zatrudnieniem $\mathrm{w}$ administracji publicznej. Postulowano jednocześnie ograniczenie tego sektora i dokonanie w nim głębokich reform.

Wszystkie te wady, jak również nowe uwarunkowania, sprawiły, że zarządzanie $\mathrm{w}$ administracji publicznej ulegało zmianie. Można to było zaobserwować już od zakończenia II wojny światowej, kiedy w wielu krajach zachodnich zmieniały się warunki funkcjonowania. Wprowadzany tam nowy ład społeczny implikował konieczność dostosowania do niego struktur administracyjnych. Główne jego cechy to decentralizacja państwa, która warunkowała rozwój samorządności terytorialnej. Zjawiska te zdecydowały o zmianie podejścia do współczesnego zarządzania w sektorze publicznym i pojawieniu się nowego jego modelu.

\subsubsection{Nowe zarządzanie publiczne (New Public Management - NPM)}

Szybki wzrost gospodarczy, jaki realizowano w krajach gospodarki rynkowej po II wojnie światowej, przyczynił się niewątpliwie do ukształtowania się nowego modelu zarządzania $\mathrm{w}$ sektorze publicznym, który powszechnie jest nazywany nowym zarządzaniem publicznym. Jest to model administrowania publicznego, wykorzystujący szeroko zasady gospodarki rynkowej, dlatego można spotkać w literaturze [Zawicki 2002, s. 78] takie jego określenia, jak: menedżeryzm, rynkowa administracja publiczna, menedżeryzm publiczny itp. Nie chodzi tu o pełne urynkowienie sektora publicznego, ale o stopniową adaptację podejścia menedżerskiego do zarządzania w sektorze publicznym. Sektor publiczny, jak to pokazano wcześniej, różni się od sektora prywatnego, stąd możliwości adaptacji metod i technik zarządzania menedżerskiego w sektorze publicznym będą zawsze ograniczone. 
Charakterystyki nowego zarządzania publicznego dokonamy, prezentując najważniejsze jego cechy [Hood 1991, s. 4-5]. Należy do nich z pewnością zaliczyć profesjonalizację zarządzania w sektorze publicznym. Niezbędne jest do tego nie tylko odpowiednie przygotowanie menedżerów, lecz przede wszystkim wytworzenie warunków dla efektywnego zarządzania, wyrażających się w jasnym podziale zadań i odpowiedzialności oraz przekazywaniu uprawnień do swobodnego podejmowania decyzji. W modelu tym, w odróżnieniu od poprzedniego, odchodzi się od kontroli zgodności realizowanych działań z obowiązującymi procedurami, na rzecz kontroli osiąganych rezultatów. Znajduje to zastosowanie m.in. w procesie zarządzania personelem, gdzie wysokość wynagrodzeń jest powiązana $\mathrm{z}$ rezultatami pracy.

NPM zaleca podział dużych organizacji publicznych na mniejsze jednostki organizacyjne, $z$ oddzielnym finansowaniem, pogrupowanie ich według pełnionych funkcji lub świadczonych usług. Powinny one być bardziej operatywne zarówno w relacjach wewnętrznych, jak i na zewnętrz oraz współpracować na zasadach komercyjnych. W modelu tym kładzie się nacisk na zwiększanie konkurencji w sektorze publicznym. Ma to się przejawiać m.in. w zawieraniu kontraktów terminowych i wprowadzaniu obowiązkowych procedur zamówień publicznych, czyli przetargów na dostarczanie dóbr i usług dla sektora publicznego. Wszystko to powinno prowadzić do obniżenia kosztów oraz podniesienia jakości usług publicznych.

W modelu tym eksponowana jest potrzeba wykorzystywania w sektorze publicznym sprawdzonych narzędzi zarządzania $\mathrm{z}$ sektora prywatnego. Może to polegać na wprowadzaniu bardziej elastycznych metod działania, zwłaszcza przy zatrudnianiu i wynagradzaniu pracowników. Postuluje się również podejmowanie działań zorientowanych na kreowanie pozytywnego wizerunku organizacji publicznych w społeczeństwie, co wymaga zintegrowanego komunikowania się ze społeczeństwem. Inną cechą tego modelu jest bardziej efektywne wykorzystywanie zasobów organizacji. Szczególnie preferowany jest wzrost racjonalności podejmowanych działań, co pozwoli na osiągnięcie zaplanowanych celów przy niższych kosztach. Chodzi tu m.in. o redukcję tzw. kosztów transakcyjnych, szczególnie wysokich w sektorze publicznym.

Powyższa analiza głównych elementów NPM nie pozostawia wątpliwości, że jest to, przynajmniej w pewnym zakresie, model rynkowy. Jego zakres jest zróżnicowany w poszczególnych krajach, zaś poczynione obserwacje pozwalają na sformułowanie ogólnej tezy, że im bardziej jest $\mathrm{w}$ nich rozwinięta gospodarka rynkowa, tym więcej metod i technik rynkowych można wykorzystać w sektorze użyteczności publicznej. W sektorze tym funkcjonują niezależne podmioty, takie jak przedsiębiorstwa, 
organizacje publiczne czy społeczne. Relacje między nimi są regulowane na zasadach rynkowych. Coraz szerzej wykorzystywane są elementy konkurencji, chociaż trzeba przyznać, że nie wszędzie się ona sprawdza, dlatego zmiany w tym sektorze rozpoczynane są często od testowania rozwiązań rynkowych i jeśli zdadzą egzamin, to przyjmuje się je za obowiązującą regułę [Czaputowicz 2005].

Powyższe rozważania wskazują wyraźnie na istotne różnice między NPM a modelem biurokratycznym. Najważniejsza z nich to obecność zasad gospodarki rynkowej w NPM oraz ich brak w modelu biurokratycznym. Głębokie zmiany widać również w sposobie finansowania oraz orientacji na wyniki. Tradycyjnie organizacje sektora publicznego nie musiały zajmować się pozyskiwaniem zewnętrznych środków na swoją działalność. Miały zagwarantowany budżet, adekwatny do powierzonych zadań. Model NPM odpowiada sytuacji, w której zasoby będące do dyspozycji organizacji publicznych są niedostateczne, szczególnie w stosunku do potrzeb, które rosną $\mathrm{w}$ sposób lawinowy, więc muszą być one wykorzystywane bardziej racjonalnie. Organizacje te mają często możliwość pozyskiwania zasobów na swoją działalność z innych źródeł niż budżet państwa, co wymaga dostępności zewnętrznej i wchodzenia w relacje $\mathrm{z}$ innymi podmiotami, które posiadają lub kontrolują takie zasoby. W modelu NPM organizacje publiczne powinny mieć jasno określone cele swojej działalności, podczas gdy w organizacjach tradycyjnych cele takie nie były formułowane bądź były, ale w sposób ogólny [van Helden 2000, s. 84; cyt. za: Opolski, Modzelewski 2004, s. 35].

Podsumowując tę część rozważań, można stwierdzić, że prezentowane wyżej zmiany w zarządzaniu publicznym przyniosły wzrost elastyczności w działalności organizacji publicznych, co zaowocowało lepszym ich dostosowaniem do potrzeb obywateli. Umożliwiły również poprawę efektywności prowadzonych działań, do czego przyczyniły się w znacznym stopniu procesy decentralizacji oraz pobudzanie konkurencji między usługodawcami. Funkcjonowanie organizacji publicznych na rynku wymagało większej ich otwartości, gromadzenia informacji o innych użytkownikach rynku, ich przetwarzania i wykorzystywania w bieżącej działalności. Te i inne zmiany należy więc ocenić bardzo pozytywnie, ponieważ przybliżyły sektor publiczny do bardziej efektywnego sektora prywatnego. Nie oznaczało to oczywiście pełnej niwelacji istniejących między nimi różnic, ale różnice te uległy wyraźnej redukcji.

Dokonująca się zmiana uwarunkowań sprawiła, że jeśli początkowo zauważano głównie korzystne rezultaty modelu NPM, to z czasem zaczęto dostrzegać coraz więcej jego wad czy niedoskonałości, które stały się przedmiotem jego krytyki [Ferlie, Hartley, Martin 2003, s. 1-14]. Zwracano m.in. uwagę, że wykorzystywanie mechanizmów rynkowych 
przynosiło co prawda zwiększenie sprawności organizacji publicznych oraz redukcję kosztów ich działalności, ale nie zawsze prowadziło do poprawy efektywności organizacyjnej, rozumianej jako zdolność do zaspakajania potrzeb społecznych.

Wśród wad NPM wymienia się też występowanie nierówności w dostępie do usług publicznych. Może to stanowić rezultat zróżnicowanej jakości takich usług, będący efektem ich dekoncentracji [Peters 2001, s. 330]. Krytyka NPM dotyczy także zasobów kadrowych administracji publicznej. Zauważono, że adaptacja zasad zarządzania personelem z sektora prywatnego do administracji publicznej może wpływać na morale pracowników administracji, którzy traktują swoją pracę jako służbę. Bodźce materialne mogą okazać się niewystarczające. Szczególnie może to dotyczyć pracowników funkcyjnych wyższego szczebla, którzy mogą przyrównywać swoje zarobki do tych z sektora prywatnego i w rezultacie odchodzić z sektora publicznego [Meier, Toole 2006, s. 143].

Ponadto autorzy wskazują, że nie zawsze mechanizmy rynkowe są odpowiednie dla sektora publicznego. Może to mieć związek ze skomplikowanymi relacjami między podmiotami sektora publicznego, których celem nie jest osiąganie zysku, ale zaspokajanie potrzeb obywateli [Musialik 2011, s. 500]. Mechanizmy rynkowe mogą prowadzić także do wzrostu postaw roszczeniowych obywateli. Istnieje obawa, że będą się oni stawać bardziej konsumentami niż obywatelami. Przestaną się dla nich liczyć wartości dobra wspólnego czy zanikać będą postawy obywatelskie.

Wymienione niedoskonałości NPM sprawiły, że w ostatnich latach zyskiwał popularność nowy model zarządzania publicznego nazywany współrządzeniem publicznym.

\subsubsection{Wspótrządzenie publiczne (Public Governance - PG) ${ }^{3}$}

Dynamiczne otoczenie organizacji publicznych wywiera na nie coraz większy wpływ. Dla podnoszenia efektywności organizacje te muszą coraz bardziej otwierać się na interakcje z podmiotami zewnętrznymi.

3 Genezy koncepcji Public Governance autorzy upatrują w teorii reżimów międzynarodowych [Frederickson 2005, s. 293]. Dotyczy ona politycznych aspektów stosunków międzynarodowych, gdzie podmiotami są poszczególne państwa prowadzące określoną politykę [Stone 1989]. Obserwowana w ostatnich dziesięcioleciach rosnąca różnorodność uczestników stosunków międzynarodowych i ich statusów sprawia jednak, że instytucjonalizacji zaczynają podlegać interakcje między podmiotami niepaństwowymi lub relacje na styku państwo-inne podmioty publiczne i podmioty niepubliczne. Przyniosło to w rezultacie powstanie nowych form instytucji międzynarodowych w postaci powiązań sieciowych (networks). 
Muszą nauczyć się zarządzania relacjami z partnerami publicznymi, społecznymi i prywatnymi, dążąc do wykorzystywania posiadanych przez nie zasobów na rzecz społeczeństwa. Podmioty te mają jakiś wpływ na rozwój miasta czy regionu, zaś władza terytorialna może aktywnie wykorzystywać potencjał tych podmiotów na rzecz rozwoju całego obszaru (strategie mobilizowania) [Rudolf, Karpińska 2005, s. 694].

Takie spojrzenie na organizację, szczególnie zaś na jej otwartość i potrzebę współdziałania, stanowi kluczowy element modelu Public Governance. Model ten, nazywany przez A. Rogut territorial governance,

jest procesem pionowej i poziomej koordynacji całokształtu interakcji decydentów politycznych, aparatu administracyjnego i szerszego otoczenia społecznego, odzwierciedlającym głębszą restrukturyzację państwa, jako konsekwencję: denacjonalizacji, prywatyzacji systemu politycznego i internacjonalizacji systemów politycznych [Rogut 2009, s. 6].

Denacjonalizację autorka rozumie jako przesuwanie władzy w górę - do instytucji ponadnarodowych oraz w dół - do regionów, a także w bok - do innych organizacji. Prywatyzacja systemu politycznego to przesuwanie władzy do różnych poziomów terytorialnych i funkcjonalnych. Internacjonalizacja systemów politycznych rozumiana jest tu jako włączanie zagranicznych ekspertów i instytucji do kształtowania bądź wdrażania określonych polityk.

Powyższa definicja wskazuje na nowe zadania dla administracji publicznej, która w coraz większym stopniu zaczyna dostrzegać mieszkańca, obywatela, przedsiębiorcę, czyli te podmioty, do służenia którym została powołana, których interesy reprezentuje i o których dobro powinna dbać. Wśród jej zasadniczych celów wymienić można: rozwój kapitału społecznego, budowę społeczeństwa obywatelskiego czy szerokie zaangażowanie społeczeństwa $\mathrm{w}$ przygotowywanie strategii rozwoju, a następnie w jej wdrażanie. W podobny sposób definiuje governance L. O’Toole. Jego zdaniem koncepcja ta sprzyja nawiązywaniu współpracy ośrodków władzy z interesariuszami oraz zarządzaniu sieciami [O'Toole 2003].

Elementy koncepcji governance znaleźć można na różnych szczeblach zarządzania publicznego. W dalszych rozważaniach przyjrzyjmy się sposobom oraz zakresowi jej wykorzystywania w funkcjonowaniu sektora publicznego na szczeblu międzynarodowym, krajowym, a także regionalnym i lokalnym.

Szczebel międzynarodowy. Termin governance zaczął się pojawiać już w latach 70. XX w., ale koncepcja ta nabrała znaczenia dopiero w latach 90. Warto zauważyć, że w tym pierwszym okresie wymieniana 
była głównie w kontekście działalności organizacji międzynarodowych. Uważany za jednego z prekursorów modelu PG - Bank Światowy, definiuje termin good governance jako „rozsądne zarządzanie rozwojem poprzez działania priorytetowe: budowę potencjału sektora publicznego, umacnianie rozliczalności w zakresie zarządzania finansami publicznymi, poprawę otoczenia prawnego, wspieranie przejrzystości" [Boerzel, Pamuk, Stahn 2008]. Bank ten charakteryzuje governance w kategoriach procesu wyborów i wymiany rządów, zdolności administracyjnej do formułowania i implementowania polityk publicznych i zapewniania dobrej jakości usług publicznych oraz udziału obywateli w pracach instytucji administracji publicznej, które zarządzają politykami społecznymi i gospodarczymi.

Zasługą Banku Światowego jest wprowadzanie zasady governance do działań praktycznych, które nazwano dobrym współrządzeniem (good governance). Pierwsze próby ich implementacji były związane $\mathrm{z}$ prowadzonymi przez Bank programami wsparcia dla krajów rozwijających się i miały służyć poprawie skuteczności ich funkcjonowania. $\mathrm{Z}$ czasem zasady good governance uznano nie tylko za podstawowy mechanizm poprawy skuteczności funkcjonowania tych krajów, lecz także za warunek otrzymania przez nie pomocy.

Koncepcja governance jest szeroko wykorzystywana w realizacji Programu Narodów Zjednoczonych ds. Rozwoju (UNDP), gdzie terminem tym określana jest koncepcja sprawowania władzy w sprawach gospodarczych, politycznych i administracyjnych na wszystkich szczeblach administracyjnych [www.undp.org]. Obejmuje mechanizmy, procesy, instytucje, poprzez które obywatele i ich grupy mogą artykułować własne poglądy, egzekwować prawa i realizować obowiązki czy mediować w kwestiach spornych. Agencja Stanów Zjednoczonych na rzecz Rozwoju Międzynarodowego (US AID) także popularyzuje governance, rozumiejąc ten termin jako zdolność rządu do efektywnego i wydajnego procesu zarządzania politykami publicznymi, który zmierza do wzmocnienia systemu demokratycznego m.in. poprzez partycypację obywateli.

W upowszechnianiu koncepcji governance ważną rolę odegrały instytucje Unii Europejskiej, które upatrują w niej szansę na poprawę sprawności działania swoich struktur. Przede wszystkim jednak oczekuje się większego zaangażowania społeczeństwa oraz różnych jego organizacji i instytucji w funkcjonowanie tego ugrupowania. Koncepcja ta jest coraz szerzej wykorzystywana w polityce Unii Europejskiej i pokłada się w niej spore nadzieje na wewnętrzne wzmocnienie Unii i samego procesu integracji. Wyraźne znaki, świadczące o faworyzowaniu tej teorii rządzenia można dostrzec od początku XXI w. Były przewodniczący Komisji 
Europejskiej Romano Prodi, który w 2000 r. prezentował swój program na forum Parlamentu Europejskiego, wymienił cztery strategiczne cele swojej kadencji. Wśród nich znalazła się również promocja nowych form governance.

Warto wspomnieć, że 25 lipca 2001 r. Komisja Europejska przyjęła Białą Księgę European Governance [Commission of the European Communities 2001]. W dokumencie tym postuluje się otwarcie procesu kształtowania polityki Unii Europejskiej na opinie ludzi i organizacji współtworzących oraz wdrażających polityki. Proponuje się większą otwartość i odpowiedzialność wszystkich zaangażowanych podmiotów. Powinno to umocnić przekonanie, że kraje członkowskie, działając wspólnie, są zdolne efektywniej rozwiązywać pojawiające się problemy. Dokument ten spotkał się z dużym zainteresowaniem w krajach Unii Europejskiej i wywołał ożywioną dyskusję. Formułuje się w nim pięć zasad tzw. dobrego rządzenia. Są to: otwartość (openness), partycypacja (participation), odpowiedzialność (accountability), efektywność (effectiveness), spójność (coherence).

Wymienione zasady wyraźnie nawiązują do tych, przyjętych wcześniej przez Bank Światowy. Jakość, odpowiedniość i efektywność polityk Unii Europejskiej zależy od zapewnienia szerokiej partycypacji w całym łańcuchu działań prowadzonych w ramach wspomnianych polityk - od pierwszego pomysłu do końcowego rezultatu. Partycypacja ta w ogromnej mierze zależy od rządów narodowych, które przecież same współtworzą i później wdrażają polityki unijne na terenie swojego kraju. Biała Księga zaleca dalsze odchodzenie od metody hierarchicznego sprawowania rządów oraz uzupełnianie stosowanego zestawu narzędzi zarządzania o te z zakresu tzw. prawa miękkiego.

Popularyzacja koncepcji governance przyniosła $\mathrm{w}$ rezultacie wzrost aktywności miast i regionów na arenie międzynarodowej. Coraz odważniej włączają się one w sieci współpracy, nawiązując kontakty z miastami i regionami partnerskimi z całego świata. Współpraca ta, oprócz problemów o zasadniczym znaczeniu, coraz częściej dotyczy kwestii istotnych dla węższych grup interesariuszy, z zakresu gospodarki, kultury czy edukacji. Zauważyć można rosnące uczestnictwo miast i regionów w międzynarodowych zrzeszeniach, gdzie mogą oddziaływać na decyzje dotyczące całych ugrupowań integracyjnych [Rudolf 2010a, s. 373-384]. Tworzą one ponadto własne sieci zagranicznych biur łącznikowych, co wskazuje na docenianie tego kierunku działań. Jako przykład wskazać tu można przedstawicielstwa polskich regionów w Brukseli.

Szczebel krajowy. Koncepcja governance jest stopniowo dostrzegana i rozwijana przez struktury rządowe poszczególnych krajów. Przykładem 
może tu być polskie Ministerstwo Rozwoju Regionalnego, gdzie w dokumencie pt. Koncepcja good governance - refleksje do dyskusji zapisano:

tematyka good governance to zagadnienie o ogromnym znaczeniu dla jakości rządzenia, rozumiane jako sposób i efekty sprawowania władzy, co zasadniczo sprowadza się do działań administracji. Czynnik ten decyduje w znacznej mierze o szansach rozwoju społeczno-gospodarczego poszczególnych państw. Wysoki stopień realizacji tej koncepcji przyczynia się do budowy zaufania społecznego dla działań podejmowanych przez administrację. Skuteczna realizacja zasad koncepcji good governance może się okazać kluczowa dla wzmocnienia potencjału państwa, w kierunku tworzenia przyjaznych warunków dla rozwoju społeczeństwa obywatelskiego [Ministerstwo Rozwoju Regionalnego 2008, s. 3].

Za pozytywne symptomy można uznać zlecanie przez organy rządowe badań i studiów diagnozujących działalność instytucji publicznych pod kątem praktycznej realizacji zasad good governance. Wymienić tu można przeprowadzone już badanie Polskie ministerstwa jako organizacje uczace się, będące dobrym punktem startu do wdrażania potrzebnych zmian [Olejniczaket al. 2010]. O tym, że władza zdaje sobie sprawę z roli uspołecznienia procesu podejmowania decyzji dla trwałości przyjętych rozwiązań świadczy m.in. utworzenie w roku 2010 Rady Gospodarczej przy Prezesie Rady Ministrów czy doraźnych struktur tworzonych dla rozwiązywania konkretnego problemu, wokół którego toczy się debata społeczna. Odbywające się niekiedy krajowe debaty, dotyczące ważnych problemów społecznych, są inicjowane przez ministerstwa czy agendy rządowe. Proces ten idzie niewątpliwie w dobrym kierunku, chociaż tego rodzaju inicjatywy nie są jeszcze powszechne.

Podobnie jak kraje rozwijające się, które dla uzyskania wsparcia z Banku Światowego musiały przeprowadzić szereg reform ustrojowych, tak i Polska, będąca beneficjentem funduszy unijnych, jest nakłaniana do wprowadzania zasad good governance w polityce publicznej.

Szczebel regionalny i lokalny. Dotychczasowe doświadczenia wskazują na szerokie możliwości stosowania koncepcji governance na szczeblu samorządów terytorialnych. Wydaje się, że wśród JST to właśnie samorządowy region może stać się najważniejszym obszarem wykorzystywania tej koncepcji. Przemawia za tym złożoność systemu regionalnego w porównaniu $\mathrm{z}$ powiatowym czy gminnym oraz niedoprecyzowanie przez ustawodawcę form potencjalnych relacji w układzie pionowym, między jednostkami samorządu terytorialnego w obrębie regionu. Dodatkowo, we wspomnianej Białej Księdze zwrócono uwagę na potrzebę większego dialogu Komisji Europejskiej z samorządami terytorialnymi właśnie na poziomie regionalnym i lokalnym. Komisja postulowała w niej m.in. takie 
działania, jak: ustanowienie stałego dialogu z przedstawicielami samorządów regionalnych i lokalnych, wprowadzenie większej elastyczności do ustawodawstwa wspólnotowego poprzez uwzględnianie w nim uwarunkowań regionalnych i lokalnych, tworzenie i publikowanie minimalnych standardów konsultacji polityk Unii Europejskiej oraz tworzenie struktur partnerskich w wybranych obszarach. W przypadku polityki rozwoju regionalnego czy lokalnego władza samorządowa w myśl koncepcji governance zobligowana jest do współdziałania z partnerami publicznymi, społecznymi i prywatnymi na rzecz dobra całej społeczności.

Stopniowo problematyka governance zaczęła się pojawiać również w polskiej literaturze. B. Banachowicz [2007, s. 613-622] prezentuje $\mathrm{Pu}$ blic Governance jako nowe podejście do zarządzania rozwojem lokalnym. Autorka ta bardziej akcentuje partycypacyjne podejście w zarządzaniu lokalnym, mniej uwagi poświęca natomiast sferze narzędziowej, w tym nowym instrumentom zarządzania $\mathrm{w}$ samorządach terytorialnych, wpisujących się w szeroko rozumianą koncepcję governance. Przyczyną tego jest $\mathrm{z}$ pewnością deficyt prowadzonych badań z tego zakresu, co może stanowić zachętę dla zespołów badawczych (możliwie interdyscyplinarnych) do zajęcia się tą problematyką. Zagadnienie governance w odniesieniu do samorządu terytorialnego - tym razem regionalnego, podejmuje wspominana już A. Rogut [2009, s. 5-28]. Należy zgodzić się z jej opinią, że koncepcja ta idealnie koresponduje ze specyfiką procesu innowacji. Podjęta przez nią próba identyfikacji mierników good governance jest interesująca i zasługuje na kontynuację.

Tak zdefiniowana koncepcja governance w odniesieniu do terytorium obejmuje zwykle posiadaną wiedzę oraz tworzone przez obywateli instytucje formalne i nieformalne. Oznacza również taką ewolucję zarządzania, gdzie poprzez wielostronne partnerskie relacje między podmiotami ulegają zatarciu granice między sektorem publicznym i prywatnym, a także granice wewnątrz tych sektorów. Przyjrzyjmy się zatem bliżej partnerskim relacjom w zarządzaniu publicznym.

\subsection{Partnerskie zarządzanie publiczne}

Prezentowane wyżej rozważania wskazują jednoznacznie na rosnącą rolę umiejętności kształtowania przez organizacje publiczne partnerskich relacji z podmiotami publicznymi, społecznymi i prywatnymi w procesie realizacji powierzonych im zadań. W literaturze angielskojęzycznej zjawisko takie określane jest terminem Collaborative Public Management (CPM), 
który można przetłumaczyć na język polski jako partnerskie zarządzanie publiczne $e^{4}$. Koncepcja ta, która w ostatnich latach dynamicznie się rozwija, zwłaszcza w krajach wysoko rozwiniętych, eksponuje umiejętność współdziałania władzy publicznej i menedżerów publicznych z interesariuszami instytucjonalnymi dla osiągnięcia stawianych przed nimi celów. Współdziałanie oznacza podejmowanie wspólnych wysiłków, by uzyskać wspólne korzyści. Działania takie często przekraczają granice organizacji publicznej, mają charakter wielosektorowy i są prowadzone z udziałem wielu aktorów. B. Kożuch określa współdziałanie między organizacjami jako instrument zarządzania publicznego [Kożuch 2009, s. 177-178]. Współdziałanie jest oparte na wartościach powstających w wyniku wzajemnej współpracy. McGuire definiuje partnerskie zarządzanie publiczne jako:

koncepcję opisującą proces tworzenia warunków i działania w środowisku wieloorganizacyjnym, zorientowanym na rozwiązywanie problemów, które nie mogą być rozwiązane - bądź łatwo rozwiązane - przez pojedynczą organizację [McGuire 2006, s. 33].

Część autorów twierdzi, że władza publiczna czy menedżerowie publiczni nie zawsze są głównymi aktorami w procesie współdziałania [Austin 2000; Lipnack, Stamps 1994]. Warto jednak podkreślić, że to podmioty publiczne pozostają odpowiedzialne za realizację publicznych zadań $\mathrm{i}$ to one będą $\mathrm{z}$ tego rozliczane, zatem ich zaangażowanie $\mathrm{w}$ różne formy partnerskiego współdziałania może być sposobem na wywiązanie się z tych zobowiązań. Władze samorządowe czy menedżerowie publiczni często nie sprawują kontroli nad pełnym przebiegiem określonych procesów, ale nawet wtedy są oni odpowiedzialni za rezultaty ich realizacji.

Szukając uzasadnienia dla wzrastającej roli partnerstwa w zarządzaniu organizacjami publicznymi, warto zwrócić uwagę na dwie zasadnicze tego przyczyny [McGuire 2006]. Pierwsza posiada związek ze współczesnymi przemianami społecznymi. Gdy przeanalizuje się je w ujęciu historycznym wykazują pewną prawidłowość, zgodnie z którą organizacja hierarchiczna pojawiła się i była obecna $\mathrm{w}$,erze rolnictwa”, zaś biurokracja była dominującą formą organizacyjną „ery przemysłowej”. Współcześnie, kiedy nastała „era informacji”, struktury organizacyjne stały się bardziej elastyczne i otwarte. Wzrosła liczba powiązań wewnątrz organizacji, rośnie również

4 Termin collaboration w tłumaczeniu na język polski oznacza współdziałanie bądź współpracę na zasadach partnerskich. Takie rozumienie tego terminu wynika z analizy publikacji poświęconych problematyce Collaborative Public Management. Wydaje się więc uzasadnione tłumaczenie tej frazy jako „partnerskie zarządzanie publiczne". 
liczba jej relacji z otoczeniem. Współczesny etap zmiany społecznej charakteryzuje się ogromną różnorodnością, gdzie: „władza jest rozproszona, a nie scentralizowana, gdzie zadania są raczej scalane niż dzielone na części czy wyspecjalizowane, gdzie społeczeństwo na całym świecie domaga się raczej większej wolności i indywidualizmu, niż integracji” [Agranoff, McGuire 2003, s. 23]. Dla wielu autorów jest to wiek sieci i współdziałania.

Druga z sygnalizowanych przyczyn sprowadza się do tego, że kwestie, przed którymi staje władza publiczna, a w kontekście tego opracowania - samorządowa, nie mogą być rozstrzygnięte $\mathrm{w}$ warunkach tradycyjnej biurokracji. Rozwiązywanie takich trudnych problemów, jak: rozwój gospodarczy, problemy społeczne, ochrona zdrowia czy klęski żywiołowe, wymaga innych mechanizmów, które są bardziej elastyczne i angażujące inne podmioty oraz zdolne do dostosowania się do konkretnej sytuacji. Są one szybsze w działaniu niż tradycyjne podmioty publiczne [Alter, Hage 1993]. Te trudne czy kłopotliwe sprawy nie mają rozwiązań prostych, ale $\mathrm{w}$ wielu przypadkach mają one charakter tymczasowy bądź połowiczny.

Zdaniem O’Toole [1997, s. 45-52] podejmowanie tak złożonych kwestii wymaga struktur partnerskich zarówno do wypracowania wspólnych decyzji, jak i udzielania wsparcia przy ich realizacji. Struktury takie mogą być pomocne szczególnie przy rozwiązywaniu takich problemów, gdzie społeczeństwo preferuje większy udział działań publicznych, przy mniejszym zaangażowaniu władzy publicznej. Za rozwojem partnerstwa przemawia również zyskująca w ostatnich latach większą sprawność biurokracja publiczna zarówno na poziomie rządowym, jak i na poziomie samorządów terytorialnych. Wszystko to sprawia, że mieszkańcy oczekują szerszego angażowania się organizacji publicznych w rozwiązywanie pojawiających się problemów [Goldsmith, Eggers 2004].

Można więc ogólnie stwierdzić, że partnerskie zarządzanie publiczne wydaje się wyzwaniem adekwatnym do złożoności i wagi współczesnych problemów stojących przed organizacjami publicznymi, w tym zwłaszcza terytorialnymi. Chociaż koncepcja ta zyskuje popularność dopiero od niedawna, to w krajach o rozwiniętych strukturach rynkowych i ugruntowanych zasadach demokracji jest ona szeroko wykorzystywana w sektorze publicznym, chociaż różnie jest tam nazywana [Cleveland 1973, 1985; O'Leary, Bingham 2009].

Część autorów słusznie upatruje skłonności do współdziałania, do prowadzenia szerokich dyskusji czy otwartości na kontakty zewnętrzne w uwarunkowaniach występujących w poszczególnych krajach. Mają one związek z istniejącymi tam instytucjami nieformalnymi, takimi jak tradycja, kultura, wyznania religijne itp. Ciekawych pod tym względem obserwacji dokonali Agranoff i McGuire [2003]. Ich zdaniem rozwój partnerstwa w zarządzaniu publicznym w USA stanowi rezultat istniejącego tam 
federalizmu. Obecność wielu samodzielnych jednostek, jakimi są stany, w ramach jednego kraju, w naturalny sposób zachęca do zachowań czy działań kooperacyjnych na różnych szczeblach władzy. Tezę tę potwierdzają T. E. Hall i L. J. O’Toole, prowadząc na ten temat badania empirycznie. Dotyczyły one polityki federalnej i tworzenia struktur partnerskich, integrujących różnych interesariuszy [Hall, O’Toole 2004, s. 186-207]. Widać więc, że w obszarze polityki, zagadnienia współdziałania mają długą tradycję i bogate doświadczenia, z których warto czerpać.

Partnerskie zarządzanie publiczne występuje $\mathrm{w}$ różnych konfiguracjach. Może posiadać zarówno wymiar wertykalny, gdy podmiotami współpracy są różne szczeble władzy ${ }^{5}$, jak i horyzontalny, gdy aktorzy publiczni współdziałają z prywatnymi czy społecznymi [Alter, Hage 1993]. Partnerskie zarządzanie publiczne to też współdziałanie wykraczające poza istniejące struktury, w kierunku otoczenia sieciowego [Klijn 2005, s. 257-281; O'Toole 2003, s. 234-244]. Menedżer publiczny może uczestniczyć nie tylko w zarządzaniu w ramach formalnych relacji, lecz może być równocześnie zaangażowany $\mathrm{w}$ różne układy kooperacyjne $\mathrm{z}$ innymi ośrodkami władzy publicznej, w układy międzyorganizacyjne czy międzysektorowe. Niekiedy trudno określić zasięg tego rodzaju międzyorganizacyjnej współpracy.

Czasami partnerskie zarządzanie publiczne funkcjonuje w środowisku dość sformalizowanym, kiedy ustawodawca zachęca lub nakłania organizacje do partnerskiej współpracy [Schmeider et al. 2003, s. 143158]. Zdarza się, że formalne więzi współdziałania tworzone są w ramach określonej polityki [Klijn 2008, s. 118-146]. Jednocześnie spotkać można dziedziny, w których zasady współpracy są ściśle określone i wynikają z ich specyfiki (obrona cywilna, ratownictwo medyczne itp.). Współdziałanie podejmowane w kontekście sytuacji kryzysowych jest także komponentem partnerskiego zarządzania publicznego [Drabek, McEntire 2002, s. 197-224].

\subsection{Podsumowanie}

Prowadzone rozważania pozwalają ogólnie stwierdzić, że systemy zarządzania w sektorze publicznym i prywatnym nie są tak różne, jak mogłoby się wydawać. Charakteryzują się pewną odrębnością, ale jednocześnie

5 Przykładem może tu być koncepcja multi-level governance, popularyzowana przez struktury Unii Europejskiej [Enderlein, Wälti, Zärn 2010]. 
posiadają wiele cech wspólnych. Ich specyfika posiada związek z realizowanymi celami, sposobami pozyskiwania środków do ich realizacji, z odmiennymi systemami kontroli i nadzoru itp. Oba te sektory dążą do zwiększania efektywności swoich działań, podnoszenia jakości dostarczanych produktów i usług, wzrostu zadowolenia swoich odbiorców itp. Doświadczenia sektora prywatnego, który jest pod tym względem znacznie bardziej zaawansowany, mogą być, przynajmniej w części, wykorzystane w sektorze publicznym. Oznacza to, że wiele metod i technik z sektora biznesu może znaleźć i znajduje zastosowania w organizacjach publicznych.

Możliwości wykorzystania wspomnianych metod, technik, a także doświadczeń z sektora biznesu w zarządzaniu publicznym wyraźnie rosną w miarę postępującej ewolucji modeli zarządzania. Powyższa analiza wskazuje jednoznacznie, że podstawowym kryterium zróżnicowania modeli zarządzania publicznego jest mechanizm koordynacji. Dominujący niegdyś model biurokratyczny bazował na hierarchii, mającej swoje uzasadnienie w doskonaleniu standardowych zachowań urzędników. Koordynacja rynkowa stała się natomiast mechanizmem mocno promowanym przez zwolenników NPM. Prowadziła ona do stopniowej adaptacji modelu menedżerskiego w zarządzaniu publicznym. Przyczynił się on w dużej mierze do usprawnienia zarządzania publicznego, które ze względu na uwzględnienie w nim elementów konkurencji stało się bardziej efektywne i korzystne dla beneficjentów usług publicznych. Jednak mechanizmy rynkowe w czystej postaci okazały się nie w pełni przystawać do zarządzania publicznego. Podobnie zresztą jak w sektorze prywatnym, gdzie jako alternatywa wolnej konkurencji zaczęły się rozwijać koncepcje o rosnącej roli orientacji społecznej w gospodarowaniu.

Społeczny wymiar celów organizacji publicznej oraz przemiany w otoczeniu tych organizacji stworzyły zapotrzebowanie na nowy model, bazujący na relacjach międzyorganizacyjnych czy sieciowych. Takim modelem okazał się Public Governance, którego podstawowym wyróżnikiem jest partnerstwo. Jego istotę stanowią trwałe, długookresowe związki między podmiotami, oparte na wymianie informacji i wzajemnym zaufaniu oraz na dzieleniu się wspólnymi korzyściami, a także ewentualnym ryzykiem. W tej sytuacji organizacje publiczne powinny rozwijać umiejętności kształtowania partnerskich relacji w ich wnętrzu oraz z zewnętrznymi podmiotami publicznymi, społecznymi i prywatnymi, $\mathrm{w}$ procesie realizacji powierzonych im zadań. Umiejętności te decydować bowiem będą o zakresie relacji partnerskich i generowanych dzięki nim korzyściach dla wszystkich interesariuszy organizacji publicznej. Należy jednocześnie pamiętać, że partnerstwo bazujące na wykorzystywaniu zasobów innych organizacji i ukierunkowane na generowanie wspólnego 
celu, jakim jest rozwój (tu: terytorium), wymaga zarządzania z wykorzystaniem instrumentów adekwatnych do specyfiki i złożoności zadań organizacji publicznych.

Rozwój partnerskiego zarządzania publicznego tylko w części można wytłumaczyć rosnącą elastycznością czy otwartością struktur typową dla Public Governance. Duży wpływ na rozwój takiego partnerstwa mają uwarunkowania charakterystyczne dla poszczególnych krajów. Tworzą one funkcjonujące $\mathrm{w}$ danym kraju instytucje nieformalne, takie jak: tradycja, kultura, religia itp. Mogą one zarówno sprzyjać partnerstwu, jak i mu przeciwdziałać. Można dodać, że instytucje nieformalne ulegają zmianie, ale zmiany takie trwają zwykle bardzo długo. 


\section{Rozdział 2}

\section{Marketing terytorialny w ujęciu transakcyjnym i relacyjnym}

Marketing, jako metoda działania na rynku, przeszedł długą drogę ewolucji wraz ze zmianami uwarunkowań rynkowych. Poszczególne jego etapy rozwoju w różnym stopniu mogą być atrakcyjne dla sektora publicznego. Współcześnie w sektorze prywatnym marketing jest odpowiedzialny za relacje organizacji z jej otoczeniem podmiotowym i łączy się z przekraczaniem granic organizacji. Autor stoi na stanowisku, że również organizacje publiczne, w określonym zakresie, powinny świadomie działać na rynkach oraz rywalizować $\mathrm{z}$ innymi organizacjami publicznymi i niepublicznymi. Chodzi tu zwłaszcza o terytoria, czyli miasta i regiony, których wymiar organizacyjny będziemy nazywać organizacją terytorialną (OT). Są one bowiem uczestnikami rywalizacji o mobilne czynniki wzrostu i właśnie ta przestrzeń wydaje się środowiskiem, gdzie marketing znajduje swoje zastosowanie.

Rozdział ten został poświęcony marketingowi podmiotów publicznych oraz węższej ich kategorii: jednostek samorządu terytorialnego. Rozpoczniemy go od analizy bibliometrycznej, która pozwoliła określić popularność wśród naukowców wybranych wątków badawczych. Jej celem było pokazanie dynamiki zmian, jakie dokonywały się w ostatnich 20 latach w zakresie popularności problemów badawczych związanych z rynkiem, rywalizacją, zarządzaniem publicznym, czyli szeroko rozumianym marketingiem w sektorze publicznym. Na podstawie zagranicznej literatury przedmiotu pokazano następnie kierunki rozwoju marketingu w sektorze publicznym. W dalszej części zdefiniowano marketing terytorialny odnoszony do jednostek samorządu terytorialnego oraz dokonano typologii dotychczasowych badań z tego zakresu, dzieląc dotychczasowe piśmiennictwo między „perspektywę terytorialną” a „perspektywę marketingową”. Uznano, że w dotychczasowym piśmiennictwie dominuje podejście transakcyjne. Następnie jako alternatywne przedstawiono podejście relacyjne w marketingu organizacji publicznych. Poprzedzono tę część opisem koncepcji marketingu relacji w sektorze przedsiębiorstw, z uwzględnieniem 
zyskującego tam coraz większą popularność marketingu interesariuszy. Wiele wskazuje na to, że marketing interesariuszy znajdzie nową przestrzeń do wykorzystania również $\mathrm{w}$ organizacjach terytorialnych, w ich działaniach na rynkach: inwestorów, turystów i studentów.

\subsection{Marketing w sektorze publicznym}

Marketing zaczął być użyteczny dla sektora publicznego [Proctor 2007] wraz $\mathrm{z}$ rozwojem omówionych $\mathrm{w}$ poprzednim rozdziale modeli zarządzania publicznego, opartych na rynku (NPM) [Osborne, Gaebler 1992] czy na sieciach współpracy (Public Governance) [Osborne 2010]. Upowszechnianie się tych modeli w ostatnich latach przyniosło wzrost wykorzystania szeroko pojętych narzędzi marketingowych w sektorze publicznym [Anders-Morawska, Rudolf 2015]. Warto nadmienić, że popularyzacji marketingu w tym sektorze sprzyjały takie działania mające promować urynkowienie sektora publicznego, jak: tworzenie rynków wewnętrznych, rozwój współpracy z sektorem prywatnym i społecznym czy rozwój międzyorganizacyjnego współdziałania [Zalewski 2005]. Należy jednak zaznaczyć, że działania podmiotów publicznych w tych sferach często nie są kojarzone z marketingiem, a sam termin "marketing” ma $\mathrm{w}$ środowisku pracowników organizacji publicznych negatywne konotacje, nawiązujące do technik, nie zawsze uczciwej, intensyfikacji sprzedaży w sektorze przedsiębiorstw.

\subsubsection{Sektor publiczny a rynek w badaniach naukowych}

Należy przyznać, że termin „marketing” jest różnie interpretowany przez środowisko badaczy [Niestrój 2009], a jego powszechne rozumienie nie zawsze koresponduje $\mathrm{z}$ faktycznym jego znaczeniem, jako sposobu działania organizacji na rynku. Dlatego prowadząc badania literaturowe, utożsamiono marketing $\mathrm{z}$ orientacją rynkową organizacji publicznej. Takie szerokie podejście pozwoliło wyeliminować problemy związane $\mathrm{z}$ różnorodnym definiowaniem marketingu, co na tym etapie badań uznano za nieistotne.

W świetle wcześniejszych rozważań można ogólnie stwierdzić, że $\mathrm{w}$ ostatnich latach, $\mathrm{w}$ ślad za rosnącym zakresem mechanizmu rynkowego w sektorze publicznym, rosła również popularność koncepcji marketingowych w tym sektorze. Dla bardziej precyzyjnego określenia tej 
tendencji dokonano przeglądu anglojęzycznych artykułów naukowych dostępnych w bibliometrycznych bazach danych. Badaniem objęto lata 1995-2014. Przeprowadzono analizę słów kluczowych do artykułów publikowanych w czterdziestu sześciu najwyżej notowanych czasopismach naukowych, dotyczących problematyki sektora publicznego. W tym celu wytypowano kilka terminów zbliżonych znaczeniowo do pojęć „marketing” i „rynek”, aby następnie odnaleźć je w wybranym zbiorze czasopism w badanym okresie. Poszukiwano takich pojęć, jak: efektywność (effectiveness), rynek (market), konkurencja (competition), marka (branding) oraz zarządzanie publiczne (public management) i nowe zarządzanie publiczne (NPM). Zastosowaną tu metodykę badań bibliometrycznych opisano $\mathrm{w}$ rozdziale czwartym.

W ciągu 20 lat, spośród badanych terminów autorzy najczęściej używali w słowach kluczowych takich pojęć, jak: public management oraz market, odpowiednio 463 i 461 razy. Są to średnio 23 artykuły rocznie dla każdego z tych terminów. Wynik ten świadczy o wysokiej popularności tej problematyki w literaturze naukowej dotyczącej sektora publicznego. Rezultaty badań na ten temat zostały zaprezentowane na rys. 2.1. Kilkakrotnie rzadziej użyto terminu: konkurencja (competition) (128), a na kolejnych miejscach znalazły się: budowanie marki (branding/reputation) (99), efektywność (effectiveness) (58) oraz nowe zarządzanie publiczne (new public management) (18). Ten ostatni termin był stosowany zdawkowo, w dodatku w czasopiśmie "Policy and Politics", czyli w powiązaniu z działalnością polityczną, a nie zarządzaniem. Warto jednak zauważyć, że tematyka brandingu w bazie JCR ma oddzielną kategorię poświęconą komunikowaniu się oraz że przypadki słów kluczowych z tymi terminami pojawiły się dopiero $\mathrm{w}$ ostatnich latach, co może sugerować początek wzrostowej tendencji w tym zakresie w latach następnych.

Przyjrzyjmy się obecnie dynamice występowania poszczególnych terminów w badanym okresie, zaprezentowanej na rys. 2.2. Jak wspominaliśmy, jednym z dwóch najczęściej wymienianych w słowach kluczowych terminów był market. Aż do 2006 r. jego częstość utrzymywała się na względnie stałym poziomie i dopiero rok 2007 przyniósł jego trzykrotny wzrost $\mathrm{w}$ stosunku do roku poprzedniego. W następnych latach, po chwilowym spadku, jego częstotliwość nadal rosła, nie osiągnęła jednak poziomu z $2007 \mathrm{r}$. W ostatnich latach częstość podejmowania przez autorów problematyki rynku w powiązaniu z sektorem publicznym zaczęła nieznacznie maleć. W przypadku terminu public management optimum wystąpiło w 2010 r., zaś w kolejnych latach częstość ta ustabilizowała się na nieco niższym poziomie, $\mathrm{z}$ lekką tendencją spadkową, co warto powiązać ze wzrostem popularności problematyki związanej z relacjami, o czym będzie mowa w rozdziale trzecim. 
Termin public management pojawiał się najczęściej w słowach kluczowych tekstów opublikowanych w czasopismach dotyczących administracji publicznej, np. w "International Review of Administrative Sciences" (18,14\%), "Public Administration" (13,39\%), "Public Administration and Development" (10,15\%). Natomiast termin market dominował w periodykach zawierających teksty o polityce publicznej: środowiskowej ("Climate Policy" - 13,23\%) i społecznej ("Journal of European Social Policy" - 11,50\%, "Journal of Social Policy" - 8,46\%).

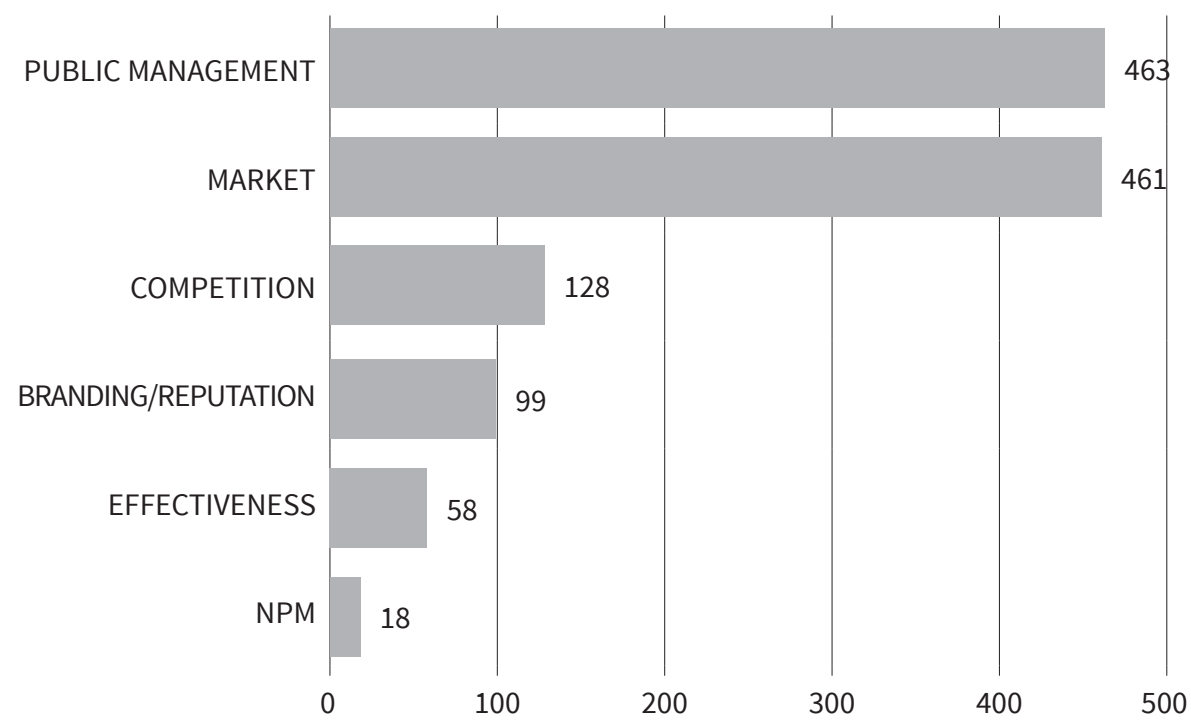

Rys. 2.1. Łączna liczba badanych terminów związanych z rynkiem użytych w słowach kluczowych artykułów naukowych badanego zbioru czasopism z zakresu sektora publicznego w latach 1995-2014

Źródło: opracowanie własne na podstawie bibliometrycznych baz danych: Journal Citation Report (Web of Science) oraz SCOPUS (ELSEVIER).

Termin effectiveness pojawiał się niemal ośmiokrotnie rzadziej niż market czy public management. Należy jednak podkreślić, że tylko dwa pojęcia (effectiveness, branding/reputation) spośród wszystkich badanych posiadały w ostatnich kilku latach tendencję wzrostową (rys. 2.2). Można stąd wyciągnąć wniosek, że tematyka ta staje się coraz bardziej popularna. Warto jednak zauważyć, że termin effectiveness może być kojarzony zarówno z konkurowaniem na rynku, jak i może być używany jako jedna z zasad modelu Public Governance, który opiera się na podejściu relacyjnym. Wzrost jego popularności w ostatnich latach może wskazywać na częstsze jego używanie w kontekście Public Governance. 


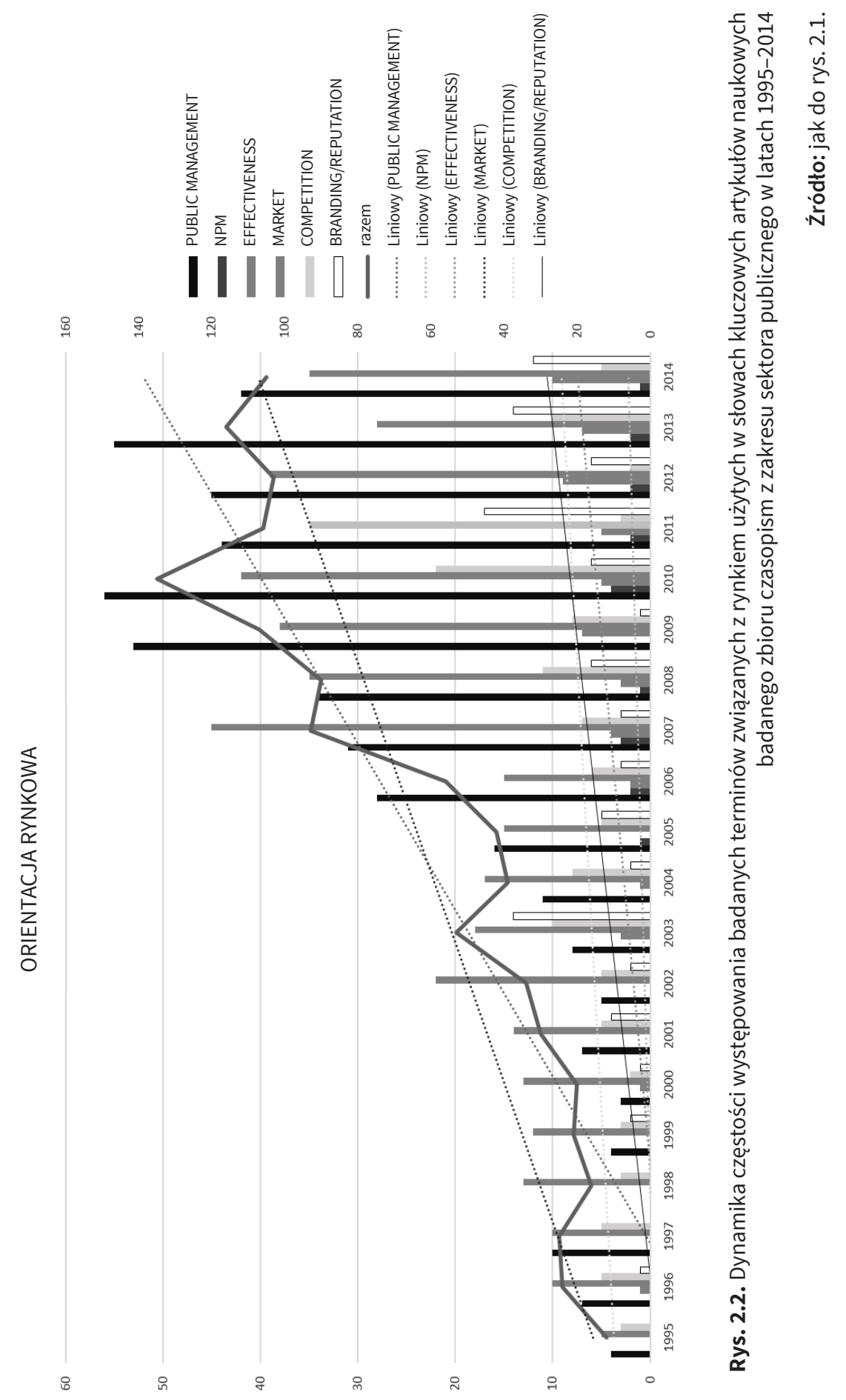




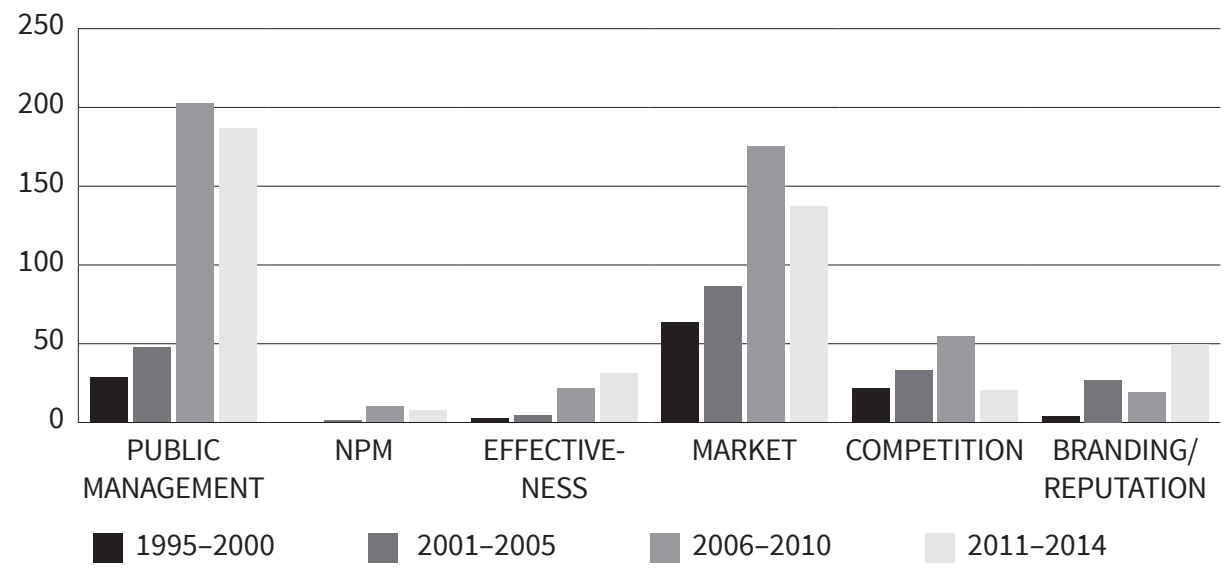

Rys. 2.3. Dynamika wzrostu częstości występowania terminów związanych z rynkiem w słowach kluczowych artykułów naukowych badanego zbioru czasopism z zakresu sektora publicznego w latach 1995-2014 z podziałem na cztery okresy

Źródto: jak do rys. 2.1.

Dodatkowe zestawienia dotyczące popularności omawianych terminów zamieszczono w załącznikach. W załączniku 2.1 zaprezentowano trendy częstości występowania badanych terminów w słowach kluczowych artykułów naukowych $\mathrm{w}$ badanym zbiorze czasopism $\mathrm{w}$ latach 1995-2014. Natomiast załącznik 2.2 zawiera zestawienie dotyczące częstości występowania terminów w słowach kluczowych artykułów w czterech pięcioletnich okresach. Dokonany podział na cztery pięcioletnie okresy pozwala dostrzec nowe prawidłowości. O ile w dwóch ostatnich okresach najczęściej w słowach kluczowych pojawiał się termin public management, to wcześniej najczęściej występował termin market. Natomiast termin competition notował tendencję wzrostową do przedziału 2006-2010, ale już w ostatnim z badanych przedziałów nastąpiło zahamowanie tej tendencji, a nawet niewielki jej spadek.

Kończąc rozważania na temat popularności podejmowanej przez badaczy problematyki funkcjonowania rynku w sektorze publicznym, warto podkreślić, że autorami analizowanych artykułów są głównie naukowcy ze Stanów Zjednoczonych, krajów Europy Zachodniej oraz z kilku państw z innych kontynentów, gdzie procesy usprawniania sektora publicznego są bardzo zaawansowane (takich jak Australia czy Nowa Zelandia). W ostatnich latach nieco rzadziej podejmowali oni w swoich tekstach dotyczących funkcjonowania sektora publicznego wyżej wymienione terminy bezpośrednio nawiązujące do orientacji rynkowej. Zanotowano natomiast pewne tendencje wzrostowe 
w przypadku takich terminów, jak: effectiveness i branding/reputation. Są to pojęcia, które mają swoje znaczenie nie tylko w orientacji rynkowej, lecz także relacyjnej, co sugeruje, że właśnie w tym ostatnim kontekście mogły być stosowane. Opis wyników podobnych badań, ale w odniesieniu do orientacji relacyjnej organizacji publicznej, przedstawiono w rozdziale trzecim.

\subsubsection{Kierunki rozwoju marketingu w sektorze publicznym}

Prekursorami wykorzystania marketingu w sektorze publicznym byli P. Kotler i S. Levy [1969, s. 10-15], którzy, publikując artykuł pt. Broadening the concept of marketing w "Journal of Marketing", poszerzyli zakres wykorzystywania koncepcji dotychczas zarezerwowanej dla przedsiębiorstw o podmioty z innych sektorów. Trzeba przyznać, że właśnie w USA pojawiały się pierwsze opracowania, wiążące marketing nie tylko z funkcjonowaniem przedsiębiorstw, lecz także z tworzeniem i realizacją polityk publicznych [Wilkie, Gardner 1974, s. 38-47; El-Ansary, Kramer 1973, s. 1-7; Bloom, Dholakia 1973, s. 63-67] oraz z usługami publicznymi [Zaltman, Vertinsky 1971, s. 19-27]. Wydaje się, że ukierunkowanie wysiłków podmiotów publicznych na takie działania, jak: poprawa jakości życia mieszkańców, wyrównywanie szans jednostek i grup czy wzbogacanie kapitału społecznego terytorium, stanowi naturalną przestrzeń dla wykorzystywania marketingu w sektorze publicznym.

Adaptacja koncepcji marketingowych w sektorze publicznym odbywała się początkowo na pewnych ogólnych zasadach, w stosunku do organizacji publicznych bądź pozarządowych [Kotler, Levy 1969; Burton 1999; Chapman, Cowdell 1998; Graham 1995]. Stopniowo jednak można było zauważyć tendencję do rozwoju jego koncepcji branżowych (terytoria, zdrowie publiczne, organizacje non-profit itp.) [Bean, Hussey 1997; Moullin 2002; Baker 1995]. Widać tu pewne podobieństwo do sektora prywatnego, gdzie wykształciły się m.in. ujęcia branżowe marketingu dotyczące ubezpieczeń, banków itp. Różnice między tymi sektorami sprowadzają się głównie do długości okresu, kiedy pojawiły się ujęcia branżowe marketingu. W sektorze prywatnym trwało to znacznie dłużej niż w sektorze publicznym, który wykorzystywał istniejące już doświadczenia sektora prywatnego [Gregor 2006].

Zdaniem wielu autorów marketing w sektorze publicznym służy m.in. do komunikowania się władz publicznych czy organizacji publicznych ze społeczeństwem, grupami obywateli czy mieszkańcami. Pomocny jest tu 
szczególnie tzw. marketing społeczny (social marketing)ㄹ, który polega na wykorzystywaniu narzędzi i technik marketingowych do wywierania wpływu na pożądane zachowania społeczne. Działania takie mają na celu poprawę bezpieczeństwa, większą dbałość o środowisko lub poprawę zdrowia i kondycji fizycznej mieszkańców. Prowadzą je szeroko rozumiane organizacje użyteczności publicznej i są to zarówno organizacje sektora publicznego, jak i podmioty świadczące usługi publiczne, realizowane w ramach polityki państwa. Na podkreślenie zasługuje wzrost pozycji organizacji pozarządowych, których działania są często bardziej skuteczne niż podmiotów prywatnych.

Do popularyzacji marketingu w sektorze publicznym przyczyniła się niewątpliwie książka T. Proctora, w której zidentyfikowano wiele obszarów wykorzystania marketingu w tym właśnie sektorze. W skazuje on na możliwość adaptacji narzędzi marketingowych wypracowanych w sektorze przedsiębiorstw, zwłaszcza przedsiębiorstw sektora usług, do organizacji publicznych. Autor ten zaznacza, że chociaż w sektorze publicznym niekiedy brakuje „rynku”, to mogą go zastąpić relacje z interesariuszami poprzez wywieranie wpływu na osoby odpowiedzialne za efektywność organizacji publicznych [Proctor 2007, s. 1-7].

Pozytywną rolę marketingu $\mathrm{w}$ sektorze publicznym dostrzega też H. Buurma, którego zdaniem marketing może się okazać przydatny we wdrażaniu tych polityk, w których udział obywateli jest kluczowy $\mathrm{w}$ generowaniu społecznej efektywności. Teza ta jest bardzo interesująca i znajdzie odzwierciedlenie w dalszych rozważaniach [Buurma 2001, s. 1287-1300]

Inaczej postrzega rolę marketingu $\mathrm{w}$ organizacjach publicznych S. Burton, sprowadzając ją głównie do funkcji promocyjnych, co uznać można za nieuzasadnione zawężenie. Na uwagę zasługuje natomiast jej teza o kluczowej roli interesariuszy organizacji publicznych w rozwoju tej koncepcji marketingu. W modelu marketingu dla sektora publicznego (rys. 2.4), wyodrębnia ona takie następujące po sobie etapy, jak: (1) analiza interesariuszy, (2) strategia świadczenia usług publicznych, (3) strategia wywierania wpływu na interesariuszy [Burton 1999, s. 378-380].

1 Termin „marketing społeczny” po raz pierwszy wprowadzili do literatury P. Kotler i G. Zaltman [1971]. W kolejnych publikacjach Kotler i jego współpracownicy rozwinęli tę koncepcję, formułując szereg strategii marketingowych adresowanych już nie tylko do organów władzy w procesie tworzenia polityk, lecz także do podmiotów nienastawionych na zysk, których rola, zwłaszcza w procesie tworzenia polityk, zaczęła rosnąć [Kotler 1975]. 


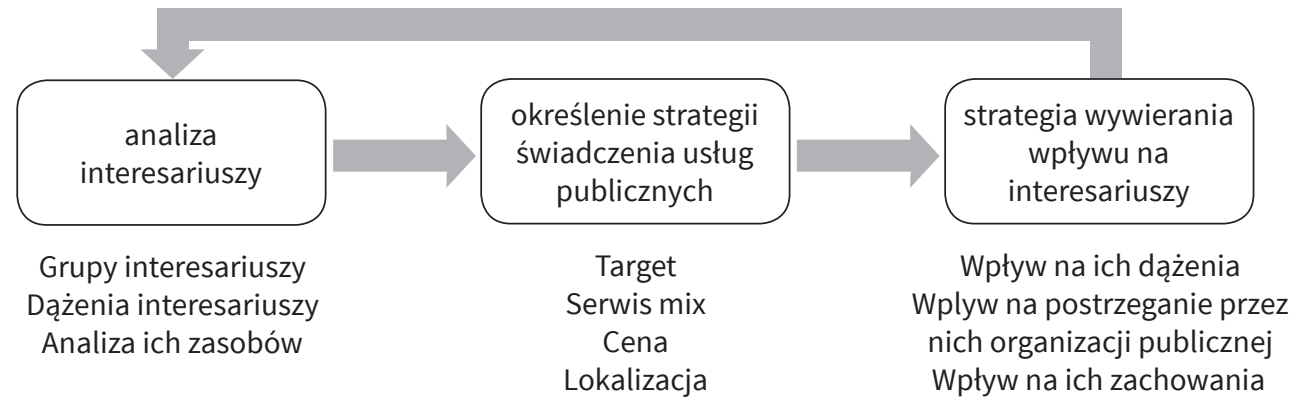

Rys. 2.4. Model marketingu w sektorze publicznym Źródto: [Burton 1999, s. 378].

Jej stwierdzenie, że koncepcja marketingu powinna być dopasowana do polityki publicznej tak, aby opierała się na wymianie pomiędzy władzą a obywatelem, budzi już jednak pewne wątpliwości. Obywatel bowiem w ogromnej większości nie jest podmiotem mobilnym, a tylko taka pełna mobilność dawałaby mu realny wybór, skutkujący zmianą miejsca zamieszkania przy niezadowoleniu z miejskiej oferty. Zatem podążanie $\mathrm{w}$ takim kierunku w procesie poszerzania przestrzeni dla marketingu wydaje się mało obiecujące.

Warto podkreślić, że do końca lat 90. XX w. marketing wykorzystywany w organizacjach sektora publicznego bazował na ujęciu klasycznym, podkreślającym transakcyjny charakter więzi z klientem oraz bezpośrednią konkurencję. Osborne et al. zwracają uwagę, że ten rodzaj marketingu nie jest zdolny dostosować się do prowadzonej polityki i uwzględniać złożoność sektora publicznego [Osborne, McLaughlin, Chew 2010, s. 185-199]. Uważają, że marketing transakcyjny stanowi nieodpowiednią podstawę metodologiczną do rozwijania marketingu $\mathrm{w}$ organizacjach publicznych. Ewolucja sektora publicznego wywołana dynamicznymi przemianami otoczenia oraz zmiany w działaniach przedsiębiorstw (wzrost roli strategicznych i operacyjnych narzędzi kooperacji i współpracy) skłaniają organizacje publiczne do aktywnego poszukiwania nowych metod i instrumentów działania.

W dalszych rozważaniach nieco zawęzimy zakres prowadzonych analiz, ograniczając je do jednostek samorządu terytorialnego, które w wymiarze organizacyjnym będą traktowane jako organizacje terytorialne. $\mathrm{W}$ przekonaniu autora te właśnie organizacje w największym stopniu są „narażone” na funkcjonowanie rynku, a równocześnie ze względu na swobodę, jaką im stworzono, mają najszersze możliwości budowania relacji z interesariuszami instytucjonalnymi z ich otoczenia. 


\subsection{Geneza i rozwój marketingu terytorialnego}

Marketing terytorialny (territorial marketing) jest koncepcją, która rozwijała się równolegle w USA i w Europie w latach 80. i 90. XX w. Większość autorów wiąże jej pojawienie się z kryzysem lat 70., kiedy kłopoty gospodarcze wielu miast i regionów na świecie wymusiły na ich władzach podejmowanie działań naprawczych, adekwatnych do zmieniających się warunków otoczenia. Nasiliły się zmiany dotyczące struktury gospodarki, przyspieszeniu uległy procesy dezindustrializacji, zwiększyła się mobilność przedsiębiorstw oraz czynników produkcji itp. To wszystko przyczyniło się do nasilania się konkurencji pomiędzy terytoriami.

Marketing terytorialny można zdefiniować jako: „proces zarządczy ukierunkowany na maksymalizację wartości dla udziałowców (mieszkańców). Maksymalizacja wartości jest możliwa dzięki zaangażowaniu w procesy marketingowe interesariuszy instytucjonalnych zgodnie z zasadami dobrego współrządzenia” [Anders-Morawska, Rudolf 2015, s. 135].

\subsubsection{Geneza marketingu terytorialnego}

Pierwsze symptomy aktywności terytoriów dotyczą działań promocyjnych, ukierunkowanych na pozyskiwanie potencjalnie wartościowych użytkowników terytorium. Odnaleźć tu można analogię do marketingu w sektorze przedsiębiorstw, gdzie koncepcję marketingową poprzedzała koncepcja sprzedaży. W przypadku amerykańskich miast czy całych stanów chodziło o zainteresowanie potencjalnych mieszkańców, inwestorów czy turystów nową lub odnowioną ofertą terytorialną [Ward 1998]. Zatem już przeszło 100 lat temu w USA realizowano kampanie zorientowane na przyciąganie turystów (Selling the resort), nowych mieszkańców przedmieść (Selling the Suburb), inwestorów do miast rozwijających działalność przemysłową (Selling the Industrial Town) oraz na promocję dla różnych użytkowników miast poprzemysłowych (Selling the Post-Industrial City).

Działania te weszły na wyższy, bardziej złożony poziom dopiero w końcu XX w., kiedy zaczęto tworzyć ofertę terytoriów pod kątem potrzeb różnych grup ich użytkowników. W tym kontekście duży wkład w rozwój marketingu terytorialnego wniósł $\mathrm{Ph}$. Kotler oraz jego zespół. Opublikowali oni trzy pozycje książkowe poświęcone marketingowi miejsc (marketing places), kierowane najpierw na rynek amerykański [Kotler et al. 1993], a następnie europejski i azjatycki [Kotler et al. 1999, 
2002]. Adaptowali oni klasyczną koncepcję marketingu do podmiotów terytorialnych, którymi w USA są stany i miasta.

Wśród autorów dominuje szerokie ujęcie marketingu terytorialnego. Działania marketingowe mogą się bowiem okazać przydatne w: tworzeniu własnego wizerunku, budowie relacji między podmiotami oraz miejscem, w którym one funkcjonują, wykorzystywaniu i pozyskiwaniu zasobów itp. Ze względu na wielość podmiotów funkcjonujących na danym terenie oraz zróżnicowany charakter interesariuszy, a także liczne ośrodki decyzyjne orientacja marketingowa w marketingu terytorialnym musi uwzględniać koordynację działań tych podmiotów, integrować ich dla realizacji wspólnych celów nakierowanych na rozwój terytorium [Duczkowska-Piasecka 2013, s. 60].

Ostatnie trzy dekady przyniosły dynamiczny rozwój koncepcji marketingowych w odniesieniu do terytorium, zwłaszcza w Stanach Zjednoczonych i Europie Zachodniej. Poświęconą tej problematyce literaturę należy jednak ocenić krytycznie. Zauważyć bowiem można, że ukazujące się na ten temat publikacje mają niejasne korzenie teoretyczne lub są ich pozbawione, zaś sam termin „marketing terytorialny” jest bardzo różnie rozumiany przez autorów. Sklasyfikowanie tej literatury w jednorodne grupy jest więc trudne. Posiada to z pewnością związek z interdyscyplinarnym charakterem koncepcji marketingu terytorialnego, ale także z faktem, że wielu autorów posługuje się pojęciami z obszaru marketingu terytorialnego bez głębszej refleksji metodologicznej.

Marketing terytorialny jest bowiem kojarzony przez większość badaczy z działaniami zorientowanymi na zewnątrz, podejmowanymi $\mathrm{w}$ celu zwiększenia atrakcyjności i konkurencyjności miejsca. Ma na to wpływ wykorzystywanie przez autorów dorobku marketingu z sektora przedsiębiorstw i stosowanie go w odniesieniu do terytoriów. W rezultacie jedni traktują go jako element procesu zarządzania [Kotler et al. 1999; Rainisto 2003], podczas gdy inni - jako sposób lepszego zaspakajania potrzeb czy usprawnienia dialogu z mieszkańcami [Ashworth, Voogd 1988, s. 65-79; Ashworth, Voogd 1990; Ashworth, Kavaratzis 2008, s. 150-165; Olsson, Berglund 2009].

\subsubsection{Typologia podejść badawczych w marketingu terytorialnym}

Należy zaznaczyć, że już w końcu lat 90. XX w. część badaczy dokonywała podsumowań czy przeglądów dotychczasowego piśmiennictwa z zakresu marketingu terytorialnego. Dochodzą oni do wniosku, że wykorzystywane tam terminy (place marketing, city marketing itp.) cechuje 
wieloznaczność. Dodatkowo, ze względu na fakt, że problematykę marketingu miejsc podejmują specjaliści z różnych dziedzin, pojęcie to jest interpretowane w sposób dość dowolny. W tym kontekście warto zauważyć, że wielu autorów piszących na ten temat to przedstawiciele nauk geograficznych. Nie do końca rozumieją oni istotę zarządzania marketingowego terytorium, zaś w swoich badaniach koncentrują się na czynnikach rozwoju (terytorium), znaczeniu i efektach spektakularnych miejskich projektów oraz promocji terytorium [Gold, Ward 1994; Eisinger 2000, s. 316-333].

Krytycznie do wczesnych prac sygnowanych terminem place marketing odnosi się J. G. Bourchert [1994], który już na początku lat 90. XX w. dokonał przeglądu literatury z tego zakresu. Zwraca on uwagę, że większość analiz praktycznie nie nawiązuje do istoty marketingu jako orientacji rynkowej organizacji, ale rozwija aspekty z zakresu komunikowania się miejsca. Warto zauważyć, że takie rozumienie marketingu w sektorze przedsiębiorstw dominowało w ramach orientacji sprzedażowej w połowie XX w. Autor ten wskazuje na potrzebę dokonania rozróżnienia marketingu terytorialnego na podstawie różnych perspektyw naukowych. Widzi również konieczność posługiwania się bardziej konkretną terminologią, ułatwiającą porównywalność badań naukowych. Do podobnych wniosków doszli również inni badacze analizujący piśmiennictwo dotyczące marketingu terytorialnego [Short, Kim 1999; Ward 1998; Millington, Young, Lever 1997, s. 16-42].

Bazując na wspomnianych wyżej badaniach, dotyczących piśmiennictwa $\mathrm{z}$ zakresu marketingu terytorialnego, Bourchert wyodrębnił trzy obszary: promocję miejsca, sprzedaż miejsca oraz miejskie strategie marketingowe. Podział ten okazał się jednak mało konkretny, ponieważ nie określał jasnych granic tych, w końcu zbliżonych do siebie, kategorii. Jako przykład podać można kampanię wizerunkową miasta, którą można umiejscowić w każdym z wyżej wymienionych obszarów. Przedstawiona klasyfikacja nie spełnia więc warunków klarowności i wyłączności, co przesądziło o tym, że jest w niewielkim stopniu przydatna.

W tej sytuacji autor podjął próbę opracowania własnej klasyfikacji dotychczasowej literatury naukowej z zakresu marketingu terytorialnego. Analiza tych prac pozwala wyodrębnić dwa charakterystyczne nurty, sygnalizowane już we wstępie do niniejszej monografii. Pierwszy z nich jest nacechowany przestrzennym wymiarem marketingu terytorialnego $i$ jest reprezentowany przez urbanistów, geografów społeczno-ekonomicznych oraz planistów przestrzennych. Badacze ci starają się adaptować koncepcję marketingu do procesów planowania publicznego i rozwoju terytorialnego. Do nurtu tego zakwalifikować więc można literaturę poświęconą rozwojowi lokalnemu i regionalnemu, a zwłaszcza kreowaniu konkurencyjności przestrzennej poprzez dążenie do delokalizacji czynników rozwoju. 
Ten nurt marketingu terytorialnego rozwijany jest też przez urbanistów, w kontekście uspołecznienia procesów decyzyjnych w zakresie problemów lokalnych i regionalnych. Tacy autorzy, jak Ashworth i Voogd [1990] postulują usprawnienie planowania przestrzennego poprzez konsultacje z udziałem szerokiej rzeszy użytkowników przestrzeni. Promują oni marketing terytorialny jako sposób myślenia zarządzających obiektami i przestrzenią publiczną, zorientowany na uwzględnianie potrzeb mieszkańców. Część autorów zwraca jednak uwagę, że prowadzone działania powinny $\mathrm{w}$ większym stopniu uwzględniać potrzeby grup rezydujących w mieście niż potrzeby potencjalnych użytkowników, których miasto miałoby dopiero pozyskiwać [Olsson, Berlund 2009]. W ramach pierwszego z tych nurtów mieści się też rozwój przedsiębiorczości miejskiej (urban enterpreneurialism), gdzie podkreśla się potrzebę wzmacniania kapitału społecznego i lokalnej przedsiębiorczości, co przekłada się na procesy rozwojowe.

Drugi ze wspomnianych nurtów jest reprezentowany przez autorów zajmujących się marketingiem przedsiębiorstw, zarządzaniem marketingowym, czy budowaniem marki [Kotler et al. 1993, 1999, 2002; Lucarelli, Berg 2011, s. 9-27]. Postrzegają oni marketing terytorialny przez pryzmat zarządzania i marketingu w sektorze prywatnym. W ich pracach nie docenia się specyfiki terytorium, a zwłaszcza podejść teoretycznych związanych z rozwojem przestrzennym. Wiele ich analiz dotyczy marki terytorialnej, która traktowana jest tam jako element zarządzania strategicznego terytorium.

Można tu nawet zaobserwować pewną prawidłowość, a mianowicie, że o ile badacze zagraniczni podejmujący problematykę marketingu terytorialnego dominują w pierwszym nurcie, podkreślając jego wymiar terytorialny, o tyle w przypadku badań krajowych większość badaczy identyfikuje się z nurtem typowo marketingowym, z mocnym akcentem na procesy komunikowania się [Szromnik 2012; Florek 2014]. Geneza tego ostatniego nurtu jest spójna $\mathrm{z}$ ewolucją marketingu $\mathrm{w}$ sektorze przedsiębiorstw i dotyczy procesu promocji, a następnie komunikowania się terytorium. Ostatnie lata przyniosły natomiast znaczny wzrost zainteresowania problematyką marki terytorialnej. Jest ona traktowana nie tylko jako element promocji, lecz także jako strategiczne podejście do komunikowania się terytorium.

W tab. 2.1 dokonano zestawienia omówionych wyżej nurtów, określając je jako: „perspektywę terytorialną" i „perspektywę marketingową”. Zawarto w niej charakterystyczne dla każdej z wymienionych perspektyw pytania badawcze, które pozwalają na bliższe określenie zakresu danej perspektywy, na określenie problemów badawczych itp. Należy jednak zauważyć, że część autorów próbuje łączyć te dwa ujęcia, co można określić jako przejaw interdyscyplinarności marketingu terytorialnego. Sprawia to, że np. problematykę marki terytorialnej podejmują nie tylko badacze związani 
z marketingiem czy zarządzaniem, lecz także geografowie czy urbaniści, dzięki czemu omawiany marketing staje się jeszcze bardziej interesujący. W dolnej części tab. 2.1 wymieniono typowych reprezentantów (badaczy) zajmujących się problematyką dotyczącą danej perspektywy.

Tabela 2.1. Perspektywy badań nad marketingiem terytorialnym

\begin{tabular}{|c|c|}
\hline Perspektywa terytorialna & Perspektywa marketingowa \\
\hline $\begin{array}{l}\text { Jak konkurować w sytuacji kryzysu? } \\
\text { Jak odnaleźć się w zmieniającym się } \\
\text { otoczeniu? } \\
\text { Jak podnosić atrakcyjność terytorium? } \\
\text { Jak przekonywać adresatów zewnętrznych } \\
\text { o przewadze konkurencyjnej terytorium? } \\
\text { Jak „sprzedać” terytorium? } \\
\text { Co oznacza koncepcja marketingowa } \\
\text { w procesach planowania terytorialnego? }\end{array}$ & $\begin{array}{l}\text { Jakie są jej rynki docelowe organizacji? } \\
\text { Jakich interesariuszy ma wokół siebie } \\
\text { organizacja? } \\
\text { Jak adaptować koncepcję marketingu do } \\
\text { terytoriów? } \\
\text { Jakie instrumenty marketingowe sprzyjają } \\
\text { wdrażaniu strategicznych planów } \\
\text { w praktyce? } \\
\text { Jak kształtować relacje międzynarodowe } \\
\text { miasta i regionu? }\end{array}$ \\
\hline $\begin{array}{l}\text { Badacze nauk geograficznych, urbaniści, } \\
\text { planiści przestrzenni, zajmujący się polityką } \\
\text { publiczną }\end{array}$ & $\begin{array}{l}\text { Badacze zajmujący się marketingiem, } \\
\text { zarządzaniem strategicznym, zarządzaniem } \\
\text { marketingowym }\end{array}$ \\
\hline
\end{tabular}

Źródło: opracowanie własne z wykorzystaniem: [Berglund, Olsson 2010].

Autor stara się łączyć w swoich badaniach obie perspektywy. Dużo uwagi poświęca identyfikacji kluczowych interesariuszy instytucjonalnych dla organizacji terytorialnej, aby następnie skoncentrować się na wybranej relacji obserwowanej przez pryzmat realizowanych przez region procesów marketingowych zorientowanych na przyciąganie mobilnych czynników wspierających rozwój terytorialny.

\subsubsection{Rozwój marketingu terytorialnego w Polsce}

Realizowany w Polsce proces rozwoju marketingu terytorialnego należy w ostatnich latach do niezwykle dynamicznych, co ma związek prawdopodobnie $\mathrm{z}$ jego wykorzystywaniem $\mathrm{w}$ praktycznych działaniach samorządów terytorialnych. Początkowo (1995-2000) publikacje na jego temat miały charakter ogólny lub teoretyczny. Nie było jeszcze wtedy zbyt wielu interesujących przykładów do zaprezentowania czy to $\mathrm{w}$ charakterze dobrych praktyk, czy też jako nieudanych przedsięwzięć, poddanych krytycznej analizie. Do pozytywnych zja- 
wisk tego okresu można zaliczyć fakt, że autorzy starali się twórczo odnosić wyzwania marketingowe do dziedzin nauki, którymi się zajmują [Frankowski 2000]. Pozytywnie należy ocenić również dopraszanie zagranicznych autorów do realizowanych w Polsce programów, co skutkowało rzuceniem nowego światła na problemy rozwoju terytoriów [Domański 1997].

Do wspominanego wyżej dynamicznego rozwoju marketingu w Polsce przyczyniają się niewątpliwie liczne publikacje na ten temat. Są to zarówno prace naukowe [Markowski 2001; Kauf 2009], jak i popularnonaukowe [Florek, Janiszewska 2008; Łazarko, Niedzielska 2011], popularyzujące dobre praktyki i wzorcowe procedury, dotyczące marketingu terytorialnego. Powstają liczne, bogato ilustrowane podręczniki, tworzone zwłaszcza przez praktyków, na co dzień stykających się z marketingowymi problemami polskich miast [Proszkowska-Sala, Florek 2010; Pogorzelski 2012; Stępkowski 2015]. Szczególnie dotyczy to wydawnictw edukacyjnych, na które jest nadspodziewanie wysoki popyt. Świadczą o tym aż cztery wydania książki A. Szromnika w ciągu sześciu lat [Szromnik 2007, 2008, 2010,2012] oraz pojawianie się wciąż nowych podręczników². Jest to po części efekt wprowadzania do programów studiów wyższych przedmiotu „marketing terytorialny” na takich kierunkach, jak: gospodarka lokalna, gospodarka przestrzenna, zarządzanie publiczne czy marketing i zarządzanie.

Ponadto można zaobserwować tendencję do rozwijania problematyki marketingu terytorialnego $\mathrm{w}$ ujęciu sektorowym, czego wyrazem są publikacje odnoszące się do przyciągania inwestorów, roli uczelni wyższych $\mathrm{w}$ tym procesie czy roli wizerunku miasta $\mathrm{w}$ procesie przyciągania turystów [Jarczewski 2012; Domański 2011]. Marketing terytorialny stanowi również przedmiot spotkań naukowców, którzy docenili rolę tej koncepcji w rozwoju miasta i regionu [Koszałka 2010; Szulce, Florek $2005]^{3}$. Zaobserwować można coraz większe zainteresowanie autorów tą problematyką. Niemal na wszystkich zjazdach środowiska marketingowego $^{4}$, które odbywają się co dwa lata, marketing terytorialny stanowi temat przewodni sesji merytorycznej. Świadczyć to może o dynamicznym rozwoju tej koncepcji, ale także o poszukiwaniu nowych obszarów wykorzystania myśli marketingowej. Polscy autorzy zaczynają wpisywać

2 W ostatnich latach ukazały się podręczniki z zakresu marketingu terytorialnego takich autorów, jak: Florek [2006, 2013]; Łazarko, Niedzielska [2011]; Florek, Augustyn [2011]; Duczkowska-Piasecka [2013].

3 Cykliczne konferencje na ten temat odbywają się w Szczecinie oraz Białej Podlaskiej. Ich pokłosiem są interesujące wydawnictwa pokonferencyjne.

4 Są to zjazdy Katedr Marketingu, Handlu i Konsumpcji. W roku 2014 odbył się już dwudziesty piąty taki zjazd. 
się w światowe nurty badań, które jak już wspominaliśmy, mocno podkreślają znaczenie marki terytorialnej. Publikacje rodzimych autorów [Florek 2014; Glińska 2016; Hereźniak 2011; Raszkowski 2014], podejmujące problematykę marki terytorialnej, świadczą o tym, że ten nurt jest obiecujący również w Polsce.

Bliższa analiza podejmowanych w Polsce problemów badawczych czy wykorzystywanych w badaniach teorii, a także metod badawczych prowadzi do wniosku, że problemy marketingu terytorialnego w ujęciu budowania relacji $z$ interesariuszami instytucjonalnymi nie doczekały się wyczerpującej, naukowej prezentacji. Większość tekstów polskich autorów nawiązuje do przypadków działań praktycznych, z których gros to przypadki pozytywne. Inni wątek współdziałania $\mathrm{z}$ interesariuszami instytucjonalnymi poruszają tylko w kontekście budowania marki terytorialnej. Część badaczy cytuje ograniczoną grupę autorów zagranicznych (Meffert, Girard, Gold, Ward) i stara się wyciągać własne wnioski na podstawie analogii i zdroworozsądkowej racjonalności. Brakuje studiów bazujących na podejściu interpretatywnym, mocno opartym na badaniach jakościowych, uwzględniających społeczny kontekst analizowanych zjawisk.

Warto podkreślić, że część publikacji na ten temat to prace powstające $\mathrm{w}$ procesie nadawania stopni naukowych, a więc doktorskie i habilitacyjne. $Z$ natury rzeczy zawierają one rozważania o charakterze teoretycznym, co przyczynia się do rozwoju badanej problematyki [Czornik 2005; Kauf 2009; Kowalik 2011; Florek 2014]. Szansy na rozwój marketingu terytorialnego należy upatrywać również w rosnącej liczbie składanych na ten temat wniosków badawczych do Naukowego Centrum Nauki, chociaż nie przełożyło się to na wyraźne zwiększenie liczby takich projektów zakwalifikowanych do finansowania ze środków publicznych. Warto się jednocześnie zastanowić, czy relatywnie duży odsetek projektów nieuzyskujących finansowania może świadczyć o trudnościach metodologicznych, na jakie napotykają autorzy przy przygotowywaniu wniosków.

Podsumowując powyższe rozważania, należy podkreślić, że dotychczasowy rozwój marketingu terytorialnego opiera się na wymianie rynkowej, która w sektorze publicznym stała się faktem dzięki wprowadzaniu modelu nowego zarządzania publicznego. Nie rozwinięto jak dotychczas problematyki marketingu terytorialnego w ujęciu relacyjnym, czyli takim, które wykorzystuje potencjał partnerów instytucjonalnych organizacji terytorialnej do zaspakajania potrzeb docelowych grup użytkowników terytorium. Identyfikując takie pole badawcze, zasadne jest przyjrzenie się, jak koncepcja marketingowa odnalazła się w kontekście relacyjnym w sektorze przedsiębiorstw, co może stanowić inspirację do dalszych rozważań. 


\subsection{Marketing relacji w sektorze przedsiębiorstw}

Dynamiczne zmiany w otoczeniu organizacji publicznej i rozwój koncepcji marketingu w sektorze przedsiębiorstw skłaniają do refleksji, jak optymalizować procesy marketingowe w sektorze publicznym, wykorzystując podejście relacyjne rozwijane w sektorze prywatnym. W tym celu zdecydowano się poświęcić kolejną część rozdziału na zaprezentowanie współczesnych przemian myśli marketingowej, zwłaszcza koncepcji marketingu relacji, która zdaniem autora koresponduje z obecnymi wyzwaniami sektora publicznego. Natomiast prezentowana w dalszej części rozdziału koncepcja marketingu interesariuszy, wypływająca z koncepcji marketingu relacji, jest dowodem na to, że w sektorze prywatnym odchodzi się od traktowania potrzeb klienta jako jedynego celu funkcjonowania przedsiębiorstwa na rzecz działań uwzględniających oczekiwania także innych interesariuszy.

\subsubsection{Rozwój marketingu relacji w sektorze przedsiębiorstw}

We współczesnym marketingu powszechnie podzielana jest opinia, że prawdziwym celem organizacji komercyjnej jest kształtowanie i utrzymywanie wzajemnie korzystnych relacji organizacji z wybranymi grupami klientów. Równie powszechnie akceptowane jest stwierdzenie, że dobra relacja oznacza przepływ wartości w obie strony, a więc klient otrzymuje wymierną wartość z pozostawania w relacji, zaś organizacja realizuje wartość w formie zwiększonej zyskowności.

Już w latach 80. XX w. Levitt [1983, s. 87-93] zwrócił uwagę, że prawdziwa wartość relacji pomiędzy klientem a oferentem ma miejsce dopiero po dokonaniu transakcji. Wykazywał on, że oferent nie powinien kłaść już nacisku na sam moment dokonywania transakcji, ale powinien skoncentrować się na dostarczaniu możliwie wysokiej wartości (oferty) klientowi w ciągu trwania całej relacji. Wątek długookresowości w sposób kompleksowy opisał L. Berry [1983], który rozwinął marketing relacji jako koncepcję zarządzania firmą usługową. Wyróżnił on pięć strategicznych elementów, które do dziś stanowią teoretyczną bazę marketingu relacji w sektorze usług: (1) rozwijanie rdzenia usługi, (2) dostosowanie usługi do oczekiwań klienta indywidualnego, (3) wzbogacanie rdzenia usługi o specjalne korzyści (wartość dodana), (4) cenowe stymulowanie lojalności konsumentów oraz (5) podejmowanie intensywnych działań marketingowych wobec własnych pracowników [Berry 1995, s. 236]. 
Jednym z pierwszych autorów, którzy wskazywali na różnice pomiędzy marketingiem transakcyjnym a marketingiem relacji, była B. Jackson [1985]. Zaakcentowała ona wpływ specyfiki rynku przemysłowego na możliwe relacje z klientami instytucjonalnymi. Jej zdaniem tworzenie i wzmacnianie długookresowych relacji wymaga koncentracji na szeregu działań, które muszą być realizowane w długim okresie w określony sposób. Prowadziła badania w takich branżach, jak: usługi transportowe, usługi telekomunikacyjne oraz usługi informatyczne. Badania na temat marketingu relacji prowadzone były również w Europie. Na uwagę zasługuje tu dorobek autorów szwedzkich i fińskich, których analizy prowadzone na ten temat w latach 80 . i 90. XX w. wzbudziły spore zainteresowanie. Przedmiotem tych badań było wykorzystanie marketingu w sektorze usług i jego wpływ na podnoszenie jakości tych usług. Inni autorzy [Axelsson, Easton 1992; Hakansson 1982; Ford 1990] koncentrowali się w swoich wczesnych pracach na interakcjach pomiędzy sieciami na rynkach przemysłowych.

Powyższe wczesne prace dotyczące marketingu relacji w sektorze usług i sektorze przemysłowym dały początek wielu innym, które od lat 90. XX w. zaczęły masowo opisywać fenomen marketingu relacji. Publikacje z tego zakresu uwzględniały uwarunkowania, w których się on rozwijał, stąd L. Coote [1994] zaproponował następujące jego szkoły:

- brytyjsko-australijską (anglo-australian approach)

- skandynawską (nordic approach)

- północnoamerykańską (north-american approach).

Pierwsza $\mathrm{z}$ wymienionych szkół podkreśla integrację zarządzania jakością, marketingu usług oraz ekonomii relacji z klientem [Christopher et al. 1991]. Druga wyrasta $\mathrm{z}$ dorobku takich autorów skandynawskich, jak Grönroos [1990, s. 5-9]. Powstała na bazie sieciowych teorii interakcji marketingu przemysłowego, marketingu usług i marketingu rozumianego tu jako ekonomia budowania relacji z klientem. Trzecia szkoła podkreśla relacje pomiędzy kupującym i oferentem w ramach organizacji. Podstawą tego podejścia są prace autorów amerykańskich [Berry 1995; Levitt 1983].

Szkoła północnoamerykańska wydaje się szczególnie ważna dla rozwoju marketingu terytorialnego w wymiarze relacyjnym, zwłaszcza tam, gdzie organizacje terytorialne są odpowiednio duże, a ich kierownictwo (marszałek, prezydent) nie jest w stanie zarządzać wszystkimi relacjami zewnętrznymi samodzielnie. W takich warunkach to menedżerowie publiczni, stojący na czele jednostek organizacyjnych, nabierają znaczenia w zakresie budowania relacji zewnętrznych organizacji.

Kolejne szkoły marketingu relacji zilustrowano na rys. 2.5. 
szkoła brytyjsko-australijska marketingu relacji

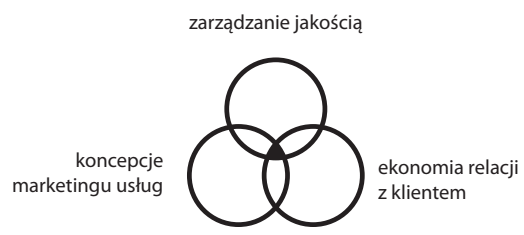

szkoła skandynawska marketingu relacji

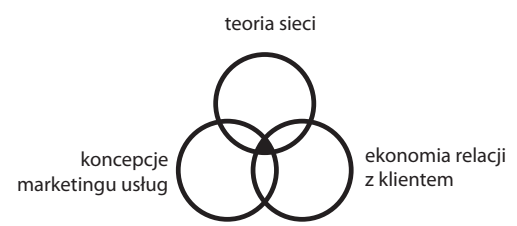

szkoła północnoamerykańska marketingu relacji

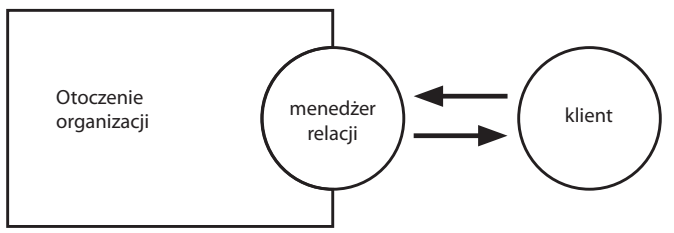

Rys. 2.5. Wczesne szkoły badań nad marketingiem relacji Źródło: [Christopher et al. 2008, s. 6-9].

W Europie kolebką marketingu relacji była Wielka Brytania. Ukazywało się tam wiele publikacji na ten temat, a także szeroko wykorzystywano tę koncepcję w sektorze przedsiębiorstw. Na podstawie prowadzonych badań A. Payne [1995] zidentyfikował najważniejsze zmiany w marketingu, specyficzne dla podejścia relacyjnego:

- zmianę orientacji działań marketingowych z ukierunkowania na transakcję na zorientowanie na utrzymanie klienta,

- maksymalizowanie długookresowej wartości dla klienta,

- przejście od marketingu w ujęciu funkcjonalnym (functional marketing) do marketingu w ujęciu zintegrowanym (cross-functionally based marketing),

- traktowanie marketingu jako filozofii całego biznesu, a nie ograniczanie go do działu marketingu. Podejście takie wymaga zmian organizacyjnych, zrozumienia, że każdy w organizacji współtworzy ofertę dla klienta.

Autor ten podkreśla konieczność koncentrowania wysiłków marketingowych na różnych rynkach, w tym: wewnętrznym, dostawców, pośredników, potencjalnych pracowników, wpływowych instytucji, a nie tylko na rynku klientów. Aby skutecznie konkurować o klienta, który przynosi organizacji zysk, należy zidentyfikować rynki innych interesariuszy przedsiębiorstwa, wobec których warto podjąć działania. Wymienione 
rynki mogą bezpośrednio lub pośrednio wpływać na powodzenie organizacji [Christopher, Payne, Ballantyne 1991].

Nie ulega wątpliwości, że współcześnie marketing relacji jest koncepcją wyraźnie odbiegającą od klasycznego marketingu transakcyjnego. W sektorze przedsiębiorstw przewaga konkurencyjna w coraz większym stopniu zależy bowiem od współdziałania, w opozycji do aktywnej rywalizacji. Rośnie tym samym rola relacji traktowanych jako zasób organizacji. E. Gummesson [2002, s. 27-29] przyznaje, że marketing relacji wnosi szereg fundamentalnych wartości, co sprawia, że dalszy rozwój tej koncepcji ma stabilne podstawy. Wymienia on takie specyficzne jego cechy, jak: długookresowa współpraca i wzajemne kreowanie wartości u wszystkich partnerów, wkład wszystkich zaangażowanych stron w wytwarzanie wartości czy brak możliwości wpisywania relacji w biurokratyczno-prawny system wartości [Rogoziński 2000, s. 30].

Problematyka kształtowania szeroko pojętych relacji przedsiębiorstwa była podejmowana przez wielu uznanych autorów w dziedzinie marketingu w latach 90. XX w. ${ }^{5}$ Ich udziałem stały się nowe koncepcje marketingu z uwzględnieniem całego otoczenia sieciowych powiązań przedsiębiorstwa. Autorzy zaczęli dostrzegać korzystny wpływ relacji z interesariuszami na podnoszenie konkurencyjności przedsiębiorstwa [Hunt 1997; Reichheld 1996].

Interesujące podejście do marketingu relacji prezentują K. Möller i A. Halinen (rys. 2.6). Odnosi się ono do teoretycznych podstaw obu jego wymiarów: rynkowego/konkurencyjnego i sieciowego.

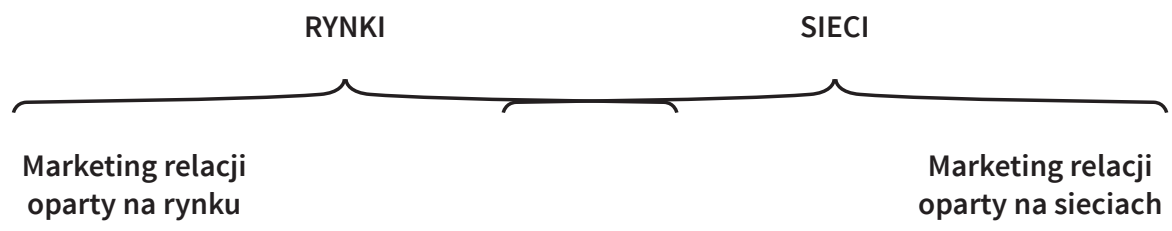

Niska złożoność relacji

Wysoka złożoność relacji

Rys. 2.6. Dwoistość marketingu relacji

Źródto: [Möller, Halinen 2000, s. 43].

5 Wśród autorów podejmujących tę problematykę byli m.in.: Christopher, Payne, Ballantyne [1994], Kotler [1992], Hunt, Morgan [1994, s. 18-28], Doyle [1995, s. 2341], Gummesson [2002]. 
Na rys. 2.6 pokazano, że opieranie marketingu relacji na sieciach stanowi wyzwanie, ponieważ wymaga uwzględnienia większej liczby bardziej złożonych relacji, w których uczestniczą organizacje. Wydaje się jednak, że właśnie świadome zarządzanie sieciami będzie decydować o przewadze relacyjnej organizacji.

W tym samym okresie powstało szereg modeli relacji będących bazą dla działań marketingowych. Interesujące zestawienie można odnaleźć w opracowaniu J. Egana [2008, s. 146-147]. Zaproponowany przez niego model relacji przedsiębiorstwa obejmuje: relacje z klientami, relacje wewnętrzne, relacje $\mathrm{z}$ dostawcami oraz relacje $\mathrm{z}$ interesariuszami (rys. 2.7). Model ten, jak twierdzi sam badacz, jest pewnym kompromisem w odniesieniu do czterech innych, w których dostrzegł wspólne cechy. Ich autorami są: P. Doyle [1995], S. D. Hunt i R. M. Morgan [1994], M. Christopher, A. Payne i D. Ballantyne [1994] oraz E. Gummesson [2002]. Model ten zdaje się porządkować coraz bardziej złożone relacje przedsiębiorstwa.

Poniżej dokonamy krótkiej charakterystyki poszczególnych rodzajów relacji prezentowanych na rys. 2.7, aby następnie zastanowić się nad możliwością ich adaptacji do organizacji publicznych, zwłaszcza organizacji terytorialnych.

Relacje $\mathbf{z}$ klientami. To niewątpliwie najważniejszy element modelu. Mimo rosnącego znaczenia innych związków przedsiębiorstwa, te $\mathrm{z}$ klientami pozostają $\mathrm{w}$ centrum uwagi omawianej koncepcji marketingu przedsiębiorstw. Marketing relacji zdaje się tu odpowiadać na pytanie: co przedsiębiorstwo może zrobić dla klienta lub z klientem, a nie tylko - jak to było wcześniej - klientowi. Klientów można ogólnie podzielić na pośrednich oraz ostatecznych czy docelowych. Dla każdej z tych grup należy stosować odmienne podejście relacyjne.

Relacje wewnętrzne. Kształtowanie właściwych relacji przedsiębiorstwa ze swoimi pracownikami staje się istotnym obszarem marketingu relacji. Wynika to z faktu, że relacje przedsiębiorstwo-klienci kształtowane są często bezpośrednio przez pracowników przedsiębiorstwa, stąd ogromna rola jakości tych relacji dla konkurencyjności firmy. Relacje wewnętrzne nie powinny się ograniczać do pracowników przedsiębiorstwa, ale powinny uwzględniać również relacje istniejące w jego jednostkach organizacyjnych, działach funkcjonalnych itp. Wewnętrzny klimat w firmie ma zasadniczy wpływ na satysfakcję pracowników oraz na lojalność klientów. W przedsiębiorstwach usługowych za kontakty z klientami odpowiedzialny jest personel, natomiast w przedsiębiorstwach produkcyjnych niekiedy funkcje te pełnią pośrednicy. Mogą tu być również stosowane różne rozwiązania $\mathrm{z}$ wykorzystaniem nowoczesnych technologii (ICT). 


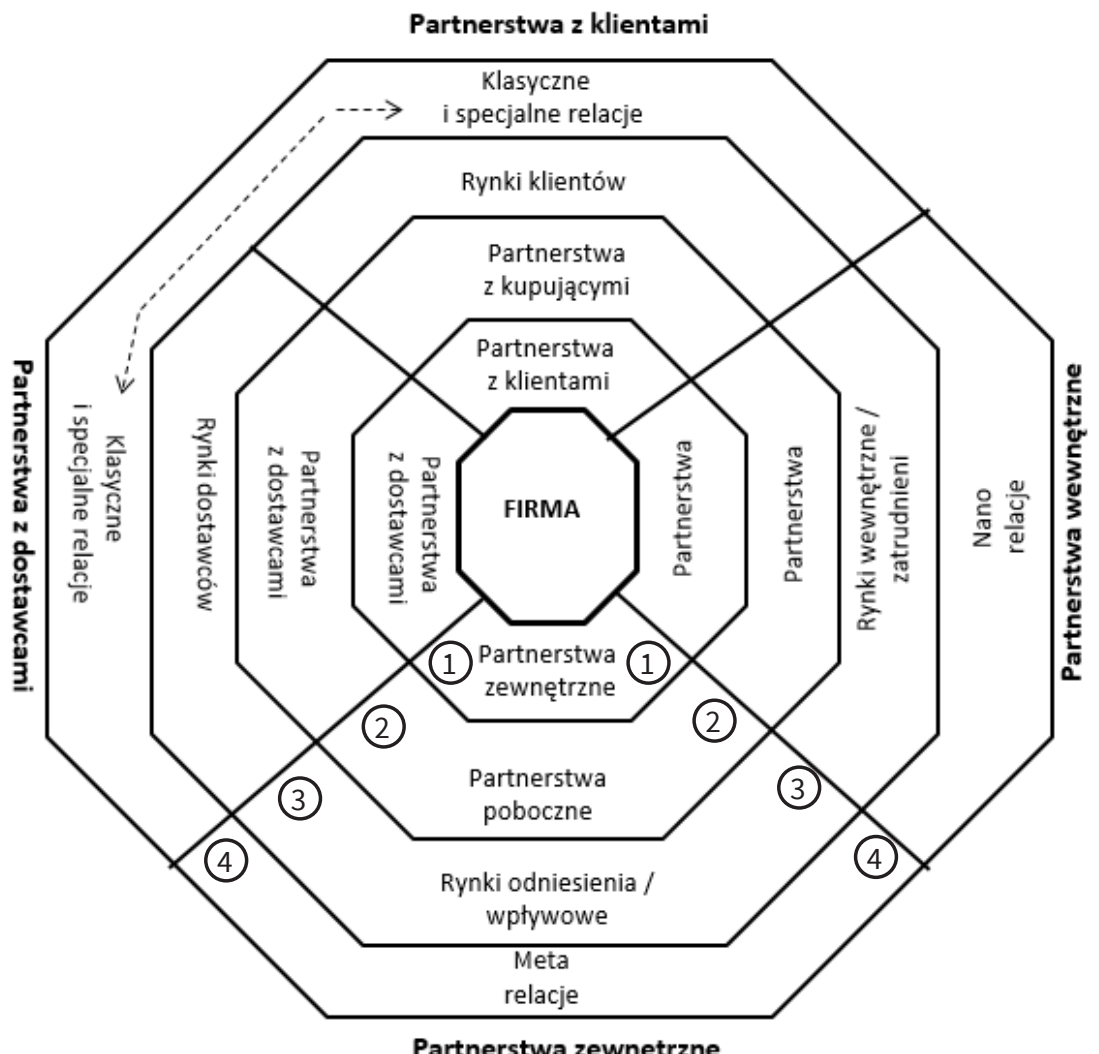

Partnerstwa zewnętrzne

(1) Firma i jej relacje

(2) Cztery partnerstwa i dziesięć relacji

(3) Sześć rynków

(4) 30 relacji
[Doyle 1995]

[Hunt, Morgan 1994]

[Christopher et al. 1991]

[Gummenson 1996, 1999]

Rys. 2.7. Organizacja (firma) i jej relacje partnerskie Źródło: [Egan 2008, s. 147].

Relacje $\mathrm{z}$ dostawcami. W ramach relacji $\mathrm{z}$ dostawcami odnajdujemy dwie kategorie. Relacje z dostawcami półproduktów, producentami, pośrednikami oraz relacje $z$ dostawcami usług. Szczególnie istotna jest pierwsza $z$ wymienionych relacji, ze względu na jej rosnący w ostatnich latach zakres. Dzieje się tak za sprawą outsoursingu, który polega najogólniej na odchudzaniu przedsiębiorstwa, czyli przekazywaniu podmiotom zewnętrznym wykonywania podzespołów do dalszej produkcji lub 
przekazywanie usług na rzecz innych firm. W niektórych branżach, np. motoryzacyjnej, skala tego rodzaju relacji z dostawcami jest olbrzymia.

Relacje $\mathrm{z}$ pozostałymi interesariuszami. Są to po pierwsze relacje poziome $\mathrm{z}$ innymi przedsiębiorstwami. Tworzone $\mathrm{w}$ ten sposób sieci powiązań mogą rywalizować $\mathrm{z}$ innymi sieciami w tym samym bądź innym sektorze. Drugim wymiarem relacji zewnętrznych są relacje z podmiotami z innych sektorów. Utrzymywanie takich relacji może mieć wpływ na funkcjonowanie przedsiębiorstwa w długim okresie. Wymienić tu można przykładowo takich potencjalnych partnerów, jak władze lokalne czy regionalne, organizacje społeczne itp. Niewątpliwie rozmiary przedsiębiorstwa będą determinowały rolę tych relacji oraz sam fakt ich nawiązywania i utrzymywania.

Spośród wymienionych kategorii relacji warto zwrócić uwagę na tę ostatnią (relacje z interesariuszami instytucjonalnymi), bo to przejaw relacji międzyorganizacyjnych organizacji publicznych. Będziemy je analizować w kolejnych częściach monografii.

Inny podział relacji zaproponowali K. Möller i A. Halinen [2000, s. 40]. Zawęzili oni relacje do dwóch rodzajów (tab. 2.2). Pierwszy to relacje przedsiębiorstwa z klientem. Do ich badania mogą być wykorzystywane tradycyjne, ilościowe metody analizy. Są stosunkowo proste, ale niezbyt trwałe, łatwo podlegają zmianom. Sprowadzają się głównie do pojedynczych transakcji i stosunkowo rzadko mają charakter długookresowy. Stroną znacznie bardziej aktywną jest sprzedający. Musi on ciągle zabiegać o klientów, o jak największą ich liczbę, stosując różne techniki ich pozyskiwania, także te z zakresu psychologii.

Natomiast relacje międzyorganizacyjne w mniejszym stopniu poddają się ilościowym metodom analizy. Dzieje się tak ze względu na relatywną rzadkość takich transakcji. Ich partnerzy są bardziej od siebie współzależni i ma to związek $\mathrm{z}$ ich powiązaniem $\mathrm{z}$ zasobami. W odróżnieniu od relacji z klientami relacje międzyorganizacyjne są co prawda rzadsze, ale mają charakter długookresowy. W rezultacie można je analizować przy pomocy metod jakościowych.

W wydanej ostatnio książce Kotlera i Kellera odnajdujemy kolejną koncepcję marketingu nazywanego tam marketingiem holistycznym. Marketing relacji jest tam jednym $\mathrm{z}$ czterech filarów tej koncepcji, obok marketingu zintegrowanego, marketingu dokonań i marketingu wewnętrznego [Kotler, Keller 2012, s. 21]. W publikacji tej znacznie poszerzona została podmiotowa kategoria klienta, będącego do niedawna kluczowym (jedynym) partnerem firmy. Według nowego podejścia czterema głównymi partnerami w marketingu relacji są: klienci, pracownicy, partnerzy marketingowi (kanały, dostawcy, dystrybutorzy, dilerzy, agencje) oraz partnerzy z branży finansowej (akcjonariusze, 
inwestorzy, analitycy). Zgodnie z tą koncepcją marketingowcy muszą kreować wartość dla wszystkich tych partnerów i równoważyć poziom zysków dla poszczególnych podmiotów związanych z firmą. Budowa z nimi silnych relacji wymaga znajomości ich możliwości i zasobów, a także potrzeb oraz celów.

Tabela 2.2. Rodzaje relacji marketingowych i ich charakterystyka

\begin{tabular}{|l|l|l|}
\hline \multicolumn{1}{|c|}{ Cechy relacji } & \multicolumn{1}{|c|}{$\begin{array}{c}\text { Relacje z klientem } \\
\text { (mała złożoność relacji) }\end{array}$} & \multicolumn{1}{|c|}{$\begin{array}{c}\text { Relacje międzyorganizacyjne } \\
\text { (duża złożoność relacji) }\end{array}$} \\
\hline Kluczowa relacja & $\begin{array}{l}\text { Nacisk kładziony jest na relację } \\
\text { oferent-indywidualny klient }\end{array}$ & $\begin{array}{l}\text { Nacisk kładziony jest na relację } \\
\text { dostawca-odbiorca oraz } \\
\text { wymianę w ramach sieci }\end{array}$ \\
\hline $\begin{array}{l}\text { Liczba podmiotów } \\
\text { relacji }\end{array}$ & Duża liczba klientów & $\begin{array}{l}\text { Niewielka liczba aktorów } \\
\text { różnych obszarów } \\
\text { (przedsiębiorstwa, NGO-y, } \\
\text { organizacje publiczne oraz } \\
\text { indywidualni uczestnicy relacji) }\end{array}$ \\
\hline Stopień zależności & $\begin{array}{l}\text { Niewielka współzależność, } \\
\text { bowiem zasoby (relacje, } \\
\text { produkty, informacje itp.) mają } \\
\text { charakter substytucyjny }\end{array}$ & $\begin{array}{l}\text { Wzajemna współzależność } \\
\text { wynikająca z posiadanych } \\
\text { zasobów }\end{array}$ \\
\hline $\begin{array}{l}\text { tatwość zmiany } \\
\text { partnera relacji }\end{array}$ & $\begin{array}{l}\text { Stosunkowo łatwa zmiana } \\
\text { partnera relacji }\end{array}$ & $\begin{array}{l}\text { Aktorzy dysponują różnymi } \\
\text { zasobami, co ogranicza } \\
\text { możliwość zmiany partnera przy } \\
\text { istniejących relacjach }\end{array}$ \\
\hline $\begin{array}{l}\text { Aktywność aktorów } \\
\text { relacji }\end{array}$ & $\begin{array}{l}\text { Sprzedający jest stroną } \\
\text { aktywniejszą }\end{array}$ & $\begin{array}{l}\text { Każdy aktor ma możliwość bycia } \\
\text { aktywnym }\end{array}$ \\
\hline $\begin{array}{l}\text { Częstotliwość } \\
\text { transakcji/relacji }\end{array}$ & $\begin{array}{l}\text { Przywiązuje się wagę do } \\
\text { pojedynczych transakcji. } \\
\text { Rzadziej priorytetem są relacje } \\
\text { długookresowe }\end{array}$ & $\begin{array}{l}\text { Transakcje są relatywnie } \\
\text { rzadsze, ale relacje } \\
\text { długookresowe }\end{array}$ \\
\hline $\begin{array}{l}\text { Nacisk kładziony jest na } \\
\text { następujące aspekty wymiany: } \\
\text { zarządczy, ekonomiczny, } \\
\text { psychologiczny }\end{array}$ & $\begin{array}{l}\text { Nacisk kładziony jest na } \\
\text { zasoby oraz na spoteczne } \\
\text { i wewnątrzfunkcjonalne relacje } \\
\text { wymienne }\end{array}$ \\
\hline
\end{tabular}

Źródło: opracowanie własne na podstawie [Möller, Halinen 2000, s. 40].

Kotler i Keller odnoszą się również do problematyki sieci, która $\mathrm{w}$ ostatnich latach dynamicznie się rozwija i znalazła należne miejsce $\mathrm{w}$ teorii zarządzania. Ich zdaniem ostatecznym rezultatem marketingu relacji jest unikatowe bogactwo danej firmy w postaci sieci marketin- 
gowej. Tworzy ją firma oraz sieć wspierających ją partnerów - klientów, pracowników, pośredników, detalistów, dostawców i innych, z którymi wypracowała trwałe, wzajemnie korzystne relacje [Kotler, Keller 2012, s. 22]. Anderson, Hakansson i Johanson formułują w tym kontekście następującą rekomendację dla przedsiębiorców: „buduj efektywne sieci relacji z kluczowymi partnerami, a zyski pojawią się same" [Anderson, Hakansson, Johanson 1994, s. 1-15].

Należy zwrócić uwagę, że tradycyjna struktura instrumentów marketingowych też ulega zmianie. Dotychczasowa formuła $4 \mathrm{P}$ występuje obecnie w zupełnie innej konfiguracji: ludzie (people), procesy (processes), programy (programs), dokonania (performance) [Kotler, Keller 2012, s. 27]. Zarysowane wyżej nurty znajdują odzwierciedlenie w najnowszej literaturze marketingowej, kierowanej zarówno do praktyków gospodarczych, jak i naukowców oraz studentów. W literaturze tej orientację na klienta zastępuje się zupełnie nową, szerszą formułą [Kotler, Kartajaya, Setiawan 2010].

Dyskusję nad zmieniającą się rolą marketingu trafnie podsumowuje F. E. Webster, którego zdaniem

formułowany jest obecnie całkowicie nowy paradygmat zarządzania marketingowego, polegający na przewartościowaniu jego istoty od firm do klientów, od produktów do usług i korzyści, od transakcji do relacji, od produkcji do wspólnego kreowania wartości z partnerami biznesowymi i klientami oraz od fizycznych zasobów i pracy do zasobów wiedzy i pozycji firmy w łańcuchu wartości [Webster 2005, s. 125].

Tak rozumiany marketing jest w pełni zgodny z uwarunkowaniami, jakie występują aktualnie na rynku. Przedsiębiorstwo, które chce osiągnąć sukces, musi dokonać przewartościowania swoich celów i sposobów ich realizacji. Musi realizować wspólne cele z partnerami biznesowymi oraz klientami i koncentrować się na zasobach wiedzy, a także swojej wysokiej pozycji w łańcuchu wartości.

Podobny kierunek zmian co do roli marketingu w przyszłości dostrzegają Kotler i Keller. Ich zdaniem:

marketing musi być bardziej holistyczny i mniej sektorowy [...], w nadchodzących latach będziemy świadkami: upadku działów marketingu, upadku rozrzutnego marketingu i rozwoju marketingu opartego na zwrocie z inwestycji, upadku intuicji marketingowej i rozwoju nauki marketingowej, upadku marketingu manualnego i rozwoju marketingu zarazem zautomatyzowanego i kreatywnego, upadku marketingu masowego i rozwoju marketingu precyzyjnie adresowanego [Kotler, Keller 2012, s. 696]. 
Marketing holistyczny to zatem: integrowanie rozpoznawania wartości i dostarczania wartości w celu budowania długofalowej, wzajemnie satysfakcjonującej relacji oraz wspólnego powodzenia kluczowych interesariuszy [Kotler, Keller 2012, s. 40].

Analiza zachodzących zmian w marketingu przedsiębiorstw może stanowić inspirację dla osób poszukujących możliwości wykorzystania tej koncepcji w sektorze publicznym, który dla zwiększenia swojej efektywności musi się bardziej otworzyć na relacje zewnętrzne i potrafić nimi zarządzać.

\subsubsection{Marketing interesariuszy jako nowy wymiar marketingu relacji}

W ostatnich latach w nurcie marketingu relacji wyodrębniany jest tzw. marketing interesariuszy (stakeholder marketing). Duży wpływ na jego powstanie miała teoria interesariuszy (stakeholder theory), której popularność nadal rośnie. Zakłada ona, że celem organizacji jest osiągnięcie równowagi pomiędzy sprzecznymi, konfliktowymi celami, do jakich dążą grupy interesów związane $\mathrm{z}$ działalnością organizacji [Urbanek 2005, s. 44]. Zgodnie z tą teorią menedżerowie, podejmując kluczowe dla organizacji decyzje, powinni brać pod uwagę nie tylko cele swojej organizacji, lecz także cele otaczających ją interesariuszy. Interesariusz rozumiany jest tu jako „każda grupa lub jednostka, która może wpływać na organizację, lub podlega wpływowi organizacji w procesie realizacji jej celów" [Freeman 1984, s. 46]. Interesariusze definiowani są więc bardzo szeroko, zaś ich zakres wykracza poza środowisko organizacji. W sposób ogólny główne grupy interesariuszy przedsiębiorstwa przedstawiono na rys. 2.8 i należą do nich: udziałowcy (inwestorzy), dostawcy, konsumenci, pracownicy, ale także władza publiczna, grupy polityczne, organizacje samorządu gospodarczego oraz społeczność lokalna.

W teorii tej pojawia się konflikt interesów, ograniczona racjonalność i nastawienie jednostek na realizację własnych interesów (oportunizm).

Zwiększona wrażliwość konsumentów na kwestie będące w istocie elementami otoczenia przedsiębiorstwa, np. na: ochronę środowiska naturalnego, problemy społeczne, łamanie praw człowieka czy presję ze strony różnych grup interesariuszy firmy, takich jak: pracownicy, udziałowcy, władza publiczna lub działacze społeczni, skłaniają do odchodzenia od modelu biznesu, w którym klient jest jedynym celem aktywności marketingowej, a firma głównym czy jedynym beneficjentem [Bhattacharya 2010, s. 1-3]. Można zaryzykować stwierdzenie, że marketing interesariuszy jest nowym wymiarem marketingu relacji. Proces ewolucji koncepcji marketingowych wpisujących się w nurt marketingu relacji zaprezentowano na rys. 2.9. 


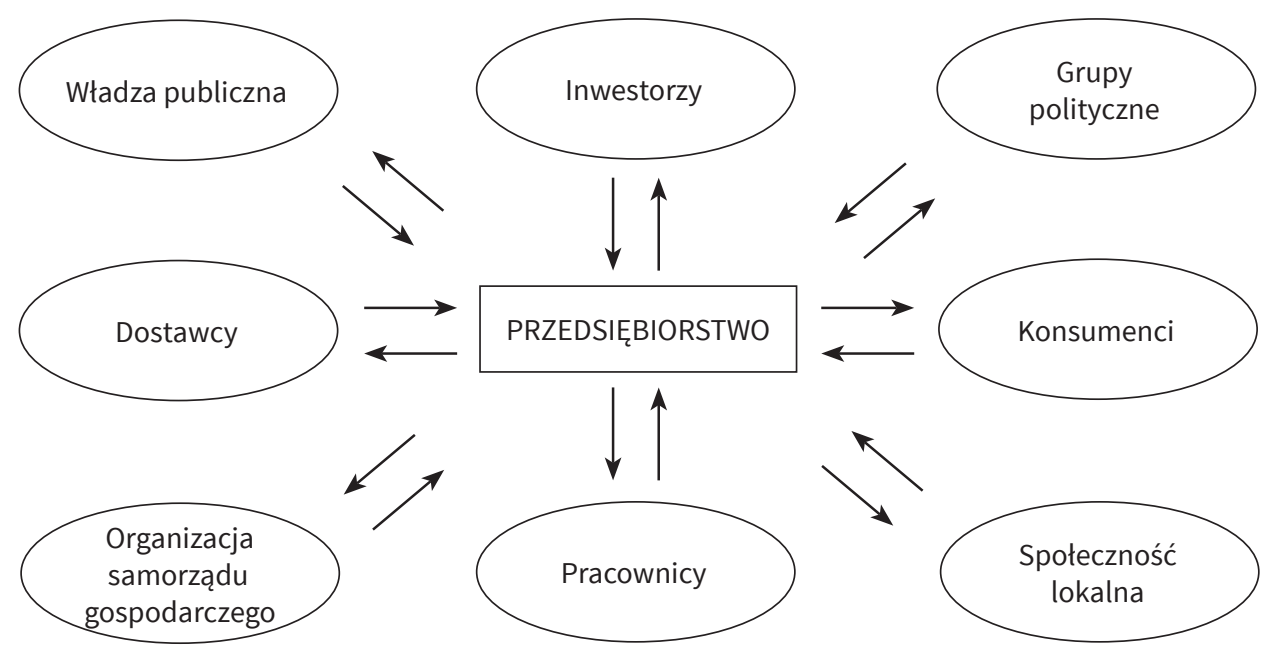

Rys. 2.8. Model interesariuszy przedsiębiorstwa Źródto: [Donaldson, Preston 1995, s. 68].

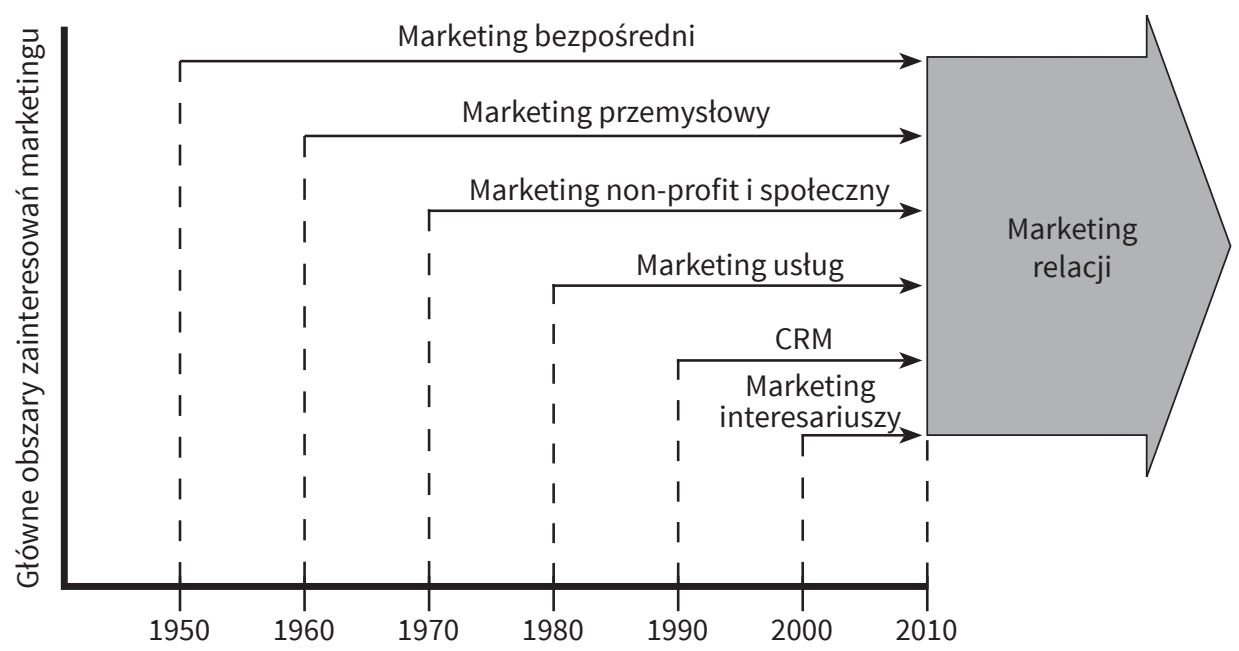

Rys. 2.9. Marketing interesariuszy jako nowy wymiar marketingu relacji Źródło: opracowanie własne z wykorzystaniem [Christopher, Payne, Ballantyne 2008, s. XIV]. 
Zaznaczony na rys. 2.9 marketing interesariuszy wiąże planowanie, wdrażanie i ocenę inicjatyw marketingowych w taki sposób, aby przyniosły korzyści wszystkim jej interesariuszom. Można ich ogólnie podzielić na dwie grupy, a więc na tych bezpośrednio zaangażowanych $\mathrm{w}$ dane przedsięwzięcie, np. biznesowe (klienci, pośrednicy, dostawcy, ale również pracownicy czy akcjonariusze), oraz na tych, którzy w sposób pośredni mogą osiągać korzyści z działalności organizacji (władza publiczna, organizacje non-profit, społeczeństwo). Chociaż teoria interesariuszy istnieje już od przeszło trzech dekad i stanowi bardzo użyteczny punkt wyjścia do wielu podejść analitycznych i badawczych [Freeman 1984], to marketing w bardzo niewielkim stopniu wykorzystał jej możliwości, w przeciwieństwie do szerszej dyscypliny - zarządzania, zwłaszcza zarządzania strategicznego [Svendsen 1998; Post, Preston, Sachs 2002; Philips 2003].

W przeszłości zdarzały się co prawda próby nawiązywania do teorii interesariuszy przez autorów z obszaru marketingu [Polonsky 1995, s. 2946], ale punktem przełomowym była dopiero seria międzynarodowych spotkań naukowych organizowanych w latach 2007-2009 wspólnie przez trzy podmioty: Aspen Institute's Business and Society Program, Boston University oraz Marketing Science Institute [Bhattacharya 2010, s. 1-3]. Spotkania te służyły pogłębionej dyskusji nad marketingiem interesariuszy jako koncepcją wpisującą się w społeczną orientację przedsiębiorstwa. Rezultatem tych spotkań była inspirująca publikacja na temat marketingu interesariuszy. Ukazała się ona w 2010 r. jako specjalny numer wydawanego przez American Marketing Association czasopisma naukowego: "Journal of Public Policy \& Marketing" [2010]. Jej zawartość może stanowić ważny sygnał dla badaczy problemów marketingu, zwracający uwagę na potrzebę akcentowania społecznego wymiaru marketingu.

W sposób uporządkowany najważniejsze cechy koncepcji marketingu interesariuszy przedstawili N. C. Smith, G. Palazzo i C. B. Bhattacharya [2010, s. 627-628]. Ich zdaniem marketing ten:

- bierze pod uwagę interesy szeroko pojętych interesariuszy w planowaniu, wdrażaniu i ocenie strategii marketingowej;

- jest świadomy wpływu decyzji marketingowych na interesariuszy, związanych zarówno z produkcją, jak i dystrybucją, a także na społeczeństwo i otoczenie organizacji;

- bada związki istniejące między interesariuszami;

- stara się zrozumieć jak marketingowcy radzą sobie ze wspólnymi interesami i konfliktami w relacjach z interesariuszami;

- nie powinien być sprzeczny z interesami akcjonariuszy.

W świecie zorientowanym na interesariuszy formułowanie strategii marketingowej rozpoczynać się powinno od wszechstronnej oceny ich potrzeb - zarówno funkcjonalnych, jak i psychospołecznych. Zrozumienie 
tych potrzeb umożliwia organizacji stworzenie szeregu czynników produkcji wypracowanych wspólnie z interesariuszami. Podejście to sprawia, że interesariusze wspólnie tworzą wartość z firmą i dla firmy. Jako przykład można podać inicjatywy zmierzające do odpowiedniego przetwarzania odpadów czy ich pozbywania się, co pomaga firmie i jej klientom wspólnie tworzyć wartość dla środowiska naturalnego. Uczestnictwo w procesie wspólnego tworzenia pozwala interesariuszom (np. dostawcom, odbiorcom, pracownikom) budować silniejsze związki z organizacją, które można wyrazić przy pomocy takich pojęć, jak tożsamość czy zaufanie.

Silne związki oparte na strategiach zorientowanych na interesariuszy stymulują ich zachowania nie tylko na polu biznesu, lecz także w działalności społecznej czy ochronie środowiska [Savitz, Weber 2006]. Korzystne rezultaty $\mathrm{w}$ wymiarze społecznym i środowiskowym nie muszą stanowić ograniczenia w osiąganiu dobrych wyników ekonomicznych. Teza ta jest prawdziwa zwłaszcza w obecnej sytuacji społecznej, w której poparcie dla tego rodzaju marketingu wśród interesariuszy (m.in. klientów) jest coraz większe. Dodajmy, że takie czynniki, jak kultura, koordynacja między działami oraz partnerstwo $z$ organizacjami pozarządowymi wpływają pozytywnie na zdolność organizacji do wdrażania strategii marketingu interesariuszy.

W literaturze wyróżnia się dwie formy praktycznego wykorzystania koncepcji marketingu interesariuszy: miękką (soft) i twardą (hard) [Laczniak, Murphy 2012, s. 284-285]. Dotychczas częściej wykorzystywano jej miękką formę, która posiada charakter instrumentalny i odpowiada zwłaszcza małym firmom. W tym podejściu oczekiwania interesariuszy są negocjowane $\mathrm{z}$ firmą $\mathrm{w}$ sposób indywidualny. Zostają one uwzględnione przez kierownictwo firmy, jeśli mogą jej przynieść zysk w krótkim lub średnim okresie. Należy przy tym pamiętać, że warunkiem przetrwania firmy jest zapewnienie inwestorom zwrotu poniesionych nakładów i zaspokojenie potrzeb klientów. Dodajmy, że zgodnie z tradycyjnym modelem przedsiębiorstwa, wymiar społeczny jego działalności jest sprawą wtórną wobec zysku.

Koncepcja marketingu interesariuszy w tzw. twardej formie, zyskuje obecnie na popularności, co znajduje odzwierciedlenie w literaturze z zakresu zarządzania [Svendsen 1998; Verbeke, Tung 2013, s. 529-543; Bourne 2009]. Ze względu na jej społeczną orientację rozumienie tej koncepcji ulega dość istotnej zmianie. Staje się ona zdecydowanie bardziej normatywna pod względem etycznym, koncentruje się na skali makro i tworzeniu sieci. Interesariusze otrzymują większy wpływ na decyzje, bowiem otwarty z nimi dialog coraz częściej jest wpisany w politykę firmy. Dzięki temu mogą oni współtworzyć wartość dla firmy [Vargo, Lusch 2004, s. 1-17]. Natomiast społeczeństwo, jako jedna z grup interesariu- 
szy, może częściej liczyć na szybką reakcję firm ze względu na coraz częstsze ich poparcie dla społecznej odpowiedzialności biznesu [Elms et al. 2010, s. 401-425].

Jednym $\mathrm{z}$ celów marketingu interesariuszy $\mathrm{w}$ twardej formie jest sprawiedliwe rozłożenie kosztów, tzw. efektów zewnętrznych, pomiędzy całą sieć interesariuszy. Fakt ten powinien być uwzględniany przy budowie strategii firmy, której ważnym elementem powinno być określenie korzyści dla interesariuszy. Wszystko to sprawia, że ponownie należy zrewidować społeczny cel organizacji marketingowych [Svendsen, Laberge 2006]. Potwierdza to D. Mick: „Jeśli marketing ma osiągnąć maksimum swojego potencjału wraz z wypełnianiem swojego społecznego obowiązku, a jednocześnie być bardziej doceniany przez opinię publiczną, celem marketingu musi stać się wspólne dobro" [Mick 2007, s. 291].

G. R. Laczniaki P.E. Murphy [2012, s. 289-290] zwracają jednak uwagę, że w praktyce gospodarczej ta twarda forma koncepcji marketingu interesariuszy może budzić sprzeciw wielu firm, ponieważ nie koncentruje się jedynie na wzroście zysków czy ich maksymalizacji. Taka niechęć jest do pewnego stopnia zrozumiała, bowiem wiele przedsiębiorstw nadal wierzy $\mathrm{w}$ „efektywność rynków” oraz kieruje się w swojej działalności głównie „maksymalizacją własnych korzyści”. Amerykańscy autorzy starają się dowodzić, że społeczne oczekiwania związane $\mathrm{z}$ wynikami działalności gospodarczej wydają się ulegać zmianie. Twierdzą oni, że marketingowcy powitaliby z zadowoleniem zestaw globalnie jednolitych norm etycznych do powszechnego wykorzystywania. Zmniejszałyby one niepewność w zarządzaniu, gdyż wskazywałyby granicę akceptowalnego zachowania firmy w stosunku do wszystkich interesariuszy [Laczniak, Kennedy 2011, s. 12-24].

Pomimo wspomnianego sprzeciwu autorzy ci przewidują, że w polityce publicznej nabierać będą znaczenia kwestie związane z twardą formą stakeholder marketing. Wraz z procesami globalizacji i rosnącymi wpływami organizacji gospodarczych społeczeństwo oczekiwać będzie większej ich odpowiedzialności za podejmowane działania i ponoszenie kosztów stanowiących konsekwencję tych działań. W rezultacie mechanizmy i procesy polityki publicznej staną się siłą neutralizującą naturalną niechęć organizacji marketingowych do zmian zasad działania, włączając $\mathrm{w}$ to odchodzenie od miękkiej formy orientacji względem interesariuszy. Przyniesie to wiele zmian w polityce publicznej, która obok realizacji celów gospodarczych, powinna zagwarantować realizację celów społecznych i środowiskowych [Bhattacharya 2010, s. 1-3]. Można się więc spodziewać, że w prowadzonych dyskusjach na temat polityki publicznej istotną kwestią stanie się rozumienie wspólnego dobra społecznego, a także poszukiwanie sposobów jego pomiaru. Dyskusje te będą miały istotny wpływ na zmiany praktyk marketingowych. 


\subsection{Marketing relacji w sektorze publicznym}

Specyfika sektora publicznego sprawia, że wykorzystywane narzędzia i instrumenty marketingowe muszą być dostosowane do konkretnego modelu zarządzania publicznego. Dla rozwijającego się obecnie modelu Public Governance bardziej odpowiedni jest marketing relacji, bowiem w lepszym stopniu potrafi uwzględnić złożoność relacji, jakie zachodzą w tym sektorze. Atrakcyjność marketingu relacji sprawia, że w ostatnich latach podejmowane są próby jego dostosowywania do specyfiki organizacji publicznych [Knox, Gruar 2007, s. 115-135]. Owocuje to relacyjnym podejściem do rozwiązywania problemów w sektorze publicznym.

Złożoność powiązań między organizacjami publicznymi sprawia, że wykorzystanie koncepcji marketingu relacji w sektorze publicznym nie będzie łatwe. Dla podnoszenia swojej efektywności organizacje powinny się coraz bardziej otwierać na interakcje z podmiotami zewnętrznymi. Muszą nauczyć się zarządzania relacjami z partnerami publicznymi i prywatnymi, dążąc do wykorzystywania na rzecz społeczeństwa posiadanych przez nie zasobów. Wszystkie te podmioty mają jakiś wpływ na rozwój miasta czy regionu, zaś władza terytorialna może aktywnie działać na rzecz wykorzystywania potencjału tych podmiotów dla rozwoju całego obszaru (strategie mobilizowania) [Rudolf, Karpińska 2005, s. 694]. Działania takie mogą okazać się jednak trudne, z powodu zróżnicowanego charakteru wspomnianych relacji.

Tacy autorzy, jak Osborn, McMillan i Chew, zainspirowani klasyfikacją relacji w marketingu przedsiębiorstw Morgana i Hunta [1994], zaproponowali trzy następujące rodzaje marketingu relacji w organizacjach publicznych [Osborne, McMillan, Chew 2010, s. 191]:

- relacja organizacja publiczna-klient (usługi publiczne),

- relacja organizacja publiczna-interesariusze instytucjonalni (współpraca $z$ interesariuszami instytucjonalnymi),

- relacja organizacja publiczna-społeczeństwo (marketing polityczny).

Podział ten wydaje się uzasadniony, porządkujący potencjalne spektrum wykorzystania marketingu relacji w sektorze publicznym. Relacja organizacja publiczna-klient to bliska współpraca z odbiorcami usług publicznych, których świadczenie leży w kompetencji gminy, powiatu i województwa. Relacja organizacji publicznej z jej interesariuszami instytucjonalnymi koncentruje uwagę na działaniach związanych z przenikaniem i utrzymywaniem granic organizacji, co jest ważne dla międzyorganizacyjnego współdziałania. Władze publiczne każdego szczebla muszą odnaleźć się wśród zewnętrznych interesariuszy (publicznych, 
społecznych, prywatnych) i dążyć do wykorzystania posiadanych przez nich zasobów, by pełniej realizować swoje cele. Natomiast relacja organizacja publiczna-społeczeństwo jest związana $\mathrm{z}$ potencjalnym zaangażowaniem mieszkańców w tworzenie polityk publicznych oraz w proces ich wdrażania jako aktorów świadomych i kompetentnych, nie zaś pasywnych uczestników tych procesów.

Biorąc pod uwagę wcześniejsze rozważania, można zauważyć, że dotychczas najszerzej wykorzystywano marketing na poziomie świadczenia usług publicznych. Stosowanie procedur marketingowych dla usprawniania usług publicznych dobrze wpisuje się w filozofię promowaną przez model NPM. Współcześnie więcej uwagi należy poświęcić relacjom organizacji publicznej, zwłaszcza tej o charakterze terytorialnym, z innymi organizacjami, głównie interesariuszami instytucjonalnymi oraz relacjom ze społeczeństwem w ogóle. Są to równocześnie obszary niedostatecznie spenetrowane przez specjalistów od marketingu. Niepokojące w tym kontekście jest to, że obecnie to politolodzy oraz specjaliści z zakresu administracji rozwijają problematykę relacji międzyorganizacyjnych oraz sieci powiązań, co powinno być udziałem specjalistów od marketingu. Tym ważniejsze jest odnalezienie w tych nowych obszarach/dyscyplinach miejsca dla nowoczesnego marketingu. Kluczem do skutecznych działań w pluralistycznym państwie może być zatem efektywne współrządzenie (governance) poprzez mechanizmy bazujące na zaufaniu, takie jak marketing relacji czy marketing interesariuszy.

O ile model Public Governance został już koncepcyjnie szeroko opisany, o tyle nadal znacznie skromniej przedstawia się jego sfera narzędziowa. W tej sytuacji marketing, a w szczególności marketing relacji, może się stać potencjalną metodą działania organizacji publicznej, wpisując się w ramy modelu PG. Marketing relacji w sektorze publicznym koncentruje się na budowaniu relacji, których kluczowym wymiarem jest zaufanie. To właśnie zaufanie ułatwia sfinalizowanie wymiany w ramach danej relacji i stanowi bazę wspólnego zaangażowania w przedsięwzięcia korzystne dla obu stron.

Problem zaufania zajmuje ważne miejsce w koncepcjach B. Donaldsona i T. O’Toole, którzy opowiadają się za holistycznym zarządzaniem relacjami. $\mathrm{W}$ procesie tym ważne miejsce powinien zajmować tzw. kapitał relacyjny (relational capital) [Donaldson, O’Toole 2002]. Pojęcie to należy rozumieć jako: „poziom wzajemnego zaufania, szacunku oraz przyjaźni, jaka wytwarza się w wyniku bliskiej interakcji poszczególnych osób reprezentujących organizacje uczestniczące we wzajemnych powiązaniach" [Kale, Singh, Perlmutter 2000, s. 218]. Warto zwrócić uwagę na relacje indywidualnych osób, których jakość przekłada się później na efektywność interakcji międzyorganizacyjnych. 
Charakter współczesnego (pluralistycznego) państwa sprawia, że marketing może być bardzo przydatny przy podejmowaniu strategicznych decyzji związanych ze współpracą zewnętrzną danej organizacji. Kluczowe kompetencje menedżerów publicznych to zdolność dokonywania strategicznych wyborów dotyczących zakresu i charakteru relacji międzyorganizacyjnych. Do tego marketing relacji powinien okazać się bardzo przydatny. Menedżerowie ci, ale również pracownicy liniowi organizacji publicznych, powinni wykorzystywać takie relacje i starać się nimi aktywnie zarządzać, w przeciwnym razie suma korzyści płynących ze współpracy zewnętrznej może być niższa niż związane z tym koszty [Osborne, McLaughlin, Chew 2010, s. 195].

Koncepcja marketingu relacji, zdaniem T. Żabińskiej, dobrze wpisuje się w funkcjonowanie organizacji nowego typu, gdzie praca organizowana jest wokół procesów i realizujących je zespołów. Oznacza to odejście od klasycznej struktury funkcjonalnej i delegowanie decyzji oraz odpowiedzialności, a także kontroli w ręce osób realizujących dany proces [Żabińska 2000, s. 58]. Organizacja widziana przez pryzmat sieci relacji z różnymi podmiotami posiada rozmyte granice. Można ją określić jako „system, w ramach którego kluczowe zasoby, procesy i aktorzy funkcjonują i są zarządzani w sposób, który wykracza poza formalne struktury organizacyjne i oficjalną sprawozdawczość finansową" [Hendberg et al. 1994, s. 16; cyt. za Mitręga 2005]. Jeśli wcześniej struktury takie można było spotkać głównie w sektorze prywatnym, to obecnie coraz częściej występują one również w sektorze publicznym.

Od pewnego czasu zaobserwować można wzrost zainteresowania w sektorze publicznym problematyką współpracy międzyorganizacyjnej. Duże zasługi na tym polu ma Unia Europejska, która poprzez polityki publiczne definiowane na poziomie wspólnotowym promuje zasadę partnerstwa, czego przykładem jest tworzenie i realizacja polityki spójności. W tym kontekście marketing interesariuszy z perspektywy organizacji publicznej, a zwłaszcza organizacji terytorialnej, wydaje się koncepcją wartą uwagi. Jak pisze J. M. Bryson [2004], sukces organizacji publicznej zależy od umiejętności usatysfakcjonowania kluczowych jej interesariuszy, zaś analiza ich interesów może pomóc w podnoszeniu sprawności osiągania celów przez te organizacje.

Powyższe rozważania wskazują na potrzebę opracowania modeli zarządzania relacjami dla różnych systemów (np. lokalnych, regionalnych), sektorów usług (np. publicznej służby zdrowia, sektora społecznego, kultury, edukacji publicznej), czy szerzej, sfer publicznych z uwzględnieniem specyficznych ich uwarunkowań. Kluczową ich cechą powinna być umiejętność kreowania relacji z innymi interesariuszami oraz uzna- 
nie zasadniczej roli zaufania, będącego niezbędnym elementem każdej z nich. Należy równocześnie zdawać sobie sprawę, że zaufanie do organizacji publicznych nie jest jeszcze w Polsce na tyle wysokie, że można na nim opierać strategie wzmacniania relacji. W takich sytuacjach marketing, poprzez procesy współdziałania między organizacjami, może neutralizować napięcia i starać się doprowadzić do rezultatów korzystnych dla wszystkich stron.

\subsection{Podsumowanie}

W rozdziale zostały zaprezentowane wyniki badań bibliometrycznych, dzięki którym wykazaliśmy ogromny wzrost popularności problematyki rynku w piśmiennictwie dotyczącym działalności sektora publicznego. Największe natężenie tego zjawiska nastąpiło w połowie lat 90 . XX w. Natomiast $\mathrm{w}$ ostatniej dekadzie mamy do czynienia $\mathrm{z}$ zahamowaniem tendencji wzrostowej i jej stabilizacją. Oznacza to, że podejście rynkowe (marketingowe) zaczęło się pojawiać i rozwijać wraz z zaistnieniem nowych modeli zarządzania publicznego - zarówno w obszarze kreowania polityki publicznej, jak i świadczenia usług publicznych. Marketing klasyczny może być bowiem stosowany przez organizacje publiczne funkcjonujące w środowisku konkurencyjnym.

Dotychczasowe doświadczenia dotyczące wykorzystania marketingu w sektorze publicznym wskazują, że ma on najszersze zastosowanie w organizacjach terytorialnych. Autor prezentuje pogląd, że w Polsce mamy do czynienia $\mathrm{z}$ dynamicznym rozwojem marketingu terytorialnego, głównie w jego sferze narzędziowej. Odnosi się to przede wszystkim do problematyki budowania marki terytorialnej. Nadal istnieje deficyt ujęć koncepcyjnych, adekwatnych do sektora publicznego.

Starsze publikacje $\mathrm{z}$ zakresu marketingu w sektorze przedsiębiorstw podkreślały jego transakcyjny charakter (koncentrację na jednorazowych relacjach typu dostawca-klient), podczas gdy relatywnie nowsze opracowania więcej uwagi poświęcają innym relacjom. Stopniowo nabierało znaczenia budowanie relacji długookresowych nie tylko z klientem, lecz także $\mathrm{z}$ podmiotami $\mathrm{z}$ otoczenia przedsiębiorstwa. To dojrzewanie marketingu relacji ma związek z uświadomieniem sobie faktu, że na wartość oferowaną klientowi wpływają też interesariusze firmy. Często bowiem dostawca dóbr czy usług nie jest w stanie zaoferować klientowi odpowiedniej ich wartości i dopiero współdziałanie z interesariuszami przyczynia się do jej zwiększenia. 
W sektorze publicznym marketing relacji może być wykorzystywany w trzech obszarach (relacjach), takich jak: (1) organizacja publicznaklienci dla usług publicznych, (2) organizacja publiczna-interesariusze instytucjonalni, (3) organizacja publiczna-społeczeństwo. W niniejszej monografii będziemy eksplorować tę drugą relację, zawężając ją do relacji $\mathrm{w}$ wymiarze organizacyjnym: terytorium-interesariusze instytucjonalni. Przegląd literatury krajowej i zagranicznej na temat marketingu terytorialnego potwierdza tezę, że obszar wykorzystania marketingu w odniesieniu do miasta, regionu czy kraju jest nadal słabo rozpoznany, zaś autorzy w niewystarczający sposób nawiązują do teorii ekonomicznych, które mogą poszerzyć zakres tej koncepcji. 



\section{Rozdział 3}

\section{Rozwój relacji międzyorganizacyjnych w sektorze publicznym}

Prezentowany w rozdziale pierwszym proces ewolucji zarządzania publicznego wskazuje wyraźnie na rosnącą w nim rolę relacji międzyorganizacyjnych. Pewne ich elementy można było już zauważyć w modelu NPM, gdzie adaptowany z sektora prywatnego mechanizm rynkowy był wzbogacany tego rodzaju relacjami. Dopiero jednak w modelu Public Governance relacje takie zyskały na znaczeniu, zaś w niektórych krajach stały się nie tylko rozpoznawalne, lecz nawet dominujące. Może się nasuwać pytanie o przyczyny rosnącej popularności takich relacji. Z pewnością ma na to wpływ wzrost poziomu wykształcenia obywateli czy szerzej - poziomu ich dobrobytu społecznego, który skutkuje wzrostem ich aspiracji, a więc i potrzeb (tzw. potrzeb wyższego rzędu), jakie sektor publiczny powinien zaspokajać. Wywołuje on również potrzebę wchodzenia w różnego rodzaju alianse czy partnerstwa, zarówno indywidualnych osób, jak i organizacji.

Wiele wskazuje jednak na to, że główną przyczyną szybkiego rozwoju relacji międzyorganizacyjnych jest konieczność pozyskiwania zasobów, którymi sektor publiczny nie dysponuje lub dysponuje w niewystarczającym stopniu. Sytuacja taka przynosi nowe zadania dla organizacji publicznych, które muszą pozyskiwać zasoby, by osiągnąć stawiane przed nimi cele. Wchodzą więc one $\mathrm{w}$ relacje $\mathrm{z}$ tymi wszystkimi, którzy są w posiadaniu zasobów, względnie mają nad nimi kontrolę. Teoretyczną podstawę dla tego rodzaju działań stanowi teoria zależności od zasobów. Rozdział ma na celu określenie roli i znaczenia relacji partnerskich dla rozwoju regionu oraz pokazanie bogactwa tego rodzaju relacji w sektorze publicznym. 


\subsection{Rola partnerstwa w rozwoju terytorialnym}

Relacje międzyorganizacyjne, w tym relacje międzysektorowe, są stałym elementem procesu rozwoju lokalnego i regionalnego w praktyce krajów wysoko rozwiniętych. Podmioty sektora publicznego, jako jednostki planujące, regulujące, dostarczyciele zasobów i czynników produkcji, zawsze działały blisko sektora prywatnego (deweloperów, instytucji finansowych, pracodawców, dostarczycieli usług). Równolegle potrzeby społeczności lokalnych zaczęły być brane pod uwagę przez instytucje demokracji lokalnej i przez inne podmioty (np. NGO).

Rozwój można ogólnie rozumieć jako pożądane, pozytywne zmiany ilościowe, jakościowe i strukturalne danego układu. Wyjaśnienie to jest bardzo pojemne i dobrze oddaje istotę tego pojęcia. W dalszych rozważaniach koncentrować się będziemy na rozwoju lokalnym i regionalnym. Na początek odwołajmy się do definicji R. Brola, która wydaje się klasycznym ujęciem tego terminu. Zdaniem tego autora rozwój lokalny to

zharmonizowane i systematyczne działania społeczności lokalnej, władzy lokalnej oraz pozostałych podmiotów funkcjonujących w gminie, mających na celu kreowanie nowych i poprawę istniejących walorów użytkowych gminy [Brol 1998, s. 121-122].

Warto zwrócić uwagę na kilka elementów tego objaśnienia. Wymienia się w nim szereg podmiotów, które mają prowadzić politykę rozwoju terytorium, a mianowicie władze samorządowe oraz inne podmioty, a nawet całą społeczność lokalną. W definicji zawarty jest również cel działania tych podmiotów w ramach rozwoju lokalnego, czyli tworzenie i poprawa walorów użytkowych gminy. Można dodać, że chodzi o szeroko rozumianą kategorię jakości życia, która ma ogromny wpływ na konkurencyjność danej przestrzeni.

W podobny sposób, chociaż bardziej ogólnie, wyjaśnia rozwój lokalny L. Wojtasiewicz, dla której „to proces zmian, zachodzących w danym układzie lokalnym, z uwzględnieniem właściwych temu układowi potrzeb, preferencji i hierarchii wartości” [Wojtasiewicz 1996, s. 14]. Nieco szerszą definicję rozwoju lokalnego przytacza A. Jewtuchowicz, której zdaniem jest to „proces zróżnicowania i wzbogacania działalności ekonomicznych i społecznych na określonym terytorium, polegający na mobilizacji i koordynacji własnych zasobów i energii" [Jewtuchowicz 2013, s. 58]. W obu tych definicjach rozwój ograniczony jest do jakiegoś miejsca, jest związany z konkretną przestrzenią. Jewtuchowicz zaś wskazuje dodatkowo na sposób realizacji rozwoju poprzez mobilizację i koordynację posiadanych zasobów oraz energii. 
W ostatnich latach rośnie w Polsce zainteresowanie rozwojem na poziomie regionu, bowiem ten szczebel samorządu terytorialnego zyskuje coraz większe kompetencje i odgrywa coraz ważniejszą rolę w rozwoju społeczno-gospodarczym kraju. Prowadzone na ten temat badania generalnie zmierzały do przełamania aprzestrzenności teorii ekonomicznych. $\mathrm{W}$ ten nurt wpisuje się tzw. nowa geografia ekonomiczna oraz powiązane z nią nurty badań ekonomii miejsc i ekonomii przepływów ${ }^{1}$. Analizy te przyniosły w rezultacie dowartościowanie wymiaru terytorialnego (regionalnego, przestrzennego) procesów rozwojowych.

Jak zauważa J. Szlachta [2011, s. 25-26], to nowe podejście zaczęło w ostatnich latach przenikać do polityki spójności formułowanej na szczeblu unijnym. To właśnie Unia Europejska, dzięki zapisom Traktatu z Lizbony, przyczyniła się w ostatnich latach do wyeksponowania wymiaru terytorialnego w polityce rozwoju, realizowanej na szczeblu narodowym oraz na szczeblach regionalnych i lokalnych. W dokumencie tym czytamy, że: „UE wspiera spójność gospodarczą, społeczną, terytorialną oraz solidarność między państwami członkowskimi” [Barcz 2008]. Traktat zmienił pozycję prowadzonej na szczeblu unijnym polityki rozwoju, nazwanej polityką spójności, uzupełniając jej dotychczasowe wymiary, gospodarczy i społeczny, wymiarem terytorialnym.

Rozwój wspomnianych relacji międzyorganizacyjnych zaowocował pojawieniem się nowych ich form. Stanowiły one rezultat rosnącej złożoności otoczenia instytucjonalnego oraz nowych zasad zarządzania publicznego. Jedną z takich form jest partnerstwo (partnership), które M. Geddes [2008, s. 205] określa jako relację wielu partnerów współpracujących ze sobą, gdzie pojedynczy podmiot nie jest jednostką dominującą. Należy podkreślić, że tak rozumiane partnerstwa lokalne i regionalne zaczęły się dynamicznie rozwijać w latach 80 . i 90. XX w. oraz na początku XXI w. Bezpośrednią tego przyczyną były przemiany w koncepcjach ekonomicznych, które wywierały istotny wpływ na politykę gospodarczą w poszczególnych krajach.

Początkowo relacje między państwem i rynkiem były raczej klarowne. Sektor prywatny był odpowiedzialny za gospodarkę (produkcję), podczas gdy państwo gwarantowało bezpieczeństwo i zabezpieczenie społeczne. Obywatele byli albo pracownikami, albo odbiorcami usług społecznych [Geddes 2008 s. 205]. Kryzys fordyzmu i keynesizmu zakwestionował taki podział. Kryzysy gospodarcze zmusiły przedsiębiorstwa do restrukturyzacji ich działalności, co przyczyniło się do rozwoju miast i regionów.

1 Za prekursora tego podejścia przyjmuje się amerykańskiego ekonomistę P. Krugmana, który w 1991 r. jako pierwszy przedstawit model ogólnej równowagi przestrzennej alokacji aktywności ekonomicznej [Nowińska-Łaźniewska 2004, s. 40]. 
Natomiast krytyka państwa dobrobytu oparta na ideologii keynesowskiej stworzyła klimat dla redukcji wydatków publicznych oraz prywatyzacji usług publicznych. Sprawiło to, że granice pomiędzy sektorem publicznym i prywatnym stały się mniej wyraźne. Dokonujące się procesy liberalizacji i rosnąca rola rynku w latach 80 . i 90 . XX w. przyczyniły się do stworzenia formuly partnerstwa publiczno-prywatnego. Od tego czasu formuła ta rozwija się w różnym tempie, zakresie i skali w poszczególnych krajach, wszędzie jednak miała pozytywny wpływ na rozwój lokalny i regionalny.

Przyjrzyjmy się bliżej zasadom partnerstwa. Warto zauważyć, że zarówno zakres kompetencji, jak i odpowiedzialności partnerów może być różny. Niektóre partnerstwa mają bardziej strategiczne zadania, podczas gdy inne skupiają się raczej na kwestiach operacyjnych. W związku z tym jedne zajmują się formułowaniem polityk i budowaniem strategii, a drugie skupiają się na ich implementacji. Coraz więcej układów partnerskich posiada szerokie spektrum zadań, wychodzących poza zakres programów lokalnych. Prowadzą one rozległe działania, obejmujące swoim zasięgiem inne terytoria. Partnerstwa różnią się między sobą, także ze względu na okres ich działalności. Część z nich powoływana jest do realizacji określonego zadania, po czym ulega rozwiązaniu. Inne mają charakter bardziej trwały i stanowią ważny element otoczenia instytucjonalnego.

Zróżnicowane są ponadto zasoby, jakimi dysponują partnerstwa, zaś różnice dotyczyć mogą ich rozmiarów, ich dostępności, ich źródeł czy ich natury. Wiele partnerstw szeroko wykorzystuje rządowe strumienie finansowe i jest od nich całkowicie lub w znacznym stopniu zależna. W niektórych przypadkach partnerstwa są powoływane do życia, aby administrować tego rodzaju funduszami. Istnieją również partnerstwa, których działalność jest finansowana ze środków pozyskanych na szczeblu lokalnym. Wskazać można pewną zależność między rodzajem finansowania a rodzajem ich działalności. Partnerstwa ukierunkowane na rozwój gospodarczy zwykle dysponują większymi funduszami niż partnerstwa zajmujące się sprawami ubóstwa i społecznego wykluczenia. Ważne jest również, czy celem partnerstwa jest realizacja konkretnego programu, wykorzystującego zabezpieczone na ten cel środki, czy też środki na jego realizację są niedostateczne i zachodzi potrzeba ich przyciągania. Często również celem partnerstwa jest wywieranie wpływu na sposób wykorzystania przez partnerów zasobów będących w ich posiadaniu.

Stosunkowo wcześnie zasady partnerstwa były wykorzystywane w Wielkiej Brytanii, gdzie już w latach 70. XX w. znalazły zastosowanie w programach rewitalizacji (regeneration programmes). Początkowo partnerstwo takie polegało na tworzeniu więzi partnerskich pomiędzy 
rządem centralnym oraz władzami lokalnymi i stanowiło ważny element realizowanego w tym kraju programu Inner City Partnership Programme [Roberts et al. 1995]. Taka koncepcja partnerstwa była charakterystyczna dla tzw. starego rządu laburzystów. Inne podejście zastosował rząd konserwatywny pod przewodnictwem Margaret Thatcher. Pojawily się wtedy nowe rozwiązania, takie jak: Urban Development Corporations czy Enterprise Zones. Ograniczona została natomiast rola władzy lokalnej oraz sektora społecznego (NGO), który sprowadzono do pozycji podrzędnej. Kolejne rządy reprezentowały bardziej pluralistyczne podejście do partnerstwa, ale dopiero ponowne rządy Partii Pracy przyniosły rozwój partnerstwa zarówno przy rewitalizacji, jak i ochronie zdrowia, edukacji itp.

W innych krajach europejskich popularyzację zasad partnerstwa wymuszała głównie polityka UE, która była realizowana już na początku lat 80. XX w., kiedy to promowano współpracę partnerów społecznych w ramach poszczególnych krajów, a więc państwa, organizacji pracodawców oraz związków zawodowych [Andersen, Mailand 2002]. Natomiast pod koniec okresu, gdy tworzono politykę regionalną na poziomie Wspólnoty, partnerstwo stało się jedną z zasad tej polityki [Rudolf 2006c]. Polityka ta, nazwana później polityką spójności UE, polegała na promowaniu współpracy zarówno w rozwoju regionalnym, jak i w działaniach na rzecz przeciwdziałania ubóstwu i społecznemu wykluczeniu (np. programy Poverty, Urban).

Partnerstwo stanowiło warunek otrzymania wsparcia z Funduszy Europejskich, dlatego stało się skutecznym instrumentem wpływu UE na politykę krajów członkowskich. Dotyczyło to zwłaszcza tych państw, które w pierwszych latach prowadzonej polityki regionalnej na poziomie wspólnotowym stały się jej poważnymi beneficjentami. Zaproponowany przez Komisję Europejską model partnerstwa został wykorzystany w narodowych programach rozwoju takich krajów, jak: Irlandia, Hiszpania czy Portugalia. W krajach skandynawskich, które w ograniczonym zakresie były beneficjentami europejskiej polityki spójności, promowano lokalne partnerstwo poprzez rozwijanie istniejących struktur demokratycznych [Geddes, Benington 2001]. Budowanie standardów partnerstwa obserwujemy również w krajach Europy Środkowo-Wschodniej, szczególnie od czasu ich przystąpienia do UE w 2004 r. W świetle powyższych faktów, trudno przecenić wkład Unii Europejskiej w rozwój partnerstwa.

Pewien wpływ na rozwój partnerstwa posiada również OECD. Jest to organizacja, która promuje partnerskie modele polityki rozwoju nie tylko w krajach europejskich, lecz także w wielu innych krajach członkowskich (np. w Meksyku czy Australii). Warto wspomnieć, że partnerstwo, jako mechanizm polityki rozwoju, rozwijane jest też w krajach, które 
najwcześniej zaczęły stosować jego zasady. Wymienić tu można wspominaną już Wielką Brytanię, prowadzącą dialog z innymi państwami Commonwealth (np. Australią czy Nową Zelandią), który zaowocował transferem brytyjskiego modelu partnerstwa. Dodajmy, że Wielka Brytania jest otwarta na partnerskie rozwiązania z innych krajów Commonwealth.

Stosunkowo wcześnie, bo już w latach 50. i 60. XX w. ukształtowało się partnerskie podejście do polityki rozwoju w USA. Doświadczenia amerykańskie są jednak trudniejsze do popularyzacji ze względu na pewną specyfikę funkcjonujących tam rozwiązań. Przejawia się ona m.in. w następujący sposób [Stone 1989, 1993]:

1. W odróżnieniu od krajów europejskich dominują tam głównie struktury współpracy o niewielkim stopniu formalizacji, szczególnie pomiędzy reprezentantami sektora gospodarki a lokalnymi elitami (np. urban regimes czy growth coalitions).

2. Na rozwój partnerskich relacji wpływały skutecznie władze federalne, finansując programy o istotnym znaczeniu dla rozwoju społeczności poprzez partnerską współpracę podmiotów lokalnych. Dotyczyło to np. takich partnerów lokalnych, jak: agencje stanowe, przedsiębiorstwa, organizacje typu NGO. Wśród takich programów wymienić należy Urban Enterprise Zones (lata 80. i 90. XX w.) oraz bardziej zorientowany na społeczność lokalną Empowerment Zones (od lat 90. XX w.).

3. USA to federacja o dużym zróżnicowaniu poszczególnych stanów. Zróżnicowanie to dotyczy również podejścia do partnerstwa. Wykształciły się więc różne jego formy w poszczególnych stanach, w przeciwieństwie do krajów Unii Europejskiej, gdzie zróżnicowanie to jest dużo mniejsze.

Szeroki rozwój partnerstwa sprawił, że stało się ono wyróżnikiem polityk na wszystkich szczeblach ich stanowienia (takich jak: globalny, regionalny - regiony świata, krajowy, federalny - regionalny, lokalny). Najbardziej wrosło ono w kulturę budowania i realizacji polityki rozwoju w: Wielkiej Brytanii, USA, starych krajach UE, a także Nowej Zelandii czy Australii. Natomiast w państwach, które przez dziesięciolecia funkcjonowały w warunkach gospodarki socjalistycznej, partnerstwo nie stanowi jeszcze oczywistej cechy rozwoju. W krajach Europy Środkowo-Wschodniej słabość instytucji państwa oraz słabość społeczeństwa obywatelskiego negatywnie wpływa na wykorzystanie potencjału partnerstwa [Geddes 2008, s. 209]. W Polsce jakość partnerstwa w rozwoju terytorialnym pozostaje jeszcze na niższym poziomie niż w krajach starej Piętnastki, gdzie zasada partnerstwa jest stosowana od 1989 r., kiedy po raz pierwszy uruchomiono politykę regionalną na poziomie Wspólnoty, a partnerstwo stało się jej podstawową zasadą. 
Rodzimi naukowcy od początku byli jednak przekonani co do zasadności stosowania partnerskiego podejścia w procesach rozwojowych. Zwolennikiem relacji partnerskich jest m.in. S. Korenik [2011, s. 67], który uważa, że sieci partnerów umożliwiają pełniejsze wykorzystanie posiadanych zasobów oraz tworzą nowe możliwości rozwoju. Jak pisze, ułatwiają one realizację tych procesów, zwiększają skalę realizowanych przedsięwzięć, zwiększają gwarancje ich skuteczności itp. Zwraca jednocześnie uwagę na ich wady. Twierdzi przykładowo, że sieci nie są sprawiedliwe ani demokratyczne i daleko im do ideału oraz norm etycznych. Ponadto w sieciach największe korzyści odnoszą zazwyczaj najsilniejsi, którzy często sami te sieci tworzą. Według tego autora zauważyć można w ostatnim czasie istotne zmiany w realizacji procesów społeczno-gospodarczych w regionie:

obecnie podstawą stają się przedsięwzięcia o charakterze kreatywnym, niosące w sobie duży element innowacyjności. Zagrożenie niesie rutyna, która powoduje, że powtarzalne działania nie są dostosowane do zmieniających się warunków $[\ldots]$. Nie bez znaczenia jest przy tym kooperacja różnych jednostek i osób, gdyż rozwiązania kreatywne, innowacyjne powstają w procesie wieloaspektowej interakcji [Korenik 2011, s. 67].

Jego zdaniem region posiada odpowiednie warunki do innowacyjnego rozwoju zarówno ze względu na bliskość położenia czy związki kulturowe, jak i podobne wartości czy zaufanie.

Na potrzebę rozwijania relacji partnerskich wskazuje także A. Jewtuchowicz. Twierdzi ona, że

sieci są zbiorami wyselekcjonowanych związków z wybranymi partnerami, wpisującymi się w relacje rynkowe przedsiębiorstw. Są one efektem poszukiwania komplementarnych zasobów, a głównym motywem powstawania sieci jest synergia i dążenie do zmniejszenia niepewności działania. Powiązania w sieci są elastyczne i mogą tworzyć różne kombinacje. Nie są one zdefiniowane a priori, ich powstanie wynika ze strategii partnerów [Jewtuchowicz 2001, s. 82].

Na podkreślenie zasługują motywy powstawania sieci. Pierwszy z nich to efekt synergii, towarzyszący zwykle działalności zespołowej. Może o nim zdecydować swobodny dobór partnerów, ponieważ sieć to zespół autonomiczny, tworzony na zasadach dobrowolności. Warto zwrócić uwagę na drugi ważny motyw, a mianowicie dążenie do zmniejszenia niepewności. Jest to generalnie motyw tworzenia każdej instytucji. Budowanie sieci może zapewnić przewidywalność podejmowanych przez partnerów działań i wzrost zaufania między nimi. 
Rozwój partnerskiego współdziałania w regionie wymaga od decydentów znajomości cyklu rozwojowego stosunków partnerskich [Szromnik 2004, s. 287]. Punktem wyjścia jest tu identyfikacja problemu i identyfikacja spodziewanych korzyści dla jednostek terytorialnych, które stać się mogą ich udziałem w przypadku rozwiązania problemu. Następna faza obejmuje analizę urzędu marszałkowskiego, regionów konkurencyjnych oraz głównych kontrahentów pod kątem ich udziału w rozwiązywaniu problemu, z uwzględnieniem sił i środków niezbędnych do tego celu. Analiza taka powinna wyłonić potencjalnych partnerów do współpracy przy jego rozwiązywaniu.

Kluczowym elementem będzie tu określenie założeń strategii partnerstwa, a także jej cech oraz wyznaczników. Ważnym etapem rozwoju partnerstwa będzie określenie zbioru instrumentów partnerskiego marketingu mix oraz jego wdrożenie w postaci wspólnych przedsięwzięć, kampanii czy prowadzonych działań. Ostatni etap to analiza i ocena osiągniętego poziomu zaangażowania i rozwoju partnerstwa oraz odniesienie go do założonych celów. Praktyka przynosi szereg interesujących przykładów świadczących o tym, że wspomniana strategia partnerskiego współdziałania staje się faktem i może przynosić wymierne korzyści [Kaźmierczak, Hernik 2008].

\subsection{Rodzaje relacji międzyorganizacyjnych i ich rozwój}

Relacje międzyorganizacyjne określa się w literaturze na wiele sposobów, biorąc przy tym pod uwagę ich zakres, intensywność, trwałość itp. Za wartościową należy uznać klasyfikację J. M. Brysona i B. C. Crosbiego [2008, s. 56], którzy dokonali podziału tych relacji na cztery poziomy, takie jak: współpraca (cooperation), koordynacja (coordination), współdziałanie (collaboration) oraz integracja (merger) ${ }^{2}$. Za kryterium takiego podziału przyjęto rosnący udział partnerów w podejmowaniu decyzji. Poziomy te, wraz z odpowiadającym im udziałem w decyzjach, przedstawiono w tab. 3.1. Przy ich omawianiu za podstawę przyjęto terminy anglojęzyczne, gdyż polskie odpowiedniki nie do końca oddają ich istotę.

2 Podobną klasyfikację prezentują również: R. O'Leary, B. Gazley, M. McGuire, L. B. Bingham [2009, s. 5]. 
Tabela 3.1. Poziomy relacji międzyorganizacyjnych

\begin{tabular}{|c|c|c|c|c|}
\hline $\begin{array}{c}\text { Podstawa } \\
\text { relacji }\end{array}$ & \multicolumn{4}{|c|}{ Poziomy relacji } \\
\hline Władza & & & & \multirow{4}{*}{$\begin{array}{c}\text { integracja } \\
\text { (merger) }\end{array}$} \\
\hline $\begin{array}{l}\text { Potencjał } \\
\text { możliwości }\end{array}$ & & & \multirow{3}{*}{$\begin{array}{l}\text { współdziałanie } \\
\text { (collaboration) }\end{array}$} & \\
\hline $\begin{array}{l}\text { Działania } \\
\text { i zasoby }\end{array}$ & & \multirow[b]{2}{*}{$\begin{array}{l}\text { koordynacja } \\
\text { (coordination) }\end{array}$} & & \\
\hline $\begin{array}{l}\text { Informacja, } \\
\text { dobra wola } \\
\text { i dobre intencje } \\
\text { (np. unikanie } \\
\text { konfliktów) }\end{array}$ & $\begin{array}{l}\text { współpraca } \\
\text { (cooperation) }\end{array}$ & & & \\
\hline Brak & \multicolumn{4}{|c|}{ Brak mechanizmu partnerstwa } \\
\hline
\end{tabular}

Źródło: opracowanie na podstawie [Bryson, Crosby 2008, s. 56].

Najniższy poziom relacji partnerskich wspominani autorzy określają terminem cooperation (współpraca). Dla takich relacji podstawową rolę odgrywa dzielenie się informacjami. Termin ten będziemy rozumieć jako zdolność do prowadzenia wspólnych działań z innymi podmiotami (interesariuszami) dla osiągnięcia wspólnego celu bądź wspólnych korzyści [Bevir 2007, s. 153]. Działania te są podejmowane przez podmioty życzliwie do siebie nastawione, zwykle działające w dobrej wierze [Egan 2008, s. 4]. Relacje współpracy między podmiotami ograniczają zwykle konflikty między nimi, w każdym razie starają się ich unikać.

Kolejny, nieco wyższy poziom relacji międzyorganizacyjnych, to coordination (koordynacja). Dotyczy ona zarówno działań osób indywidualnych, jak i organizacji czy instytucji. Stanowi ważny element governance [Bevir 2007, s. 153]. Koordynacja wykorzystywana jest na różnych poziomach władzy oraz na styku funkcjonowania różnych podmiotów. Jej zasady mogą być ustalane na nieformalnych spotkaniach liderów albo mogą być określone w sposób formalny, np. przez lokalne stowarzyszenia nastawione na rozwiązywanie lokalnych problemów.

Można mówić ponadto o tzw. mechanizmach koordynacji, do których zaliczane są rynki, hierarchie (struktury) oraz sieci. W pierwszym przypadku kluczową rolę odgrywa cena. Jest ona mechanizmem równoważącym popyt z podażą i decydującym o relacjach między sprzedającymi i kupującymi. Hierarchia opiera się na mechanizmie nakazów oraz kontroli realizowanych zadań. Natomiast mechanizm sieci bazuje na 
zaufaniu. Obejmuje on podmioty, które niekiedy nie mają między sobą żadnych formalnych powiązań. Koordynacja to również mechanizm służący ujawnianiu i rozwiązywaniu konfliktów. Służy ustalaniu zależności służbowych, ułatwianiu komunikacji, upowszechnianiu się wiedzy i innowacji. Koordynacja prowadzi również do ograniczania oportunizmu³

Termin collaboration (współdziałanie) jest różnie rozumiany w poszczególnych krajach. W USA terminem tym określa się współdziałanie władz z partnerami publicznymi i prywatnymi (interesariuszami instytucjonalnymi) na różnych szczeblach [Agranoff, McGuire 2003]. W Wielkiej Brytanii natomiast jest używany w kontekście rozwoju lokalnego, zarządzania w sektorze publicznym oraz marketingu. R. Agranoff oraz M. McGuire definiują termin collaboration jako: „celową relację, zaprojektowaną z myślą o rozwiązywaniu problemów, poprzez znalezienie rozwiązania przy uwzględnieniu warunków brzegowych (wiedza, czas, pieniądze, konkurencja)" [Agranoff, McGuire 2003, s. 4].

Ostatni, najwyższy z wymienionych poziomów partnerstwa - merger (integracja) - sumuje wszystkie podstawy relacji z dotychczasowych poziomów, uzupełniając ich zakres o przejęcie kontroli (władzy) przez jednego z partnerów, co oznacza połączenie się organizacji i ich wewnętrzną integrację. Jak piszą Bryson i Crosby [2008, s. 56-57], warunkiem zaistnienia tych relacji pomiędzy organizacjami jest wzajemne zaufanie i rzetelna prezentacja swoich celów, zasobów oraz możliwości. W przypadku organizacji publicznych zaistnienie relacji na takim poziomie może być jednak jedynie konsekwencją decyzji administracyjnej. Zmiany kompetencyjne w zakresie zadań kierowanych do poszczególnych szczebli samorządu terytorialnego stanowiły np. w Polsce konsekwencję procesów decentralizacji i promowanej pośród krajów Unii Europejskiej zasady subsydiarności (pomocniczości).

W dalszych rozważaniach podjęto próbę ustalenia, na ile w literaturze naukowej, dotyczącej funkcjonowania sektora publicznego, była podejmowana szeroko rozumiana problematyka relacji międzyorganizacyjnych. W podobny sposób jak w rozdziale drugim poszukiwano w słowach kluczowych artykułów naukowych terminów kojarzonych

3 Zdaniem O. E. Williamsona, oportunizm stanowi powszechną cechę ludzkiej natury. Należy go rozumieć jako „przebiegłe dążenie do realizacji własnego interesu [...] odnosi się on do niekompletnego bądź zniekształconego ujawniania informacji, zwłaszcza do świadomie podejmowanych wysiłków, by wprowadzić w błąd, zniekształcić, zataić, zaciemnić lub pogmatwać sprawy w inny sposób" [Williamson 1998, s. 60]. Nie każde wykorzystywanie istniejących możliwości dla realizacji własnego interesu jest zachowaniem oportunistycznym. Z oportunizmem mamy do czynienia dopiero wtedy, jeśli przy realizacji własnego interesu jednostka bądź grupa narusza interes innych, działa na ich niekorzyść, uciekając się do podstępu, oszustwa bądź kłamstwa. 
z relacjami międzyorganizacyjnymi. Częstotliwość ich występowania może świadczyć o popularności tej problematyki, o jej natężeniu w poszczególnych okresach itp. Oprócz omawianych wcześniej takich terminów, jak: cooperation, coordination i collaboration, przedmiotem badania były również: relation, network oraz partnership, które zdaniem autora są szeroko stosowane do opisu występujących relacji. W badaniu pominięto omawiane wcześniej pojęcie merger, ze względu na niewielką jego popularność w analizowanym kontekście oraz wysokie prawdopodobieństwo różnej jego interpretacji przez badaczy sektora publicznego. Metodykę tego wątku badawczego opisano w rozdziale czwartym.

Zebrane na ten temat informacje zestawiono na rys. 3.1, 3.2 i 3.3. Zdecydowanie najczęściej w słowach kluczowych występował termin relation, bowiem w ciągu 20 lat został użyty aż 507 razy. Popularne były też pojęcia network oraz partnership, użyte odpowiednio 288 i 274 razy. Inne terminy, collaboration czy coordination, chociaż dużo mniej popularne (użyte odpowiednio 95 i 52 razy), to posiadają wysoką dynamikę wzrostu.

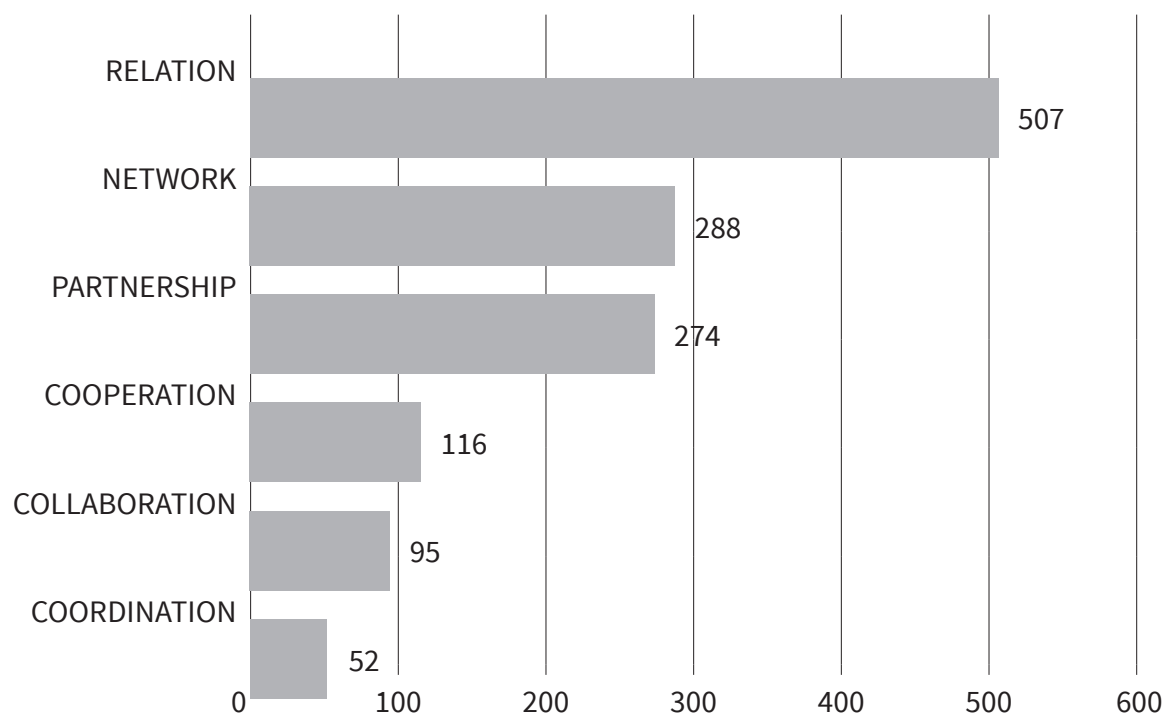

Rys. 3.1. Łączna liczba badanych terminów związanych z relacjami użytych w słowach kluczowych artykułów naukowych badanego zbioru czasopism z zakresu sektora publicznego w latach 1995-2014

Źródło: opracowanie własne na podstawie bibliometrycznych baz danych: Journal Citation Report (Web of Science) oraz SCOPUS (ELSEVIER).

Na szczególne podkreślenie zasługuje termin collaboration, którego dynamika była największa w porównaniu ze wszystkimi innymi badanymi pojęciami (rys. 3.2). Interesujące jest również to, że czasopisma naukowe, 
w których najczęściej stosowano słowo collaboration reprezentują różne specjalności $\mathrm{w}$ ramach sektora publicznego, takie jak: usługi społeczne ("Administration in Social Work"), politykę publiczną ("Policy Studies, Policy Studies Journal"), zarządzanie publiczne ("Public Management Review") oraz administrację publiczną ("American Review of Public Administration"). Świadczy to o uniwersalności tego terminu i wysokim potencjale rozwoju współdziałania w różnych obszarach sektora publicznego.

Warto zwrócić uwagę na rozproszenie analizowanych terminów w poszczególnych czasopismach. Najbardziej rozproszony był termin relation, ponieważ wystąpił w największej liczbie badanych czasopism. Najmniej rozproszony był natomiast termin cooperation. W tym przypadku niemal połowa jego zastosowań w słowach kluczowych została użyta zaledwie $\mathrm{w}$ trzech czasopismach (w "Climate Policy", "Public Administration" i "Science and Public Policy") spośród badanych czterdziestu sześciu. Niewątpliwie najpopularniejszym $\mathrm{z}$ analizowanych terminów był relation, którego częstość występowania w słowach kluczowych wzrosła w badanym okresie aż piętnastokrotnie. Relatywnie krótszą historię ma pojęcie network, które wykazało się jednak jeszcze większą dynamiką wzrostu w ciągu ostatnich 10 lat. Co prawda w roku 2014 odnotowano spadek tej dynamiki, ale dopiero kolejne lata pokażą, na ile tendencja ta okaże się trwała.

Praktycznie wszystkie poszukiwane terminy występowały w artykułach publikowanych w czasopismach reprezentujących trzy obszary tzw. administracji publicznej, czyli: politykę publiczną, administrację, zarządzanie publiczne. Można jednak i tu zaobserwować pewne prawidłowości. Czasopisma koncentrujące się na problemach polityki publicznej okazały się popularniejsze wśród autorów używających takich słów kluczowych do swoich tekstów, jak: coordination (np. w: "Journal of European Social Policy" (16,98\%), "Journal of Public Policy" (9,43\%), "Journal of European Public Policy" (7,55\%)) czy cooperation (np. w: "Climate Policy" (20\%), "Science and Public Policy" (10,83\%), "Policy Studies Journal” (7,50\%)).

Termin collaboration najczęściej pojawiał się w czasopismach podejmujących tematy zarządzania publicznego czy administracji, np. w "Administration in Social Work" (13,33\%), "Public Management Review" (12,38\%), "American Review of Public Administration" (9,52\%).

Ciekawych informacji dostarcza zestawienie częstości występowania terminów w słowach kluczowych artykułów opublikowanych w badanych czasopismach w okresach pięcioletnich, a także kształtowanie się trendów występowania tych pojęć. Informacje na ten temat zawierają załączniki 3.1 i 3.2. W każdym z pięcioletnich okresów termin relation był najczęściej wymieniany przez autorów badanych tekstów. O ile jednak we wcześniejszych okresach na drugiej pozycji plasował się termin partnership, to w latach 2011-2014 miejsce to z wysoką przewagą zajął network(s). 


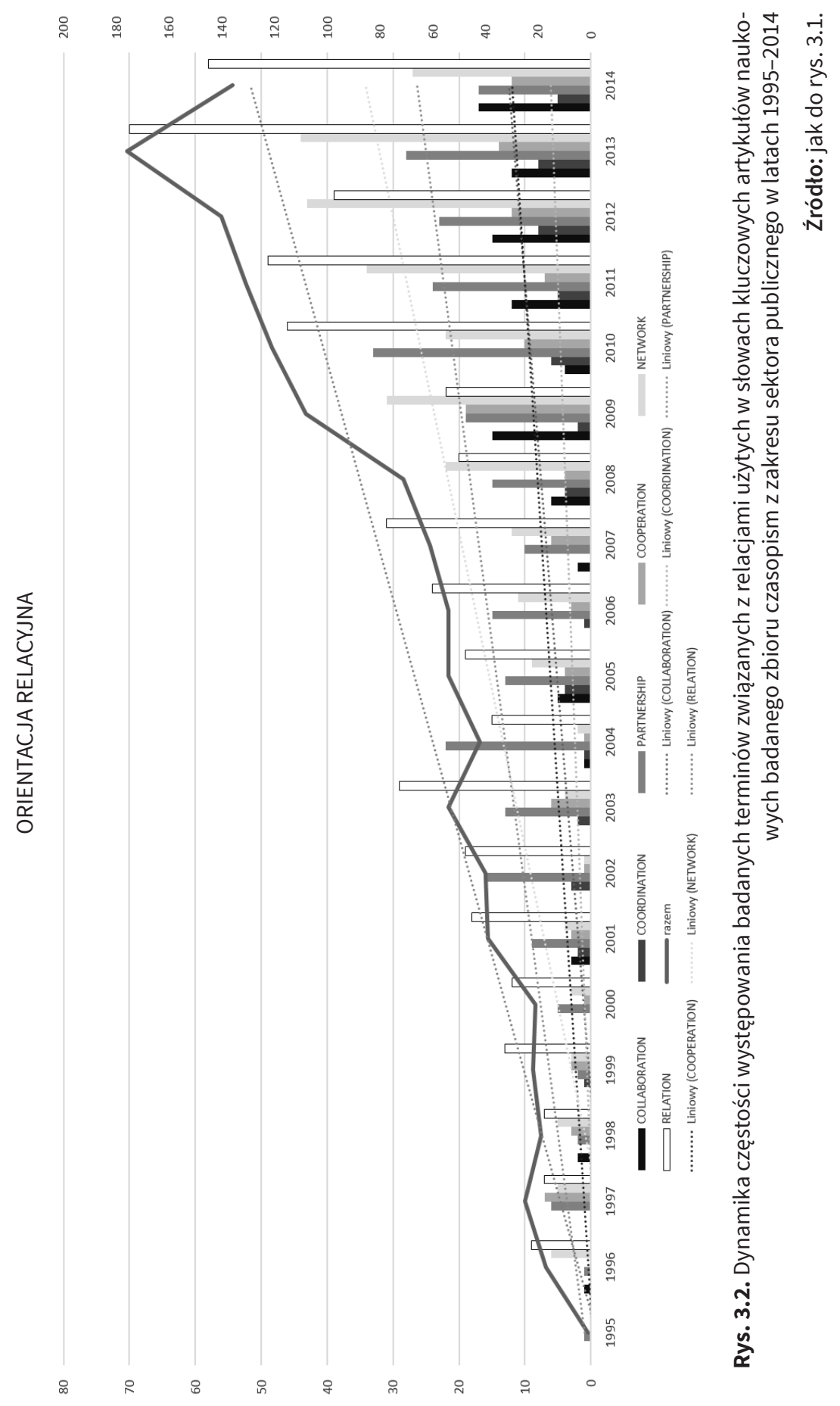


ORIENTACJA RELACYJNA

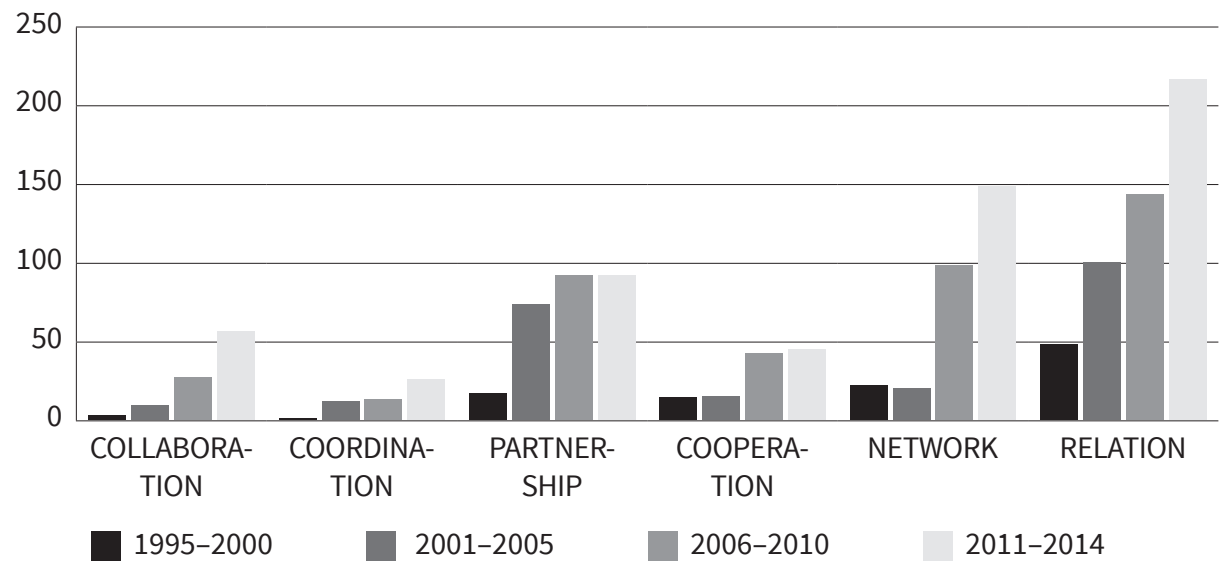

Rys. 3.3. Dynamika wzrostu częstości występowania badanych terminów związanych z relacjami użytych w słowach kluczowych artykułów naukowych badanego zbioru czasopism z zakresu sektora publicznego w latach 1995-2014 z podziałem na cztery okresy

Źródło: jak do rys. 3.1.

Podsumowując tę część rozważań, należy podkreślić, że w czołowych czasopismach naukowych z obszaru funkcjonowania sektora publicznego systematycznie rośnie popularność tematyki związanej z relacjami międzyorganizacyjnymi. Można jedynie przypuszczać, że zdecydowało o tym coraz większe zainteresowanie naukowym opisem zjawiska otwierania się organizacji publicznej na jej otoczenie podmiotowe. W zestawieniu $\mathrm{z}$ opisem popularności tematów badawczych dotyczących rynku w działalności organizacji publicznych (rozdział drugi) można wyciągnąć wniosek, że w ostatniej dekadzie autorzy zastępują wątek rynkowy wątkiem relacyjnym.

Dla określania relacji międzyorganizacyjnych na zaawansowanym poziomie przyjęto termin współdziałanie (collaboration). Jako uzasadnienie podać można, że autorzy, zwłaszcza w USA, ale też w Europie Zachodniej, stosują go do opisu relacji organizacji publicznych z ich interesariuszami instytucjonalnymi (publicznymi, prywatnymi i społecznymi). Coraz częściej używany jest również w dokumentach strategicznych polskich samorządów terytorialnych. Stanowi docelową, praktycznie najwyższą formę relacji pomiędzy organizacjami bez przeniesienia władzy. Współdziałanie występuje wtedy, jeśli odbywa się pomiędzy niezależnymi interesariuszami. Wypracowywanie przez nich rozwiązań dokonuje się poprzez uwzględnianie istniejących między nimi różnic. Współdziałające podmioty wspólnie przygotowują i podejmują decyzje oraz wspólnie ponoszą odpowiedzialność za obrany kierunek działań [Gray 1989, cyt. za: Agranoff, McGuire 2003]. 
Termin współdziałanie (collaboration) jest używany znacznie częściej w Stanach Zjednoczonych niż w krajach europejskich, gdzie bardziej popularny jest termin partnerstwo (partnership). Ten ostatni służy również do nazywania działań kooperacyjnych, podejmowanych w wymiarze terytorialnym. W Wielkiej Brytanii np. terminem tym określa się często tzw. lokalne partnerstwa społeczne, w kontekście rozwiązywania problemów rynku pracy, o czym pisaliśmy na początku niniejszego rozdziału. Jest on szeroko wykorzystywany w Unii Europejskiej, gdzie swoją popularność zawdzięcza szerokiemu angażowaniu się instytucji unijnych w proces promowania partnerskich powiązań czy partnerskiej współpracy. W Polsce pojęcie partnerstwo używane jest w podwójnym znaczeniu. Pierwsze dotyczy partnerstwa społecznego, czyli rozwiązywania problemów społecznych [Zybała 2008]. Drugie jest związane z polityką spójności Unii Europejskiej, gdzie partnerstwo to jedna z podstawowych zasad implementacji polityki spójności. W ujęciu potocznym pojęcie to stosuje się w kontekście wszelkich form współpracy.

W literaturze spotyka się również termin collaborative advantage, który można przetłumaczyć jako korzyści ze współdziałania [Johnes, Ennals 2012]. Nawiązuje do wyniku współdziałania, a nie tylko, jak do tej pory, do procesu współdziałania (przyjmowania wspólnych celów czy partycypacyjnych metod działania). C. Huxhan definiuje korzyści współdziałania jako: „powstanie czegoś szczególnie kreatywnego [...] czego żadna organizacja nie byłaby w stanie sama wytworzyć i kiedy każda organizacja poprzez współdziałanie jest w stanie osiągnąć własne cele lepiej niż działając w pojedynkę" [Huxhan 1993, s. 603]. Zdaniem tego autora wspomniane korzyści związane są z efektem synergii, powstającym w wyniku współdziałania organizacji. Oznacza to, że osiągnięte w wyniku współpracy rezultaty są lepsze niż każdej współpracującej organizacji z osobna.

\subsection{Teorie opisujące współdziałanie międzyorganizacyjne}

Współdziałanie, a szerzej relacje międzyorganizacyjne, mogą być opisywane przez wiele teorii ekonomicznych. Wybór poniższych został podyktowany ich potencjalną przydatnością dla sektora publicznego. Zaprezentujemy więc: teorię zależności od zasobów, teorię wymiany relacyjnej oraz teorię kosztów transakcyjnych. Najbardziej szczegółowo opisano pierwszą z wymienionych teorii, ze względu na jej kluczową rolę w realizacji celów monografii. 


\subsubsection{Teoria zależności od zasobów (resource dependency theory)}

Teoria ta bazuje na przekonaniu, że istnieją współzależności pomiędzy organizacjami, ponieważ indywidualni interesariusze instytucjonalni z danego rynku są właścicielami lub posiadają kontrolę nad istotnymi zasobami (finansowymi, materialnymi, ludzkimi, relacyjnymi czy symbolicznymi). Te z kolei stanowią źródło wywierania wpływu na innych partnerów z otoczenia. Brak dostępu do zasobów może utrudnić indywidualnej organizacji osiągnięcie jej celów strategicznych. Tak więc zależność od zasobów oraz dostęp do nich mogą stanowić znaczną niepewność dla środowiska, w którym działa organizacja. Zgodnie z teorią zależności od zasobów organizacje starają się zmniejszać te zewnętrzne naciski poprzez przejmowanie kontroli nad zasobami potrzebnymi do realizacji celów swoich organizacji. Tradycyjnie dochodzi do tego w procesie rywalizacji. Dostęp do zasobów zapewniają sobie te organizacje, które są skłonne zapłacić najwyższą cenę.

Celem organizacji jest zdobycie kontroli nad zasobami, od których zależy realizacja jej celów strategicznych. Indywidualna organizacja nie ma do nich dostępu lub ma, ale ograniczony. Standardową odpowiedzią na brak dostępu do zasobów jest inwestowanie w coraz bardziej złożone, wewnętrzne struktury, które będą wytwarzać niezbędne zasoby wewnątrz organizacji. W ostatnich latach uznano jednak taką strategię za ryzykowną, głównie ze względu na dynamiczne zmiany w otoczeniu, gdzie organizacje te muszą funkcjonować. W tej sytuacji pozostaje pozyskiwanie zasobów od innych podmiotów, zaś współdziałanie staje się jednym z głównych narzędzi ich pozyskiwania [Donaldson, O’Toole 2002].

Teoria zależności od zasobów pozwala menedżerom lepiej zrozumieć stosunki władzy i zależności między ich organizacją a jej interesariuszami instytucjonalnymi. Posiadana na ten temat wiedza stwarza kierownictwu możliwość identyfikacji ośrodków wywierania wpływu w ich otoczeniu i podsuwa sposoby przynajmniej częściowego zrównoważenia tego wpływu przez tworzenie przeciwwagi [Donaldson, O’Toole 2002]. Według tej teorii wrażliwość organizacji na wpływ jej otoczenia zależy od jej zapotrzebowania na zasoby (finansowe, ludzkie, relacyjne itp.).

Za przyjęciem teorii zależności od zasobów jako teoretycznego odniesienia dla prowadzonych badań w zakresie marketingu terytorialnego $\mathrm{w}$ ujęciu relacyjnym przemawia również fakt, że formułuje się ją na poziomie analizy właściwym dla organizacji (tu: organizacji terytorialnej). Przyjmuje ona punkt widzenia kierownictwa organizacji patrzącego na zewnętrz, a więc w kierunku jej otoczenia. Zwolennikiem wykorzystywania tej teorii w tzw. marketingu strategicznym jest m.in. P. Anderson [2008, s. 243-262], który dostrzega w niej nową perspektywę analizowania ko- 
alicji (wewnętrznych i zewnętrznych) organizacji. J. Pfeffer i G. R. Salancik [1978], uważani za twórców teorii zależności od zasobów, postrzegają organizacje jako koalicje interesów, zmieniające swoje cele i kierunki, gdy w strukturze koalicji zachodzą zmiany. Podobnie jak inni autorzy [Mintzberg 1979], wprowadzają oni rozróżnienie pomiędzy wewnętrznymi a zewnętrznymi koalicjami, chociaż używają innych określeń.

Koalicje wewnętrzne to grupy funkcjonujące wewnątrz organizacji (np. departamenty albo jednostki grupujące pewne funkcje). Do koalicji zewnętrznych zaliczane są zaś takie grupy interesariuszy, jak: akcjonariusze, wierzyciele, dostawcy, władza publiczna, NGO czy inne zainteresowane podmioty. Wspominani badacze kładą główny nacisk na rolę koalicji w otoczeniu organizacji (czyli zewnętrznych), w wywieraniu wpływu na zachowanie organizacji. Uważają oni, że „aby odpowiednio opisać zachowanie organizacji, należy zająć się koalicyjną naturą organizacji oraz sposobem, w jaki organizacje reagują na naciski ze strony otoczenia” [Pfeffer, Salancik 1978, s. 24].

Ograniczenie zależności od zasobów będących w dyspozycji podmiotów zewnętrznych wymaga ustanowienia przeciwwagi dla poszczególnych elementów otoczenia, na których opiera się zależność organizacji. Oznacza to, że pierwszym krokiem do uwzględnienia zależności od zasobów jest dogłębne zrozumienie sieci pod względem znaczenia zasobów dla organizacji oraz określenie zakresu niedoboru. Krokiem drugim będzie znalezienie dróg unikania zależności lub uzależnienie innych uczestników otoczenia od danej organizacji [Hatch 2002]. Organizacje poszukują zatem sposobów pozwalających im opanować zależność od zasobów. W teorii tej kładzie się nacisk na otoczenie, bowiem przetrwanie organizacji zależy ostatecznie od jej zdolności do pozyskania zasobów i od wsparcia otrzymywanego od koalicji zewnętrznych. Również w kontekście procesów globalizacji, zwiększonych przepływów bezpośrednich inwestycji zagranicznych, czy bardziej ogólnie - kapitału finansowego w obrotach międzynarodowych, teoria ta wydaje się właściwą ramą teoretyczną dla kolejnych analiz.

Zdaniem Dowlinga i Pfeffera przetrwanie jest ostatecznym celem organizacji. Dla osiągnięcia tego celu organizacja musi utrzymywać koalicje z różnymi partnerami, skłonnymi do „legitymizacji” jej istnienia [1975, s. 122-136]. Musi więc oferować różne zachęty w zamian za możliwość korzystania z zasobów oraz wsparcia. Wkład ze strony różnych interesariuszy nie jest jednakowo oceniany przez organizację, dlatego koalicje będące nośnikami „zasobów oraz zdolności, które są najbardziej potrzebne lub pożądane przez inną organizację, zdobywają większy wpływ i kontrolę nad tą organizacją".

Dla utrzymania wsparcia zewnętrznych koalicji organizacja musi negocjować warunki wymiany, które zapewnią jej ciągłe dostawy 
niezbędnych zasobów. Jednocześnie organizacja musi pozostać na tyle elastyczna, żeby reagować na sytuacje wynikające ze zmian w otoczeniu. Cele te są często ze sobą sprzeczne, ponieważ pragnienie zapewnienia stabilności i pewności strumieni zasobów często prowadzi do działań ograniczających elastyczność i autonomię. Na przykład integracja w postaci fuzji i przejęć jest jednym ze sposobów radzenia sobie z niepewnością związaną z zależnością od zasobów. Ta metoda stabilizowania wymiany zasobów ogranicza jednak zdolność organizacji do łatwej adaptacji do zmian w otoczeniu.

Pfeffer i Salancik sugerują, że wiele innych działań organizacji można $\mathrm{z}$ jednej strony wytłumaczyć chęcią utrzymania stabilnej wymiany zasobów, z drugiej zaś - potrzebą elastyczności i autonomii. Twierdzą oni, że takie przedsięwzięcia, jak joint venture, wspólna dyrekcja (unia personalna kilku przedsiębiorstw), rozrost organizacji oraz zaangażowanie polityczne mogą być w ten sposób interpretowane. Inne działania, takie jak np. różnicowanie źródeł dostaw, mogą być również interpretowane z perspektywy teorii zależności od zasobów. Teoria ta traktuje więc współdziałanie jako odpowiedź na niepewności związane z dynamicznym otoczeniem. Współdziałanie rozumiane jest tu jako balansowanie pomiędzy utratą autonomii a możliwością uzyskania dostępu do zasobów w wyniku procesu współdziałania. Pogląd ten jest odmienny od teorii wymiany relacyjnej, która koncentruje się na rozwoju wzajemnych relacji na bazie możliwości uzyskania wspólnych korzyści.

\subsubsection{Teoria wymiany relacyjnej (relational exchange theory)}

Organizacje realizujące bardzo złożone zadania mogą rozwijać relacje międzyorganizacyjne w celu rozwiązywania swoich problemów. Organizacja identyfikuje problemy oraz korzyści rozwoju wzajemnych relacji, które mają pomóc w zmierzeniu się z tymi trudnościami. Podstawowe założenia tej teorii są następujące [Donaldson, O’Toole 2002, cyt. za: Fyall, Garrod 2005, s. 147]:

- przyjmuje się, że własny interes organizacji jest podstawowym motywatorem wchodzenia we współdziałanie; organizacje stosują wspólne strategie działań, uwzględniające interesy każdej z nich;

- teoria koncentruje się na relacjach, a nie na transakcjach. Podejście relacyjne ma na celu poznanie struktur relacji, które są tworzone przez organizacje dla wzmocnienia współdziałania. Struktury mają charakter społeczny, zachodzą tu interakcje pomiędzy kluczowym personelem tych organizacji. Ich celem jest osiągnięcie obustronnych korzyści w wymiarze społecznym. 
Korzyści te zostają osiągnięte $\mathrm{w}$ wyniku procesu kontraktowania relacji, z wykorzystaniem dwustronnego mechanizmu koordynowania aktywności wszystkich organizacji zaangażowanych $\mathrm{w}$ ten proces. Powstaje struktura zarządzania oparta raczej na współdziałaniu niż konkurencji. Przynosi to $\mathrm{w}$ rezultacie zacieranie się granic pomiędzy organizacjami, które są połączone z innymi w strukturze sieci. Główne przesłanki warunkujące osiągnięcie wspólnych korzyści to zaufanie i zaangażowanie. Czynniki te zmniejszają wpływ siły organizacji w ramach sieci oraz sprzyjają tworzeniu atmosfery uczciwości w relacjach wymiennych.

\subsubsection{Teoria kosztów transakcyjnych (transaction cost theory)}

Teoria kosztów transakcyjnych wywarła pewien wpływ na zmianę modelu zarządzania w sektorze publicznym [Williamson 2005, s. 69-90]. Pojęcie kosztów transakcyjnych wprowadził do literatury R. Coase. Zauważył, że koordynacja działań gospodarczych nie jest wyłącznie domeną rynku, ale uczestniczą w niej również firmy i inne organizacje. Zaproponował podstawową dla tej teorii tezę, że rynki i firmy stanowią alternatywne sposoby organizacji gospodarczej [Coase 1937]. W sposób ogólny koszty transakcyjne można określić jako koszty społecznej koordynacji czy szerzej - koszty funkcjonowania systemu ekonomicznego. Ze względu jednak na fakt, że głównym problemem społecznej koordynacji jest egzekwowanie i przenoszenie praw własności, terminem koszty transakcyjne określane są wszelkie koszty wynikające z przenoszenia praw własności między partnerami wymiany [Medema 1996, s. 571-578].

Źródłem kosztów transakcyjnych jest zarówno ograniczona racjonalność, utrudniająca wypracowywanie optymalnych rozwiązań, jak i oportunizm partnerów nastawionych na zagarnięcie dla siebie jak największych korzyści. Wysokość tych kosztów zależy od wybranej formy kontraktu, a więc od partnera, z którym wchodzimy w relacje, od staranności przygotowania kontraktu, od dostosowania kontraktu do istniejących warunków itp. Przy organizowaniu transakcji zawieranych między partnerami można przyjąć różne formy kontraktu normującego współpracę. Ekonomicznym celem powyższych wyborów jest minimalizacja kosztów transakcyjnych. Koszty transakcyjne postrzegane są również jako mechanizm zarządzania, przynoszący rentę będącą rezultatem współzależności między ludźmi i między organizacjami [Hennart 2008, s. 339-352].

Zdaniem Williamsona [1993] zasadniczym problemem współdziałania między partnerami jest konieczność dostosowywania się do zmien- 
nych warunków. Konieczność takich zmian może wynikać zarówno ze zmieniającego się otoczenia rynkowego czy zmian o charakterze normatywnym, jak i ze względu na trudne do przewidzenia, a więc niepełne rozeznanie przyszłości przez partnerów. Zmiana warunków współpracy w stosunku do tych określonych w kontrakcie może prowadzić do nieprzewidywalnych reakcji ze strony partnerów. Często skutkuje działaniami o charakterze oportunistycznym.

Koszty transakcyjne to koszty związane wyłącznie z transakcją. Wybór sposobu zarządzania transakcją zależy od jakości instytucji oraz od organizacji, które ułatwiają funkcjonowanie rynku. Przedsiębiorca zawiera kontrakty zewnętrzne z dostawcami, odbiorcami, podwykonawcami, firmami usługowymi itp. Równocześnie zawiera kontrakty wewnątrz przedsiębiorstwa $\mathrm{z}$ różnymi grupami pracowników. Przy wyborze transakcji uwzględniane są takie elementy, jak ograniczona racjonalność oraz oportunizm. Natomiast przy wybieraniu sposobów koordynacji uwzględniane są takie cechy transakcji, jak jej częstotliwość, zakres specyficzności aktywów związanych z transakcją oraz stopień niepewności.

Teoria kosztów transakcyjnych stanowi jak dotychczas bardziej przedmiot dyskusji teoretycznych niż znajduje zastosowanie w praktyce gospodarczej. Jej niewielka popularność wśród praktyków gospodarczych wynika głównie z trudności, na jakie napotyka liczenie tych kosztów. Główna trudność polega bowiem na oddzieleniu kosztów transakcyjnych od kosztów produkcji. W tej sytuacji nie jest możliwe porównywanie kosztów transakcyjnych dla poszczególnych organizacji. Trudności z liczeniem tych kosztów mają również wpływ na ograniczony zakres prowadzonych na ten temat badań empirycznych. Najczęściej przyjmuje się w nich niezbyt precyzyjne założenie, że koszty te są związane z pracownikami wykonującymi tzw. funkcje transakcyjne [Lissowska 2008, s. 41].

Wszystkie trzy omawiane teorie mają związek ze współdziałaniem czy relacjami międzyorganizacyjnymi w sektorze publicznym. Wszystkie również wskazują na ważną rolę relacji partnerskich dla rozwoju poszczególnych organizacji, a więc i rozwoju całego regionu. W świetle powyższej analizy można wyciągnąć wniosek, że najbardziej odpowiednia jako teoretyczne odniesienie do badań w zakresie marketingu terytorialnego w ujęciu relacyjnym jest teoria zależności od zasobów. Jest tu mocno zaakcentowane znaczenie rynku, na którym toczy się rywalizacja o mobilne zasoby między organizacjami. Rywalizacja ta, podobnie jak w sektorze prywatnym, dokonuje się pod wpływem przymusu ekonomicznego, bowiem pozyskanie zasobów lub kontroli nad nimi decyduje o pozycji terytorium na danym rynku. Pozostałe $\mathrm{z}$ omawianych teorii mogą być mniej przydatne do opisu relacji region-interesariusze instytucjonalni, czy to ze względu na nadmierne akcentowanie korzyści ze współdziałania 
dla interesariuszy instytucjonalnych OT, jak to ma miejsce w przypadku teorii wymiany relacyjnej, czy braku możliwości precyzyjnego wyodrębnienia kosztów transakcyjnych, co jest mankamentem stosowania teorii bazujących właśnie na takich kosztach.

\subsection{Typologie współdziałania międzyorganizacyjnego}

\subsubsection{Rodzaje i wymiary relacji partnerskich}

Współdziałanie bądź partnerstwo to pojęcia dość ogólne, z wyraźnym zaznaczeniem kierunku działania. Oba kojarzą się pozytywnie. Wykazują jednak pewne zróżnicowanie, jeśli chodzi o interesy reprezentowane przez poszczególnych partnerów, a te zaś zależą od przestrzeni partnerstwa. Wymiar partnerstwa można ogólnie określić jako nakładanie się trzech sfer - państwa (i sektora publicznego), rynku (obejmującego interesy biznesu) oraz społeczeństwa obywatelskiego (np. organizacje pozarządowe, grupy społeczne). Takie podejście do partnerstwa może pomóc w zidentyfikowaniu kilku klasycznych jego rodzajów, ze względu na podmioty w nich uczestniczące.

Graficzną prezentację tych rodzajów partnerstwa przedstawiono na rys. 3.4. Trójkątna przestrzeń partnerstwa pomiędzy państwem, biznesem i społeczeństwem, którą nazwaliśmy partnerstwem wielosektorowym, jest jedną z głównych cech, odróżniających „nowe” lokalne i regionalne partnerstwa od partnerstw na rzecz współpracy w sektorze publicznym (pomiędzy różnymi szczeblami rządowymi lub pomiędzy różnymi sektorowymi agendami rządowymi). Różni się także od korporacyjnego modelu partnerstwa, w którym te trzy osie stanowily: państwo (rząd), biznes i związki zawodowe. Warto tu zwrócić uwagę na pojawianie się nowych koncepcji partnerstwa korporacyjnego w celu rozwiązywania problemów lokalnego i regionalnego rynku pracy. Obserwujemy więc poszerzanie takiego partnerstwa, polegające na włączaniu do działań organizacji pozarządowych, podmiotów zajmujących się kwestiami zatrudnienia, specjalizujących się np. w szkoleniu pracowników czy świadczeniu usług w zakresie poszukiwania miejsc pracy [Andersen, Mailand 2002].

Prezentowany na rys. 3.4 wymiar partnerstwa pozwala zidentyfikować takie jego rodzaje, jak: partnerstwo wielosektorowe, partnerstwo publiczno-prywatne, partnerstwo publiczno-społeczne oraz partnerstwo prywatno-społeczne. Niżej dokonamy krótkiej ich charakterystyki. 


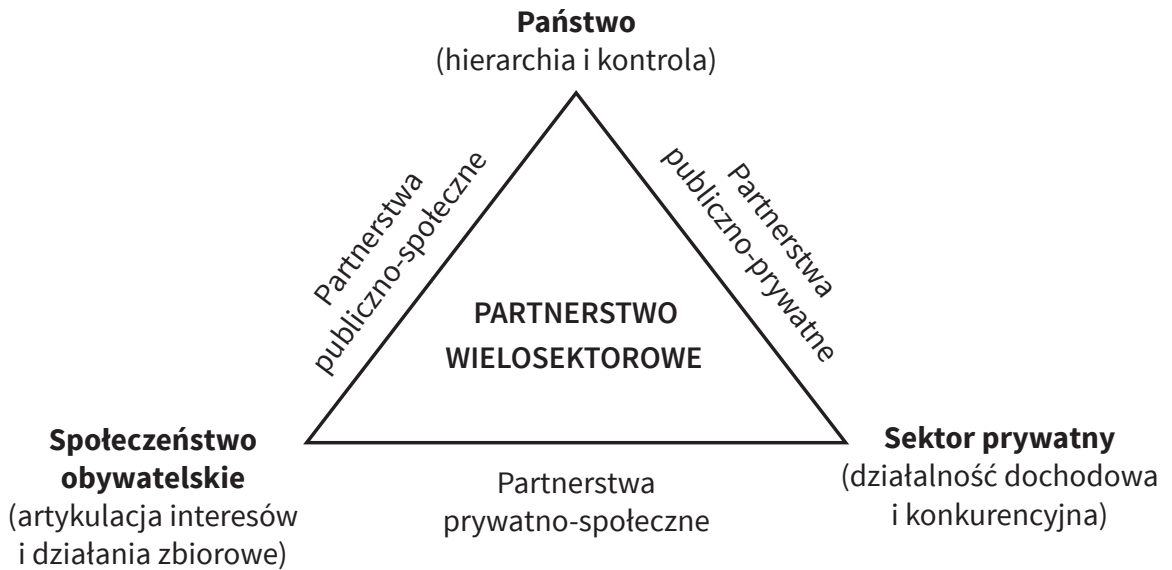

Rys. 3.4. Wymiar przestrzenny relacji partnerskich

Źródło: opracowanie na podstawie [Geddes 2008, s. 213].

Partnerstwo wielosektorowe obejmuje przestrzeń łączącą partnerów ze wszystkich trzech wymienionych wyżej sfer. Istnieje wiele partnerstw tego rodzaju, często posiadających szerokie kompetencje. Są one złożone z wielu partnerów i promowane przez szeroki wachlarz programów UE. Dobrym przykładem tego rodzaju partnerstw w krajach UE jest Wielka Brytania.

Partnerstwo publiczno-prywatne dotyczy relacji podmiotów państwowych lub jednostek samorządu terytorialnego $\mathrm{z}$ jednej strony oraz przedsiębiorstw $\mathrm{z}$ drugiej. Koncentruje się zwykle na kwestiach rozwoju gospodarczego lub rynku pracy.

Partnerstwo publiczno-społeczne obejmuje głównie partnerów publicznych oraz partnerów reprezentujących społeczeństwo obywatelskie. Partnerami wywodzącymi się ze społeczeństwa obywatelskiego są organizacje społeczne bądź grupy, reprezentujące społeczne interesy. Po stronie partnerów publicznych są agendy rządowe i jednostki samorządu terytorialnego.

Partnerstwo prywatno-społeczne występuje głównie pomiędzy przedsiębiorstwami a aktorami będącymi przedstawicielami społeczeństwa obywatelskiego. Jednak partnerstwa takie relatywnie rzadko dotyczą przedsięwzięć zorientowanych na rzecz rozwoju miasta, regionu czy kraju.

Naturę relacji partnerskich można rozpatrywać także w innym kontekście (rys. 3.5). Partnerstwo usytuować można pomiędzy sieciami, czyli luźnymi formami współpracy, oraz formami kontraktowymi, a więc sztywnymi formami współpracy. W takim przypadku relacje partnerskie zawierają elementy każdego z nich, przy czym ich zakres zależy od konkretnej formy, jaką dane partnerstwo przyjmuje. Partnerstwo usytuować można również między 
organizacjami o charakterze hierarchicznym oraz organizacjami w formie dobrowolnych stowarzyszeń. W takim przypadku poszczególne partnerstwa charakteryzują się elementami należącymi do obu tych form. Ich przewaga wynikać może z siły oddziaływania poszczególnych partnerów.

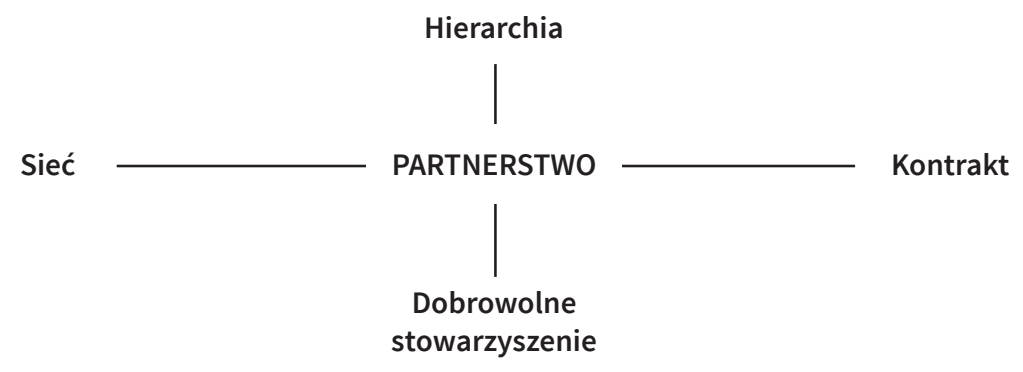

Rys. 3.5. Wymiary relacji partnerskich Źródto: [Geddes 2008, s. 214].

Realizacja strategii partnerstwa $\mathrm{w}$ regionie wymaga znajomości istniejących relacji między samorządem regionu a jego interesariuszami. W dalszej analizie za punkt odniesienia przyjmiemy cały region, z uwzględnieniem obu wymiarów partnerstwa, jakie jego władza (zarząd województwa) i administracja (urząd marszałkowski) prowadzi, realizując politykę rozwoju. $\mathrm{W}$ tab. 3.2 zidentyfikowano podstawowe rodzaje relacji samorządu regionu z jego partnerami.

Analiza tab. 3.2 pozwala zidentyfikować główne tendencje w procesie zarządzania regionem. Pierwsza $z$ nich, najbardziej powszechna, to skłonność do przekazywania kompetencji i zadań na niższe szczeble władzy. Druga to dążenie do partycypacyjnego (partnerskiego) stylu zarządzania. Kolejną tendencję określić można ogólnie jako prywatyzacja zadań publicznych, czyli działania na rzecz powierzania realizacji zadań publicznych podmiotom niepublicznym. Wszystkie one powinny przyczynić się do zwiększonej efektywności w sektorze publicznym, podnoszenia jakości świadczonych usług oraz lepszego zaspokojenia potrzeb mieszkańców.

\subsubsection{Relacje międzyorganizacyjne w warunkach polskich samorządów województw}

W dalszych rozważaniach omówione zostaną zidentyfikowane w tab. 3.2 rodzaje relacji międzyorganizacyjnych $\mathrm{w}$ odniesieniu do samorządów województw. 
Tabela 3.2. Typy powiązań organizacji publicznej z jej interesariuszami instytucjonalnymi

\begin{tabular}{|l|l|l|l|}
\hline \multicolumn{1}{|c|}{$\begin{array}{c}\text { Typ relacji } \\
\text { (sieci) }\end{array}$} & \multicolumn{1}{|c|}{$\begin{array}{c}\text { Przestanki tworzenia } \\
\text { powiązań }\end{array}$} & $\begin{array}{c}\text { Kluczowe trendy } \\
\text { w sektorze } \\
\text { publicznym }\end{array}$ & $\begin{array}{c}\text { Typy więzi } \\
\text { międzysektorowych }\end{array}$ \\
\hline $\begin{array}{l}\text { relacje między } \\
\text { szczeblami } \\
\text { władzy } \\
\text { (wertykalne) }\end{array}$ & $\begin{array}{l}\text { sieci powiązań pomiędzy } \\
\text { szczeblami: } \\
\text { - administracja centralna } \\
\text { - administracja regionalna } \\
\text { - administracja lokalna }\end{array}$ & $\begin{array}{l}\text { dewolucja, partner- } \\
\text { stwo, zarządzanie } \\
\text { wielopoziomowe } \\
\text { (multi-level gover- } \\
\text { nance) }\end{array}$ & publiczno-publiczne \\
\hline $\begin{array}{l}\text { koalicje grup } \\
\text { interesu }\end{array}$ & $\begin{array}{l}\text { tworzone dla identyfiko- } \\
\text { wania problemów publicz- } \\
\text { nych oraz wypracowywa- } \\
\text { nia rozwiązań }\end{array}$ & $\begin{array}{l}\text { dewolucja, partner- } \\
\text { stwo }\end{array}$ & publiczno-publiczne \\
\hline $\begin{array}{l}\text { relacja } \\
\text { legislator- } \\
\text { uczestnik } \\
\text { systemu }\end{array}$ & $\begin{array}{l}\text { wynika z umowy: } \\
\text { samorząd regionu - bene- } \\
\text { ficjenci funduszy publicz- } \\
\text { nych }\end{array}$ & $\begin{array}{l}\text { regulacje, partner- } \\
\text { stwo, prywatyzacja }\end{array}$ & publiczno-prywatne \\
\hline $\begin{array}{l}\text { oparte na } \\
\text { kontraktach }\end{array}$ & $\begin{array}{l}\text { wynika z ustaw dotyczą- } \\
\text { cych partnerstwa publicz- } \\
\text { no-prywatnego }\end{array}$ & $\begin{array}{l}\text { prywatyzacja, part- } \\
\text { nerstwo, dewolucja }\end{array}$ & $\begin{array}{l}\text { publiczno-non- } \\
\text {-profit } \\
\text { publiczno-prywatne } \\
\text { publiczno-publiczne }\end{array}$ \\
\hline $\begin{array}{l}\text { partnerstwo } \\
\text { celu } \\
\text { publicznego }\end{array}$ & $\begin{array}{l}\text { tworzone dla realizacji } \\
\text { wspólnych celów publicz- } \\
\text { nych przez organizacje } \\
\text { pochodzące z różnych } \\
\text { sektorów }\end{array}$ & $\begin{array}{l}\text { prywatyzacja, part- } \\
\text { nerstwo, dewolucja }\end{array}$ & $\begin{array}{l}\text { publiczno-prywat- } \\
\text { ne-non-profit }\end{array}$ \\
\hline
\end{tabular}

Źródło: opracowanie własne z wykorzystaniem [Koliba, Meek, Zia 2011, s. 142].

Relacje między szczeblami władzy. Z perspektywy władz samorządowych będą to z jednej strony relacje „w górę”, czyli z instytucjami centralnymi (np. takimi jak Ministerstwo Rozwoju Regionalnego, Ministerstwo Edukacji, Polska Agencja Informacji i Inwestycji Zagranicznych, Polska Organizacja Turystyczna). Z drugiej zaś będą to relacje samorządu regionu „w dół”, czyli z samorządami lokalnymi (powiaty, gminy). Należy podkreślić, że samorząd regionu, podobnie jak powiatu i gminy, jest autonomiczny i w myśl przepisów nie ma ani nadrzędności, ani podległości wobec innych szczebli władzy ${ }^{4}$. Równocześnie warto przypomnieć, że w kontekście polityki rozwoju, realizowanej na każdym ze wspomnia-

4 Konstytucja Rzeczypospolitej Polskiej, uchwalona w dniu 2 kwietnia 1997 r. przez Zgromadzenie Narodowe, Rozdziat VII. 
nych szczebli władzy, do praktyki zarządzania wprowadzana jest formuła wieloszczeblowego zarządzania (multi-level governance) promowana w ostatnich latach przez instytucje Unii Europejskiej. Popularyzacja zasad współdziałania oraz skuteczne zarządzanie relacjami z samorządami lokalnymi może prowadzić do lepszego wykorzystania zasobów pozostających w gestii tych podmiotów lub zasobów będących pod większym wpływem lokalnych JST na rzecz stymulowania rozwoju regionu. Właśnie jedna $\mathrm{z}$ takich relacji zostanie rozwinięta $\mathrm{w}$ procesie badawczym $\mathrm{w}$ rozdziale szóstym.

Koalicje grup interesu. W przypadku samorządów polskich województw mamy tu do czynienia $\mathrm{z}$ dwoma strukturami współpracy poziomej, takimi jak: Związek Województw RP oraz tzw. Konwent Marszałków. Pierwsza z tych struktur działa jako stowarzyszenie zrzeszające wszystkich marszałków i podejmuje inicjatywy na rzecz szeroko pojętego współdziałania, wymiany doświadczeń i inicjowania wspólnych projektów. Druga natomiast posiada mniej formalny charakter, choć bazowanie w przypadku tej struktury na współtworzeniu jej wartości poprzez zaangażowanie poszczególnych jej członków sprawiło, że jest to poważana struktura na poziomie władzy państwowej. Jest to zatem gremium, które identyfikuje problemy związane z funkcjonowaniem samorządów województw oraz prowadzi dialog na rzecz ich rozwiązywania. Konwent przygotowuje również stanowisko samorządowych władz regionów wobec polityki rządu i innych podmiotów centralnych. Wypracowane zasady funkcjonowania tego gremium i stałe interwały spotkań Marszałków (co 6 miesięcy) sprawiają, że Konwent jest liczącym się, reprezentatywnym partnerem dla władz centralnych.

Relacje: legislator-uczestnik systemu. Tradycyjny układ to relacja pomiędzy pryncypałem i agentem, gdzie pryncypał dysponuje władzą w określonym zakresie i poprzez stosowanie sankcji może oddziaływać na zachowania agentów czy ich kontrolować. Ta hierarchiczna relacja może stawać się relacją dwustronną, gdy podmioty podlegające regulacji mogą uczestniczyć w procesie regulacji, wymieniać poglądy, zabiegać o poprawianie systemu regulacji, współuczestniczyć w procesie tworzenia regulacji oraz kontroli regulacji. Można tutaj nawiązać do polityki rozwoju, która jest nie tylko współrealizowana przez samorząd regionu, lecz także przez niego współkreowana. Jest ona wymiernie wspierana przez fundusze unijne $\mathrm{w}$ ramach polityki spójności UE. Właśnie zasady tej polityki, w tym głównie zasada partnerstwa, sprawia, że nie może być mowy o typowej relacji hierarchicznej np. pomiędzy regionem a beneficjentami instytucjonalnymi.

Tym niemniej ten rodzaj relacji cechuje, przynajmniej w Polsce, swoista zależność beneficjentów od samorządu regionu. Samorządy te stały 
się bowiem w latach 2007-2013 dysponentem znacznych środków europejskich, przeznaczonych na rozwój regionów w procesie realizacji polityki spójności. Usprawnienie wzajemnych relacji przyczynić się może do podniesienia jakości projektów realizowanych na terenie regionu, co powinno zaowocować większymi możliwościami rozwojowymi dla regionu i jego mieszkańców.

Podmioty instytucjonalne regionu z różnych sektorów (publicznego, społecznego i prywatnego) są angażowane $\mathrm{w}$ proces budowy strategii rozwoju województwa, a następnie przy tworzeniu dokumentu doprecyzowującego kierunki wydatkowania środków unijnych - Regionalnego Programu Operacyjnego. Natomiast inni przedstawiciele tych interesariuszy instytucjonalnych - uczestnicy Komitetu Monitorującego RPO - opiniują kryteria wyboru projektów do współfinansowania ze środków unijnych. Zatem uczestnicy systemu najpierw współtworzą regulacje, a następnie ( $\mathrm{z}$ akceptacją i zrozumieniem) poddają się tym regulacjom $\mathrm{i}$ je respektują. Wymaga to od tzw. interesariuszy instytucjonalnych pewnej dojrzałości, stabilności oraz zaufania do władzy samorządowej regionu oraz struktur administracji jej podległych.

Relacje oparte na kontraktach. Tego rodzaju relacje dotyczą tych podmiotów prywatnych lub społecznych, które zdecydują się na długookresową współpracę z samorządami terytorialnymi przy realizacji inwestycji publicznych czy świadczeniu usług. Należy równocześnie podkreślić, że relacje te podlegają przepisom zamówień publicznych, które regulują warunki ramowe oraz strukturyzują kryteria wyboru kontrahentów. Warto zauważyć, że w ostatnich latach polskie regiony wzmocniły instytucjonalną współpracę z sektorem społecznym, tworząc Regionalne Rady Organizacji Pożytku Publicznego, które reprezentują interesy organizacji społecznych z regionu wobec struktur samorządu województwa. Ich działalność oraz wzmocnienie procesu komunikowania z organizacjami pożytku publicznego wpłynęło na usprawnienie systemu powierzania zadań publicznych organizacjom społecznym $w$ regionie. Natomiast relacje z potencjalnymi kontrahentami z rynku przedsiębiorstw są bardziej strukturalizowane poprzez procedury wynikające z zamówień publicznych. Jawność tych procedur jest przejawem otwierania się rynku zamówień publicznych tak szeroko, jak nigdy dotąd.

W warunkach polskich partnerstwo takie dotyczy najczęściej budowy infrastruktury czy podobnych obiektów, które będą dostarczać obywatelom określonych usług. Zasady tzw. partnerstwa publiczno-prywatnego reguluje ustawa z 2008 r. ${ }^{5}$, w której stwierdza się, że jego przedmiotem

5 Ustawa z dnia 19 grudnia 2008 r. o partnerstwie publiczno-prywatnym, Dz.U. z 2009 r. Nr 19, poz. 100 z późn. zm. 
jest wspólna realizacja przedsięwzięć opartych na podziale zadań i ryzyk pomiędzy podmiotem publicznym i partnerem prywatnym. Zapisy ewentualnego kontraktu określają późniejsze zobowiązania obu stron, zatem $\mathrm{w}$ interesie zleceniodawcy, którym jest podmiot publiczny, leży dopilnowanie ich poprawności.

Partnerstwo celu publicznego. Dotyczy współdziałania z organizacjami prywatnymi i społecznymi przy realizacji celów o charakterze publicznym. Współdziałanie takie polega na podziale zadań między tymi organizacjami oraz wykorzystywaniu ich wiedzy i umiejętności dla zrealizowania wspólnych przedsięwzięć w sposób efektywny i korzystny dla społeczeństwa.

Jako przykład tego typu relacji warto podać regionalny system innowacji (RSI), którego liderem może być zarówno władza regionu, jak i któryś z uczestniczących w systemie podmiotów. Tworzenie sprawnych systemów współdziałania w regionie przyniesie zwiększone zaangażowanie zasobów interesariuszy samorządu regionu, co powinno zaowocować podnoszeniem jego konkurencyjności. Współdziałanie takie może skutkować pojawieniem się efektów synergii, np. w obszarze generowania innowacji i ich wdrażania $\mathrm{w}$ regionie. $\mathrm{W}$ ramach szeroko rozumianych partnerstw publiczno-prywatnych samorząd regionu angażuje się $\mathrm{w}$ takie przedsięwzięcia, jak: parki naukowo-technologiczne, wspólne programy marketingowe czy promocyjne, współpracę międzynarodową w ramach regionów partnerskich itp.

\subsection{Podsumowanie}

Relacje partnerskie organizacji publicznej z jej otoczeniem są kształtowane w różny sposób w poszczególnych krajach, a na ich kształt ma wpływ polityka publiczna zarówno na szczeblu krajowym, jak i europejskim. Są one znacznie bardziej zaawansowane w krajach rozwiniętych, gdzie proces ich rozwoju dokonuje się od kilkudziesięciu lat, w porównaniu np. z krajami postkomunistycznymi. Te ostatnie nadrabiają dopiero zaległości i podejmują próby budowy relacji partnerskich na możliwie wielu polach funkcjonowania organizacji publicznych. Duży wpływ na budowę tych relacji od pewnego czasu wywiera Unia Europejska, dostarczająca zasoby, o które toczy się rywalizacja różnych podmiotów.

Dla określenia relacji międzyorganizacyjnych w literaturze wykorzystuje się wiele terminów, takich jak: współpraca, współdziałanie, partnerstwo, koordynacja, sieci. Podjęta w rozdziale analiza bibliometryczna pokazuje, że autorzy artykułów naukowych z zakresu działalności sektora publicznego coraz częściej podejmują problematykę relacji, zaś termin 
„Współdziałanie” posiada najwyższe przyrosty częstotliwości pojawiania się wśród słów kluczowych artykułów naukowych. W dyskursie naukowym problematyka relacji międzyorganizacyjnych jest opierana na różnych teoriach, z których autor zdecydował się wyróżnić teorię zależności od zasobów, stanowiącą podstawę rozważań prowadzonych w rozdziale szóstym w odniesieniu do sektora publicznego.

Organizacje publiczne wchodzą w różnorodne związki z otaczającymi je interesariuszami instytucjonalnymi. Przykładowo organizacja terytorialna wchodzi w interakcje z podobnymi organizacjami na różnych szczeblach władzy, integruje się z podobnymi sobie przy identyfikowaniu wspólnych problemów i szukaniu ich rozwiązań. Organizacje terytorialne prowadzące politykę publiczną (regionalną/lokalną) wchodzą w relacje z jej beneficjentami, zaś z wybranymi podmiotami prywatnymi i społecznymi wchodzą $\mathrm{w}$ relacje oparte na kontraktach. Wreszcie organizacje publiczne inicjują lub przystępują do partnerstw terytorialnych, które zwykle mają charakter międzysektorowy i dotyczą problemów wspólnych dla rozwoju terytorium. 


\section{Rozdział 4 \\ Metodyka badań empirycznych}

Opis metodyki badań empirycznych zaprezentowanych w kolejnych rozdziałach poprzedzimy uzasadnieniem wyboru światopoglądu, do którego zdecydowano się odwoływać. Chodzi o światopogląd rozumiany przez Creswella [2013, s. 31] jako: „ogólne spojrzenie badacza na świat i naturę badań naukowych", nazywany też ontologią [Crotty 1998] czy szerzej: metodologią badań naukowych [Neuman 2000]. Spośród czterech światopoglądów, do których badacze najczęściej się odwołują (takich jak postpozytywizm [Phillips, Burbules 2000], konstruktywizm [Neuman 2000], aktywizm [Heron, Reason 1997, s. 274-294], pragmatyzm [Cherryholmes 1992, s. 13-17]), autor zdecydował się przyjąć ten ostatni. Światopogląd pragmatyczny nie jest związany z żadnym konkretnym systemem filozofii i rzeczywistości, a znajduje zastosowanie w badaniach mieszanych. Wykorzystuje się tam dość liberalnie założenia zarówno ilościowe, jak i jakościowe. Badacze posiadają swobodę dobierania takich metod i technik, które prowadzą do poznania prawdy oraz odpowiadają ich potrzebom i celom. Równoczesne pozyskiwanie danych ilościowych i jakościowych jest akceptowalne i zasadne, bowiem pozwala lepiej wyjaśnić problem. Według przedstawicieli tego światopoglądu badania naukowe odbywają się w kontekstach prawnych i administracyjnych, politycznych, historycznych i in. [Creswell 2013, s. 36-37].

W opisywanych niżej badaniach przyjęto światopogląd pragmatyczny jako filozoficzną podbudowę badań mieszanych [Morgan 2007, s. 48-76]. Pozwala on bowiem na oparcie badań na różnorodności metod czy zróżnicowaniu założeń, a także na gromadzeniu i analizowaniu danych $\mathrm{w}$ różny sposób. Wykorzystywana $\mathrm{w}$ badaniach metoda studium przypadku dobrze wpisuje się w ten światopogląd, zaś wykorzystywane $\mathrm{w}$ jej ramach techniki badawcze umożliwiają pełniejsze poznanie rzeczywistości. W pracy przyjęto mieszaną strategię badawczą charakteryzującą się sekwencyjnością. Najpierw przeprowadzono badanie eksploracyjne, aby następnie, bazując na uzyskanych wynikach, podjąć decyzję o zawężeniu 
obszaru badania i skoncentrowaniu się na wybranych relacjach, przypadkach oraz jednostkach badawczych.

W ramach tzw. metod mieszanych stosuje się zarówno wcześniej zaplanowane techniki, jak i te, które wydadzą się adekwatne do podjętego problemu już w trakcie badania. Zadawane są pytania otwarte i zamknięte. Wykorzystuje się różne rodzaje danych o charakterze ilościowym i jakościowym, ze wszystkich dostępnych źródeł. Stosuje się także statystyczne techniki analizy oraz techniki jakościowe. Wnioskowania dokonuje się na podstawie wyników pochodzących z różnych rodzajów danych. Wybór tej metody badań był podyktowany specyfiką problemu badawczego, dotychczasowym doświadczeniem i zainteresowaniami autora oraz tym, że w naukach o zarządzaniu coraz częściej wykorzystuje się obok badań ilościowych również jakościowe w rozmaitych konfiguracjach i proporcjach.

Rozdział ten w całości poświęcono metodyce badań empirycznych, które były realizowane przez autora w latach 2009-2014. Poświęcenie odrębnego rozdziału metodyce badań było konieczne zarówno ze względu na uzasadnienie wyboru metody prowadzonych badań (zbiorowe studium przypadku), jak i opis zastosowanej w ramach tej metody triangulacji danych, co pozwoliło na pełniejsze poznanie opisywanych zjawisk i ułatwiło późniejsze wnioskowanie.

Prezentacja rezultatów badań empirycznych składa się z dwóch następujących po sobie części. Pierwsza (rozdział piąty) stanowi eksplorację relacji międzyorganizacyjnych samorządowego regionu w procesie realizacji polityki rozwoju, natomiast druga (rozdział szósty) jest próbą opisu jednej z relacji (region-miasto) z perspektywy teorii zależności od zasobów. Obie części badań przeprowadzono z uwzględnieniem perspektywy organizacyjnej, gdzie samorządowy region traktowano jako organizację terytorialną, czyli urząd marszałkowski z jego kierownictwem. Badania zostały wykonane w kontekście prowadzonych działań na rzecz rozwoju gospodarczego, z podkreśleniem marketingowych procesów przyciągania do regionu czynników rozwoju, których nośnikami są inwestorzy, turyści i studenci.

Niniejszy rozdział rozpoczyna omówienie przesłanek prowadzonych badań oraz założeń badawczych. Następnie przedstawiono definicje operacyjne pojęć wykorzystywanych przy omawianiu rezultatów badań. Ze względu na fakt, że w obu etapach badań empirycznych zastosowano metodę zbiorowego studium przypadku, w odrębnej części rozdziału dokonano uzasadnienia tego wyboru. Zasadniczą część rozdziału stanowi prezentacja trzech etapów badań, z których pierwszy to studia literaturowe i analiza bibliometryczna, natomiast dwa kolejne to eksploracja relacji regionu samorządowego oraz opis zjawiska współpracy regionu z miastem w procesach marketingowych z perspektywy organizacyjnej. 


\subsection{Przesłanki prowadzonych badań i założenia badawcze}

Marketing terytorialny bazujący na klasycznym, transakcyjnym podejściu, w zestawieniu z rozwojem modelu Public Governance w sektorze publicznym, wydaje się mieć obecnie ograniczone zastosowanie. Dzieje się tak ze względu na jego złożoność, przejawiającą się m.in. w wielości uczestników różnych procesów oraz dynamicznie zmieniające się warunki otoczenia organizacji terytorialnych. Skłania to do podejmowania prób wypracowywania nowych koncepcji marketingu terytorialnego, bazujących na podstawach teoretycznych, nawiązujących do relacji międzyorganizacyjnych. Współczesne przemiany w sposobie prowadzenia polityki publicznej, uwzględniające koncepcję współrządzenia poprzez interakcje organizacyjne oraz udane zmiany paradygmatu marketingu w sektorze przedsiębiorstw, pozwalającego efektywniej zarządzać relacjami z interesariuszami (marketing relacji, marketing interesariuszy), uzasadniają podejmowanie działań na rzecz rozwoju nowych koncepcji marketingowych, adekwatnych do specyfiki organizacji publicznych oraz wspomnianych uwarunkowań.

Jednym ze sposobów usprawniania administracji publicznej jest kreowanie sytuacji konkurencyjnej, czyli rynku. W badaniach przyjęto założenie, że o sytuacji rynkowej, w kontekście działań samorządów terytorialnych, można mówić w obszarze przyciągania inwestorów, turystów oraz pozyskiwania do terytorium potencjalnych studentów. Dopiero taka konkurencyjna sytuacja, gdzie mobilni, zewnętrzni użytkownicy terytorium mogą realnie wybrać inną ofertę, kreuje przestrzeń do wykorzystania koncepcji marketingu, czego skutkiem może być podniesienie wartości oferty terytorialnej dla jej użytkowników.

Podjęte przez autora badania można potraktować jako wyjście naprzeciw oczekiwaniom zawartym w książce pod redakcją S. Osborne’a, w której autorzy rozdziału pt.: Relationship marketing, relational capital and the governance... formułują następujący postulat: „obecnie ważnym zadaniem jest opracowanie modelu zarządzania relacjami, który byłby mocniej osadzony w obszarach administracji publicznej i zarządzania i który pozwala uwzględnić koncepcje marketingu relacji i kapitału relacyjnego" [2010, s. 195]. Faktycznie, należy się zgodzić, że istniała luka badawcza w tym wąskim obszarze, choć sama problematyka sieci powiązań kooperacyjnych czy współpracy międzyorganizacyjnej, jak wykazują prezentowane wcześniej wyniki badań bibliometrycznych, staje się coraz bardziej popularna wśród badaczy, zarówno w obszarze zarządzania w sektorze przedsiębiorstw, jak i w sektorze publicznym. 
Badania wpisują się w proces poszukiwania właściwej perspektywy teoretycznej do opisu działań marketingowych podejmowanych przez organizację terytorialną na szczeblu regionu, zorientowanych na przyciąganie do regionu mobilnych czynników wzrostu. Za wyborem organizacji terytorialnej na szczeblu regionu do badań przemawia fakt, że na tym poziomie samorządu terytorialnego usytuowano kompetencje w zakresie kreowania polityki rozwoju gospodarczego. Należy przyjąć, że to, co w sektorze publicznym nosi nazwę polityki publicznej, w sektorze prywatnym określane jest jako zarządzanie strategiczne.

W badaniach będziemy się odnosić do teorii interesariuszy, jednej z bazowych teorii zarządzania strategicznego przedsiębiorstw. Jej wykorzystanie w odniesieniu do organizacji publicznej - organizacji terytorialnej, uzasadnia przyjęcie przez autora założenia, że region w zakresie pozyskiwania mobilnych czynników wzrostu jest metaforą przedsiębiorstwa. Chodzi tu o te zadania i kompetencje samorządowego regionu, które dotyczą działań rynkowych, gdzie potencjalni rywale (inne regiony) starają się również przyciągnąć do siebie mobilne zasoby, będące w dyspozycji inwestorów, turystów i studentów. Celem takich działan jest maksymalizacja wartości dla potencjalnych użytkowników regionu, którzy są mobilnymi nośnikami kapitału finansowego i intelektualnego. Natomiast mieszkańców regionu należy tu traktować jak udziałowców terytorium, którzy w przypadku udanych działań skutkujących napływem czynników wzrostu, będą odczuwać korzyści w postaci takich wartości, jak: możliwości zatrudnienia (efekt pozyskania inwestorów, turystów), stworzenie dynamicznej, kreatywnej atmosfery w mieście (efekt pozyskania studentów) itp.

Warto zauważyć, że organizacja terytorialna jest niejednolita jeżeli chodzi o model stosowanego zarządzania publicznego. Jak zaznaczono w rozdziale pierwszym, w ostatnich dekadach zarówno w Europie, jak i na innych kontynentach, obserwujemy proces ewolucji modelu zarządzania publicznego. Dokonuje się on od modelu biurokratycznego, charakteryzującego się racjonalną rutyną, do modelu współrządzenia (governance), którego podstawą są relacje $\mathrm{z}$ otoczeniem instytucjonalnym. Ten ostatni model bardziej odpowiada współczesnym warunkom otoczenia. Należy jednak zgodzić się z Osbornem [2010], że określony model jedynie dominuje w organizacji, a równolegle występują elementy charakterystyczne dla pozostałych modeli.

Podjęta przez autora problematyka jest bardzo złożona, co wymaga przyjęcia szeregu założeń, aby uwaga badacza mogła być skupiona na wybranych elementach badanej rzeczywistości. W tym kontekście sformułowano następujące założenia badawcze:

- organizacja terytorialna jest w wymiarze marketingowym metaforą przedsiębiorstwa; 
- złożoność organizacji terytorialnej w zakresie wielości jej celów, zadań i obowiązków sprawia, że modele zarządcze, które przyjmują ich kierownictwa mają charakter złożony i obok dominującego modelu (np. biurokratyczny, NPM lub Public Governance) występują też elementy pozostałych modeli zarządzania publicznego;

- decydujący wpływ na poziom współdziałania organizacji terytorialnej z jej interesariuszami instytucjonalnymi mają postawy i działania menedżerów publicznych - dyrektorów departamentów w urzędach marszałkowskich. Dyrektorzy ci mają bowiem największe możliwości w zakresie inicjowania i prowadzenia bliskiej współpracy międzyorganizacyjnej;

- współpraca międzyorganizacyjna to nabierający znaczenia instrument zarządzania publicznego, odpowiadający modelowi zarządzania publicznego typu współrządzenie (Public Governance);

- dobór menedżerów publicznych do kierowania poszczególnymi jednostkami organizacyjnymi OT (departamentami w badanych urzędach marszałkowskich) miał charakter merytoryczny, a ich kwalifikacje i postawy są adekwatne do specyfiki zadań powierzonych tym jednostkom;

- badani menedżerowie posiadają pełną wiedzę o relacjach reprezentowanych przez nich organizacji, a ich postawy utożsamiane są z postawami tych jednostek;

- przyjęto, że kontekst prowadzonych badań - polityka rozwoju gospodarczego na szczeblu regionu - jest zgodny z koncepcją regionu uczącego się (learning region).

\subsection{Operacjonalizacja pojęć}

W monografii przyjęto poniższe definicje operacyjne.

Marketing terytorialny to proces zarządczy zorientowany na maksymalizację wartości dla udziałowców terytorium (mieszkańców) poprzez działanie na rzecz pozyskiwania nowych zasobów rozwojowych, których nośnikami są takie mobilne podmioty, jak: inwestorzy, turyści, potencjalni studenci, potencjalni nowi mieszkańcy, odwiedzający jednodniowi itp. Na maksymalizację wartości dla udziałowców terytorium (mieszkańców) pozytywnie wpływa efektywna współpraca regionu (tu: organizacji terytorialnej) $\mathrm{z}$ interesariuszami instytucjonalnymi.

Organizacja terytorialna (OT) to struktury organizacyjne samorządu terytorialnego (tu: urząd marszałkowski) wraz z ich kierownictwem 
(tu: marszałek województwa) reprezentujące interesy wspólnoty terytorialnej (mieszkańców regionu) określonej granicami podziału administracyjnego (tu: obszar województwa). Mieszkańcy traktowani są równocześnie jako swoiści udziałowcy terytorium, posiadający bezpośredni wpływ na rządzenie poprzez demokratyczne instytucje państwa (tu: samorząd województwa) i instrumenty governance, zwiększające rolę mieszkańców województwa w wytyczaniu kierunków rozwoju i współuczestniczeniu $w$ tych procesach. Organizacja terytorialna w przyjętym rozumieniu nie obejmuje jej interesariuszy instytucjonalnych, funkcjonujących na terytorium województwa (uczelni wyższych, organizacji samorządu gospodarczego, NGO, lokalnych JST itp.). Interesariusze ci są jednak potencjalnymi i pożądanymi partnerami OT na szczeblu regionu.

Departamenty rynkowe (RYN). W badaniu przyjęto, że RYN to te jednostki organizacyjne administracji samorządowej (tu: urzędu marszałkowskiego), które w zakresie powierzonych im zadań mają wchodzić $\mathrm{w}$ relacje zewnętrzne z podmiotami publicznymi i niepublicznymi, przy czym relacje te nie są oparte na zależności instytucjonalnej (nadrzędność, podległość), ale mają charakter dobrowolny. W kontekście prowadzonej przez samorząd województwa polityki rozwoju będą to te jednostki, które w sposób bezpośredni podejmują działania na rzecz budowania zewnętrznej atrakcyjności terytorium, poprzez przyciąganie zewnętrznych czynników wzrostu, takich jak: kapitał finansowy (inwestorzy, turyści, odwiedzający jednodniowi) oraz kapitał intelektualny (nowi wykształceni mieszkańcy, potencjalni studenci, uczniowie), a także te podmioty, które podejmują działania na rzecz zwiększania innowacyjności regionu. W tej grupie znalazły się również jednostki OT, które koordynują działania związane $\mathrm{z}$ budowaniem zewnętrznego wizerunku województwa, przez co usprawniają relacje ze środowiskiem zewnętrznym. Wspólną cechą jednostek organizacyjnych zakwalifikowanych jako "rynkowe” jest to, że dla podnoszenia skuteczności swych działań muszą wchodzić $\mathrm{w}$ zewnętrzne relacje z podmiotami publicznymi i niepublicznymi oraz starać się mobilizować je do działań mających z jednej strony realizować cel marketingowy regionu (budowanie zewnętrznej konkurencyjności), a z drugiej - przynosić wymierne korzyści wspomnianym interesariuszom instytucjonalnym. Ich relacje ze środowiskiem zewnętrznym dobrze opisuje model Public Governance, którego wyróżnikiem jest współdziałanie.

Departamenty sektorowe (SEK). W badaniu tak nazwano jednostki organizacyjne OT (urzędów marszałkowskich), które odpowiadają za realizację zadań w określonych obszarach merytorycznych, w których samorząd województwa realizuje zadania publiczne, takich jak: kultura, edukacja, sport, ochrona środowiska itp. W nomenklaturze administracji 
samorządowej to tzw. zadania własne samorządu województwa. Ich realizacja prowadzi do zaspakajania potrzeb regionalnej wspólnoty z dochodów własnych i na własną odpowiedzialność.

Zadania tych departamentów, zwłaszcza sposoby ich działalności, są regulowane bardziej precyzyjnie, wskazane są także konkretne podmioty, z którymi mają współpracować. Zadania te i sposoby ich realizacji opisane są w odrębnych aktach normatywnych. Relacje tych podmiotów z organizacjami zewnętrznymi są obowiązkowe i podlegają regulacjom prawnym. $\mathrm{W}$ żargonie typowym dla zarządzania publicznego departamenty sektorowe nazywane są niekiedy departamentami merytorycznymi. Relacje ze środowiskiem zewnętrznym tych jednostek opisuje model NPM.

Departamenty administracyjne (ADM). Są to jednostki organizacyjne OT (tu: w urzędach marszałkowskich), które pełnią funkcje wewnętrzne i stanowią wsparcie administracyjne dla pozostałych jednostek organizacyjnych urzędu marszałkowskiego. Są to funkcje związane z finansami, organizacją administracyjną urzędu, obsługą kancelaryjną, informatyzacją urzędu itp. Ten rodzaj jednostek organizacyjnych jest w wysokim stopniu zbiurokratyzowany. W żargonie urzędowym departamenty administracyjne nazywane są niekiedy obsługowymi bądź technicznymi.

Do tej kategorii zaliczono również jednostki, które uczestniczą w procesie dystrybucji funduszy unijnych, chociaż większość ich klientów to beneficjenci zewnętrzni. Za takim zaszeregowaniem tych jednostek przemawia wysoki stopień formalizacji stosowanych procedur. Są to procedury biurokratyczne, mające służyć podnoszeniu jakości usług świadczonych $w$ tym zakresie oraz zapobiegać korupcji. Ich relacje ze środowiskiem zewnętrznym opisuje model biurokratyczny.

Orientacja relacyjna OT to realizacja celów w zakresie maksymalizacji wartości dla użytkowników zewnętrznych i udziałowców terytorium (jego mieszkańców) we współdziałaniu $z$ interesariuszami instytucjonalnymi, z uwzględnieniem głosu udziałowców na poszczególnych etapach procesów marketingowych, zorientowanych na pozyskiwanie inwestorów, turystów i studentów. Relacje z interesariuszami instytucjonalnymi i umiejętność współpracy z nimi są tu zasobem niematerialnym, mającym wpływ na przewagę relacyjną terytorium.

Orientacja rynkowa/marketingowa OT to generowanie przez region wiedzy na temat jego zewnętrznych użytkowników. Jest to wiedza dotycząca zarówno grup docelowych (o inwestorach, turystach, studentach), jak i wiedza o konkurentach. Orientacja ta to również upowszechnianie pozyskanych w ten sposób informacji wewnątrz organizacji, jak i ich udostępnianie na potrzeby potencjalnych oraz aktualnych użytkowników (responsywność). Wraz z rozwojem integrującej funkcji marketingu 
w organizacjach terminy - orientacja marketingowa $(\mathrm{OM})$ i orientacja rynkowa (OR) - można traktować jak tożsame.

Menedżer publiczny to dyrektor departamentu, wydziału lub innej podstawowej jednostki organizacyjnej urzędu administracji publicznej (samorządowej lub państwowej), posiadający relatywnie dużą samodzielność w doborze środków realizacji zadań powierzonych jednostce oraz w doborze jej pracowników.

Polityka rozwoju to zespół wzajemnie powiązanych działań, podejmowanych i realizowanych w celu: zapewnienia trwałego i zrównoważonego rozwoju terytorium, spójności społeczno-gospodarczej i terytorialnej, podnoszenia konkurencyjności gospodarki oraz tworzenia nowych miejsc pracy w skali krajowej, regionalnej lub lokalnej. Podnoszenie konkurencyjności terytorium rozumiane jest tu jako jego zdolność do przyciągania mobilnych czynników wzrostu (kapitału finansowego, kapitału intelektualnego) do terytorium.

Ze względu na fakt, iż rozwój terytorium dotyczy bardzo szerokiego wachlarza działań podejmowanych w różnych obszarach, w badaniu skoncentrowano się na tych zadaniach samorządu województwa, które w świetle polityki spójności UE wydają się najważniejsze dla konkurencyjności regionów, a więc na: rozwoju zasobów ludzkich, rozwoju nauki i podnoszeniu innowacyjności gospodarki, wspieraniu rozwoju przedsiębiorczości, tworzeniu i modernizacji infrastruktury społecznej i technicznej, rozwoju kultury i turystyki oraz budowaniu silnej marki regionu. Są to równocześnie obszary, które tworzą wartość terytorium dla potencjalnych grup jego zewnętrznych użytkowników, takich jak: inwestorzy, turyści, studenci.

Użytkownik regionu/miasta to wewnętrzny lub zewnętrzny klient, którego potrzeby mogą być zaspokojone na danym terytorium poprzez kreowane wartości przez sektor publiczny, prywatny i społeczny. Za kryterium podziału użytkowników przyjęto ich mobilność. Użytkownicy wewnętrzni to stali rezydenci regionu, o relatywnie mniejszej mobilności. Natomiast użytkownicy zewnętrzni to osoby i podmioty, które stają się użytkownikami terytorium wraz z ich czasowym przyjazdem lub długookresową delokalizacją do terytorium. Użytkownicy zewnętrzni stanowią wartość dla użytkowników wewnętrznych (mieszkańców). Są oni bowiem dostarczycielami mobilnych czynników wzrostu, czyli zasobów w postaci środków finansowych, kapitału ludzkiego, kapitału intelektualnego.

Współpracę międzyorganizacyjną będziemy rozumieć jako współpracę podmiotów sektora publicznego (tu: urzędu marszałkowskiego) z podmiotami sektorów: publicznego (administracja państwowa, administracja samorządowa) oraz niepublicznego (prywatnego i społecznego). 
Interesariusze instytucjonalni regionu to organizacje publiczne i niepubliczne, których obszary działania i wytyczone cele w odniesieniu do poszczególnych grup użytkowników terytorium pokrywają się z obszarami działania i celami organizacji terytorialnej.

Według ustawy o samorządzie województwa interesariusze instytucjonalni to: samorządy lokalne (gminy i powiaty) i ich związki, wojewoda i jego służby, uczelnie wyższe i ośrodki naukowo-badawcze, samorządy innych województw w Polsce, organizacje samorządu gospodarczego i zawodowego, organizacje pozarządowe oraz inne podmioty, których wielkość bądź skala oddziaływania uzasadnia bezpośrednie relacje z samorządem województwa (np. duzi inwestorzy).

Interesariuszy instytucjonalnych OT na szczeblu regionu podzielono na publicznych i niepublicznych, zaś w tej drugiej kategorii wyróżniono prywatnych i społecznych. Wśród partnerów publicznych wyróżniono następujące kategorie: lokalne JST z obszaru województwa, związki JST, wojewoda i jego służby, centralna administracja rządowa, publiczne szkoły wyższe. Natomiast do organizacji niepublicznych zaliczono: organizacje samorządu gospodarczego, samorząd zawodowy, organizacje pozarządowe, prywatne szkoły wyższe, indywidualne przedsiębiorstwa, prywatne ośrodki $B+R$.

W przypadku interesariuszy w postaci organizacji publicznych w badaniu skoncentrowano się na trzech kluczowych kategoriach, które niżej zostaną krótko scharakteryzowane.

1) Lokalne jednostki samorządu terytorialnego. $W$ tej grupie znalazły się miasta, gminy, powiaty i ich związki leżące na obszarze, który jest objęty zasięgiem badanej organizacji terytorialnej. Relacje lokalnych JST z samorządem województwa są pozbawione zwierzchności. Są to formalnie niezależne podmioty, choć funkcjonalnie ze sobą powiązane. $\mathrm{Z}$ samorządem regionu łączy je szereg podobieństw - m.in. te same przepisy finansowe, podległość tym samym instytucjom kontrolnym czy przepisy dotyczące pracowników samorządowych. Z tego względu można przyjąć, że zbliżają one do siebie sektor samorządowy na wszystkich jego szczeblach (województwo, powiat, gmina).

2) Administracja państwowa. $W$ tej grupie znaleźli się respondenci z urzędów wojewódzkich, które wobec samorządów terytorialnych pełnią głównie funkcje kontrolne. Zdecydowano się włączyć do tej grupy również respondentów z tych ministerstw i agencji rządowych, które $\mathrm{w}$ bezpośredni sposób uczestniczą $\mathrm{w}$ prowadzeniu polityki rozwoju. W wymiarze formalno-prawnym administracja ta sprawuje nadzór i kontrolę nad działalnością JST. Dodatkowo, w kontekście prowadzonej polityki spójności na 
szczeblu regionu, administracja wojewódzka prowadzi rozliczenia finansowe funduszy europejskich oraz kontroluje ich wydatkowanie. $Z$ tej perspektywy trudno uznać administrację państwową za równorzędnego partnera do współpracy, ale raczej za partnera obowiązkowego, gdzie w relacjach dominuje wymiar formalny.

3) Uczelnie wyższe. To podmioty publiczne, które są podległe Ministerstwu Nauki i Szkolnictwa Wyższego. Relacje pomiędzy samorządem województwa a uczelniami działającymi na jego terenie nie są ograniczone przepisami i przez to posiadają potencjał, który stanowi szansę na zbudowanie silnej pozycji konkurencyjnej wobec innych ośrodków, ale też może stanowić słabość i czynnik negatywnie oddziałujący na rozwój.

\subsection{Uzasadnienie wyboru wielokrotnego studium przypadku jako metody badań}

Prezentację poszczególnych etapów badań poprzedzono bardziej ogólną refleksją metodologiczną, odnoszącą się do specyfiki podejmowanych problemów oraz liczebności jednostek badawczych. Niżej przedstawiono szereg argumentów przemawiających za podjętymi decyzjami. Badanie zostało oparte na metodzie wielokrotnego studium przypadku (multi case study method) [Yin 2009, s. 25-66], a nazywanej przez R. Stake'a [2000] „zbiorowym studium przypadku”. Warto na początku uzasadnić wybór tej metody do badań relacji zewnętrznych organizacji terytorialnej na szczeblu regionu, w kontekście realizowania procesów marketingowych. Pierwszym przemawiającym za tym argumentem jest liczba badanych podmiotów. W przypadku sektora przedsiębiorstw mamy do czynienia z setkami, tysiącami czy setkami tysięcy podmiotów gospodarczych, które działają na rynku. Przy takiej ich liczbie nietrudno dokonać wyboru reprezentatywnej próby ze zbiorowości generalnej, by na niej prowadzić obserwacje, których wnioski będą następnie uogólniane na całość populacji generalnej.

W przypadku sektora publicznego mamy do czynienia z dużo mniejszą liczbą podmiotów, choć przeciętnie będą to podmioty większe niż działające w sektorze przedsiębiorstw, gdzie 99\% należy do tzw. sektora MSP. W skali kraju w niektórych „segmentach” sektora publicznego mamy kilka tysięcy podmiotów, tak jak w przypadku gmin czy spółek komunalnych. W innych przypadkach - kilkaset podmiotów, tak jak w przypadku publicznych uczelni wyższych czy powiatów. W takich sytuacjach bada- 
cze podejmujący problemy zarządzania w sektorze publicznym starają się pozyskać próby powyżej 100 jednostek, aby móc skorzystać choćby z uproszczonych technik analizy statystycznej i argumentować zasadność ekstrapolowania uzyskanych w ten sposób wyników na całą zbiorowość. Może to budzić wątpliwości metodologiczne, a nieznajomość zmiennego kontekstu badanych zjawisk sprawia, że uzyskane w ten sposób wyniki stają się dyskusyjne.

Problemy związane z minimalną liczebnością badanych prób stają się szczególnie ważkie w przypadku struktur administracyjnych polskich regionów na poziomie NUTS 2, których w 1998 r. utworzono szesnaście. Takie podmioty, jak urzędy wojewódzkie, urzędy marszałkowskie czy inne struktury organizacyjne dedykowane polskim województwom posiadają niewystarczającą liczebność, aby stosować statystyczne techniki analizy zebranych w nich danych. Równocześnie, ze względu na ich rolę np. w procesie realizacji polityki publicznej, nie należy analizować ich łącznie z innymi podmiotami, pełniącymi inne funkcje, inaczej usytuowanymi w systemie administracyjnym kraju czy województwa.

W Polsce mamy zaledwie szesnaście województw, a w każdym z urzędów marszałkowskich od kilku do kilkunastu jednostek organizacyjnych, z których składa się samorządowa administracja. Jeżeli nawet przyjmiemy, że jednostką analityczną będzie departament i jego relacje, to ich łączna liczba (dla wszystkich urzędów marszałkowskich) niewiele przekracza liczbę 100, co stanowi całą populację generalną. W kontekście prowadzenia polityki rozwoju gospodarczego jednostki organizacyjne w administracji powiatowej i gminnej posiadają odmienne od poziomu regionalnego struktury, zadania i stosowane procedury. Zatem w przypadku podejmowania problemów badawczych w odniesieniu do zarządzania organizacją terytorialną, podejście ilościowe będzie trudne do zastosowania, ze względu na zbyt małą liczbę potencjalnych jednostek badawczych. Ponadto złożoność kontekstów podejmowanych problemów sprawia, że preferowane są takie metody badawcze, które umożliwiają jej uwzględnienie, czyli metody mieszane $\mathrm{z}$ wykorzystaniem technik jakościowych [Creswell 2013, s. 189-242].

Powyższe problemy sprawiają, że w przypadku organizacji publicznych o niewielkiej liczbie zasadne jest stosowanie metody studium przypadku, która przynajmniej w części pozwala na wyciąganie wniosków odnoszących się do problemów zarządzania publicznego. W takim przypadku nie wykorzystuje się jednostek wyselekcjonowanych w reżimie próby statystycznej, ale stosowane jest podejście replication approach [Yin 2009, s. 56]. Owa replikacja przypadków i przyglądanie się wycinkowi rzeczywistości z perspektywy różnych kontekstów pozwala zidentyfikować problemy, które inaczej nie byłyby możliwe do odkrycia. 
W kontekście badania organizacji terytorialnych polskich województw, które w niniejszym badaniu są utożsamiane w urzędami marszałkowskimi, pełniącymi ważną rolę zarówno w tworzeniu, jak i realizacji polityki rozwoju na szczeblu województwa, metoda studium przypadku wydaje się optymalna.

Entuzjastą stosowania metody studium przypadku w badaniach naukowych jest K. M. Eisenhardt [1989], [Eisenhardt, Graebner 2007, s. 25-32], która w swoich tekstach stara się ją popularyzować jako metodę, która sprawia, że podejmowane problemy naukowe są naprawdę interesujące. Podkreśla się równocześnie, że studia przypadków nie są najlepszą metodą dla szacowania popularności określonych praktyk/ działań/zachowań.

\subsection{Etapy badania oraz wykorzystywane metody i narzędzia badawcze}

Badania podzielono na trzy zasadnicze etapy. Jeśli pierwszy z nich ma charakter teoretyczny bądź opisowy, to kolejne dwa dotyczą rezultatów badań empirycznych prowadzonych przez autora. Na rys. 4.1 dokonano graficznej prezentacji tych etapów.

ETAP 1

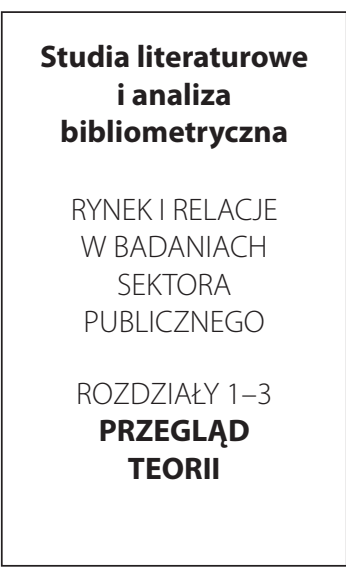

ETAP 2

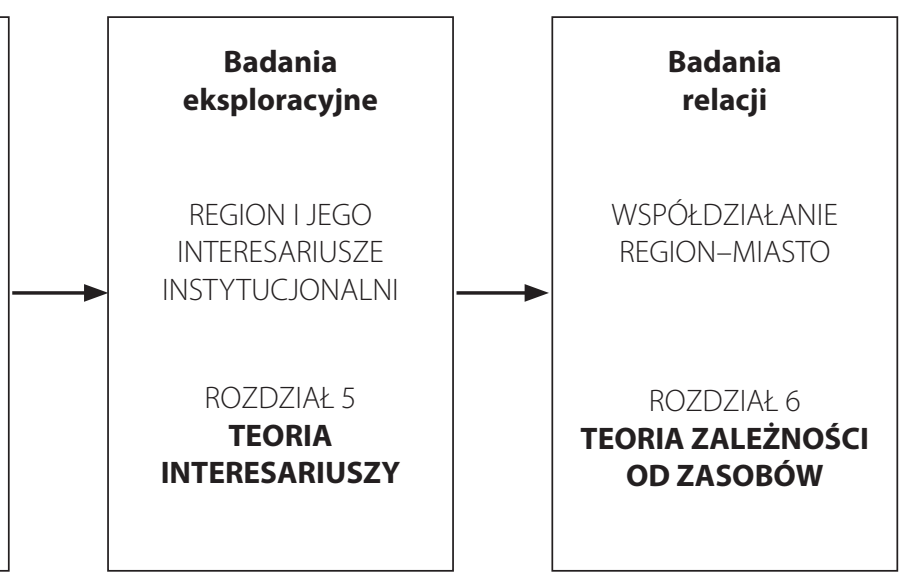

Rys. 4.1. Etapy prowadzonych badań

Źródło: badania własne. 
W dalszych rozważaniach dokonamy charakterystyki każdego z tych etapów, zwracając uwagę na przyjętą perspektywę teoretyczną, metodę badań i jej instrumenty badawcze oraz procedurę doboru przypadków do badań.

\subsubsection{Studia literaturowe i analiza bibliometryczna (etap 1)}

Podjęte w tym etapie studia literaturowe i bibliometryczne były zorientowane na dokonanie oceny dotychczasowego piśmiennictwa zagranicznego i krajowego w zakresie marketingu organizacji publicznych i węziej - marketingu terytorialnego oraz obecności tematyki rynku i wątku relacji w dyskursie naukowym dotyczącym sektora publicznego. Podjęte badania literaturowe (desk research) dotyczyły: zarządzania publicznego, marketingu w sektorze publicznym i terytorialnego, relacji międzyorganizacyjnych czy procesów governance. Badania miały potwierdzić istnienie luki badawczej w zakresie wykorzystywania teorii wyjaśniających relacje międzyorganizacyjne jako bazowe dla koncepcji marketingu terytorialnego. Rezultaty studiów literaturowych zamieszczono w rozdziałach $1-3$.

W ramach tego etapu badań przeprowadzono również studia bibliometryczne. Polegały one na określeniu liczby artykułów naukowych podejmujących problematykę sektora publicznego w wybranych czasopismach zagranicznych $\mathrm{z}$ listy JCR, które w poszczególnych latach dla okresu 1995-2014 posiadały w tzw. "słowach kluczowych” terminy dotyczące odpowiednio: rynku oraz relacji. Wykorzystano informacje $\mathrm{z}$ takich baz danych, jak: Journal Citation Report $\mathrm{w}$ ramach Web of Science oraz SCOPUS prowadzonej przez wydawnictwo ELSEVIER, będących w zasobach elektronicznych Biblioteki Uniwersytetu Łódzkiego w momencie zbierania danych. Procedura badawcza składała się z dwóch części. Najpierw zidentyfikowano listę najwyżej notowanych czasopism naukowych, umieszczanych w prestiżowych bazach bibliometrycznych, które podejmują problematykę sektora publicznego. Listę czasopism poddanych badaniu wraz z ich parametrami bibliometrycznymi umieszczono w załączniku 4.1. Następnie skoncentrowano się na analizie słów kluczowych każdego artykułu. $\mathrm{W}$ procesie badawczym postępowano według procedury opisanej w załączniku 4.2. 


\subsubsection{Badania eksploracyjne (etap 2)}

Większość badań realizowanych na tym etapie została ujęta w projekcie badawczym finansowanym ze środków MNiSW pt. Rola relacji partnerskich $w$ zarządzaniu regionem, którego kierownikiem był autor niniejszej monografii ${ }^{1}$. Zebrane wówczas dane (2009-2010) dotyczyły trzech województw, a mianowicie: małopolskiego, świętokrzyskiego oraz wielkopolskiego. W 2011 r. poszerzono próbę badawczą o województwo łódzkie, gdzie dodatkowo przeprowadzono badania przy użyciu tych samych instrumentów co wcześniej w pozostałych województwach. Za włączeniem uzyskanych w ten sposób danych do analizy przemawiał fakt, że w tym czasie województwo łódzkie nie zmieniło w istotny sposób swoich zasobów oraz miejsca w rankingu PKB per capita, a także, że warunki zewnętrzne (zasady polityki rozwoju), które stanowiły kontekst prowadzonych badań (dla okresu 2007-2013), były takie same. Warto dodać, że nie zmieniła się również opcja polityczna sprawowanej władzy w tym województwie. Uzyskano w ten sposób bogaty materiał obejmujący łącznie cztery polskie województwa.

\section{Cele badań oraz pytania i hipotezy badawcze}

Wypracowanie koncepcji MT w ujęciu relacyjnym wymagało podjęcia badań eksploracyjnych, umożliwiających bliższe poznanie roli współpracy w kontekście prowadzonej na szczeblu regionu polityki rozwoju, ze szczególnym uwzględnieniem działań podejmowanych przez jednostki organizacyjne urzędu marszałkowskiego.

Dla tego etapu badań sformułowano następujące cele szczegółowe:

C1a. Uzyskanie informacji na temat elementów otoczenia podmiotowego urzędu marszałkowskiego oraz wskazanie tych podmiotów publicznych (państwowe i samorządowe) oraz niepublicznych (społeczne i prywatne), z którymi współpraca jest szczególnie istotna dla realizacji polityki rozwoju województwa oraz określenie charakteru i potencjału takiej współpracy,

C2a. Identyfikacja jednostek organizacyjnych OT, które ze względu na powierzone im zadania muszą wchodzić w relacje z podmiotami rynkowymi i podejmować z nimi wspólne przedsięwzięcia,

C3a. Wykazanie, że tylko te jednostki organizacyjne OT, których zadania wymagają interakcji, prezentują relatywnie bardziej otwarte postawy ich kierownictwa wobec współdziałania $\mathrm{z}$ interesariuszami zewnętrznymi,

1 Projekt badawczy własny, numer rejestracyjny: N N115 248836, prowadzony na Uniwersytecie Łódzkim w latach 2009-2011. 
C4a. Identyfikacja rodzajów, zakresu oraz uwarunkowań rozwoju relacji międzyorganizacyjnych OT na szczeblu regionu,

C5a. Opracowanie modelu sześciu rynków dla OT na poziomie regionu w kontekście prowadzenia polityki rozwoju.

Realizacji tego celu miało służyć poznanie i usystematyzowanie relacji pomiędzy organizacją terytorialną na szczeblu województwa, w tym przede wszystkim jej aparatu administracyjnego (urząd marszałkowski), $\mathrm{z}$ jej interesariuszami instytucjonalnymi.

Badanie eksploracyjne miało przynieść odpowiedzi na następujące pytania badawcze:

Pytanie główne: Jakie są uwarunkowania relacji partnerskich OT w kontekście realizowanej polityki rozwoju oraz jakie grupy podmiotów uznać można za kluczowych potencjalnych partnerów do prowadzenia takiej polityki?

Poszukiwano również odpowiedzi na następujące pytania szczegółowe:

- Z jakimi rodzajami podmiotów OT na poziomie regionu kształtuje relacje zewnętrzne w kontekście prowadzonej polityki rozwoju?

- Jakie są pożądane zasoby w procesie współpracy międzyorganizacyjnej (perspektywa OT i perspektywa jej interesariuszy instytucjonalnych)?

- Jakie czynniki ułatwiają, a jakie utrudniają jednostkom organizacyjnym OT prowadzenie relacji międzyorganizacyjnych z ich interesariuszami instytucjonalnymi?

- Jakie postawy reprezentują menedżerowie publiczni w OT wobec partnerstwa międzyorganizacyjnego, $\mathrm{z}$ uwzględnieniem rodzajów reprezentowanych przez nich jednostek organizacyjnych?

- Jaki jest poziom otwartości OT na nowe relacje z podmiotami instytucjonalnymi?

Badanie prowadzone na czterech przypadkach organizacji terytorialnych (cztery urzędy marszałkowskie) oraz ich interesariuszy instytucjonalnych miało charakter eksploracyjny, a zarazem weryfikujący, w zakresie porównania postaw dyrektorów $\mathrm{z}$ różnych rodzajów jednostek organizacyjnych badanych OT.

Wiedza wypływająca ze studiów literaturowych, przeprowadzone badania pilotażowe oraz doświadczenia autora wyniesione ze współpracy z urzędami marszałkowskimi pozwoliły wyartykułować szczegółowe hipotezy, które zostały poddane weryfikacji w procesie badawczym:

H1a. Menedżerowie OT na szczeblu regionu posiadają zróżnicowane zdolności i kompetencje relacyjne oraz różną otwartość na współpracę zewnętrzną. Wyższe kompetencje w tym zakresie wykazują menedżerowie stojący na czele rynkowych jednostek organizacyjnych; 
H2a. Departamenty rynkowe, realizujące w istocie funkcje marketingowe, są relatywnie bardziej otwarte na współpracę z interesariuszami niepublicznymi niż publicznymi;

H3a. Podstawowym czynnikiem skłaniającym OT do współpracy z interesariuszami instytucjonalnymi jest możliwość korzystania z pozostających w ich dyspozycji zasobów, w celu realizacji zadań postawionych przed samorządem terytorialnym.

Na rys. 4.2 przedstawiono model sześciu rynków opracowany na początku lat 90. XX w. dla organizacji rynkowej. Celowo nie wypełniono poszczególnych pól rynków, co staje się zadaniem dla części eksploracyjnej badania. Istotne tu będzie zwłaszcza wskazanie najważniejszych rynków podmiotów, które dla OT na szczeblu regionu stanowią poszczególne grupy interesariuszy instytucjonalnych uczestniczące $w$ procesach rozwojowych. Zatem ich identyfikacja oraz określenie ich znaczenia dla prowadzonej przez region polityki rozwoju staje się jednym z wyzwań eksploracji podejmowanego problemu współpracy międzyorganizacyjnej OT.

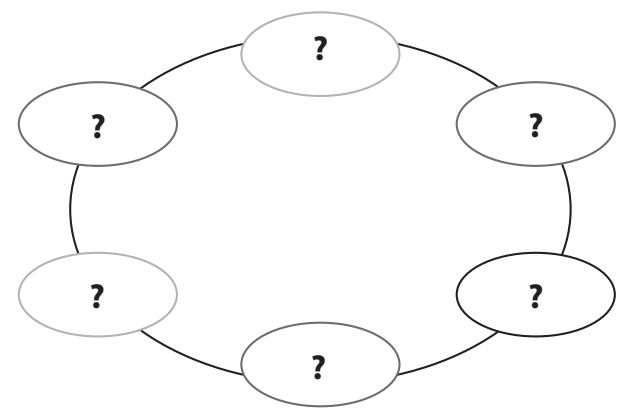

Rys. 4.2. Model sześciu rynków dla OT na szczeblu regionu

Źródło: opracowanie własne na podstawie [Christopher, Payne, Ballantyne 1991, s. 20].

Klasyczny model sześciu rynków stworzony dla biznesu zwraca uwagę na takie rynki interesariuszy, jak: klienci, dostawcy, pracownicy, podmioty wpływowe, dystrybutorzy oraz partnerzy strategiczni firmy. Poszerza on klasyczne rozumienie marketingu, że to klient jest jedynym podmiotem, o którego uwagę przedsiębiorstwo powinno zabiegać. W modelu tym uwaga firmy koncentruje się na różnych grupach interesariuszy w zależności od roli, jaką odgrywają w procesie dostarczania wartości klientowi.

\section{Dobór próby badawczej}

W drugim etapie do badań wybrano początkowo trzy województwa, zaś po dwóch latach, jak wspominaliśmy, dołączono czwarte. Potencjał reprezentowany przez poszczególne województwa oraz stopień zaspakajania 
potrzeb poszczególnych grup użytkowników zewnętrznych nadal pozostaje zróżnicowany. Pokazują to wyniki kolejnych rankingów atrakcyjności inwestycyjnej, turystycznej czy akademickiej poszczególnych województw. Przy dokonywaniu wyboru brano pod uwagę takie kryteria, jak: wskaźniki rozwoju społeczno-gospodarczego, lokalizację regionów na obszarach byłych zaborów oraz relatywną bliskość jednostki, dla której prowadzone było badanie (Uniwersytet Łódzki). Biorąc pod uwagę pierwsze z wymienionych kryteriów, postanowiono dokonać wyboru województw, które reprezentują różne poziomy rozwoju społeczno-gospodarczego.

Dane dotyczące PKB per capita (GUS 2008) dla każdego z województw pozwoliły wyodrębnić następujące ich grupy: (1) o wysokim poziomie rozwoju gospodarczego (śląskie, dolnośląskie, wielkopolskie); (2) o średnim poziomie rozwoju (pomorskie, łódzkie, zachodniopomorskie, małopolskie, kujawsko-pomorskie, lubuskie, opolskie) oraz (3) o słabym poziomie rozwoju (świętokrzyskie, warmińsko-mazurskie, podlaskie, lubelskie, podkarpackie). Województwo mazowieckie, ze względu na wyraźnie korzystniejszą sytuację społeczno-gospodarczą oraz jego specyficzne cechy, wyłączono ze wspomnianych grup, traktując je jako przypadek nietypowy.

W doborze organizacji terytorialnych uwzględniono również lokalizację na terenach historycznie znajdujących się w jednym z trzech zaborów. Kryterium takie ma związek $\mathrm{z}$ faktem, że mieszkańców obszarów będących niegdyś w różnych zaborach nadal charakteryzuje odmienny poziom zaufania społecznego, inna aktywność społeczna, ale też dostrzega się różnice w preferencjach politycznych. Wszystko to może mieć wpływ na relacje międzyorganizacyjne [Jałowiecki 2010]. Wreszcie przy wyborze organizacji terytorialnych do badań wykorzystano fakt relatywnej bliskości badanych organizacji terytorialnych do miejsca pracy kierownika projektu badawczego, czyli do Uniwersytetu Łódzkiego. Autor zamierzał bowiem część wywiadów przeprowadzić samodzielnie, a zbyt duża odległość do wybranego województwa mogła to zadanie utrudnić i zwiększyć koszty badania.

W oparciu o wspomniane kryteria do badań wybrano jedną organizację terytorialną reprezentującą region atrakcyjny (Urząd Marszałkowski Województwa Wielkopolskiego), dwie organizacje terytorialne reprezentujące najliczniejszą grupę regionów - o średniej atrakcyjności (Urząd Marszałkowski Województwa Łódzkiego, Urząd Marszałkowski Województwa Małopolskiego) oraz organizację terytorialną o relatywnie niskiej atrakcyjności (Urząd Marszałkowski Województwa Świętokrzyskiego). Daje to możliwość zaobserwowania zjawisk i procesów oraz postaw respondentów dotyczących międzyorganizacyjnego współdziałania $\mathrm{w}$ organizacjach terytorialnych, dysponujących różnorodnymi zasobami. 
Województwo wielkopolskie było historycznie związane z zaborem pruskim, stąd poziom zaufania społecznego i przedsiębiorczości jest tam relatywnie wysoki wobec pozostałych. Zarówno województwo świętokrzyskie, jak i województwo łódzkie były związane głównie z zaborem rosyjskim. Społeczeństwo zamieszkujące były zabór rosyjski, ze względu na wspomniane zaszłości historyczne, charakteryzuje się niższym poziomem zaufania, co nie sprzyja tworzeniu kapitału społecznego, będącego współcześnie podstawą dla budowania kompetencji relacyjnych organizacji terytorialnej. Natomiast większość terytorium obecnego województwa małopolskiego związana była $\mathrm{z}$ zaborem austriackim, gdzie poziom zaufania wobec wyżej wymienionych można określić jako pośredni.

\section{Badania pilotażowe}

Badania poprzedzono pilotażem, który przeprowadzono w łódzkim urzędzie marszałkowskim. Wybór tego urzędu został podyktowany nie tylko względami logistycznymi (bliskość uczelni autora), ale również faktem, że województwo łódzkie sytuuje się, pod względem wskaźników rozwoju społeczno-gospodarczego, na średnim poziomie w kraju. W ramach badania pilotażowego przeprowadzono wywiady otwarte $\mathrm{z}$ dyrektorami poszczególnych departamentów urzędu marszałkowskiego, których zadania wpisują się w badany zakres polityki rozwoju województwa. Osoby te, realizując swoje zadania, współpracują z różnymi podmiotami $\mathrm{w}$ ramach urzędu, $z$ interesariuszami instytucjonalnymi z regionu i interesariuszami spoza regionu (np. ze szczebla centralnego).

$\mathrm{Na}$ etapie pilotażu zidentyfikowano typowe podmioty pozostające $\mathrm{w}$ relacji z organizacją terytorialną $\mathrm{w}$ kontekście prowadzonej polityki rozwoju, a także określono typowe uwarunkowania i ich cechy. Badaniem pilotażowym zostali objęci również wybrani partnerzy samorządu województwa łódzkiego, tacy jak: instytucje publiczne działające w regionie, samorządy lokalne, organizacje pozarządowe i partnerzy gospodarczy. W przeprowadzonych z nimi wywiadach uwzględniono problematykę korzyści, jakie spodziewają się uzyskać ze współpracy z samorządem regionu. Uwzględniono w nich również formy i intensywność takiej współpracy. Podstawowy instrument wykorzystywany na tym etapie badań to wywiad bezpośredni ze standaryzowaną listą poszukiwanych informacji. Wywiady trwały zwykle $1-1,5$ godziny. Były prowadzone w siedzibach badanych organizacji (w Urzędzie Marszałkowskim Województwa Łódzkiego oraz siedzibach interesariuszy instytucjonalnych), rejestrowane, a następnie dokonano ich transkrypcji.

Badania pilotażowe umożliwiły przygotowanie szczegółowej koncepcji badań oraz instrumentów badawczych. W badaniu wykorzystano metodę wielokrotnego studium przypadku, gdzie przypadkami były samorządy wojewódzkie w ich wymiarze organizacyjnym. 


\section{Techniki i narzędzia badawcze}

W ramach metody wielokrotnego studium przypadku wykorzystano następujące techniki badawcze:

- wywiady standaryzowane (prowadzone przez ankieterów) w urzędach marszałkowskich,

- wywiady standaryzowane prowadzone $\mathrm{w}$ organizacjach publicznych i niepublicznych - tzw. interesariuszy instytucjonalnych OT, w procesie prowadzenia polityki rozwoju,

- technikę „tajemniczy klient” (mystery client) zastosowaną w zapytaniu o informację publiczną (dotyczącą działań marketingowych) skierowanym do badanych urzędów marszałkowskich.

Badania dotyczyły eksploracji postaw wobec relacji międzyorganizacyjnych zarówno menedżerów publicznych, jak i zarządzających organizacjami interesariuszy instytucjonalnych. Mimo relatywnie małej grupy respondentów, autor zdecydował się na ilościowe rozpoznanie otrzymanych wyników, dzieląc badane jednostki organizacyjne OT na: rynkowe (RYN), sektorowe (SEK) i administracyjne (ADM). Zasadność tej klasyfikacji oraz charakterystykę poszczególnych rodzajów departamentów opisano w podrozdziale dotyczącym operacjonalizacji pojęć.

$\mathrm{W}$ ramach badania w urzędach marszałkowskich wykorzystano narzędzie badawcze w postaci wywiadu standaryzowanego strukturalizowanego. Kwestionariusz wywiadu został umieszczony w załączniku 5.1. Wywiady zostały przeprowadzone w sposób bezpośredni, przez ankieterów w latach 2009-2011 w siedzibach tych organizacji. W ramach badania przeprowadzono również wywiady z przedstawicielami zarządów województw (organ wykonawczy) w każdym $\mathrm{z}$ badanych regionów.

Wywiady z interesariuszami instytucjonalnymi samorządu województwa (łącznie 42) miały miejsce w ich siedzibach. Respondentami byli szefowie tych organizacji, a w przypadku braku takiej możliwości - menedżerowie wyższego szczebla. Również w ich przypadku wykorzystano narzędzie wywiadów strukturalizowanych $\mathrm{z}$ wysokim stopniem standaryzacji. Zastosowany tu kwestionariusz miał podobną strukturę, co ten umieszczony w załączniku 5.1, dlatego nie załączono go jako oddzielnego dokumentu. Wywiady były rejestrowane, a następnie dokonano ich pełnej transkrypcji. Wywiady bezpośrednie przeprowadzono również z przedstawicielami administracji państwowej w Warszawie z wybranych ministerstw (MSWiA, MRR) i agencji rządowych (PAIiIZ), które są uczestnikami relacji międzyorganizacyjnych z samorządem województwa w kontekście prowadzenia polityki rozwoju województwa.

Ostatecznie wykorzystano czterdzieści dwa wywiady z interesariuszami zewnętrznymi. Dwa wywiady przeprowadzone przez jednego $\mathrm{z}$ ankieterów (Opera Krakowska, Krakowski Szpital Specjalistyczny) uznano 
za nieprzydatne w kontekście założeń badawczych, bowiem podmioty te są instytucjonalnie powiązane $\mathrm{z}$ samorządem regionu, co powodowałoby oczywiste trudności przy interpretacji wyników. Z grupy respondentów dwadzieścia osiem osób to mężczyźni, a czternaście - kobiety. Osoby przeprowadzające wywiady odnotowywały wiek respondentów. Tylko jeden respondent znalazł się w przedziale wieku do 30 lat. Ponad połowa badanych to osoby powyżej 50 roku życia. Spośród podanych przedziałów wiekowych, najwięcej respondentów znalazło się w przedziale 51-60 lat (30,95\%).

Jednostkami analizy były departamenty OT i organizacje zewnętrzne - interesariusze instytucjonalni OT. Wybrano te departamenty, które bezpośrednio lub pośrednio uczestniczyły w realizacji szeroko rozumianej polityki rozwoju, ze szczególnym wskazaniem na rozwój gospodarczy². Do wyboru tego wykorzystano zapisy regulaminów organizacyjnych poszczególnych urzędów marszałkowskich. Jako respondentów dobrano menedżerów publicznych stojących na czele komórek organizacyjnych OT. Natomiast przy wyborze tzw. kluczowych interesariuszy instytucjo-

2 W przypadku województwa tódzkiego wywiady przeprowadzono z dyrektorami następujących jednostek urzędu marszałkowskiego: Departament ds. RPO, Departament PO KL, Departament Polityki Regionalnej, Departament Rolnictwa i Ochrony Środowiska, Departament Polityki Zdrowotnej, Departament Organizacyjny, Departament Kultury Fizycznej, Sportu i Turystyki, Departament Finansowy, Departament Geodezji i Kartografii, Departament Infrastruktury, Departament Promocji i Współpracy z Zagranicą, Departament Funduszu Rozwoju Obszarów Wiejskich, Kancelaria Marszałka, Departament Edukacji i Kultury, Departament Przedsiębiorczości. W przypadku województwa małopolskiego wywiady przeprowadzono z dyrektorami następujących jednostek urzędu marszałkowskiego: Departament Polityki Regionalnej, Departament Promocji i Turystyki, Departament Rolnictwa i Geologii, Departament Edukacji i Sportu, Departament Zdrowia i Polityki Społecznej, Kancelaria Zarządu, Departament Gospodarki i Społeczeństwa Informacyjnego, Departament Kultury i Dziedzictwa Narodowego, Departament Środowiska i Rozwoju Obszarów Wiejskich, Departament Inwestycji Regionalnych, Departament Transportu i Komunikacji, Departament Funduszy Europejskich. W przypadku województwa świętokrzyskiego wywiady przeprowadzono z dyrektorami następujących jednostek urzędu marszałkowskiego: Departament Polityki Regionalnej, Departament Funduszy Strukturalnych, Departament Infrastruktury, Departament Rozwoju Obszarów Wiejskich i Środowiska, Departament Promocji, Edukacji, Kultury, Sportu i Turystyki, Biuro Komunikacji Społecznej, Zespół ds. Informatyzacji Województwa, Regionalny Ośrodek Polityki Społecznej i Zdrowotnej. W przypadku województwa wielkopolskiego wywiady przeprowadzono z dyrektorami następujących jednostek urzędu marszałkowskiego: Departament Polityki Regionalnej, Departament Gospodarki, Departament Środowiska, Departament Transportu, Departament Wdrażania Wielkopolskiego Regionalnego Programu Operacyjnego, Departament Kultury, Departament Organizacji i Kadr, Departament Rolnictwa i Rozwoju Wsi. 
nalnych dla badanych organizacji terytorialnych wykorzystano technikę kuli śnieżnej. Poszczególni dyrektorzy badanych departamentów urzędów marszałkowskich wskazywali organizacje, z którymi współpracują przy realizacji polityki rozwoju. Do tej grupy respondentów zaliczono również organizacje niewskazane przez wspomnianych dyrektorów, a które w opinii badacza wydają się mieć duży wpływ na realizowaną politykę rozwoju ${ }^{3}$. Pozwoliło to zapobiec ryzyku, że w badanej grupie interesariuszy instytucjonalnych znajdą się tylko te organizacje, z którymi urząd marszałkowski pozostaje w modelowych relacjach.

\section{Badanie techniką „tajemniczy klient”}

Do oszacowania otwartości na inne podmioty instytucjonalne badanych organizacji terytorialnych (urzędów marszałkowskich) wykorzystano technikę „tajemniczy klient” (mystery client). Badanie zostało dostosowane do głównego przedmiotu pracy, jakim jest kształtowanie ze-

3 W województwie tódzkim wywiady przeprowadzono z szefami następujących organizacji: Regionalna Izba Gospodarcza, Łódzka Izba Przemysłowo-Handlowa, Polskie Towarzystwo Ekonomiczne Oddział w Łodzi, Urząd Wojewódzki, Centrum Innowacji UŁ, Urząd Miasta Łodzi, Urząd Miasta Pabianice. W województwie małopolskim wywiady przeprowadzono z szefami następujących organizacji: Stowarzyszenie Gmin i Powiatów Małopolski, TVP Kraków, Urząd Miasta Krakowa (Biuro Funduszy Europejskich), Urząd Wojewódzki, Kuratorium Oświaty, Małopolska Agencja Rozwoju Regionalnego, Uniwersytet Jagielloński, Małopolska Izba Rzemiosła i Przedsiębiorczości, Izba Przemysłowo-Handlowa w Krakowie. W województwie świętokrzyskim wywiady przeprowadzono z szefami następujących organizacji (interesariuszy instytucjonalnych województwa): Targi Kielce, Konwent Starostów Województwa Świętokrzyskiego, Urząd Gminy Morawica, Staropolska Izba Przemysłowo-Handlowa, Związek Miast i Gmin Regionu Świętokrzyskiego, Kielecki Park Technologiczny, Regionalna Organizacja Turystyczna, Politechnika Świętokrzyska, Uniwersytet Humanistyczno-Przyrodniczy Jana Kochanowskiego, Wyższa Szkoła Ekonomii i Prawa im. prof. Edwarda Lipińskiego w Kielcach, Świętokrzyskie Centrum Innowacji i Transferu Technologii. W województwie wielkopolskim wywiady przeprowadzono z szefami następujących organizacji: Urząd Miasta Poznania, Starostwo Powiatu Czarnkowsko-Trzcianeckiego, Urząd Miejski w Kórniku, Sejmik Gospodarczy Województwa Wielkopolskiego, Uniwersytet Medyczny w Poznaniu, Centrum Badań DNA, Uniwersytet Ekonomiczny w Poznaniu, Politechnika Poznańska. W ramach projektu przeprowadzono również wywiady kwestionariuszowe z partnerami zewnętrznymi polskich organizacji terytorialnych na szczeblu regionu: Komisja Europejska (DG Employment), Ministerstwo Spraw Wewnętrznych i Administracji (Departament Unii Europejskiej i Współpracy Międzynarodowej), Polska Agencja Informacji i Inwestycji Zagranicznych (Departament Rozwoju Regionalnego), Ministerstwo Spraw Wewnętrznych i Administracji (Departament Administracji Publicznej), Ministerstwo Rozwoju Regionalnego (Departament Koordynacji i Wdrażania Programów Regionalnych), Ministerstwo Rozwoju Regionalnego (Departament Koordynacji Polityki Strukturalnej). 
wnętrznych relacji organizacji terytorialnej w procesie generowania rozwoju gospodarczego. Obserwacja ta stanowi ilustrację wybranej relacji region-jednostka naukowo-badawcza. W celu poznania reakcji urzędu marszałkowskiego na prośbę o informację publiczną, podjęto działania zmierzające do stworzenia realistycznej sytuacji. Nawiązano kontakt z rzeczywistą organizacją naukowo-badawczą działającą w Brukseli na rynku badań międzynarodowych i poproszono ją o współpracę przy realizacji badania techniką „tajemniczy klient”. Organizacja ta skierowała imienne zapytanie do każdego z marszałków badanych województw. Zapytanie zostało wysłane za pośrednictwem poczty e-mail z załączonym pismem $w$ języku angielskim na papierze firmowym tej organizacji. Pismo zawierało krótki opis przyczyny, dla której zwrócono się z prośbą o informacje (badanie pilotażowe przed szerokim badaniem konkurencyjności regionów europejskich) oraz listę pięciu pytań. Treść pytań dobrano w taki sposób, aby uwzględniając standardowy podział organizacyjny urzędów marszałkowskich, udzielenie odpowiedzi wymagało merytorycznego udziału przynajmniej dwóch departamentów, które realizują szeroko rozumiane funkcje marketingowe (departament odpowiedzialny za promocję - problematyka budowania marki, departament odpowiedzialny za tworzenie warunków dla inwestorów/przedsiębiorców - problematyka gospodarcza). Podjęte w pytaniach wątki dotyczyły tematów aktualnych dla wszystkich samorządów wojewódzkich w Polsce, takich jak: sojusze strategiczne samorządów wojewódzkich, inteligentne specjalizacje (smart specialisations) czy wartości marki gospodarczej

Tabela 4.1. Obszary oceny responsywności badanych organizacji terytorialnych techniką „tajemniczy klient” (mystery client)

\begin{tabular}{|l|l|}
\hline \multicolumn{1}{|c|}{ Obszar oceny } & \multicolumn{1}{c|}{ Szczegółowe kryterium oceny } \\
\hline \multirow{3}{*}{ TERMINOWOŚĆ } & niezwłocznie \\
\hline \multirow{4}{*}{ TREŚĆ i FORMA ODPOWIEDZI } & do 15 dni / 16-30 dni / 31-60 dni / 61-90 dni \\
\hline & merytorycznie wyczerpująca / niewyczerpująca \\
\cline { 2 - 3 } & jęz. ang. / jęz. pol. \\
\cline { 2 - 3 } & mailowo / pismem na papierze firmowym \\
\cline { 2 - 2 } & formalny / nieformalny styl odpowiedzi \\
\hline \multirow{3}{*}{ OTWARTOŚĆ RELACYJNA } & przejawy zainteresowania pytającym \\
\cline { 2 - 3 } & prośba o doprecyzowanie zapytania \\
\cline { 2 - 2 } & prośba o przesłanie rezultatów badań \\
\cline { 2 - 2 } & zachęcenie do dalszego kontaktu \\
\hline
\end{tabular}

Źródło: opracowanie własne. 
województwa. Postanowiono skonfrontować deklarowaną otwartość urzędów marszałkowskich na relacje zewnętrzne oraz poznać procesy związane z procedowaniem, w kierunku przygotowania odpowiedzi i nawiązania relacji z podmiotem pytającym. Badanie trwało $90 \mathrm{dni}$, od początku czerwca do początku września, zaś jego rezultaty zaprezentowano w rozdziale piątym.

W ramach tej techniki badawczej sformułowano szereg szczegółowych kryteriów oceny zachowań przedstawicieli pytanej organizacji terytorialnej, dla takich obszarów jak: terminowość, treść i forma odpowiedzi oraz otwartość relacyjna. Szczegółowe kryteria oceny umieszczono w tab. 4.1.

\subsubsection{Badanie relacji region-miasto (etap 3)}

W trzecim etapie badań skoncentrowano się na relacji OT na szczeblu regionu $\mathrm{z}$ wybranym interesariuszem instytucjonalnym. Autor zdaje sobie sprawę z tego, że każda relacja z poszczególnymi interesariuszami instytucjonalnymi jest inna, specyficzna. Zatem relacje te należy opisywać przy użyciu innych teorii, adekwatnych do charakteru danej relacji. Autor, bazując na wynikach badań zrealizowanych w etapie 2, wykazał, że uniwersytety oraz lokalne JST to te rynki interesariuszy, z którymi współdziałanie ma zwykle miejsce w wielu obszarach. Zdecydowano się na drugi $z$ wymienionych, wybierając specyficzną relację region-miasto (stolica regionu). Za wyborem takim przemawiają następujące cechy tej relacji, świadczące o jej znaczeniu dla współdziałania w marketingowym procesie przyciągania mobilnych czynników wzrostu:

- jest to relacja formalnie bez zwierzchności żadnej ze stron. Z perspektywy regionu oraz zgodnie z przepisami, stolica jest stawiana w jednym szeregu ze wszystkimi lokalnymi JST, jakie funkcjonują w regionie;

- stolica, ze względu na posiadane zasoby, jest potencjalnie najważniejszym partnerem spośród lokalnych JST dla OT na szczeblu województwa, w kontekście realizacji procesów rozwojowych. Region, chcąc skutecznie budować potencjał gospodarczy, musi podejmować współdziałanie nieformalne ze stolicą w kierunku osiągnięcia wspólnych korzyści;

- samorząd terytorialny na szczeblu województwa jest tym szczeblem władzy, który nabiera znaczenia ze względu na zadania w zakresie prowadzenia polityki rozwoju wspieranej z funduszy unijnych;

- samorząd województwa wykonuje relatywnie mało typowych usług publicznych dla mieszkańców; jego zadania koncentrują się na tworzeniu warunków do rozwoju oraz koordynacji działań zorientowanych 
na wykorzystywanie zasobów pozostających w rękach interesariuszy instytucjonalnych, na rzecz rozwoju województwa;

- relacje region-miasto są już przedmiotem dyskursu naukowego w Polsce [Brzeziński 2010], co czyni zasadnym podejmowanie nowych prób opisu naukowego tych relacji.

Powyższe cechy wskazują jednoznacznie, że wybór tej kluczowej relacji pomiędzy regionem a miastem-stolicą, w kontekście prowadzenia działań marketingowych regionu na rzecz przyciągania inwestorów, turystów i studentów jest w pełni uzasadniony. Uzasadniony jest również istnieniem strukturalnych antagonizmów pomiędzy regionem i metropolią [Brzeziński 2010], co bezpośrednio wpływa na proces współdziałania pomiędzy oboma OT. To sprawia, że spełnione są warunki do analizy tych relacji z perspektywy teorii zależności od zasobów [Pfeffer, Salancik 1978]. Za wykorzystaniem tej teorii przemawiają takie cechy powyższej relacji, jak:

- występowanie antagonizmów pomiędzy regionem i miastem, wzmacnianych reprezentowaniem przez władze wykonawcze (zarządu województwa i prezydenta miasta) odmiennych opcji politycznych;

- miasto-stolica regionu jest często kluczowym ośrodkiem dla konkurencyjności regionu w wymiarze inwestycyjnym, turystycznym czy akademickim;

- wcześniejsze badania wykazały, że współdziałanie OT na szczeblu regionu $\mathrm{z}$ interesariuszami instytucjonalnymi jest powszechne, ale motywy tych działań są związane głównie z finansowymi instrumentami polityki spójności UE oraz chęcią wzmocnienia pozycji własnej organizacji. Rzadziej natomiast motywy te wypływają $\mathrm{z}$ chęci uwzględnienia interesu interesariuszy, co jest podstawowym założeniem przy stosowaniu alternatywnej - teorii wymiany relacyjnej dla opisu współdziałania.

\section{Cele badań oraz pytania i hipotezy badawcze}

Dla tego etapu badań sformułowano następujący cel:

C1b. Określenie wpływu wielkości udziałów zasobów stolicy w regionie na poziom współdziałania regionu $\mathrm{z}$ miastem $\mathrm{w}$ kontekście realizacji przez region procesów marketingowych zorientowanych na pozyskiwanie inwestorów, turystów i studentów.

Niżej wyszczególniono pytania badawcze, odnoszące się do tej specyficznej relacji, w kontekście procesów pozyskiwania inwestorów, turystów i studentów do regionu:

1. Jakie są relacje region-miasto w wymiarze organizacyjnym, w kontekście marketingowych procesów przyciągania do regionu jego potencjalnych użytkowników? 
2. Jak deficyt zasobów i władzy wpływa na współdziałanie organizacji terytorialnych w procesach marketingowych, rozumianych jako działania na rzecz podnoszenia pozycji konkurencyjnej terytorium, poprzez pozyskiwanie mobilnych zasobów wzrostu z zewnątrz?

3. Jakie są uwarunkowania strategicznego partnerstwa region-miasto $\mathrm{w}$ wymiarze organizacyjnym, w marketingowym procesie pozyskiwania zewnętrznych czynników wzrostu?

4. Jak wielkość zasobów ważnych dla inwestorów, turystów, studentów, będących w dyspozycji lub pod wpływem miasta, wpływa na poziom współdziałania regionu $\mathrm{z}$ miastem, $\mathrm{w}$ kontekście procesów marketingowych prowadzonych przez region?

Dla tego etapu badań sformułowano następującą hipotezę badawczą:

H1b. Skłonność OT na szczeblu regionu do budowania partnerstwa $\mathrm{z}$ miastem (stolicą), $\mathrm{w}$ marketingowym procesie przyciągania mobilnych czynników wzrostu, rośnie wraz ze znaczeniem stolicy w regionie ze względu na posiadane lub kontrolowane przez nią zasoby, ważne z punktu widzenia inwestorów, turystów i studentów.

\section{Metody i narzędzia badawcze}

W trzecim etapie badań wykorzystano metodę wielokrotnego studium przypadku, ukierunkowaną na badanie relacji region-miasto (stolica regionu). Dzięki projektowi badawczemu pt.: Marketing jako operacyjne rozwinięcie koncepcji governance $w$ zarządzaniu publicznym ${ }^{4}$ możliwe było zebranie materiału badawczego aż w ośmiu województwach. Wykorzystano następujące techniki badawcze:

- wywiady pogłębione (prowadzone przez ankieterów) w urzędach marszałkowskich;

- wywiady pogłębione w urzędach miast (stolic regionów), a także w organizacjach publicznych i niepublicznych, stanowiących interesariuszy instytucjonalnych dla regionu w procesach marketingowych, zorientowanych na pozyskiwanie inwestorów, turystów i studentów;

- analiza dyskursu strategicznego - dokumentów zastanych o charakterze strategicznym (strategie rozwoju województw) i operacyjnym (Regionalne Programy Operacyjne), które zostały poddane analizie treści jawnych;

- desk research $\mathrm{w}$ odniesieniu do strategicznych działań marketingowych badanych regionów i miast, z wykorzystaniem publikacji

4 Projekt numer N N115 364339, finansowany przez Ministra Nauki i Szkolnictwa Wyższego, realizowany w latach 2010-2012, którego autor monografii był współrealizatorem. 
urzędowych, zawartości stron internetowych oraz materiałów wewnętrznych udostępnionych przez urzędy;

- zapytanie o informację publiczną skierowane do wybranych (badanych) urzędów marszałkowskich i miejskich dotyczącą kierunków współpracy zagranicznej (regiony partnerskie, miasta partnerskie).

\section{Dobór próby badawczej}

Doboru relacji do badań dokonano z uwzględnieniem teorii zależności od zasobów, która stała się teoretyczną podstawą rozważań nad współdziałaniem $\mathrm{w}$ procesach pozyskiwania mobilnych czynników wzrostu opisanych $\mathrm{w}$ rozdziale szóstym. Bazuje ona na przekonaniu, że pomiędzy organizacjami istnieją współzależności, w sytuacji gdy jedna z nich (np. interesariusz instytucjonalny OT) $\mathrm{w}$ danym obszarze jest właścicielem lub posiada kontrolę nad zasobami potrzebnymi innej organizacji do realizacji wytyczonych przez nią celów. Warto zauważyć, że przykładowo w przypadku rynku turystów to miasto-stolica regionu jest organem prowadzącym dla większości instytucji kultury i zarządcą infrastruktury miejskiej, a także odpowiada za organizację lokalnego transportu itp. Natomiast sektor hoteli, restauracji, atrakcji turystycznych to domena prywatnych przedsiębiorców.

Do badania relacji pomiędzy OT na szczeblu regionu i jego stolicą w marketingowym procesie pozyskiwania czynników wzrostu starano się dobrać przypadki, których zasoby różnicują potencjał stolicy województwa względem reszty regionu. Potencjał ten jest wyrażany m.in. w funkcjach metropolitarnych, jakie pełni dana stolica województwa oraz w jej cechach statystycznych, dotyczących liczby przedsiębiorstw, turystów, studentów wobec zasobów całego regionu.

Do określenia potencjału metropolitarnego stolic regionów wykorzystano klasyfikację miast opracowaną przez EUROREG w 2009 r., w ramach której wyodrębniono trzy ich grupy: (1) ośrodki metropolitarne, (2) centra regionalne klasy A oraz (3) centra regionalne klasy B. Przy dokonywaniu tej klasyfikacji uwzględnione zostały następujące kryteria: liczba ludności, potencjał akademicki, potencjał kulturalny, jakość zarządzania, podejmowane działania zewnętrzne (np. lotnicze) [Smętkowski, Gorzelak, Jałowiecki 2009, s. 47].

Do badań wybrano ośrodki reprezentujące każdą z grup, przy czym niektóre nie zaklasyfikowano do badań ze względu na ich nietypowy charakter. Z badania wyłączono Warszawę (mazowieckie) w związku $\mathrm{z}$ istotną różnicą $\mathrm{w}$ potencjale społeczno-gospodarczym, zdecydowanie odbiegającym od pozostałych miast w Polsce. Za tą decyzją przemawia również specyfika stołeczności Warszawy. Trójmiasto (pomorskie) i Konurbacja Śląska (śląskie, dolnośląskie) nie zostały uwzględnione, ponie- 
waż realizacja celów badania wymagałaby przeprowadzenia wywiadów we wszystkich miastach wchodzących w skład tych układów. Z powodu podziału kompetencji samorządowych pomiędzy Toruń i Bydgoszcz w województwie kujawsko-pomorskim również zdecydowano się wyłączyć te miasta $\mathrm{z}$ badania.

Wyselekcjonowano natomiast następujące województwa:

- zawierające ośrodki metropolitarne: małopolskie (Kraków), łódzkie (Łódź), wielkopolskie (Poznań) o silnym potencjale stolicy;

- zawierające ośrodki regionalne klasy A: lubelskie (Lublin), zachodniopomorskie (Szczecin) o średnim potencjale stolicy;

- zawierające ośrodki regionalne klasy B: warmińsko-mazurskie (Olsztyn), świętokrzyskie (Kielce), podkarpackie (Rzeszów) o słabym potencjale stolicy.

Wszystkie wyselekcjonowane $\mathrm{w}$ ten sposób województwa poddano w rozdziale szóstym badaniom pod kątem udziału zasobów stolicy w zasobach regionu oddzielnie na rynkach: inwestycyjnym, turystycznym i akademickim. Analizy te pozwoliły na dokonanie klasyfikacji regionów ze względu na udział stolicy w zasobach regionu ogółem i ich podział na regiony o wysokim, średnim oraz niskim potencjale stolicy w regionie.

Kierując się metodyką doboru studiów przypadków, preferującą dobór skrajnych przypadków [Czakon 2013, s. 103-105], zdecydowano się dobrać przypadki reprezentujące dwie możliwie skrajne sytuacje. Pierwsza (przypadek A) to sytuacja, gdy stolica regionu jest relatywnie silniejsza na tle województwa w kontekście atrakcyjności dla inwestorów, turystów i studentów. Atrakcyjność ta jest mierzona poprzez lokalizację ważnych z perspektywy inwestorów, turystów i studentów zasobów związanych $\mathrm{z}$ danym terytorium. Natomiast do drugiej skrajnej sytuacji (przypadek B) zaliczono województwa, w których rola stolicy na tle województwa jest relatywnie słabsza pod względem tych zasobów.

Obie grupy zaprezentowano schematycznie na rys. 4.3. Obserwacje prowadzono na poziomie podstawowych jednostek organizacyjnych departamentów w urzędach marszałkowskich oraz ich odpowiedników w urzędach miast (wydziałach). Chociaż przy doborze przypadków nie koncentrowano się na wymiarze politycznym współdziałania, to warto zauważyć, że w większości relacji region-stolica władze wykonawcze samorządu województwa i samorządu miasta są do siebie w opozycji, o czym świadczą dane umieszczone w załączniku 4.3, dotyczące kadencji 2010-2014. W jednym tylko przypadku, w województwie łódzkim, mamy do czynienia $\mathrm{z}$ formalną zgodnością opcji politycznej reprezentowanej przez marszałka województwa oraz prezydenta miasta, ale w praktyce - uwzględniając podziały polityczne w Platformie Obywatelskiej i w tym przypadku nie ma zgodności. 

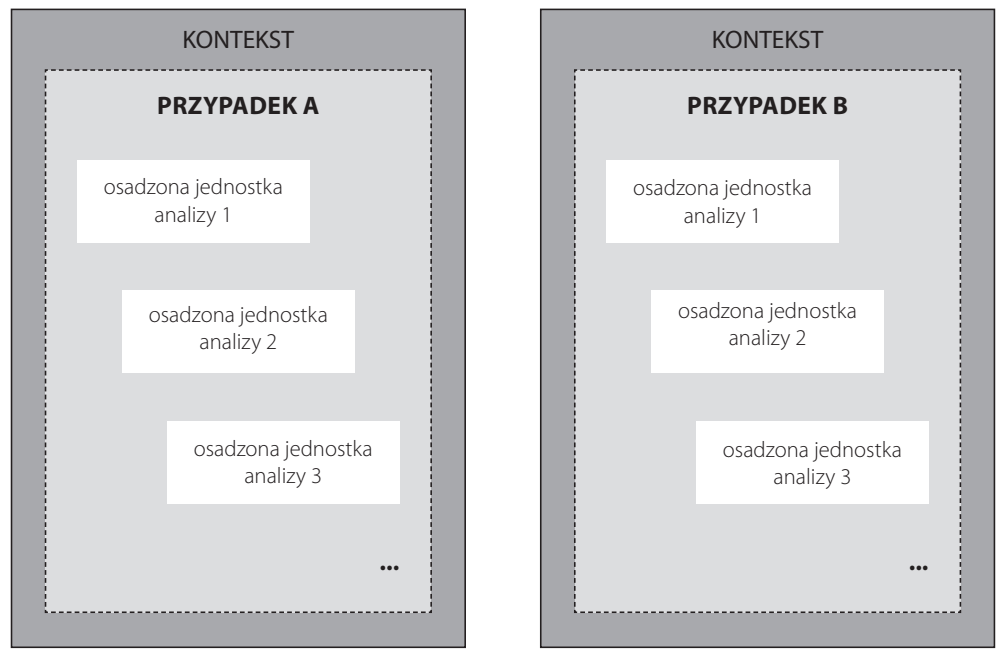

Rys. 4.3. Wielokrotne studium przypadku dla relacji region-miasto (stolica regionu)

Źródło: opracowanie własne na podstawie [Yin 2009, s. 46].

W badaniu skoncentrowano się na ocenie przebiegu współdziałania na poziomie departamentów rynkowych (RYN) w organizacji terytorialnej oraz postrzeganiu tego procesu przez uczestników tych relacji - menedżerów publicznych, w osobach dyrektorów departamentów urzędu marszałkowskiego z jednej strony i kierujących organizacjami interesariuszy instytucjonalnych z drugiej. Do tej drugiej kategorii zaliczono zarówno respondentów reprezentujących wydziały urzędów miast (stolic regionów), jak i innych interesariuszy, którzy są uczestnikami procesów przyciągania inwestorów, turystów czy studentów, takich jak: Regionalna Organizacja Turystyczna, Izba Przemysłowo-Handlowa czy uniwersytet.

Prowadzona równolegle analiza dyskursu strategicznego dotyczyła frekwencyjności występowania terminów związanych z miastem-stolicą województwa $\mathrm{w}$ dokumentach strategicznych i operacyjnych badanych województw. Przyjęto, że wysoka częstość występowania tych terminów będzie świadczyć o większym uznaniu roli stolicy województwa w procesach rozwoju gospodarczego regionu. Analizie poddano dokumenty, które powstawały w okresie 2010-2012, a następnie były przyjmowane przez sejmiki poszczególnych województw w latach 2013-2014. Zaobserwowany dyskurs pochodzi zatem z tego samego okresu, co zebrany materiał empiryczny w postaci wywiadów.

Podsumowując tę część rozważań, można stwierdzić, że badanie jest wielowątkowe. Jakościowe ujęcia, triangulacja danych, wielokrotne studia przypadków to działania, które mają prowadzić do lepszego zrozumienia złożonej rzeczywistości czy choćby jej fragmentu. 


\subsection{Podsumowanie}

W rozdziale wykazano celowość wykorzystania omawianej metody badawczej przy badaniu relacji międzyorganizacyjnych w sektorze publicznym. Zarówno niewielka liczebność próby w przypadku organizacji terytorialnych na szczeblu województwa, jak i specyfika badanych problemów uzasadnia prowadzenie badań metodą zbiorowego studium przypadku. Dodatkowo, za wyborem tej metody przemawia złożoność problematyki badawczej oraz możliwość pełniejszego eksplorowania interesujących problemów.

Metodzie tej towarzyszy nie statystyczny, jak w badaniach ilościowych, ale celowy dobór przypadków. Nakłada to na badacza obowiązek precyzyjnego określenia, jakich przypadków poszukuje, uwzględniając założenia teorii, w ramach której prowadzona będzie późniejsza analiza. Autor był świadomy, że od prawidłowego doboru przypadków zależy w dużym stopniu rezultat badania. Dodajmy, że w przypadku tej metody możliwość popełnienia błędów jest większa niż w przypadku badań ilościowych. Zwiększa to odpowiedzialność badacza za dobór próby do badań.

Warto jednocześnie zauważyć, że metoda zbiorowego studium przypadku, chociaż entuzjastycznie oceniana przez wielu autorów, posiada też pewne wady. Relatywnie niewielka liczba włączonych do analizy podmiotów badawczych ogranicza stosowanie złożonych metod statystycznych. Tym niemniej zastosowanie zbiorowego studium przypadku może zaowocować naprawdę nowymi wynikami, które mogą na trwałe wpisać się $\mathrm{w}$ dyskurs naukowy dotyczący relacji międzyorganizacyjnych organizacji terytorialnych. 



\section{Rozdział 5}

\section{Organizacja terytorialna i jej relacje $z$ interesariuszami instytucjonalnymi w kontekście prowadzenia polityki rozwoju - wyniki badań empirycznych}

Główne pytanie stawiane $\mathrm{w}$ tym rozdziale dotyczy uwarunkowań relacji partnerskich OT w kontekście realizowanej polityki rozwoju oraz tego, jakie grupy podmiotów można uznać za kluczowych partnerów w prowadzeniu polityki rozwoju województwa. Wspomniana polityka rozwoju jest ukierunkowana na podnoszenie konkurencyjności regionu, co skutkuje podnoszeniem zdolności do przyciągania zewnętrznych czynników wzrostu. Efektem tego etapu będzie zatem zidentyfikowanie kluczowych rynków interesariuszy dla organizacji terytorialnej na poziomie województwa, $\mathrm{z}$ którymi organizacja ta wchodzi $\mathrm{w}$ interakcje na poziomie operacyjnym z uwzględnieniem specyfiki relacji i typu interesariusza.

Autor bazuje na wynikach badań empirycznych, prowadzonych w postaci wywiadów kwestionariuszowych z respondentami reprezentującymi jednostki organizacyjne badanych OT oraz interesariuszy instytucjonalnych. Respondentami byli więc menedżerowie publiczni, kierujący jednostkami organizacyjnymi bezpośrednio lub pośrednio zaangażowanymi $\mathrm{w}$ realizację polityki rozwoju badanych województw oraz menedżerowie będący szefami interesariuszy instytucjonalnych. Kierując się perspektywą badań marketingu relacji, zaproponowaną przez szkołę amerykańską [Christopher et al. 2008, s. 6-9], szczególną uwagę przywiązywano do menedżerów publicznych jako do osób, które w zakresie kreowania nowych relacji międzyorganizacyjnych i zarządzania nimi odgrywają zasadniczą rolę. Metodyka tego badania przeprowadzonego w czterech wybranych polskich województwach została szczegółowo opisana w rozdziale czwartym. 
Wyniki badań powinny dostarczyć informacji na temat kluczowej roli OT na szczeblu regionu w zakresie kształtowania relacji międzyorganizacyjnych w procesie budowy konkurencyjności regionu. Autor przyjmuje założenie, że OT jest niejednorodna, jeżeli chodzi o jej zdolności oraz kompetencje relacyjne i że wyższe kompetencje w tym zakresie wykazują te jej jednostki organizacyjne (departamenty), których zadania są powiązane z podmiotami zewnętrznymi funkcjonującymi na rynku.

Dla zidentyfikowania i zweryfikowania istniejących między tymi jednostkami organizacyjnymi różnic dokonano ich podziału na trzy rodzaje: rynkowe (RYN), sektorowe (SEK) i administracyjne (ADM). Badania przeprowadzono techniką wywiadu strukturalizowanego z dyrektorami departamentów. Przeprowadzono łącznie 43 wywiady, w tym: 12 wywiadów (RYN), 18 wywiadów (SEK) oraz 13 wywiadów (ADM). Natomiast interesariuszy instytucjonalnych podzielono na cztery typy: TYP 1 - lokalne JST i ich związki (10 wywiadów), TYP 2 - administracja państwowa (10 wywiadów), TYP 3 - publiczne uczelnie wyższe (8 wywiadów) oraz TYP 4 - podmioty okołobiznesowe (14 wywiadów).

W niniejszym rozdziale opisano deklarowaną przez menedżerów publicznych otwartość OT na szczeblu regionu oraz zaprezentowano wyniki badania przeprowadzonego techniką ,tajemniczy klient” weryfikującego tę otwartość w określonym zakresie. Dokonano również charakterystyki czynników wpływających na intensywność i zakres współpracy pomiędzy badanymi urzędami marszałkowskimi i ich interesariuszami instytucjonalnymi, aby następnie skoncentrować się na relacji region-lokalne JST z perspektywy organizacyjnej. Eksploracja tej ostatniej relacji pozwoliła doprecyzować trzeci etap badań (opisany w rozdziale szóstym), gdzie skoncentrowano uwagę na, zdaniem autora kluczowej dla kształtowania skutecznej polityki rozwoju województwa, relacji: region-miasto (stolica regionu) w kontekście prowadzenia przez region działań marketingowych zorientowanych na pozyskiwanie mobilnych czynników wzrostu.

\subsection{Ocena otwartości organizacji terytorialnej i jej interesariuszy instytucjonalnych w opinii menedżerów}

Poniżej zaprezentujemy pierwszą część wyników badania z menedżerami zrealizowanego poprzez wywiady bezpośrednie prowadzone w siedzibach podmiotów, którymi kierują. 


\subsubsection{Otwartość organizacji terytorialnej (urzędu marszałkowskiego) $i$ jej interesariuszy instytucjonalnych w ocenie badanych menedżerów}

\section{Ocena otwartości organizacji terytorialnej}

Złożoność i wieloznaczność kategorii „otwartość organizacji terytorialnej” zdeterminowała kształt weryfikującego ją pytania (pytanie otwarte). Stworzyło to warunki do uzasadniania odpowiedzi udzielanych przez respondentów. Praktycznie wszyscy badani menedżerowie przyznali, że reprezentowana przez nich organizacja (urząd marszałkowski) jest: otwarta na wspólne przedsięwzięcia, projekty, działania, realizowane $z$ zewnętrznymi podmiotami na rzecz społeczności regionu. Aż $81 \%$ badanych wskazało na pełną otwartość urzędu, natomiast 19\% otwartość taką wiązało z pewnymi ograniczeniami. Nikt z respondentów nie zanegował otwartości urzędu marszałkowskiego jako organizacji pozostającej w relacjach z otoczeniem.

Biorąc pod uwagę dokonany wcześniej podział badanych jednostek na trzy rodzaje wykazano, że menedżerowie z departamentów administracyjnych $(\mathrm{ADM})$ relatywnie rzadziej wskazywali na pełną otwartość urzędu. Sytuację tę zilustrowano na rys. 5.1. Przywoływane uzasadnienia takich odpowiedzi sugerują, że otwartość urzędu marszałkowskiego jest ograniczana przepisami administracyjnymi. Natomiast w przypadku departamentów rynkowych i sektorowych otwartość ta została oceniona bardzo wysoko przez ponad $90 \%$ badanych.

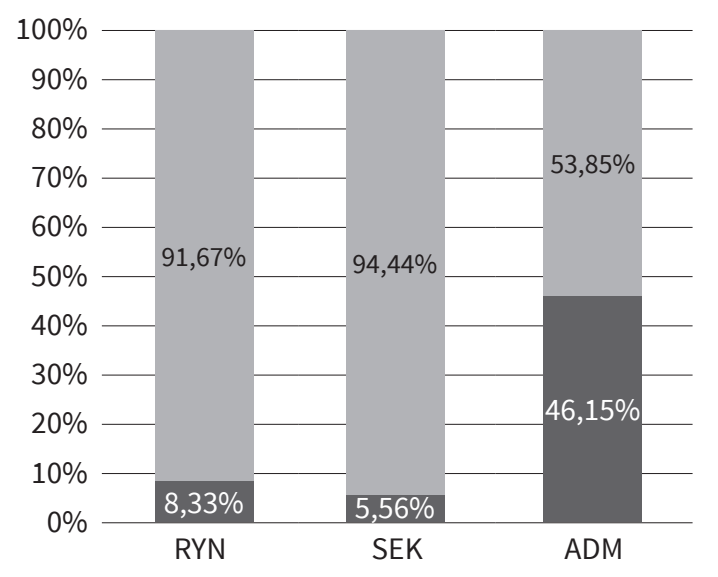

Tak, bardzo otwarty

Tak otwarty, ale (...)

Rys. 5.1. Otwartość zewnętrzna całego urzędu marszałkowskiego w ocenie menedżerów według rodzajów departamentów $(n=43)$

Rodzaj jednostek organizacyjnych: RYN - rynkowe, SEK - sektorowe, ADM - administracyjne.

Źródło: badania własne. 
Badani mieli również ocenić rolę współpracy zewnętrznej w działalności kierowanego przez siebie departamentu. Odnotowano tu istotne różnice $\mathrm{w}$ odpowiedziach osób $\mathrm{z}$ poszczególnych rodzajów departamentów. Respondenci z departamentów rynkowych wskazali niemal jednomyślnie na kluczową rolę współpracy z podmiotami zewnętrznymi w ich działalności (92\%). Menedżerowie z departamentów „sektorowych" ocenili taką współpracę jako bardzo ważną w $67 \%$. Natomiast przedstawiciele departamentów administracyjnych uznali taką współpracę za bardzo ważną zaledwie w około $30 \%$. Wyniki zaprezentowano na rys. 5.2.

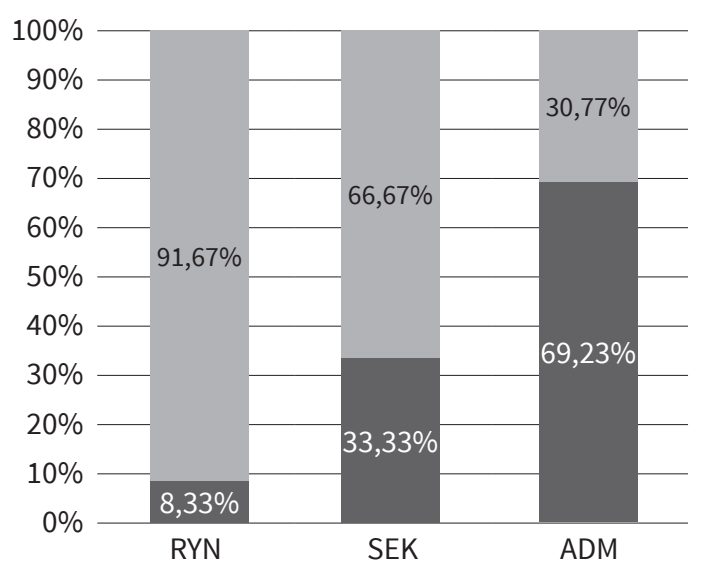

Bardzo istotna rola

Niedoprecyzowana rola

Rys. 5.2. Rola współpracy zewnętrznej w ocenie menedżerów według rodzajów departamentów $(\mathrm{n}=43)$

Rodzaj jednostek organizacyjnych: RYN - rynkowe, SEK - sektorowe, ADM - administracyjne.

Źródto: jak do rys. 5.1.

Respondenci mieli również możliwość dokonania oceny współpracy między departamentami w obrębie danego urzędu marszałkowskiego. Zdecydowana większość badanych oceniła ją jako dobrąśrednią. Jest to więc ocena wyraźnie słabsza od prezentowanej wcześniej współpracy zewnętrznej, gdzie dominowały oceny bardzo wysokie. Oceny takie pozwalają przypuszczać, że respondenci dają w ten sposób wyraz swojego niezadowolenia $\mathrm{z}$ jakości współpracy wewnętrznej. W grupie menedżerów z departamentów rynkowych i sektorowych zaledwie $17 \%$ oceniło współpracę wewnętrzną w urzędzie jako bardzo dobrą. Ocena taka, w przypadku departamentów administracyjnych, była wyższa i kształtowała się na poziomie 38\%. Można to wyjaśnić w ten sposób, że są to jed- 
nostki, których działalność polega właśnie na współpracy z pozostałymi jednostkami organizacyjnymi urzędu. Ocenę współpracy wewnętrznej przedstawiono na rys. 5.3.

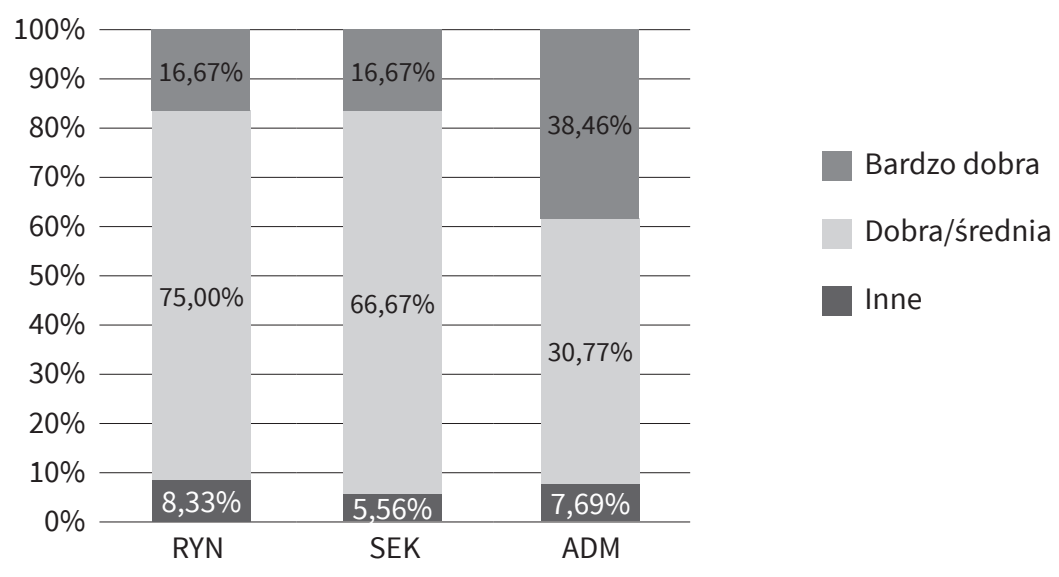

Rys. 5.3. Współpraca wewnętrzna w urzędzie marszałkowskim w ocenie menedżerów według rodzajów departamentów $(n=43)$

Rodzaj jednostek organizacyjnych: RYN - rynkowe, SEK - sektorowe, ADM - administracyjne.

Źródło: jak do rys. 5.1.

Respondenci zostali również poproszeni o odniesienie się do stwierdzenia: Wspólne działania przynoszą lepsze efekty, co miało pokazać ich postawy kooperacyjne. Stwierdzenie to spotkało się z wysoką aprobatą respondentów. Blisko 54\% badanych „całkowicie się zgodziło" z tym stwierdzeniem, a 44\% wskazało odpowiedź „zgadzam się”. Pozostałe kategorie odpowiedzi wystąpiły sporadycznie. Można jednak odnotować, że w grupie kobiet $2 / 3$ zaznaczyło pierwszą odpowiedź, zaś 1/3 - drugą, podczas gdy odpowiedzi mężczyzn rozłożyły się po równo. Można to zinterpretować w ten sposób, że kobiety bardziej niż mężczyźni wykazują postawy kooperacyjne. Próbowano również określić postawy kooperacyjne menedżerów według wieku. Okazało się, że im starszy menedżer, co w domyśle znaczy - bardziej doświadczony, tym bardziej zdecydowanie opowiada się za współpracą.

\section{Ocena otwartości interesariuszy instytucjonalnych}

Badania dotyczyły również otwartości interesariuszy instytucjonalnych organizacji terytorialnej na współpracę. Respondenci byli pytani o zakres otwartości kierowanych przez nich organizacji. Większość z nich zade- 
klarowało wysoką otwartość, chociaż uwzględniając dokonany wcześniej podział na typy organizacji, można zaobserwować pewne różnice w odpowiedziach. Jako najbardziej otwarte okazały się uczelnie wyższe (100\% wskazań) oraz lokalne JST (90\%). Respondenci z pozostałych typów badanych organizacji deklarowali otwartość na poziomie 80\% (administracja państwowa) oraz 78\% (organizacje okołobiznesowe). Szczegółowe wyniki umieszczono na rys. 5.4.

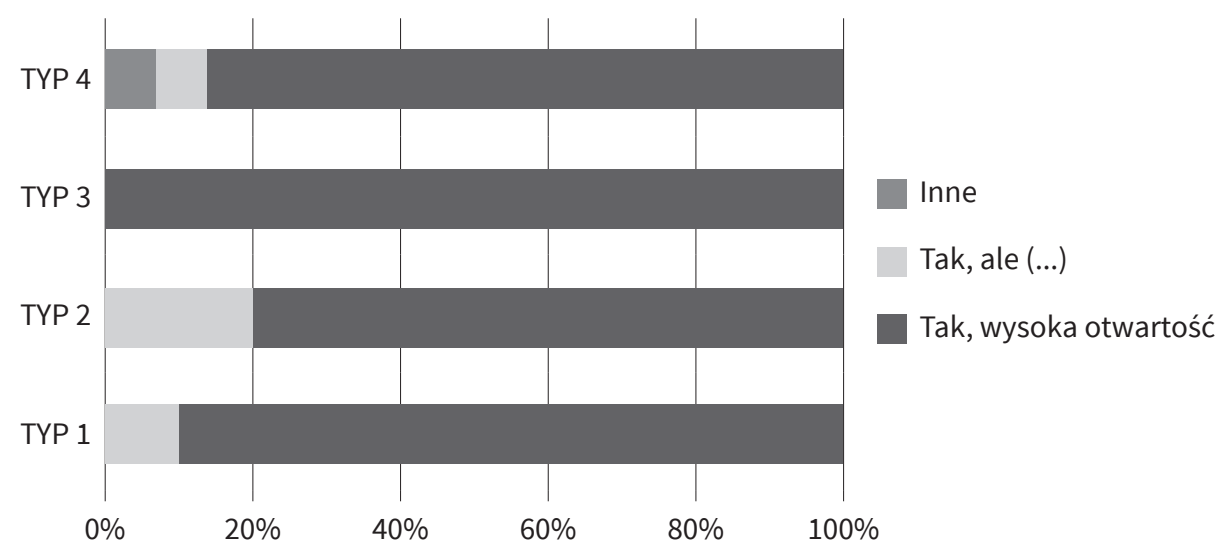

Rys. 5.4. Ocena otwartości zewnętrznej interesariuszy instytucjonalnych $(n=42)$

Typy badanych podmiotów: TYP 1 - lokalne JST, TYP 2 - administracja państwowa, TYP 3 - uczelnie wyższe, TYP 4 - organizacje okołobiznesowe.

Źródto: jak do rys. 5.1.

Można było oczekiwać, że prezentowana na rys. 5.4 otwartość zewnętrzna interesariuszy instytucjonalnych pozostaje w ścisłym związku z rolą współpracy zewnętrznej w realizacji celów tych interesariuszy. Badania nie do końca potwierdzają taką zależność. Co prawda największa zgodność występuje w przypadku uczelni wyższych, gdzie na taką rolę wskazuje blisko $90 \%$ respondentów, ale inaczej to wygląda w przypadku menedżerów z innych typów badanych interesariuszy. Szczególnie duże różnice można dostrzec $\mathrm{w}$ przypadku lokalnych JST, gdzie otwartość deklarowało 90\% respondentów, zaś rolę współpracy w realizacji celów określono jedynie na poziomie $60 \%$. Rola taka jest stosunkowo wysoka w przypadku administracji państwowej (80\%) i nieco niższa w przypadku organizacji okołobiznesowych (72\%). Dodajmy, że respondenci ze wszystkich typów interesariuszy deklarują swój wysoki udział w partnerstwie $\mathrm{z}$ organizacją terytorialną, przy czym uczelnie wyższe deklarują to w $100 \%$, zaś pozostałe w $70 \%$. 
Przyjrzyjmy się obecnie uwarunkowaniom partnerstwa $\mathrm{z}$ pozycji poszczególnych typów interesariuszy instytucjonalnych. W ocenie respondentów reprezentowane przez nich organizacje w zdecydowanej większości są strategicznym partnerem dla samorządu regionu (suma odpowiedzi „całkowicie się zgadzam” i „zgadzam się”). Przy czym przedstawiciele uczelni wyższych $\mathrm{w} 100 \%$ widzą siebie $\mathrm{w}$ takiej roli, podczas gdy administracja państwowa i lokalne JST w 90\%. Nieco inaczej jest w przypadku organizacji okołobiznesowych, gdzie przeważają co prawda odpowiedzi pozytywne (blisko 55\%), ale jest również wiele odpowiedzi negatywnych (blisko 30\%).

Respondenci ze wszystkich typów interesariuszy niemal w 100\% uznali swoje organizacje za niezbędne w efektywnej realizacji polityki rozwoju województwa. Wskazali jednocześnie, że misja i cele ich instytucji nie do końca wpisują się w kierunki rozwoju województwa nakreślone w jego strategii rozwoju. Na zbieżność celów wskazali przede wszystkim przedstawiciele uczelni wyższych (100\% odpowiedzi „całkowicie się zgadzam” i „zgadzam się"). Stosunkowo wysoka zbieżność wystąpiła również w przypadku lokalnych JST (80\%) oraz instytucji okołobiznesowych (64\%). Zbieżność ta była mniejsza w przypadku administracji państwowej (50\%) i ma to prawdopodobnie związek z faktem, że sprawuje ona funkcje kontrolne wobec samorządów terytorialnych i w tym kontekście nie ma pełnej spójności w zakresie celów stawianych obu strukturom. $\mathrm{W}$ przypadku respondentów $\mathrm{z}$ ministerstw ograniczoną zbieżność można wyjaśnić w ten sposób, że reprezentują oni perspektywę całego kraju.

Z badań wynika, że na współpracę operacyjną interesariuszy instytucjonalnych $\mathrm{z}$ samorządem regionu w ograniczonym zakresie wpływają układy polityczne. Zarówno uczelnie wyższe, jak i lokalne JST w ogóle nie dostrzegają takiego wpływu (chyba że zawiera się on w odpowiedziach ",trudno powiedzieć). Zauważają go natomiast organizacje okołobiznesowe (43\%) oraz administracja państwowa (30\%). Respondenci nie zgodzili się generalnie ze stwierdzeniem, że samorząd regionu posiada za mało swobody w prowadzeniu polityki rozwoju województwa. Jedynie organizacje okołobiznesowe zgodziły się z tym stwierdzeniem na poziomie 37\% (łącznie „całkowicie się zgadzam” i „zgadzam się"). Respondenci z pozostałych typów interesariuszy deklarowali zgodność zaledwie na poziomie $20 \%$ lub mniej.

W dalszych rozważaniach przedstawimy opinie poszczególnych typów interesariuszy na temat partnerstwa. Praktycznie wszyscy respondenci zgodzili się ze stwierdzeniem, że wspólne działania przynosza lepsze efekty. Nie zgodzili się jednocześnie, że wchodzenie w związki partnerskie może stanowić zagrożenie dla ich organizacji oraz z tym, że partnerstwo to tylko teoria, że $w$ praktyce jest ono niemożliwe. Jedynie kilkanaście procent przedstawicieli organizacji okołobiznesowych było 
innego zdania. W zasadzie nie zgodzili się też, że partnerstwo w działalności ich organizacji jest całkowicie zdeterminowane przez przepisy funduszy unijnych. Pomijając szkoły wyższe, gdzie nie było przeciwnych odpowiedzi, ich udział nie przekraczał 10-20\%. Bardziej zróżnicowane opinie dotyczyły kluczowego w tym przypadku stwierdzenia, czy partnerstwo zdecyduje o pozycji instytucji w przyszłości. Najczęściej zgadzali się z nim respondenci z uczelni wyższych (blisko $90 \%$ odpowiedzi „całkowicie się zgadzam” i „zgadzam się"). W ponad $60 \%$ były co do tego zgodne lokalne JST oraz organizacje okołobiznesowe. Najrzadziej zgadzali się z tym stwierdzeniem (30\%) przedstawiciele administracji państwowej, co wydaje się zrozumiałe ze względu na usytuowanie tego typu interesariuszy.

Reasumując tę część rozważań, można stwierdzić, że menedżerowie publiczni deklarują otwartość na współpracę zewnętrzną. Pewne różnice $\mathrm{w}$ tych deklaracjach mają związek $\mathrm{z}$ charakterem poszczególnych departamentów, z których część jest bardziej ukierunkowana na taką współpracę. Menedżerowie jednostek rynkowych wykazują relatywnie większą otwartość na współpracę niż jednostek administracyjnych. Częściej też deklarują współpracę z podmiotami niepublicznymi niż z publicznymi.

Zróżnicowana jest także rola takiej współpracy w realizacji celów poszczególnych rodzajów departamentów. Nieprzypadkowo jest ona największa w przypadku tzw. departamentów rynkowych. Pewnym zaskoczeniem może być natomiast dokonana przez nich niezbyt korzystna ocena współpracy wewnętrznej. Generalnie respondenci oceniają taką współpracę jako dobrą/średnią, co może oznaczać słabą koordynację procesów zorientowanych na zewnątrz w samym urzędzie. Może to wpływać na pozycję OT oraz na jej postrzeganie przez zewnętrznych interesariuszy.

Szeroki zakres otwartości na współpracę deklarują również interesariusze instytucjonalni OT, przy czym największą - uczelnie wyższe oraz lokalne JST. Nie zawsze jednak deklaracja otwartości jest zgodna z rolą współpracy zewnętrznej w realizacji celów tych interesariuszy. Największa zgodność występuje w przypadku uczelni wyższych, najmniejsza zaś w przypadku lokalnych JST (90\% do 60\%). Na podkreślenie zasługuje fakt, że interesariusze instytucjonalni mają świadomość swojej wysokiej pozycji jako partnerów dla urzędu marszałkowskiego, a także swojej kluczowej roli w efektywnej realizacji polityki rozwoju województwa. W wyrażanych przez nich opiniach układy polityczne nie mają praktycznie wpływu na relacje partnerskie realizowane na poziomie operacyjnym. Zgodne są również ich opinie na temat korzyści, jakie przynosi współpraca oraz tego, że partnerstwo zdecyduje o ich pozycji w przyszłości. 


\subsubsection{Identyfikacja partnerów do współpracy dla organizacji terytorialnej na szczeblu regionu}

W badaniu dokonano podziału partnerów do współpracy z urzędem marszałkowskim na dwie grupy - partnerów publicznych i niepublicznych. W pierwszej grupie znalazły się organizacje państwowe i samorządowe, natomiast w drugiej - organizacje prywatne i społeczne. Podjęto próbę określenia, z którymi rodzajami partnerów budują swoje relacje poszczególne jednostki organizacyjne urzędu marszałkowskiego i jakie konkretnie są to podmioty. Poszczególne rodzaje partnerów publicznych i ich znaczenie dla poszczególnych rodzajów departamentów organizacji terytorialnej zaprezentowano na rys. 5.5.

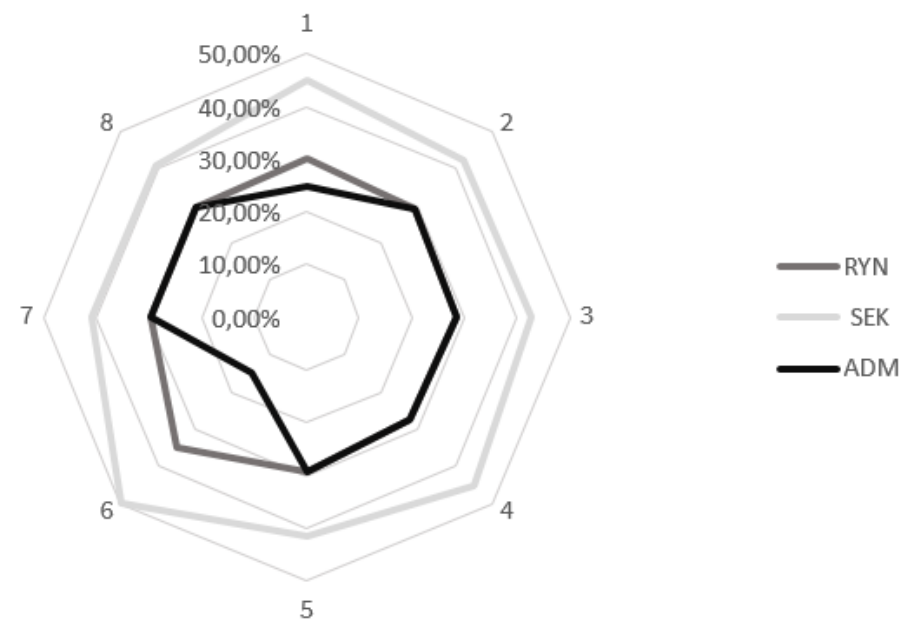

Rys. 5.5. Identyfikacja partnerów publicznych dla jednostek organizacji terytorialnej $(n=43)$

Rodzaj jednostek organizacyjnych: RYN - rynkowe, SEK - sektorowe, ADM - administracyjne; 1. JST z obszaru województwa i ich związki; 2. Wojewoda i jego służby; 3. Administracja rządowa (ministerstwa, agencje rządowe); 4. Samorządy innych województw w Polsce; 5. Publiczne szkoły wyższe; 6. Publiczne ośrodki naukowo-badawcze; 7. Organizacje międzynarodowe;

8. Regiony innych państw.

Źródto: jak do rys. 5.1.

Najwięcej menedżerów z departamentów sektorowych zadeklarowało utrzymywanie relacji z partnerami publicznymi. W zależności od rodzaju podmiotu publicznego było to: od $41 \% \mathrm{w}$ przypadku wskazania organizacji międzynarodowych, do 50\% w przypadku ośrodków naukowo-badawczych. Natomiast menedżerowie z departamentów rynkowych 
w odniesieniu do wszystkich typów organizacji publicznych wskazywali relatywnie mniej partnerów od menedżerów departamentów sektorowych. Można stąd wyciągnąć wniosek, że departamenty sektorowe, w szerszym zakresie niż rynkowe, budują relacje z organizacjami publicznymi. Są to też relacje bardziej sformalizowane, bazujące na aktach normatywnych, gdzie procedura podejmowania i prowadzenia relacji jest ściśle określona. Menedżerowie z departamentów rynkowych utrzymywali relacje z takimi podmiotami publicznymi, jak: JST z obszaru województwa i ich związki, centralna administracja rządowa oraz publiczne szkoły wyższe. Tylko nieco rzadziej wskazywali na istniejące relacje z wojewodą i jego służbami oraz samorządami innych województw w Polsce.

Natomiast menedżerowie departamentów administracyjnych deklarowali dużo mniej relacji z podmiotami zewnętrznymi, co mogło mieć związek z ich ograniczoną otwartością, ze względu na wewnętrzną orientację tych jednostek. Podmioty, z którymi menedżerowie z tych departamentów deklarowali utrzymywanie relacji, to: organizacje międzynarodowe i regiony innych państw (po 30\% respondentów). Otwarty charakter pytania pozwolił na pozyskanie obok konkretnych odpowiedzi również ich interpretacji. Okazało się, że zewnętrzna współpraca z równorzędnymi podmiotami z zagranicy (urzędami regionalnymi) często dotyczy usprawniania funkcjonowania wewnętrznych struktur urzędów, co miało miejsce właśnie w przypadku departamentów administracyjnych.

Organizacje niepubliczne były rzadziej niż publiczne wskazywane jako partnerzy jednostek organizacyjnych urzędów marszałkowskich, chociaż ich liczba jest dużo wyższa niż podmiotów publicznych funkcjonujących na danym terytorium. Interesująca jest natomiast analiza wyników szczegółowych. Różnice pomiędzy poszczególnymi rodzajami jednostek organizacyjnych urzędu zaprezentowano na rys. 5.6. Organizacje niepubliczne jako potencjalni partnerzy były wskazywane znacznie częściej przez menedżerów z departamentów rynkowych i sektorowych niż z departamentów administracyjnych.

W przypadku departamentów rynkowych respondenci najczęściej wskazywali na następujące kategorie podmiotów niepublicznych: prywatne ośrodki naukowo-badawcze (55\%), prywatne szkoły wyższe (43\%) oraz samorząd gospodarczy (38\%). Wskazania te są więc częstsze niż wobec organizacji publicznych. Prowadzi to do wniosku, że departamenty rynkowe są bardziej zorientowane na relacje z podmiotami społecznymi i prywatnymi niż publicznymi. Stosunkowo rzadko wskazywano zaś na relacje z indywidualnymi przedsiębiorstwami (27\%) i samorządami zawodowymi (26\%).

W przypadku departamentów sektorowych relatywnie często wskazywano takie podmioty do współpracy, jak: samorząd zawodowy (52\%), indywidualne przedsiębiorstwa (45\%) i organizacje pozarządowe (38\%). 
Natomiast ponad 70\% badanych z departamentów administracyjnych nie wskazało żadnych partnerów pozarządowych, co jasno pokazuje, że ich relacje ze środowiskiem zewnętrznym są bardzo ograniczone.

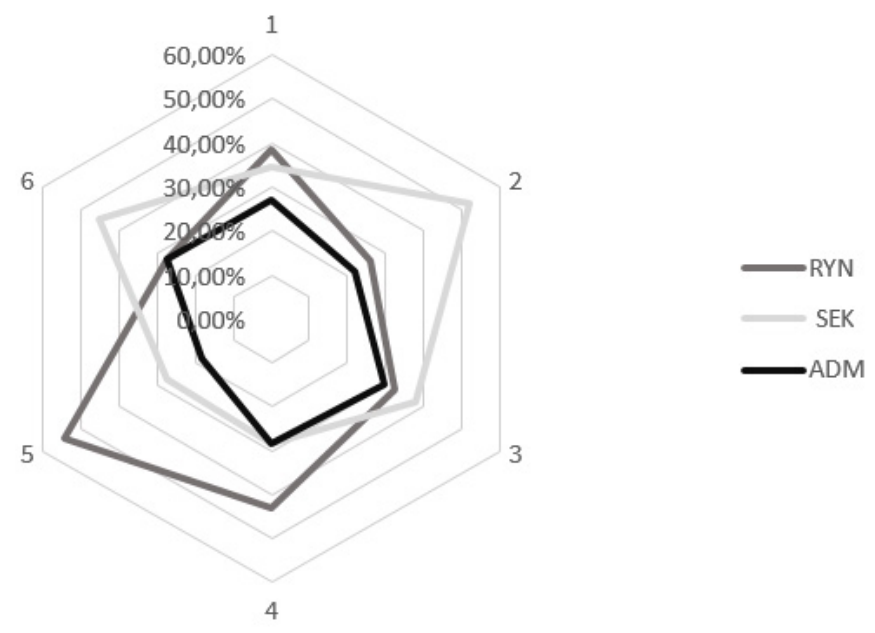

Rys. 5.6. Identyfikacja partnerów niepublicznych dla organizacji terytorialnej $(n=43)$

Rodzaj jednostek organizacyjnych: RYN - rynkowe, SEK - sektorowe, ADM - administracyjne; 1. Samorząd gospodarczy; 2. Samorząd zawodowy; 3 . Organizacje pozarządowe; 4. Prywatne szkoły wyższe; 5. Prywatne ośrodki naukowo-badawcze; 6. Indywidualne przedsiębiorstwa.

Źródło: jak do rys. 5.1.

Podsumowując należy zaznaczyć, że partnerzy publiczni byli najczęściej wskazywani przez menedżerów z departamentów sektorowych i to w odniesieniu do wszystkich kategorii, natomiast partnerzy prywatni - przez menedżerów z departamentów rynkowych. Wskazywali oni prywatne ośrodki naukowo-badawcze, prywatne szkoły wyższe oraz samorząd gospodarczy. Mniej wskazań partnerów, szczególnie tych niepublicznych, odnotowano w przypadku menedżerów z departamentów organizacyjnych.

\subsubsection{Badanie otwartości organizacji terytorialnej metodą „tajemniczy klient” (mystery client)}

Chcąc ocenić rzeczywistą, a nie tylko deklarowaną, otwartość badanych urzędów marszałkowskich, podjęto badanie metodą „tajemniczy klient”. Skierowano do badanych OT zapytanie o informację publiczną. Pisma 
w języku angielskim zostały wysłane do wszystkich czterech badanych urzędów marszałkowskich na początku miesiąca czerwca, na adresy mailowe marszałków województw. W badaniu tym oceniano sposób udzielania odpowiedzi, jej szybkość, formę, treść, pracę osoby odpisującej itp. Warto podkreślić, że treść pytań kierowanych do urzędu marszałkowskiego została tak dobrana, aby jej odpowiedzi musiały być przygotowane przez przynajmniej dwie jednostki organizacyjne, które według powyższej nomenklatury należy nazwać jako rynkowe (RYN). Metodyka tego badania została szczegółowo opisana w rozdziale czwartym.

$\mathrm{W}$ procesie badawczym uzyskano odpowiedzi od zaledwie 2 organizacji terytorialnych, zaś 2 pozostałe nie odpowiedziały mimo powtórnego kierowania zapytań o informację publiczną. $\mathrm{W}$ terminie 14 dni odpowiedzi udzielił zaledwie jeden urząd marszałkowski. Termin 14-dniowy wynika z ustawy BIP, który dotyczy prośby o informację publiczną, a właśnie tak zostało oznaczone przez nadawcę pismo (mail). Jeżeli jednak urząd nie zakwalifikował tej korespondencji jako prośbę o informację publiczną, ale jako sprawę administracyjną, to termin odpowiedzi podlegał regulacjom Kodeksu Postępowania Administracyjnego, które wskazują na obowiązkowy, 30-dniowy okres udzielenia odpowiedzi. Dlatego po upływie $30 \mathrm{dni}$ respondenci otrzymali ponownego maila przypominającego wcześniejsze zapytanie. Badanie trwało 90 dni. W ciągu tego okresu odpowiedziały dwa spośród czterech urzędów (małopolskie - udzielono dwóch niezależnych odpowiedzi oraz po ponagleniu, łódzkie - jedna odpowiedź) ${ }^{1}$.

Oznacza to, że z urzędów - wielkopolskiego i świętokrzyskiego nie wpłynęły odpowiedzi. Jest to tym bardziej niepokojące, że zapytania wysłane zostały na adresy mailowe marszałków lub ich bezpośredniego zaplecza (kancelaria marszałka), czyli tzw. centrów dowodzenia OT. Brak jakiejkolwiek reakcji po dwóch wysłanych zapytaniach może świadczyć o tym, że deklarowana przez urzędy marszałkowskie otwartość, jest w dużej mierze pozorna. Nie zastosowano się do obowiązku udzielenia odpowiedzi ani nie podjęto żadnych działań skutkujących reakcją na zewnętrz.

Interesująca jest odpowiedź która napłynęła 78 dni po wysłaniu zapytania. W jej treści znajdowało się wyjaśnienie przyczyny opóźnienia (okres wakacyjny) oraz starannie przygotowana odpowiedź. Zastanawiające jest zatem spowolnienie działalności urzędu, wynikające $\mathrm{z}$ okresu wakacyjnego. Zwykle przepisy wewnętrzne, a na pewno uwarunkowania

1 Warto nawiązać do innego prowadzonego tą metodą badania, wspótrealizowanego przez autora w odniesieniu do 8 polskich miast, gdzie odpowiedzi na zapytanie udzielity w przeciągu 30 dni zaledwie 3 miasta, a po ponagleniu (w ciągu następnych 30 dni) 2 kolejne. Oznacza to, że pozostałe 3 miasta w ogóle nie udzielity odpowiedzi [Anders-Morawska, Rudolf 2015, s. 207-209]. 
zwyczajowe, nie pozwalają pracownikom na branie urlopów dłuższych jednorazowo niż 2-3 tygodnie. Zawsze ustanawia się też urzędowe zastępstwo w prowadzonych sprawach i projektach. Należy jednak podkreślić, że odpowiedź ta miała typowo administracyjny charakter. Odpowiadający nie próbował dowiedzieć się czegoś więcej o organizacji, która sformułowała zapytanie, nie starał się nawiązać z nią relacji.

Jakość merytoryczna udzielonych odpowiedzi jest satysfakcjonująca. Są one w pełni zgodne $\mathrm{z}$ intencją pytającego, rzetelne, trafne, odnoszą się kolejno do zadanych pytań. Zakończenia są natomiast zróżnicowane. Właściwie każde pismo kończy się innym zwrotem: Yours sincerelly (małopolskie 2), Do not hesitate to contact me if you require any further information or precision about the answers (małopolskie 1), Sorry for any inconvenience (łódzkie).

Na uwagę zasługuje dość zaskakujące, jak na administrację publiczną, zachowanie przedstawiciela jednego z urzędów (małopolska 1), który już na drugi dzień po wysłaniu zapytania odpisał w formie e-mailowej, kierując do pytającego prośbę o bliższe wyjaśnienia. Odpowiedzi na nią zostały udzielone jeszcze tego samego dnia. W związku z faktem, że w przypadku urzędu oznaczonego symbolem „małopolska 1” odpowiedź została przygotowana szybko oraz że charakteryzuje się on wysokim poziomem merytorycznym, a także uprzejmą formą i poprawnym angielskim, można przyjąć, że jest to zachowanie pożądane z perspektywy pytającego (potencjalnego partnera OT). Fakt ten sprawił, że w ramach badania podjęto działania zmierzające do ustalenia osoby, która udzieliła odpowiedzi na pytania i stała się tym samym tzw. pierwszym kontaktem. Interesujące jest to, że zapytanie skierowane pierwotnie do siedziby urzędu marszałkowskiego zostało przekazane do brukselskiego biura tego województwa. Przemawiać za tym mogą dwie kwestie. Instytucja pytająca ma siedzibę właśnie w Brukseli (w dzielnicy europejskiej), czyli bliskość geograficzna, a po drugie brukselskie biuro ma w swoich zadaniach budowanie relacji z podmiotami zagranicznymi. Pod mailem od "małopolska 1” podpisała się osoba o zagranicznym nazwisku.

$\mathrm{Na}$ podstawie informacji zaczerpniętych ze stron www, jak i dwóch rozmów przeprowadzonych $\mathrm{z}$ osobami reprezentującymi polskie środowiska samorządowe, które w okresie badania rezydowały w Brukseli, ustalono, że wspomniana osoba jest Europejką o polskich korzeniach. Na stałe mieszka w Wielkiej Brytanii. Biegle posługuje się językiem francuskim, angielskim oraz polskim. Studiowała w Dublinie, Glasgow oraz, w okresie badania, w Polsce. Posiadała doświadczenia zawodowe, wśród których był staż w brukselskim biurze województwa. Z informacji tych wynika, że jest osobą związaną ze środowiskiem międzynarodowym, ukształtowaną w kulturze brytyjskiej, o otwartym spojrzeniu na świat 
i szerokich horyzontach. Przypadek ten dowodzi, że sprawne działanie zależy od ludzi i ich postawy wobec realizowanych zadań. Wyrażona przez nią w pierwszym piśmie prośba o dodatkowe informacje wskazuje, że osoba ta wykazała się postawą otwartą, zainteresowaną korzyściami dla OT z wejścia w relacje z podmiotem pytającym.

Powyższe stwierdzenia prowadzą do wniosku, że pracownicy urzędów marszałkowskich prowadzący korespondencję zagraniczną nie zawsze są przygotowani do realizacji tego rodzaju zadań. Nie stosują obowiązujących standardów międzynarodowych, a z perspektywy prawnej nie stosują się do obowiązujących przepisów. W tego typu korespondencji uprzejme zaproszenie do dalszych kontaktów jest oczywistością i kreuje pozytywny obraz organizacji. Właściwie tylko w jednym przypadku („małopolska 1”) zastosowane sformułowanie wypełniało standardy.

Podsumowując wątek badawczy „tajemniczy klient”, można sformułować kilka wniosków. Pierwszy to taki, że w budowaniu relacji międzyorganizacyjnych najważniejsi są ludzie. Należy tu podkreślić, że tylko jedna odpowiedź, sformułowana przez „stażystkę", spełniała wysokie międzynarodowe standardy prowadzenia relacji. Kolejnym jest taki, że w przypadku menedżerów publicznych może istnieć spory dysonans pomiędzy tym, co deklarują (postawy kooperacyjne) a tym, jaka jest praktyczna urzędowa rzeczywistość. Można to wytłumaczyć w ten sposób, że odpowiedzi na kierowane do urzędu zapytania przygotowują pracownicy liniowi, niekiedy bez odpowiednich kompetencji czy odpowiedniej motywacji do prowadzenia relacji w środowisku międzynarodowym. Przykład pokazuje, że łamane są przepisy wynikające $\mathrm{z}$ krajowych regulacji i międzynarodowych standardów dotyczących prowadzonej korespondencji.

\subsection{Czynniki wpływające na współpracę zewnętrzną organizacji terytorialnej}

Kolejny wątek badania dotyczył stymulatorów i destymulatorów współpracy. Badani menedżerowie zostali poproszeni o wskazanie czynników, które skłaniają ich, jako dyrektorów departamentów urzędów marszałkowskich, do współpracy z organizacjami zewnętrznymi (niezależnie od podziału na organizacje publiczne i niepubliczne). Na podstawie badania pilotażowego zaproponowano listę 9 możliwych odpowiedzi oraz uwzględniono możliwość dopisania innych czynników (pozycja 10). Pytani byli również o napotykane przeszkody bądź utrudnienia w takiej współpracy. 


\subsubsection{Czynniki skłaniające do współpracy i utrudniające wspótpracę}

Czynniki skłaniające do współpracy oraz utrudniające współpracę będziemy analizować z pozycji obu stron relacji, a więc zarówno z pozycji menedżerów urzędu marszałkowskiego, jak i interesariuszy instytucjonalnych. Analizę rozpoczniemy od prezentacji opinii menedżerów publicznych.

Wśród udzielonych przez menedżerów z badanych OT odpowiedzi na pytanie o czynniki skłaniające do współpracy, zdecydowanie najwięcej wskazań dotyczyło oczekiwanych korzyści. Wymieniano tu najczęściej takie czynniki, jak: większe możliwości realizacji postawionych przed samorząem zadań (28\%) czy: chęć skorzystania z doświadczenia, wiedzy, kompetencji innych podmiotów (24\%). Wśród odpowiedzi nawiązujących do korzyści znalazła się również: chęć pozyskania zewnętrznych środków (12\%). Respondenci rzadziej wymieniali czynniki dotyczące przepisów prawno-administracyjnych, które mają nakłaniać kierowane przez nich jednostki organizacyjne do budowania relacji zewnętrznych. Odpowiedzi nawiązujące do przepisów krajowych i europejskich zostały jednakowo ocenione przez respondentów na poziomie $11 \%$. Wpływ otoczenia podmiotowego - w postaci takich czynników, jak: presja podmiotów z regionu, presja ze strony członków zarządu, moda na współdziałanie - wymieniano tylko sporadycznie.

Powyższe wyniki świadczą o świadomej postawie badanych menedżerów wobec roli partnerstwa $\mathrm{z}$ podmiotami zewnętrznymi. Akcentowali oni głównie wymierne korzyści ze współdziałania, rzadko wskazując na takie stymulatory partnerskich zachowań, jak presja przepisów czy presja innych podmiotów. Niżej podjęta zostanie próba zróżnicowania tych odpowiedzi z uwzględnieniem rodzaju departamentu respondenta i odnalezienia pewnych prawidłowości z tym związanych. Rezultaty zaprezentowano na rys. 5.7.

Warto zauważyć, że w grupie menedżerów z departamentów rynkowych najwięcej wskazań uzyskał czynnik: większe możliwości realizacji postawionych przed samorzadem zadań (44\%). Ten sam czynnik uzyskał również najwięcej wskazań w grupie menedżerów z departamentów sektorowych $(28 \%)$. Warto jednak podkreślić, że w grupie tej odpowiedzi są bardzo rozproszone. Z powodu różnorodności zadań departamentów sektorowych takie zróżnicowanie należy uznać za naturalne, adekwatne do istniejącej sytuacji. Interesujące jest również to, że w grupie menedżerów z departamentów administracyjnych najczęstszą odpowiedzią była: chęć skorzystania $z$ doświadczenia, wiedzy, kompetencji innych podmiotów (31\%). 


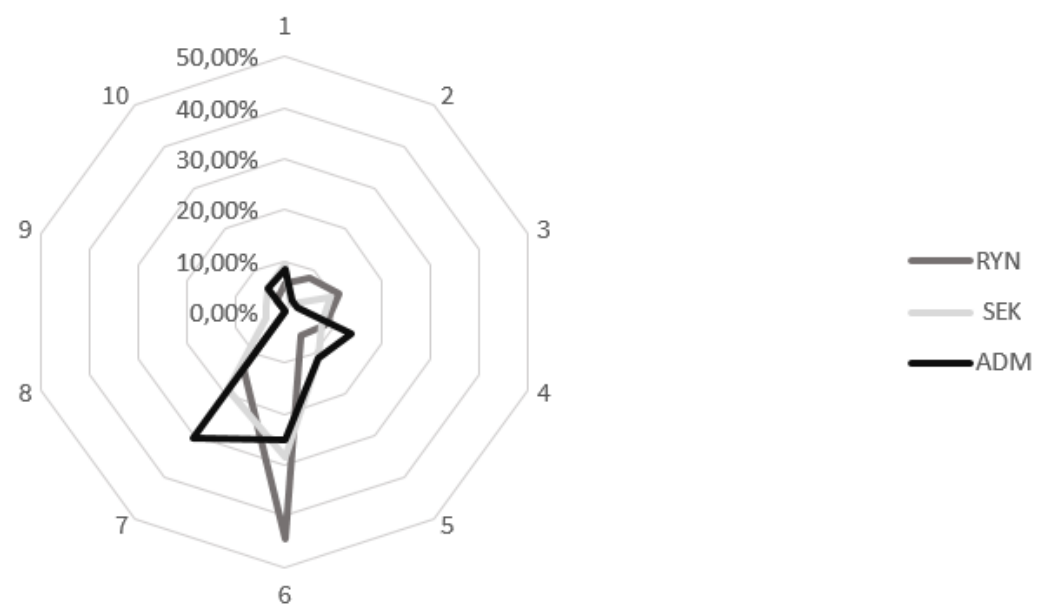

Rys. 5.7. Czynniki skłaniające do współpracy w opinii menedżerów publicznych $(n=43)$

Rodzaj jednostek organizacyjnych: RYN - rynkowe, SEK - sektorowe, ADM - administracyjne; 1. Presja podmiotów publicznych z regionu chcących współdziałać (potencjalni partnerzy sami zabiegają u dyrekcji departamentu o wspólne przedsięwzięcia); 2. Presja na departament ze strony członków zarządu województwa, aby nawiązywać szersze kontakty z potencjalnymi partnerami; 3. Obowiązek współdziałania wynikający z przepisów krajowych (ustawa o samorządzie województwa, art. 12.1); 4. Zasada partnerstwa wynikająca z przepisów europejskich (Rozporządzenie 1083/06); 5. Chęć pozyskania zewnętrznych środków; 6. Większe możliwości realizacji postawionych przed samorządem zadań; 7. Chęć skorzystania z doświadczenia, wiedzy, kompetencji innych podmiotów; 8. Czynnik lokalnej polityki (współpracując z innymi, zyskujemy wyborców); 9. Pewna moda na „współdziałanie” wynikająca z ogólnego stylu działań JST; 10. Inne czynniki, jakie? (proszę wpisać).

Źródło: jak do rys. 5.1 .

Menedżerowie badanych OT zostali następnie poproszeni o wskazanie czynników, które utrudniają im, jako dyrektorom departamentów urzędów marszałkowskich, współpracę z organizacjami zewnętrznymi (niezależnie od podziału na organizacje publiczne i niepubliczne). $\mathrm{Na}$ podstawie badania pilotażowego zaproponowano listę 10 możliwych odpowiedzi oraz możliwość dopisania innych czynników (pozycja 11).

Potwierdziła się prawidłowość, że respondenci szukają utrudnień czy negatywnych zjawisk nie na własnym podwórku, ale w otoczeniu, czyli u potencjalnych partnerów lub w przepisach prawa. Najczęściej pojawiające się odpowiedzi to: roszczeniowa postawa partnerów (26 wskazań), przepisy prawne ograniczające wspótprace (24) oraz ograniczenia kompetencyjne po stronie urzędu marszałkowskiego (19). Nie wskazano natomiast takich odpowiedzi, jak: brak chęci po stronie departamentu czy brak „zielonego światta” ze strony zarządu województwa do nawiązywa- 
nia i prowadzenia współpracy z podmiotami zewnętrznymi. Świadczyć to może o przynajmniej deklaratywnym, pełnym zaangażowaniu we współpracę zewnętrzną zarówno badanych menedżerów, jak i ich kierownictwa. Wyniki te zaprezentowano na rys. 5.8.

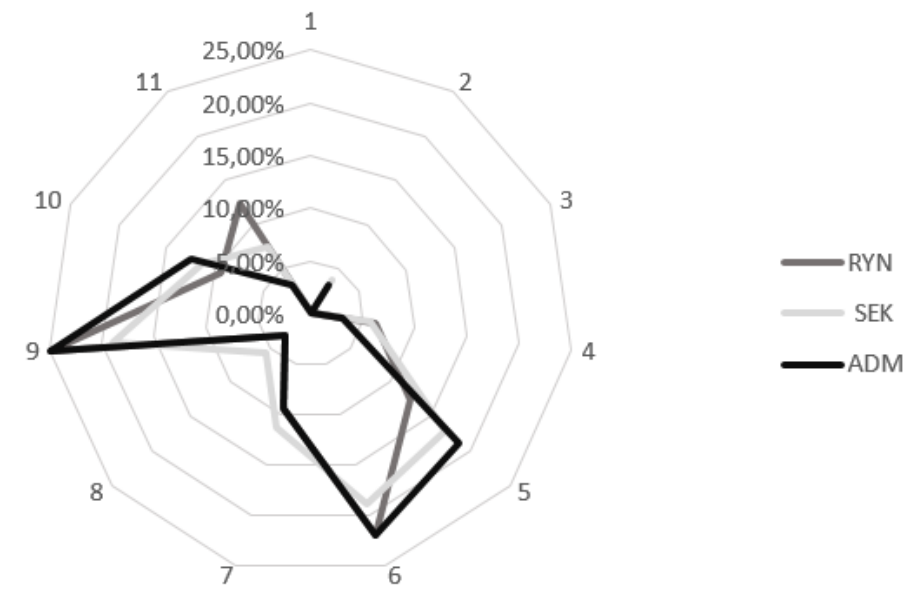

Rys. 5.8. Czynniki utrudniające współpracę zewnętrzną w opinii menedżerów publicznych $(n=43)$

Rodzaj jednostek organizacyjnych: RYN - rynkowe, SEK - sektorowe, ADM - administracyjne; 1. Brak chęci współpracy po stronie departamentu; 2 . Nieprzygotowanie pracowników departamentu do nawiązywania i prowadzenia zewnętrznej współpracy; 3. Brak „zielonego światła”

ze strony zarządu województwa do nawiązywania i prowadzenia współpracy z podmiotami zewnętrznymi; 4. Presja czynników politycznych (osoby reprezentujące organizację - potencjalnego partnera mają odmienne przekonania polityczne niż opcja reprezentowana przez samorząd regionu); 5. Ograniczenia kompetencyjne po stronie urzędu marszałkowskiego; 6. Przepisy prawne ograniczające współpracę (np. przepisy podatkowe); 7. Nieczytelne reguły współpracy; 8. Niechęć potencjalnych partnerów do podejmowania współpracy z departamentem; 9. Roszczeniowe podejście partnerów; 10. Cechy osobowościowe osób reprezentujących partnerów; 11. Inne czynniki, jakie? (proszę wpisać).

Źródło: jak do rys. 5.1.

Warto zauważyć, że jeden z głównych czynników utrudniających współpracę, jakim są przepisy prawa, dotyczy w takim samym stopniu wszystkich rodzajów badanych jednostek organizacyjnych OT. W tej sytuacji trudniejszą sytuację posiadają departamenty rynkowe, których zadania są zorientowane na zewnątrz urzędu. Muszą one bowiem stosować się do przepisów i procedur typowych dla organizacji zamkniętych, o orientacji biurokratycznej. Pozwala im to obciążyć winą za słabą współpracę potencjalnych partnerów. 
Respondenci wymienili też szereg innych czynników utrudniających współpracę, które ich zdaniem nie mieściły się na zaproponowanej liście odpowiedzi. Były one wymieniane zwłaszcza przez przedstawicieli departamentów rynkowych i sektorowych. Warto zacytować kilka z nich: trudności $z$ dotarciem $z$ oferta do potencjalnych partnerów, duża ilość zadań bieżacych $w$ departamencie, co sprawia, że nie ma czasu na szukanie partnerów. Wymieniano również takie czynniki, jak: procedury administracyjne utrudniajace zawiązywanie i prowadzenie partnerstw, brak wypracowanych mechanizmów prowadzenia współpracy i jej form instytucjonalnych czy nieprzygotowanie partnerów.

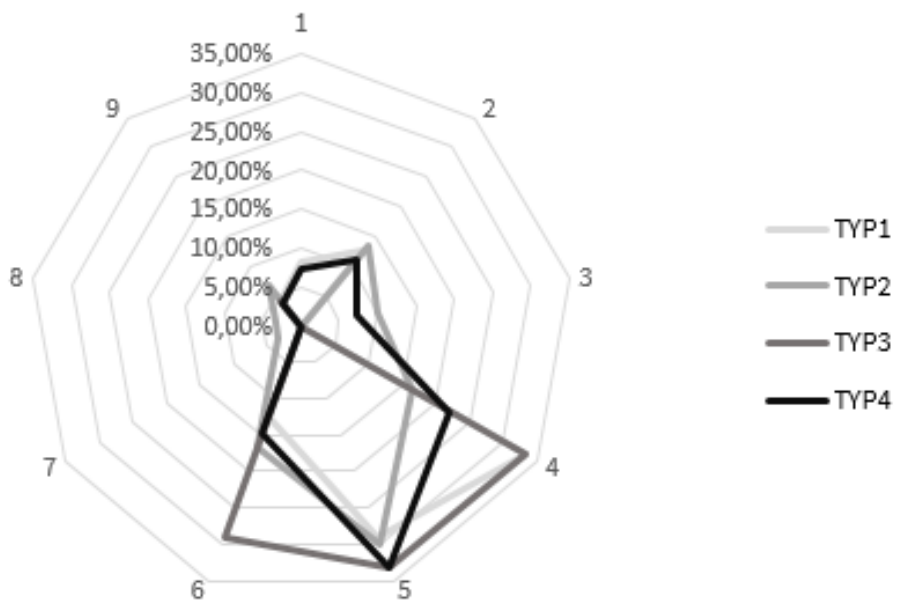

Rys. 5.9. Czynniki sprzyjające współpracy w opinii interesariuszy instytucjonalnych $(n=42)$

Typy badanych podmiotów: TYP 1 - lokalne JST, TYP 2 - administracja państwowa, TYP 3 - uczelnie wyższe, TYP 4 - organizacje okołobiznesowe; 1. Presja na instytucję ze strony członków zarządu województwa/urzędu marszałkowskiego (nakłaniają do współpracy); 2. Przepisy prawne nakłaniające instytucję do współdziałania z samorządem regionu; 3 . Przepisy prawne nakłaniające do działania na rzecz rozwoju regionu; 4. Chęć pozyskania zewnętrznych środków będących w dyspozycji samorządu regionu; 5. Większe możliwości realizacji postawionych przed instytucją zadań; 6 . Chęć skorzystania z doświadczenia, wiedzy, kompetencji innych osób; 7. Czynnik polityki (współpracując z innymi, zyskujemy wyborców); 8. Pewna moda na „współdziałanie”; 9. Inne czynniki, jakie? (proszę wpisać).

Źródło: jak do rys. 5.1.

Przejdźmy obecnie do określenia czynników skłaniających interesariuszy instytucjonalnych do współpracy $\mathrm{z}$ urzędem marszałkowskim (rys. 5.9). Wymieniali oni najczęściej większe możliwości realizacji postawionych przed instytucja zadań. Tylko nieco mniej popularny okazał się czynnik: chęć pozyskania zewnętrznych środków będacych $w$ dyspozycji samorządu regionu. Na trzecim miejscu w rankingu znalazła się: chęć sko- 
rzystania z doświadczenia, wiedzy, kompetencji innych osób. Są to czynniki przynoszące wymierne korzyści dla interesariuszy instytucjonalnych. Wynika z tego, że takie właśnie korzyści, a nie presja ze strony samorządu regionu do podejmowania współpracy czy obowiązek współpracy wynikający z przepisów prawa, są podstawowymi stymulatorami współpracy partnerskiej w kontekście rozwoju gospodarczego regionu.

Warto podkreślić, że największą zgodnością odpowiedzi wykazali się przedstawiciele uczelni wyższych. Praktycznie wszyscy wymienili te same trzy kategorie odpowiedzi $(\mathrm{nr} \mathrm{4,} \mathrm{5,6).} \mathrm{Natomiast} \mathrm{przedstawiciele}$ organizacji okołobiznesowych najczęściej wskazywali tu odpowiedź nr 6 - większe możliwości realizacji postawionych przed instytucją zadań.

\subsubsection{Czynniki charakteryzujące współpracę organizacji terytorialnej z podmiotami publicznymi}

Przyjrzyjmy się obecnie czynnikom charakteryzującym współpracę OT z poszczególnymi typami podmiotów publicznych. Zaprezentujemy więc opinie menedżerów publicznych na temat ich współpracy z: jednostkami samorządu terytorialnego (JST) z obszaru województwa, wojewodą i jego służbami, administracją państwową (centralną), samorządami innych województw, publicznymi szkołami wyższymi, organizacjami międzynarodowymi i regionami innych państw. W dalszych rozważaniach przedstawimy czynniki skłaniające do współpracy oraz czynniki ograniczające czy utrudniające taką współpracę, kolejno z wymienionymi wyżej podmiotami publicznymi.

\section{Jednostki Samorządu Terytorialnego (JST)}

Rozkład czynników skłaniających OT do współpracy z lokalnymi JST został zilustrowany na rys. 5.10. Wśród czynników zachęcających do współpracy najczęściej wskazywane były oczekiwane przez te podmioty korzyści (odpowiedzi 6 i 7). Najliczniej tę pierwszą odpowiedź wskazywali przedstawiciele departamentów administracyjnych (33\%). Menedżerowie z departamentów sektorowych, częściej niż inni, wskazywali na czynnik presji podmiotów z regionu chcacych współdziałać (17\%) oraz obowiązek współdziałania wynikajacy z przepisów europejskich (17\%).

W przypadku menedżerów z departamentów rynkowych odnotowano najbardziej równomierny rozkład odpowiedzi. Praktycznie każda kategoria odpowiedzi została wskazana przez przynajmniej kilku respondentów. W dodatku liczba wskazań poszczególnych czynników była wyraźnie wyrównana. Oznacza to, że menedżerów z departamentów rynkowych skłaniają do współpracy z JST różnorodne czynniki, co 
może oznaczać ich silną determinację do współpracy. Wśród czynników wymienianych dodatkowo przez respondentów (odpowiedź nr 10) można podać: możliwość szerokiego oddziaływania w regionie, osiaganie zadowalających rezultatów realizowanych projektów oraz sprawne wdrażanie funduszy.

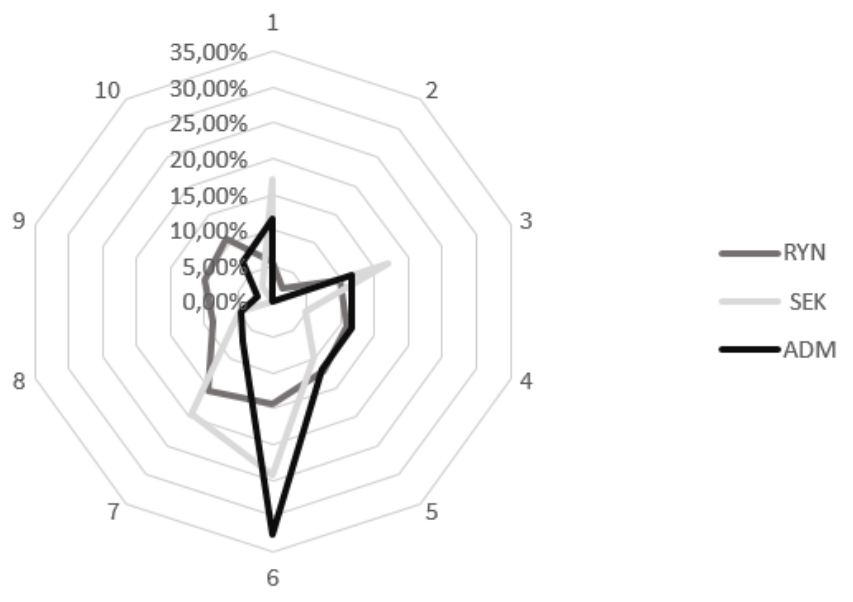

Rys. 5.10. Czynniki skłaniające do współpracy menedżerów publicznych z lokalnymi JST $(n=43)$

Rodzaj jednostek organizacyjnych: RYN - rynkowe, SEK - sektorowe, ADM - administracyjne; 1. Presja podmiotów publicznych z regionu chcących współdziałać (potencjalni partnerzy sami zabiegają u dyrekcji departamentu o wspólne przedsięwzięcia); 2. Presja na departament ze strony członków zarządu województwa, aby nawiązywać szersze kontakty z potencjalnymi partnerami; 3. Obowiązek współdziałania wynikający z przepisów krajowych (ustawa o samorządzie województwa, art. 12.1); 4. Zasada partnerstwa wynikająca z przepisów europejskich (Rozporządzenie 1083/06); 5. Chęć pozyskania zewnętrznych środków; 6. Większe możliwości realizacji postawionych przed samorządem zadań; 7. Chęć skorzystania z doświadczenia, wiedzy, kompetencji innych podmiotów; 8. Czynnik lokalnej polityki (współpracując z innymi, zyskujemy wyborców); 9. Pewna moda na „współdziałanie” wynikająca z ogólnego stylu działań JST; 10. Inne czynniki, jakie? (proszę wpisać).

Źródło: jak do rys. 5.1.

Rozkład czynników utrudniających współpracę z JST zaprezentowano na rys. 5.11. Menedżerowie z departamentów rynkowych najczęściej dopatrywali się utrudnień we współpracy z lokalnymi JST w roszczeniowym podejściu partnerów (22\%). Trzy inne czynniki o identycznej liczbie wskazań (około 16\%) to: ograniczenia natury prawno-administracyjnej, nieczytelne reguły współpracy oraz niechęć JST do podejmowania wspótpracy $z$ departamentem. Faktycznie, lokalne JST mogą postrzegać regionalną administrację publiczną głównie jako źródło funduszy unijnych, za sprawą roli, jaką samorząd województwa odgrywa w procesie planowa- 
nia i realizacji polityki spójności UE. W tej sytuacji budowanie równorzędnych relacji pomiędzy samorządem regionu a lokalnymi JST mimo ich formalnej niezależności jest problematyczne.

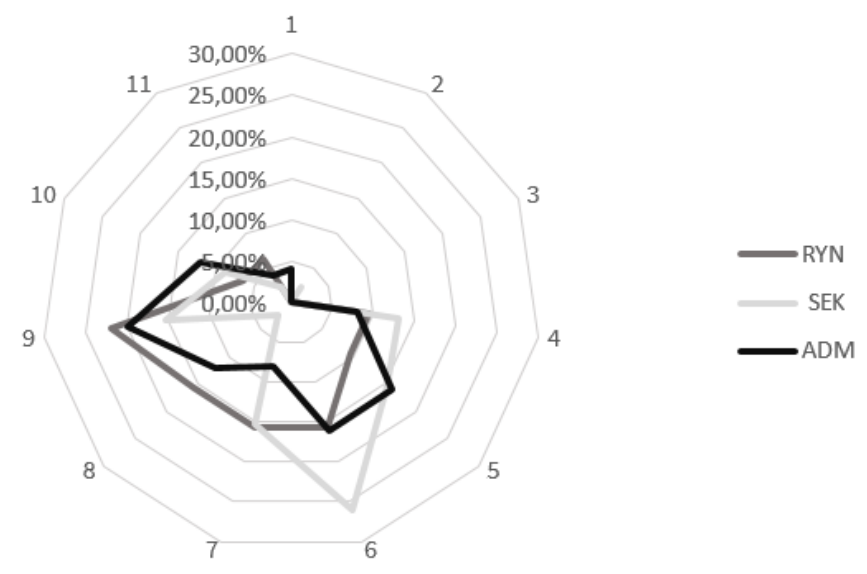

Rys. 5.11. Czynniki utrudniające współpracę menedżerów publicznych z lokalnymi JST $(n=43)$

Rodzaj jednostek organizacyjnych: RYN - rynkowe, SEK - sektorowe, ADM - administracyjne; 1. Brak chęci współpracy po stronie departamentu; 2 . Nieprzygotowanie pracowników departamentu do nawiązywania i prowadzenia zewnętrznej współpracy; 3. Brak „zielonego światła” ze strony zarządu do nawiązywania współpracy zewnętrznej; 4. Czynniki polityczne (osoby reprezentujące organizację - potencjalnego partnera - mają odmienne przekonania polityczne niż opcja reprezentowana przez samorząd regionu); 5. Ograniczenia kompetencyjne po stronie urzędu marszałkowskiego; 6. Przepisy prawne ograniczające współpracę (np. przepisy podatkowe); 7. Nieczytelne reguły współpracy; 8 . Niechęć potencjalnych partnerów publicznych do podejmowania współpracy z departamentem; 9. Roszczeniowe podejście partnerów; 10. Cechy osobowościowe osób reprezentujących partnerów publicznych; 11. Inne, jakie? (proszę wpisać).

Źródło: jak do rys. 5.1.

W przypadku departamentów sektorowych, najwięcej wskazań miały: przepisy prawne ograniczające współpracę. Natomiast w przypadku departamentów administracyjnych dominującą odpowiedzią było roszczeniowe podejście partnerów (20\%).

\section{Wojewoda i jego służby}

Menedżerowie publiczni byli również pytani o czynniki stymulujące współpracę z wojewodą oraz podległym mu aparatem administracyjnym. Dominowały tu wyraźnie czynniki prawno-administracyjne. Rozkład poszczególnych odpowiedzi zaprezentowano na rys. 5.12. Obowiqzek współdziałania wynikajacy z przepisów krajowych (odpowiedź 3) został wskazany niemal zgodnie przez wszystkich przedstawicieli trzech 
rodzajów departamentów. Zauważalny jest również czynnik: większe możliwości realizacji postawionych przed samorządem zadań (odpowiedź 6), co dostrzegli zwłaszcza menedżerowie $z$ departamentów sektorowych i rynkowych (odpowiednio: 23\% i 19\%). Na uwagę zasługuje jedna z wypowiedzi menedżera $\mathrm{z}$ departamentu rynkowego, w której zaznaczono, że: region występujacy wspólnie jako całość ma siłę, inwestorzy lokuja się tam, gdzie jest współdziałanie, a nie konflikty czy rywalizacja.

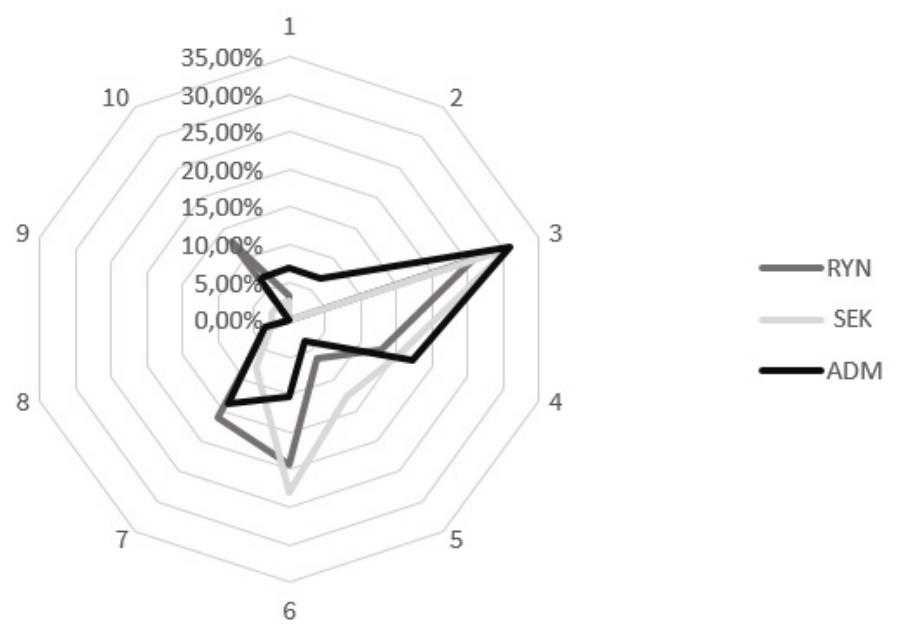

Rys. 5.12. Czynniki skłaniające menedżerów publicznych do współpracy z wojewodą oraz podległym mu aparatem administracyjnym $(n=43)$

Rodzaj jednostek organizacyjnych: RYN - rynkowe, SEK - sektorowe, ADM - administracyjne; 1. Presja podmiotów publicznych z regionu chcących współdziałać (potencjalni partnerzy sami zabiegają u dyrekcji departamentu o wspólne przedsięwzięcia); 2. Presja na departament ze strony członków zarządu województwa, aby nawiązywać szersze kontakty z potencjalnymi partnerami; 3. Obowiązek współdziałania wynikający z przepisów krajowych (ustawa o samorządzie województwa, art. 12.1); 4. Zasada partnerstwa wynikająca z przepisów europejskich (Rozporządzenie 1083/06); 5. Chęć pozyskania zewnętrznych środków; 6. Większe możliwości realizacji postawionych przed samorządem zadań; 7. Chęć skorzystania z doświadczenia, wiedzy, kompetencji innych podmiotów; 8. Czynnik lokalnej polityki (współpracując z innymi, zyskujemy wyborców); 9. Pewna moda na „współdziałanie” wynikająca z ogólnego stylu działań JST; 10. Inne czynniki, jakie? (proszę wpisać).

Źródło: jak do rys. 5.1.

Jako czynniki ograniczające współpracę z wojewodą respondenci wskazywali: przepisy prawne ograniczajace wspótpracę oraz ograniczenia kompetencyjne po stronie urzędu marszałkowskiego. Te i inne czynniki, zaliczane ogólnie do przepisów prawno-administracyjnych, były najczęściej wymieniane przez przedstawicieli departamentów rynkowych. 
Rozkład czynników ograniczających współpracę z wojewodą został przedstawiony na rys. 5.13. Sporadycznie pojawiały się też odpowiedzi dodatkowe, poza wymienionymi na rysunku.

Jeden $\mathrm{z}$ respondentów z departamentów administracyjnych wymienił następującą barierę: fakt braku związku formalno-prawnego departamentu z sama instytucją urzędu wojewódzkiego i wojewody ogranicza tę wspótpracę. Jest to interesująca, choć zaskakująca wypowiedź. Przejawia się tu pogląd, że współpraca między instytucjami publicznymi powinna mieć mocne podstawy formalne, które w kontekście funkcji kontrolnych wojewody mogą sprawić, że wspomniana relacja nie będzie miała równorzędnego charakteru.

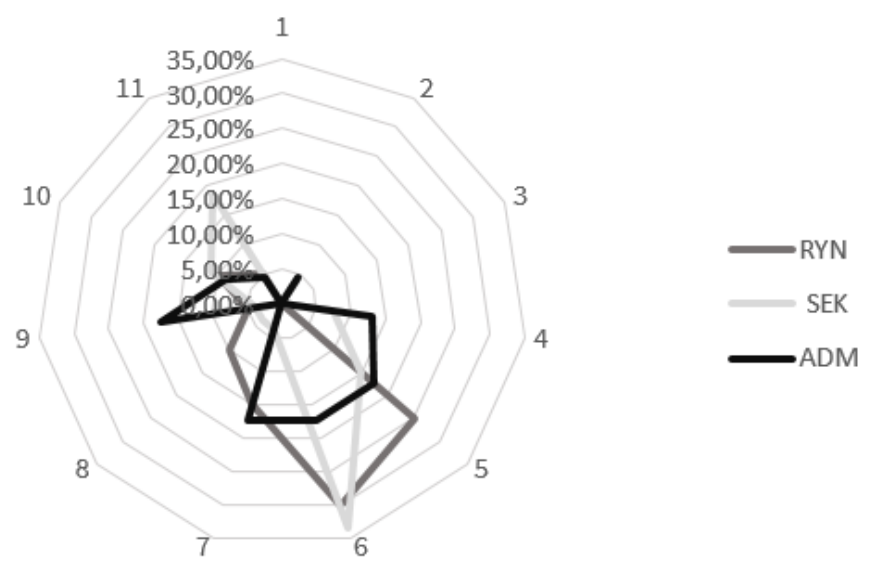

Rys. 5.13. Czynniki utrudniające menedżerom publicznym współpracę z wojewodą oraz podległym mu aparatem administracyjnym $(n=43)$

Rodzaj jednostek organizacyjnych: RYN - rynkowe, SEK - sektorowe, ADM - administracyjne; 1. Brak chęci współpracy po stronie departamentu; 2 . Nieprzygotowanie pracowników departamentu do nawiązywania i prowadzenia zewnętrznej współpracy; 3. Brak „zielonego światta”

ze strony zarządu do nawiązywania współpracy zewnętrznej; 4. Czynniki polityczne (osoby reprezentujące organizację - potencjalnego partnera mają odmienne przekonania polityczne niż opcja reprezentowana przez samorząd regionu); 5. Ograniczenia kompetencyjne po stronie urzędu marszałkowskiego; 6. Przepisy prawne ograniczające współpracę (np. przepisy podatkowe); 7. Nieczytelne reguły współpracy; 8 . Niechęć potencjalnych partnerów publicznych do podejmowania współpracy z departamentem; 9. Roszczeniowe podejście partnerów; 10. Cechy osobowościowe osób reprezentujących partnerów publicznych; 11. Inne, jakie? (proszę wpisać).

Źródło: jak do rys. 5.1.

\section{Publiczne szkoły wyższe}

Wobec tej kategorii partnera organizacji terytorialnej zaobserwowano relatywną zgodność menedżerów departamentów rynkowych i sektorowych. Wśród czynników skłaniających do współpracy zdecydo- 
wanie wyróżniają się tu: większe możliwości realizacji postawionych przed samorząem zadań oraz chęć skorzystania $z$ doświadczeń, wiedzy i kompetencji innych podmiotów. Ten ostatni czynnik wymieniany był najczęściej przez menedżerów departamentów administracyjnych. Menedżerowie ci wskazywali również na przepisy prawno-administracyjne oraz na czynniki związane z wpływem otoczenia. Takie inicjatywy, jak ubieganie się o patronat Marszałka dla konferencji organizowanych przez uczelnie czy chęć pozyskania dodatkowych środków na różne przedsięwzięcia trafiają właśnie do takich departamentów. Respondenci wymieniali również wiele innych czynników uzasadniających taką współpracę, do których należą: bez współpracy ze szkołami wyższymi nie da się osiagnać wysokiego poziomu rozwoju województwa; występujemy jako region wspólnie z uczelniami. Rozkład odpowiedzi dotyczących współpracy z uczelniami publicznymi zaprezentowano na rys. 5.14.

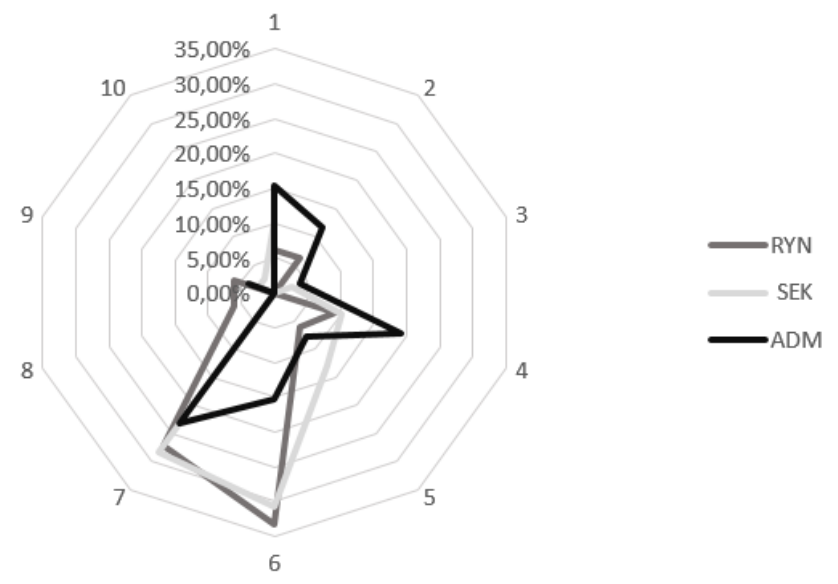

Rys. 5.14. Czynniki skłaniające menedżerów publicznych do współpracy

z uczelniami publicznymi $(n=43)$

Rodzaj jednostek organizacyjnych: RYN - rynkowe, SEK - sektorowe, ADM - administracyjne; 1. Presja podmiotów publicznych z regionu chcących współdziałać (potencjalni partnerzy sami zabiegają u dyrekcji departamentu o wspólne przedsięwzięcia); 2. Presja na departament ze strony członków zarządu województwa, aby nawiązywać szersze kontakty z potencjalnymi partnerami; 3. Obowiązek współdziałania wynikający z przepisów krajowych (ustawa o samorządzie województwa, art. 12.1); 4. Zasada partnerstwa wynikająca z przepisów europejskich (Rozporządzenie 1083/06); 5. Chęć pozyskania zewnętrznych środków; 6. Większe możliwości realizacji postawionych przed samorządem zadań; 7. Chęć skorzystania z doświadczenia, wiedzy, kompetencji innych podmiotów; 8. Czynnik lokalnej polityki (współpracując z innymi, zyskujemy wyborców); 9. Pewna moda na „współdziałanie” wynikająca z ogólnego stylu działań JST; 10. Inne czynniki, jakie? (proszę wpisać).

Źródło: jak do rys. 5.1 . 
Respondenci wskazywali również na szereg utrudnień dla współpracy z uczelniami publicznymi. Zilustrowano to na rys. 5.15. Zdecydowanie dominującym czynnikiem $w$ tej kategorii stały się przepisy prawne. Najczęściej czynnik ten był wskazywany przez respondentów z departamentów administracyjnych (łącznie $60 \%$ odpowiedzi), ale był też dominujący w przypadku menedżerów z departamentów rynkowych i sektorowych (odpowiednio: 38\% i 40\%).

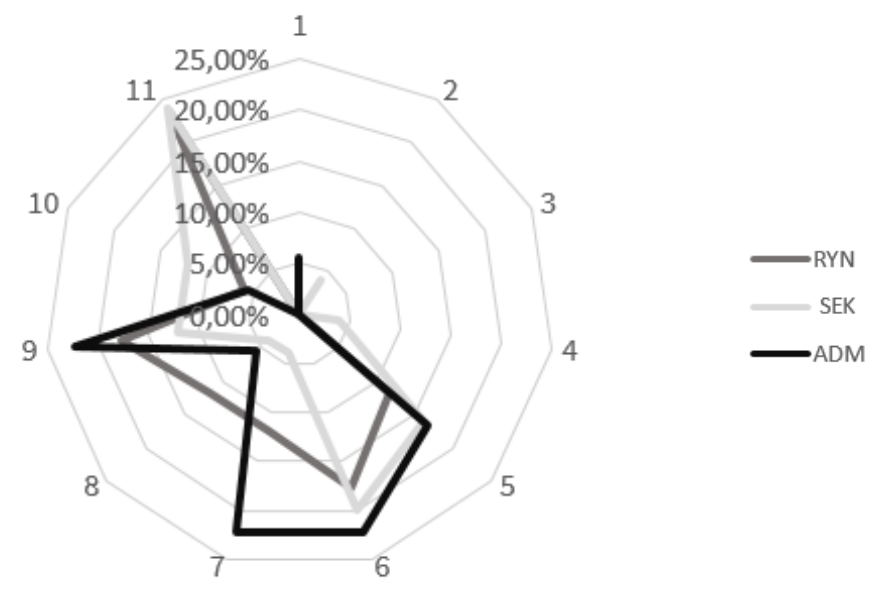

Rys. 5.15. Czynniki utrudniające menedżerom publicznym współpracę ze szkołami wyższymi $(n=43)$

Rodzaj jednostek organizacyjnych: RYN - rynkowe, SEK - sektorowe, ADM - administracyjne; 1. Brak chęci współpracy po stronie departamentu; 2 . Nieprzygotowanie pracowników departamentu do nawiązywania i prowadzenia zewnętrznej współpracy; 3. Brak „zielonego światła”

ze strony zarządu do nawiązywania współpracy zewnętrznej; 4. Czynniki polityczne (osoby reprezentujące organizację - potencjalnego partnera - mają odmienne przekonania polityczne niż opcja reprezentowana przez samorząd regionu); 5. Ograniczenia kompetencyjne po stronie urzędu marszałkowskiego; 6. Przepisy prawne ograniczające współpracę (np. przepisy podatkowe); 7. Nieczytelne reguły współpracy; 8 . Niechęć potencjalnych partnerów publicznych do podejmowania współpracy z departamentem; 9. Roszczeniowe podejście partnerów; 10. Cechy osobowościowe osób reprezentujących partnerów publicznych; 11. Inne, jakie? (proszę wpisać).

Źródło: jak do rys. 5.1.

Warto zauważyć, że menedżerowie publiczni niemal nie dostrzegli ograniczeń do współpracy po stronie swojej organizacji, w tym uwarunkowań politycznych. Taka postawa może utrudniać realizację potrzebnych zmian, a więc i tworzenie sprzyjających warunków do współpracy. Respondenci formułowali jednocześnie wiele czynników dodatkowych, 
do których należą: brak oferty ze strony uczelni do wspótpracy, brak podejmowania bardziej ryzykownych działan - oferta ogranicza się do przeprowadzenia badań czy organizacji szkoleń; potrzebna zmiana mentalności władz uczelni, niechęć do wspótpracy wzajemnej między uczelniami, odmienne interesy podmiotów, ograniczenia departamentu $w$ finansowaniu przedsięwzięć uczelni.

\section{Centralna administracja rządowa}

W przypadku centralnej administracji rządowej odnotowano relatywnie duże różnice w odpowiedziach menedżerów urzędów marszałkowskich. W grupie menedżerów rynkowych, jako skłaniający do współpracy np. z ministerstwami, najwięcej wskazań uzyskał czynnik: chęć skorzystania $z$ doświadczenia, wiedzy, kompetencji innych podmiotów (29\%). W przypadku menedżerów z departamentów sektorowych - większe możliwości realizacji postawionych przed samorzadem zadań (32\%). Natomiast w przypadku menedżerów kierujących departamentami administracyjnymi - obowiązek współdziałania wynikający z przepisów krajowych (39\%). Wyniki takie potwierdzają celowość dokonanego wcześniej podziału na trzy rodzaje departamentów. Menedżerowie departamentów rynkowych wskazywali często na czynniki przynoszące konkretne korzyści. Wskazywano również, chociaż dużo rzadziej, na przepisy prawne promujące współdziałanie. Natomiast czynniki związane z wpływem otoczenia nie zostały dostrzeżone przez respondentów.

Jeżeli chodzi o czynniki utrudniające współpracę z administracją centralną, to $\mathrm{w}$ przypadku menedżerów $\mathrm{z}$ departamentów rynkowych dominują odpowiedzi wskazujące na ograniczenia kompetencyjne oraz przepisy prawne, a także na cechy osobowościowe czy podejście roszczeniowe partnerów. Respondenci zgłaszali też wiele dodatkowych utrudnień, takich jak: niechęć urzędników $z$ ministerstw do udzielania odpowiedzi na pytania $i$ wątpliwości pochodzące $z$ regionów, zmieniające się przepisy prawne, trudności z bezpośrednimi kontaktami z ministerstwami, deficyt środków finansowych po stronie podmiotów państwowych, nieczytelne przepisy prawa tworzone przez administracje państwowa czy duża odległość od siedzib centralnych instytucji.

\section{Samorządy innych województw w Polsce}

Dużą zgodność wykazali menedżerowie urzędów marszałkowskich, odnosząc się do czynników sprzyjających współpracy z innymi regionami (urzędami marszałkowskimi). Respondenci najczęściej wskazywali tu czynniki związane z generowaniem wymiernych korzyści dla ich organizacji. Dominowały takie odpowiedzi, jak: chęć skorzystania $z$ doświadczenia, wiedzy, kompetencji innych podmiotów czy większe możli- 
wości realizacji postawionych przed samorządem zadań. W przypadku departamentów rynkowych dodatkowo zauważono relatywnie duży udział czynników indywidualnie wskazanych przez respondentów, takich jak: coraz częstsza realizacja wspólnych przedsięwzięć, pogłębiająca się wspótpraca pomiędzy samorządami województw. Warto odnotować też następującą wypowiedź menedżera departamentu rynkowego: stworzenie zupełnie nowej wartości, czegoś czego jeszcze nie było (przykład Stowarzyszenia na rzecz Bio- i Nanoregionu powołanego przez samorządy województw).

Warto jeszcze wspomnieć o istotnej roli przepisów prawno-administracyjnych $\mathrm{w}$ nawiązywaniu i prowadzeniu współpracy z innymi urzędami marszałkowskimi. Wskazało na nie 13\% menedżerów rynkowych, $16 \%$ menedżerów z departamentów sektorowych i 19\% z departamentów administracyjnych.

Respondenci wskazywali również na utrudnienia we współpracy z innymi urzędami marszałkowskimi. Stosunkowo często wymieniano nieczytelne reguły współpracy, co najbardziej zostało zaakcentowane przez menedżerów rynkowych i administracyjnych. Menedżerowie administracyjni zwrócili również uwagę na słabe zaangażowanie swojego departamentu we współpracę z innymi urzędami marszałkowskimi w Polsce (17\%). W przypadku menedżerów $\mathrm{z}$ departamentów rynkowych relatywnie często wymieniano dodatkowe czynniki, takie jak: brak lub ograniczone środki finansowe na taka wspólpracę, brak potrzeby szerszej wspólpracy $z$ innymi samorządami w Polsce, odmienne interesy poszczególnych samorządów.

\section{Organizacje międzynarodowe i regiony innych państw}

Respondenci z departamentów sektorowych i rynkowych mocno zaakcentowali takie czynniki skłaniające do współpracy z podmiotami zagranicznymi, jak chęć skorzystania $z$ doświadczenia, wiedzy, kompetencji tych podmiotów (odpowiednio: 33\% i 26\%). Wskazuje to na ich postawy ukierunkowane na procesy uczenia się od podmiotów zagranicznych. W przypadku menedżerów departamentów administracyjnych odpowiedzi rozłożyły się równomiernie i nie odnotowano jednego czynnika, który wyróżniłby się na tle innych. Wśród wskazań dodatkowych pojawiały się takie, jak: dzielenie się wiedza, wymiana doświadczeń, promocja własnego regionu, tworzenie nowej jakości oraz wykreowanie rynku zbytu dla własnych produktów.

Wśród czynników utrudniających współpracę z organizacjami międzynarodowymi i regionami $\mathrm{z}$ innych państw wymieniano głównie czynniki prawno-administracyjne. Około 50\% odpowiedzi wszystkich respondentów dotyczyło właśnie takich czynników. W grupie respon- 
dentów z departamentów administracyjnych najczęstszymi wskazaniami były: nieprzygotowanie pracowników departamentu do nawiązywania i prowadzenia zewnętrznej wspótpracy. Dla departamentów sektorowych były to nieczytelne reguły wspótpracy. W przypadku menedżerów rynkowych i sektorowych odnotowano relatywnie dużo wskazań dodatkowych, takich jak: słaba znajomość języków obcych, brak środków na współdziałanie, mniejsze środki w krajach Europy Zachodniej na realizację wspólnych projektów, brak potrzeby współpracy w przypadku departamentu, niechęć do wspótpracy niektórych krajów Europy Centralnej i Wschodniej.

\subsubsection{Czynniki charakteryzujące współpracę organizacji terytorialnej z partnerami niepublicznymi}

Menedżerowie publiczni byli proszeni o dokonanie charakterystyki współpracy z partnerami niepublicznymi. Mieli oni określić czynniki takiej współpracy z samorządem gospodarczym, samorządem zawodowym, organizacjami pozarządowymi, prywatnymi szkołami wyższymi oraz indywidualnymi przedsiębiorstwami. Respondenci mieli wskazać bariery bądź ograniczenia utrudniające taką współpracę. Niżej omówimy kolejno czynniki takiej współpracy z wymienionymi podmiotami, a następnie wskażemy na ograniczenia, na jakie napotyka ta współpraca.

Dla uproszczenia dalszej analizy wspomniane czynniki podzielono na trzy grupy:

- czynniki bezpośrednich korzyści ze współpracy zewnętrznej dla danej jednostki organizacyjnej urzędu marszałkowskiego;

- czynniki otoczenia dalszego, w tym przepisy prawno-administracyjne, które zobowiązują menedżerów do podejmowania i prowadzenia współpracy zewnętrznej;

- czynniki wpływu (presji) na współpracę ze strony otoczenia podmiotowego (potencjalnych partnerów).

Warto zaznaczyć, że w przypadku podmiotów niepublicznych respondenci ograniczali się głównie do wskazania czynników z zaproponowanej listy. Tylko sporadycznie dopisywali inne.

\section{Samorząd gospodarczy}

Menedżerowie publiczni, charakteryzując współpracę z samorządem gospodarczym, wskazywali na ważną rolę presji podmiotów zewnętrznych. Najwięcej wskazań mieli pod tym względem przedstawiciele departamentów administracyjnych (25\% dla tej grupy czynników). Tylko nieco mniej - menedżerowie departamentów sektorowych (22\%) oraz 
rynkowych (14\%). Interpretując te wyniki, warto zauważyć, że wśród menedżerów z departamentów administracyjnych znaleźli się też tacy, którzy uczestniczą w procesie dystrybucji środków unijnych. Beneficjentami tych środków są m.in. organizacje samorządu gospodarczego, co mogło wpłynąć na ich odpowiedzi. Jeżeli chodzi o czynniki prawno-administracyjne, to należy odnotować, że większą wagę przywiązywali do nich dyrektorzy z departamentów administracyjnych (25\%) niż dyrektorzy z departamentów rynkowych (18\%) czy administracyjnych (17,39\%).

$\mathrm{Na}$ uwagę zasługuje fakt, że najwięcej czynników skłaniających do współpracy ze względu na bezpośrednie korzyści odnotowano w przypadku menedżerów departamentów rynkowych (68\%), mniej w przypadku menedżerów z departamentów sektorowych (57\%), a najmniej w przypadku menedżerów departamentów administracyjnych (50\%). Menedżerowie $\mathrm{z}$ departamentów rynkowych najczęściej wskazywali na większe możliwości realizacji postawionych przed samorzadem zadań (35,71\%) oraz chęć skorzystania z doświadczenia, wiedzy, kompetencji samorzadu gospodarczego.

Według respondentów na współpracę z samorządem gospodarczym negatywnie wpływają ograniczenia po stronie przepisów prawnych, na które wskazała ponad połowa badanych $\mathrm{z}$ departamentów rynkowych. Menedżerowie z departamentów sektorowych i administracyjnych najczęściej wskazywali na: ograniczenia kompetencyjne po stronie urzędu marszałkowskiego (odpowiednio: 30\% i 21\%), natomiast menedżerowie z departamentów rynkowych wymieniali ten czynnik sporadycznie (9\%). Wiele wskazuje na to, że ci ostatni, ze względu na zewnętrzne nastawienie, ewentualne bariery dostrzegają raczej poza urzędem, w tym w zasadach współdziałania międzyorganizacyjnego. Menedżerowie departamentów rynkowych, częściej niż pozostali, wymieniali czynniki dodatkowe utrudniające współpracę, takie jak: niezrozumienie przez przedstawicieli samorządu gospodarczego przepisów, którym departament musi się podporządkować, rozbieżne oczekiwania urzędu i partnerów reprezentujących przedsiębiorców, deficyt środków finansowych u organizacji samorzadu gospodarczego. Jednocześnie respondenci niemal nie dostrzegali utrudnień po stronie swoich departamentów.

\section{Samorząd zawodowy}

Wśród czynników skłaniających do współpracy z samorządem zawodowym respondenci akcentowali głównie bezpośrednie korzyści ze współpracy. Wskazywali na nie najczęściej przedstawiciele departamentów sektorowych (73\%), rzadziej przedstawiciele departamentów rynkowych (48\%) czy administracyjnych (38\%). Menedżerowie z departamentów sektorowych często wskazywali również na większe 
możliwości realizacji stawianych przed samorządem zadań (42\%). Dla departamentów rynkowych czynnik ten ma zdecydowanie mniejsze znaczenie, zaś ich zaangażowanie we współpracę tłumaczyć można modą na współdziałanie.

Menedżerowie z departamentów rynkowych wśród czynników utrudniających współpracę z samorządem zawodowym wskazywali ogólnie na przepisy prawa (23\%). Warto jednak zauważyć, że przedstawiciele dwóch pozostałych rodzajów departamentów częściej wskazywali na czynnik pozostający po stronie organizacji - ograniczenia kompetencyjne po stronie urzędu marszałkowskiego (odpowiednio: 28\% i 25\%). O ile czynniki polityczne $\mathrm{w}$ odniesieniu do poszczególnych grup partnerów niepublicznych niemal nie były wskazywane, to wyjątkowo, w przypadku samorządu zawodowego, czynnik ten się pojawił (15\%). Relatywnie często przedstawiciele departamentów rynkowych wymieniali jako czynniki dodatkowe: brak wspólnych pól działania, niezrozumienie przepisów departamentu, odmienne cele.

\section{Organizacje pozarządowe}

Wśród czynników skłaniających do współpracy z organizacjami pozarządowymi, widoczne było pewne zróżnicowanie odpowiedzi respondentów według rodzajów departamentów, którymi kierują. W przypadku jednostek rynkowych oraz administracyjnych najczęściej wskazywano większe możliwości realizacji postawionych przed samorzadem zadań (odpowiednio 33\% i 28\%). Dla departamentów sektorowych był to obowiązek wspótdziałania wynikajacy z przepisów krajowych (25\%). Mniejszy wpływ na podejmowanie współpracy $\mathrm{z}$ organizacjami pozarządowymi wywierało otoczenie podmiotowe.

$\mathrm{Na}$ pytanie o utrudnienia we współpracy respondenci z departamentów rynkowych nie wskazali na dominujące pod tym względem czynniki. Wskazania rozłożyły się względnie równomiernie, co może pokazywać, że współpraca $z$ tym partnerem nie odgrywa znaczącej roli. Czynniki najczęściej wskazane przez menedżerów departamentów rynkowych to: nieprzygotowanie pracowników departamentu do nawiazywania i prowadzenia zewnętrznej wspólpracy oraz przepisy prawne ograniczajace wspótpracę (po 15\% wskazań). Menedżerowie z tych departamentów wymieniali również takie czynniki dodatkowe, jak: niska wiedza NGO-ów o systemie rozliczeń w sektorze publicznym, deficyt wiedzy działaczy organizacji samorządowych $w$ zakresie przepisów prawa czy brak ogólnych kompetencji do prowadzenia działań o charakterze formalnym. W przypadku obu pozostałych grup menedżerów wskazania dotyczące ograniczeń współpracy rozłożyły się dość równomiernie na liście wymienionych czynników. 


\section{Prywatne szkoły wyższe}

Wśród czynników stymulujących współpracę między urzędem marszałkowskim i prywatnymi szkołami wyższymi respondenci wyraźnie wskazywali na „korzyści dla departamentu”. Najczęstszą odpowiedzią w przypadku menedżerów departamentów rynkowych i sektorowych była chęć skorzystania $z$ doświadczenia, wiedzy, kompetencji prywatnych szkół wyższych (odpowiednio 40\% i 54\%). Interesujące jest również to, że w przypadku departamentów administracyjnych najczęściej wymieniano obowiązek współdziałania wynikający z przepisów krajowych (24\%).

Do czynników ograniczających współpracę z prywatnymi szkołami wyższymi, menedżerowie z departamentów rynkowych zaliczyli przede wszystkim: ograniczenia kompetencyjne po stronie urzędu marszałkowskiego (25\%). Wśród pojawiających się wskazań zauważalne były też: niechęć prywatnych szkót wyższych do podejmowania wspólpracy z departamentem (17\%) oraz przepisy prawne ograniczające wspótprace (17\%). Interesujące jest również to, że w przypadku menedżerów z departamentów administracyjnych aż $29 \%$ wskazań dotyczyło nieczytelnych reguł wspótpracy.

\section{Indywidualne przedsiębiorstwa}

Spośród czynników stymulujących współpracę $\mathrm{z}$ indywidualnymi przedsiębiorstwami menedżerowie rynkowi wymieniali najczęściej: większe możliwości realizacji postawionych przed samorzadem zadań oraz chęć skorzystania $z$ doświadczenia, wiedzy, kompetencji przedsiębiorstw (po 39\%). Odpowiedzi takie wskazują na wagę, jaką przykładają te departamenty do współpracy z podmiotami gospodarczymi. Menedżerowie z departamentów administracyjnych wskazywali najczęściej (29\%) na obowiązek współdziałania wynikający z przepisów prawa. Dodajmy, że szefowie departamentów rynkowych i sektorowych ani razu nie wskazali tego czynnika $\mathrm{w}$ odniesieniu do współpracy $\mathrm{z}$ przedsiębiorstwami.

Respondenci z departamentów rynkowych za czynniki ograniczające współpracę z przedsiębiorstwami uznali przede wszystkim czynniki prawno-administracyjne, $\mathrm{w}$ tym szczególnie przepisy prawne ograniczające wspótpracę (33\%).

\subsubsection{Pożądane cechy publicznego i niepublicznego partnera do współpracy}

Respondenci zostali poproszeni o charakterystykę idealnego partnera do współpracy dla reprezentowanej przez nich organizacji (urzędu marszałkowskiego) - oddzielnie publicznego i niepublicznego. Konstrukcja 
pytania umożliwiała zaznaczenie cech idealnego partnera (15 możliwości) oraz dodania innych, dodatkowych cech (pozycja 16). Poszczególne cechy można pogrupować według trzech kategorii związanych z następującymi rodzajami zasobów: (1) finansowych, (2) intelektualnych, (3) relacyjnych. Przyjęto, że w tej ostatniej kategorii znajdą się cechy osobowościowe, mające wpływ na interakcje relacyjne.

Rozkład odpowiedzi w odniesieniu do pożądanych cech partnera publicznego (z podziałem na trzy rodzaje departamentów) przedstawiono na rys. 5.16. Należy podkreślić, że analiza rozkładu odpowiedzi pod kątem wspomnianych kategorii jednoznacznie wskazuje na zasoby relacyjne jako najbardziej cenione wśród partnerów publicznych. Podobny wniosek można wyciągnąć, przyglądając się strukturze odpowiedzi w odniesieniu do każdego z trzech rodzajów departamentów. W przypadku departamentów rynkowych i sektorowych najczęściej wymienianą cechą była wiarygodność partnera (odpowiednio 22\% i 24\%). Natomiast wśród menedżerów departamentów administracyjnych była to odpowiedzialność $(22 \%)$.

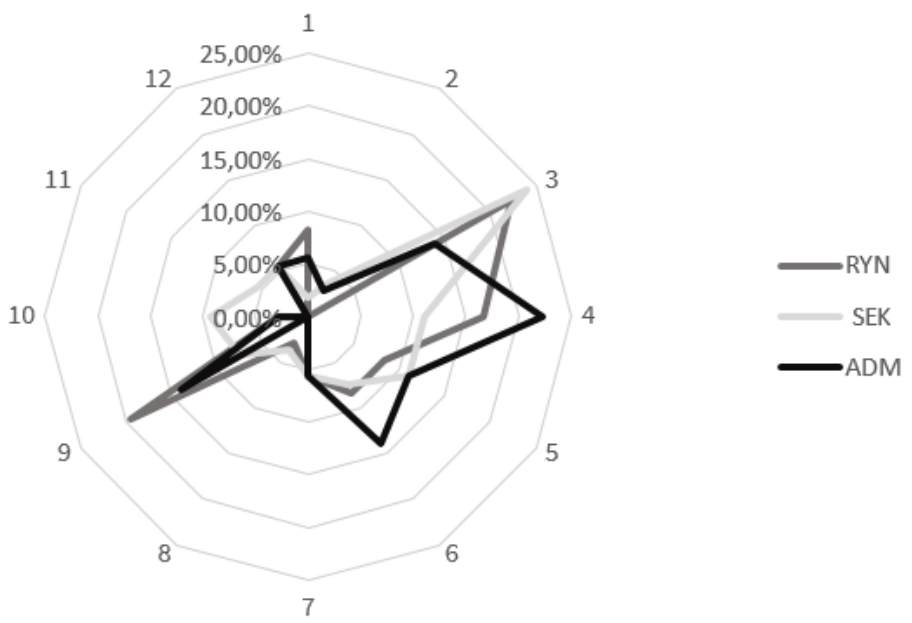

Rys. 5.16. Pożądane przez respondentów cechy idealnego partnera publicznego $(n=43)$

Rodzaj jednostek organizacyjnych: RYN - rynkowe, SEK - sektorowe, ADM - administracyjne; 1. Poważany; 2. Bogaty; 3. Uczciwy; 4. Lojalny; 5. Wiarygodny; 6. Odpowiedzialny; 7 . Z dużym doświadczeniem; 8. Otwarty; 9. O podobnych poglądach politycznych; 10. O szerokich kompetencjach; 11 . Sprawdzony we wcześniejszej współpracy; 12. Chętny do współpracy; 13 . Stabilny finansowo; 14. Stabilny politycznie; 15 . Przyjazna osobowość partnerów; 16. Inne czynniki, jakie?

Źródło: jak do rys. 5.1. 
Spośród grupy cech dotyczących zasobów intelektualnych wyróżniła się tylko jedna - $z$ dużym doświadczeniem - na którą wskazało $10 \%$ wszystkich respondentów, podczas gdy pozostałe miały jeszcze mniejszą liczbę wskazań. Oznacza to, że respondenci nie poszukują wśród partnerów publicznych intelektualnego wsparcia. Również cechy dotyczące zasobów finansowych nie wzbudziły większego zainteresowania respondentów. Tylko jedna z takich cech - stabilność finansowa została zauważona, zwłaszcza przez respondentów z departamentów sektorowych (9\%). Warto tu wspomnieć, że samorząd województwa otrzymuje z budżetów poszczególnych ministerstw dotacje celowe na realizację konkretnych zadań. Wśród odpowiedzi dodatkowych można zacytować przedstawiciela departamentu sektorowego (idealny partner to: patrzacy perspektywicznie, odznaczajacy się długofalowa wizja oraz taki, który ma świadomość dobra wspólnego).

Rozkład wskazań, dotyczących pożądanych cech idealnego partnera niepublicznego dla poszczególnych grup respondentów jest dość podobny. Wyniki zaprezentowano na rys. 5.17.

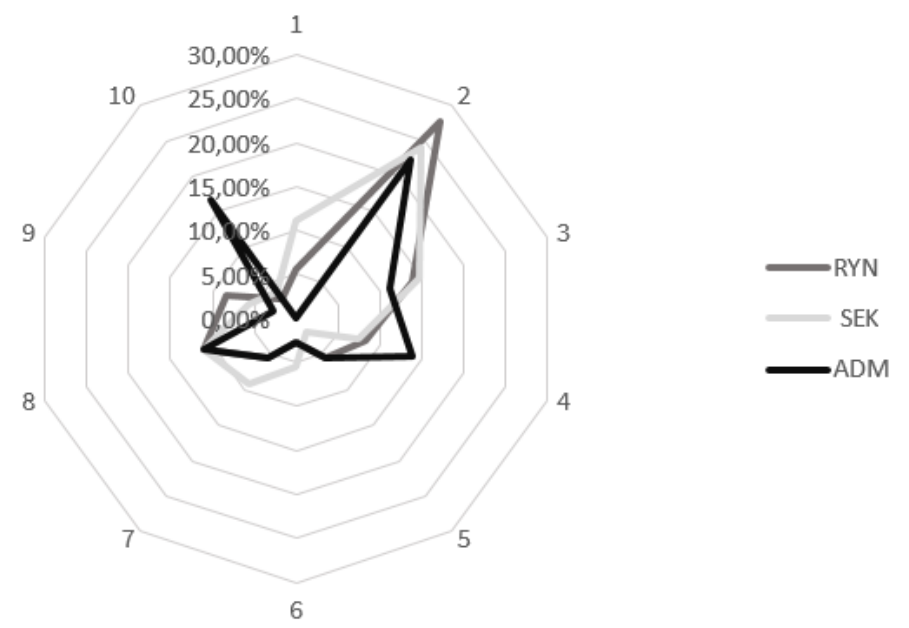

Rys. 5.17. Pożądane przez respondentów cechy idealnego partnera niepublicznego $(n=43)$

Rodzaj jednostek organizacyjnych: RYN - rynkowe, SEK - sektorowe, ADM - administracyjne; 1. Poważany; 2. Bogaty; 3. Uczciwy; 4. Lojalny; 5. Wiarygodny; 6. Odpowiedzialny; 7 . Z dużym doświadczeniem; 8. Otwarty; 9 . O podobnych poglądach politycznych; 10. O szerokich kompetencjach; 11 . Sprawdzony we wcześniejszej wspótpracy; 12 . Chętny do współpracy; 13. Stabilny

finansowo; 14. Stabilny politycznie; 15. Przyjazna osobowość partnerów; 16. Inne czynniki, jakie? 
Wśród cech idealnego partnera niepublicznego na czoło wysuwa się wiarygodność (23\% wskazań ogółem). W grupie departamentów rynkowych na cechę tę wskazało aż $28 \%$ menedżerów. Kolejne cechy wymieniane przez przedstawicieli tych departamentów to odpowiedzialność (14\%) oraz chęć do wspótpracy (11\%). Natomiast dla przedstawicieli departamentów administracyjnych liczy się głównie przyjazna osobowość partnerów (17\%), oraz duże doświadczenie (14\%). Przedstawiciel departamentu rynkowego zaproponował cechy dodatkowe, takie jak: kreatywność, dobre pomysty.

\subsection{Specyfika relacji organizacji terytorialnej na szczeblu regionu z lokalnymi JST}

Ze względu na opinie respondentów z urzędu marszałkowskiego pozyskane podczas badania pilotażowego zdecydowano się na zwrócenie większej uwagi na relację: organizacja terytorialna na szczeblu regionulokalne JST. Ta właśnie relacja wskazywana była jako szczególnie ważna w procesie prowadzenia polityki rozwoju na szczeblu województwa. Faktycznie, jeżeli chodzi o dystrybucję środków unijnych na poziomie RPO, to właśnie JST stanowią największą grupę beneficjentów. Lokalne samorządy to również najważniejsi dysponenci lokalnych, publicznych zasobów, które są wykorzystywane w procesie generowania rozwoju. Posiadają również bezpośredni bądź pośredni wpływ na innych interesariuszy instytucjonalnych regionu poprzez instrumenty polityki lokalnej, którą prowadzą na swoim terenie.

\subsubsection{Obszary merytoryczne we współdziałaniu samorządu województwa z lokalnymi JST}

Badani przedstawiciele departamentów urzędu marszałkowskiego zostali poproszeni o wskazanie obszarów kompetencyjnych samorządu województwa, które ich zdaniem wymagają zarządzania poprzez współdziałanie z lokalnymi JST. W pytaniu wymieniono dziesięć takich obszarów, pozostawiając respondentom możliwość uzupełnienia ich listy w pozycji - inne. Wyniki, z uwzględnieniem poszczególnych rodzajów departamentów, umieszczono na rys. 5.18.

Menedżerowie z departamentów rynkowych najczęściej wskazywali na takie obszary współdziałania, jak: pozyskiwanie środków europejskich, 
pozyskiwanie inwestorów zewnętrznych oraz rozwijanie infrastruktury (po 13\%). Należy podkreślić, że ten ostatni obszar był najczęściej wymieniany także przez respondentów z pozostałych rodzajów departamentów. Wśród wskazań ogółem relatywnie wysoką pozycję uzyskały również takie obszary, jak: polityka innowacyjna oraz ochrona środowiska. Jak pokazano na rys. 5.18, rozkłady odpowiedzi dla menedżerów każdego z trzech rodzajów departamentów są dość podobne.

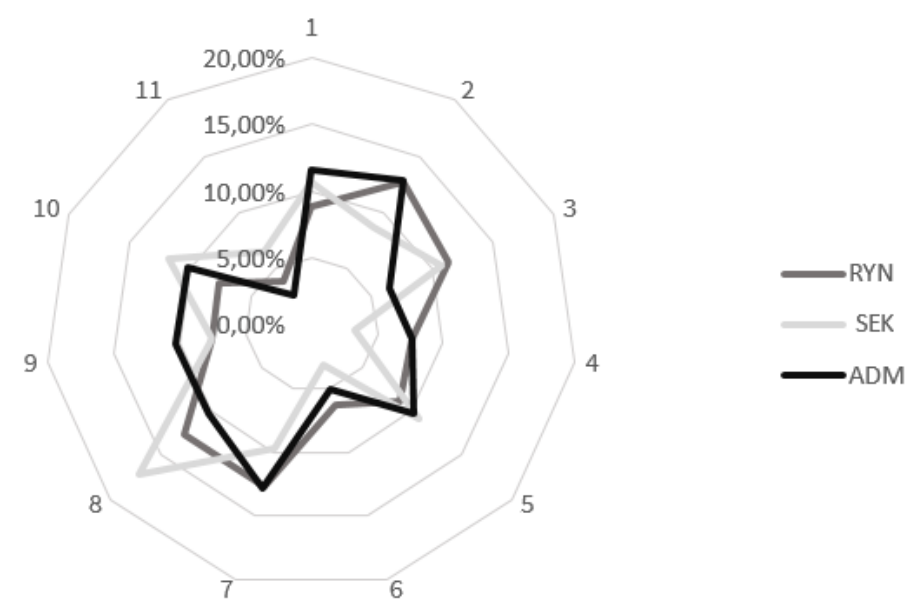

Rys. 5.18. Obszary merytoryczne współpracy OT na szczeblu regionu z lokalnymi JST $(n=43)$

Rodzaj jednostek organizacyjnych: RYN - rynkowe, SEK - sektorowe, ADM - administracyjne; 1. Rozwój przedsiębiorczości; 2. Pozyskiwanie środków europejskich; 3. Polityka innowacyjna; 4. Promocja gminy/powiatu; 5. Rozwój funkcji turystycznych; 6. Pozyskiwanie turystów; 7. Pozyskiwanie inwestorów zewnętrznych; 8. Rozwijanie infrastruktury; 9. Edukacja; 10. Ochrona środowiska; 11. Inne, jakie?

Źródto: jak do rys. 5.1.

Powyższym wynikom można przyjrzeć się również z perspektywy marketingu terytorialnego, poszukując merytorycznych obszarów współpracy nakierowanych na pozyskiwanie do terytorium mobilnych czynników wzrostu. Spróbujmy odpowiedzieć na pytanie, czy menedżerowie z OT na szczeblu regionu wyobrażają sobie współpracę z lokalnymi JST w zakresie działań marketingowych, mających na celu przyciąganie mobilnych inwestorów, turystów i studentów. Na standardowej liście odpowiedzi odnajdujemy kategorie korespondujące z tymi działaniami (odpowiedzi: 4, 5, 6, 7, 9). Przyglądając się natomiast wynikom badań, należy przyznać, że zarówno przyciąganie inwestorów, jak 
i turystów znajduje uznanie wśród respondentów, zwłaszcza z departamentów rynkowych i sektorowych. Problematyka pozyskiwania studentów została mniej wyeksponowana, chociaż pośrednio odpowiadają jej: edukacja (9) czy promocja gminy/powiatu (4). Należy też zaznaczyć, że odpowiedzi udzielają wszystkie lokalne JST, a najczęściej funkcje akademickie są zlokalizowane tylko w jednym ośrodku - stolicy województwa. Może to też oznaczać, że wspólne działania region-miasto w kierunku pozyskiwania studentów są rzadsze niż działania związane z pozyskiwaniem inwestorów i turystów.

\subsubsection{Ocena zaangażowania kierownictwa organizacji terytorialnej we współdziałanie z lokalnymi JST oraz ocena typowych propozycji usprawnień tego procesu}

Przedstawimy teraz rezultaty badań, dotyczące zaangażowania zarządu województwa we współdziałanie z lokalnymi JST (gminami i powiatami). Nie stanowi zaskoczenia fakt, że czterech na pięciu respondentów wskazało na bardzo wysoki lub wysoki stopień takiego zaangażowania, a ocena negatywna pojawiła się zaledwie raz. Przy interpretacji tych odpowiedzi należy wziąć pod uwagę fakt, że stojący na czele zarządu Marszałek Województwa jest bezpośrednim zwierzchnikiem badanych menedżerów (dyrektorów departamentów). $\mathrm{Z}$ tego względu należy przypuszczać, że ocena zwierzchnika przed nieznanym wcześniej ankieterem może skłaniać raczej do pozytywnych odpowiedzi. Niemniej jednak materiały wtórne, zebrane w poszczególnych urzędach marszałkowskich, świadczą o dużej aktywności organów wykonawczych badanych województw w relacjach z lokalnymi JST. Rozkład odpowiedzi pozyskanych od przedstawicieli trzech rodzajów departamentów nie wykazał istotnych odchyleń.

Kolejne pytania dotyczyły współpracy zarządu województwa, oddzielnie z gminami i powiatami z regionu. Należy podkreślić, że gminy w Polsce były do tej pory dużo słabiej zorganizowane niż powiaty. Te ostatnie posiadają struktury wojewódzkie zrzeszające wszystkie jednostki położone w jego granicach (Konwent Starostów). W przypadku gmin zwykle jest to dobrowolna organizacja je zrzeszająca, ale zawsze przynajmniej część z nich pozostaje poza jej zasięgiem. Istnienie podmiotu integrującego gminy czy powiaty jest niezwykle ważne z perspektywy władz województwa samorządowego, bowiem pozwala na bardziej uporządkowany dialog pomiędzy szczeblami samorządu terytorialnego.

Zapytano więc respondentów, jaki jest w ich ocenie stopień zaangażowania zarządu województwa we współdziałanie z największym związkiem gmin w województwie. Rozkład odpowiedzi zaprezentowano na 
rys. 5.19. Pytanie zadawane było w kontekście istnienia i działalności następujących struktur: województwo łódzkie (Stowarzyszenie Gmin i Powiatów Województwa Łódzkiego), województwo małopolskie (Stowarzyszenie Gmin i Powiatów Małopolski), województwo świętokrzyskie (Stowarzyszenie Miast i Gmin Województwa Świętokrzyskiego), województwo wielkopolskie (Związek Gmin i Powiatów Województwa Wielkopolskiego).

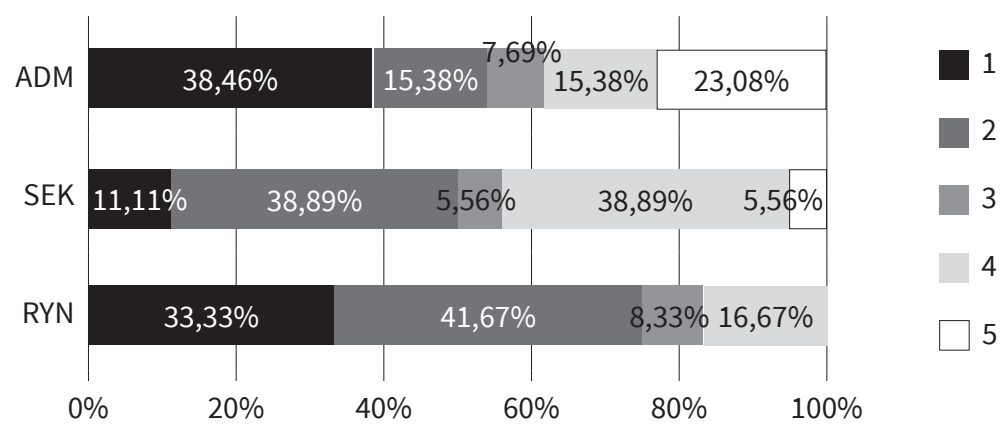

Rys. 5.19. Stopień zaangażowania zarządu województwa we współdziałanie z największym związkiem gmin w regionie w ocenie menedżerów OT $(n=43)$

1 - bardzo duży, 2 - duży, 3 - średni, 4 -trudno powiedzieć, 5 - brak danych.

Źródto: jak do rys. 5.1.

Niemal 1/4 respondentów wskazała na odpowiedź „0” - trudno powiedzieć. Mogła mieć na to wpływ niepełna wiedza dyrektorów o poczynaniach zarządu województwa. W innym wariancie respondenci mogli dostrzegać pewne słabości współpracy, ale nie chcieli ich ujawniać $\mathrm{w}$ bezpośredniej rozmowie $\mathrm{z}$ ankieterem. Blisko $60 \%$ respondentów odpowiedziało: $w$ bardzo dużym lub dużym stopniu. W przypadku departamentów rynkowych aż 75\% odpowiadających udzieliło właśnie takich odpowiedzi. Może to świadczyć również o tym, że menedżerowie tych departamentów lepiej rozumieją rolę takiej współpracy i tym dokładniej przyglądają się związkom gmin czy nawet uczestniczą w ich pracach.

W odniesieniu do współpracy zarządu województwa ze stowarzyszeniem powiatów (Konwentem Powiatów) ocena wypadła jeszcze bardziej pozytywnie. W każdym rodzaju departamentów odpowiedzi $w$ bardzo dużym stopniu były wyższe niż $\mathrm{w}$ przypadku gmin. Wyniki zaprezentowano na rys. 5.20. 


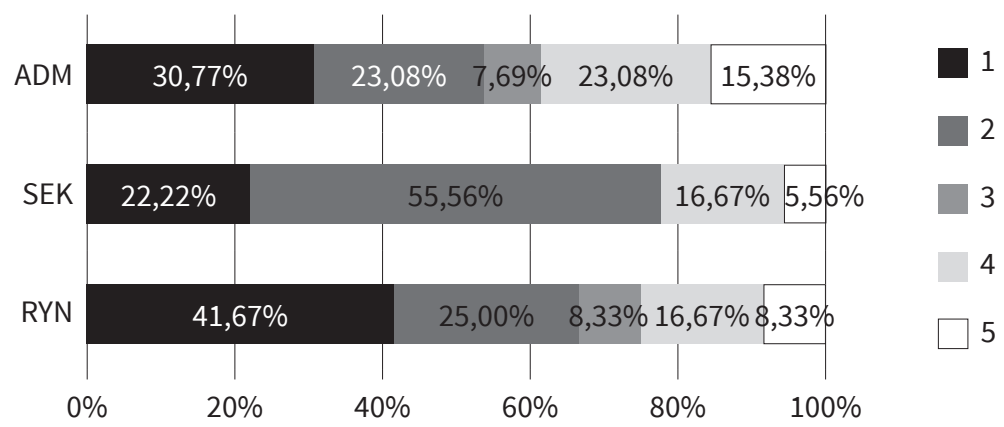

Rys. 5.20. Stopień zaangażowania zarządu województwa we współdziałanie ze stowarzyszeniem powiatów w ocenie menedżerów OT $(n=43)$

1 - bardzo duży, 2 - duży, 3 - średni, 4 -trudno powiedzieć, 5 - brak danych.

Źródto: jak do rys. 5.1.

Łącznie aż $67 \%$ badanych oceniło taką współpracę jako bardzo dobrą lub dobrą. Podobnie jak w przypadku relacji zarządu województwa z gminami, również relacja zarządu z powiatami została najwyżej oceniona przez menedżerów $z$ departamentów rynkowych. Fakt odnotowania mniejszej liczby odpowiedzi typu: trudno powiedzieć może świadczyć o większej rozpoznawalności tej struktury organizacyjnej wśród dyrektorów departamentów urzędu marszałkowskiego.

\subsubsection{Współpraca zarządu województwa z podmiotami instytucjonalnymi w ocenie interesariuszy instytucjonalnych}

Postawy zarządu województwa wobec współdziałania z podmiotami instytucjonalnymi regionu ocenili również respondenci reprezentujący interesariuszy instytucjonalnych. Ich odpowiedzi były dużo bardziej konkretne niż poprzednio. Niemal nie wystąpiły odpowiedzi: trudno powiedzieć. Najbardziej zgodni $\mathrm{w}$ odpowiedziach byli przedstawiciele uczelni wyższych. Wszyscy ocenili zaangażowanie zarządu we współpracę w stopniu bardzo dużym i dużym (odpowiednio 64\% i 46\%). Podobną zgodność wykazali respondenci z JST, choć tu dominowała odpowiedź $w$ dużym stopniu. Pośród badanych rodzajów interesariuszy instytucjonalnych najmniej zgodni byli przedstawiciele organizacji okołobiznesowych. W ich przypadku pojawiły się wszystkie możliwe odpowiedzi - również takie: $w$ małym czy bardzo małym stopniu. Odpowiedzi respondentów zaprezentowane zostały na rys. 5.21. 


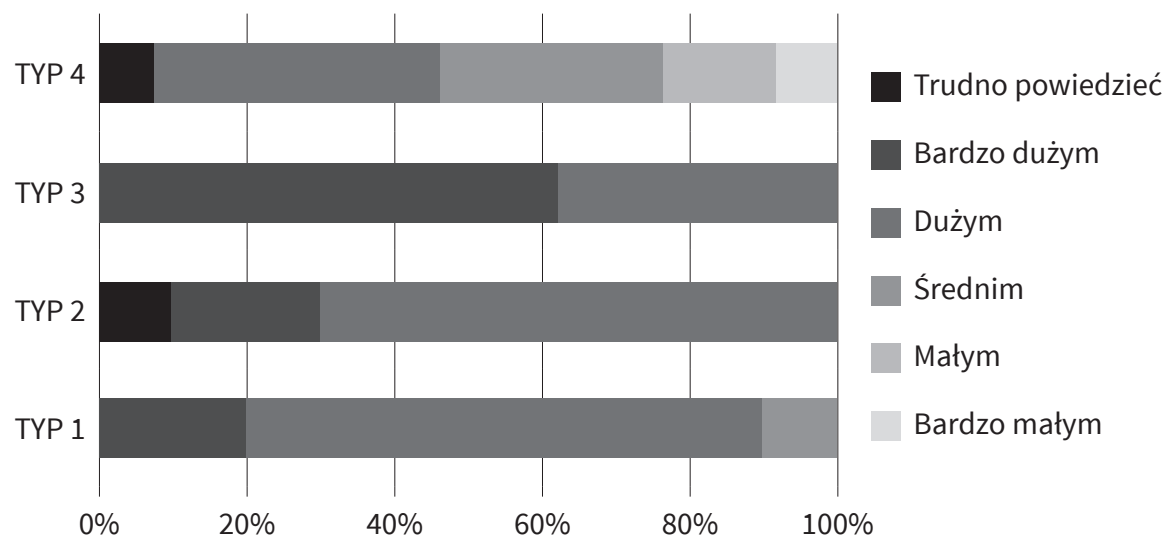

Rys. 5.21. Stopień zaangażowania zarządu województwa we współpracę z podmiotami instytucjonalnymi z regionu w ocenie interesariuszy instytucjonalnych $(n=42)$

Typy badanych podmiotów: TYP 1 - lokalne JST, TYP 2 - administracja państwowa, TYP 3 uczelnie wyższe, TYP 4 - organizacje okołobiznesowe.

Źródło: jak na rys. 5.1.

Interesariusze instytucjonalni proszeni byli również o wskazanie obszarów realizowanej obecnie współpracy z jednostkami zarządu województwa. Najczęściej wskazywali kolejno takie, jak: pozyskiwanie środków europejskich (88\% wskazań), polityka innowacyjna (67\%), rozwój przedsiębiorczości (74\%), edukacja publiczna (74\%) oraz rozwijanie infrastruktury edukacyjnej (67\%). Warto zauważyć, że wymienione obszary stanowią podstawowe priorytety unijnego wsparcia dla naszego kraju. Dodajmy, że dystrybucji środków unijnych dokonuje właśnie samorząd województwa. Szczegółowe wyniki badań z uwzględnieniem czterech rodzajów interesariuszy przedstawiono na rys. 5.22.

Na rys. 5.22 pokazano, że pola obszarów współpracy są największe dla uczelni wyższych oraz samorządów lokalnych. Przedstawiciele uczelni wyższych (TYP 3) byli jednomyślni co do takich obszarów współpracy, jak: pozyskiwanie środków europejskich, rozwój przedsiębiorczości, polityka innowacyjna (po 100\% wskazań). Niewiele mniej wskazań otrzymały takie obszary, jak: promocja regionu czy popularyzacja kultury $i$ jej rozwój (po 88\%). Lokalne JST (TYP 1) wskazały w 100\% takie obszary współpracy, jak: pozyskiwanie środków europejskich oraz rozwijanie infrastruktury drogowej i ochrony środowiska. Są to typowe obszary związane z rolą samorządu województwa w dystrybucji środków unijnych. Nieco mniej wskazań (80\%) otrzymały takie obszary, jak: promocja regionu, rozwój funkcji turystycznych regionu oraz rozwijanie infrastruktury edukacyjnej. 


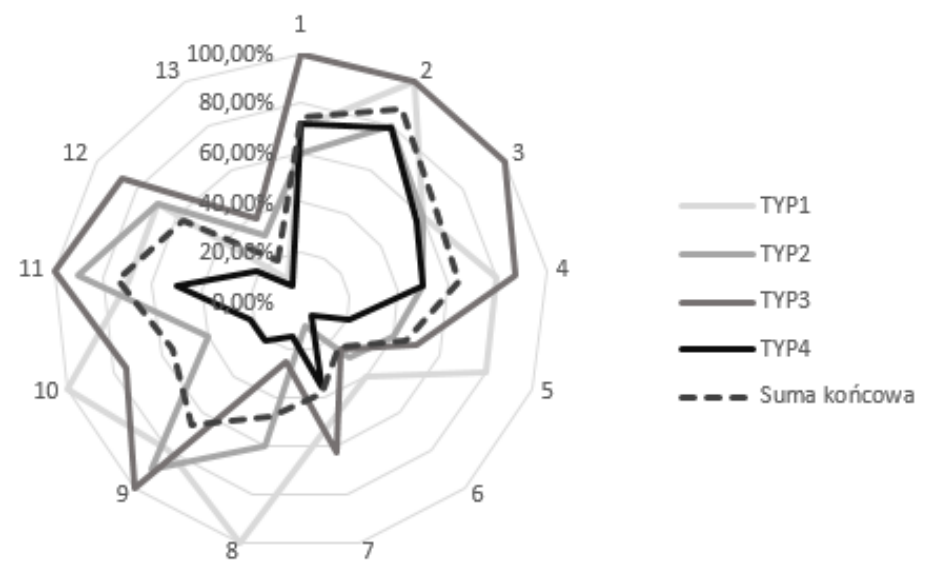

Rys. 5.22. Obszary współpracy z OT na szczeblu regionu w opinii interesariuszy instytucjonalnych $(n=42)$

Typy badanych podmiotów: TYP 1 - lokalne JST, TYP 2 - administracja państwowa, TYP 3 - uczelnie wyższe, TYP 4 - organizacje okołobiznesowe; 1. Rozwój przedsiębiorczości; 2. Pozyskiwanie środków europejskich; 3. Polityka innowacyjna; 4. Promocja regionu; 5. Rozwój funkcji turystycznych regionu; 6. Pozyskiwanie turystów dla regionu; 7. Pozyskiwanie inwestorów zewnętrznych; 8. Rozwijanie infrastruktury drogowej; 9. Rozwijanie infrastruktury edukacyjnej; 10. Rozwijanie infrastruktury ochrony środowiska; 11. Edukacja publiczna; 12. Popularyzacja kultury i jej rozwój; 13. Inne, jakie?

Źródto: jak do rys. 5.1.

Kontrastuje to wyraźnie z obszarami współpracy administracji państwowej (TYP 2), której respondenci wskazywali najczęściej na: rozwijanie infrastruktury edukacyjnej czy edukację publiczną (po 90\% wskazań) oraz pozyskiwanie środków europejskich (80\%) czy popularyzacje kultury i jej rozwój (70\%). W przypadku tej grupy należy jednak być ostrożnym przy interpretacji uzyskanych wskazań, bowiem grupa respondentów była dość niejednolita. Współpraca organizacji okołobiznesowych (TYP 4) koncentrowała się głównie na takich obszarach, jak: pozyskiwanie środków europejskich (88\%), edukacja publiczna (74\%), polityka innowacyjna oraz rozwijanie infrastruktury edukacyjnej (po 67\%). Warto dodać, że respondenci rzadko wymieniali takie obszary, jak: promocja regionu, rozwój funkcji turystycznych regionu, pozyskiwanie turystów czy rozwijanie infrastruktury drogowej.

$\mathrm{W}$ badaniu pytano również respondentów o obszary, w których nie współpracują z urzędem marszałkowskim, ale w zakresie których chcieliby podjąć współpracę. Respondenci relatywnie rzadko wskazywali obszary, w których nie współpracują z urzędem marszałkowskim. Spośród 
tych wskazań najczęściej pojawiały się takie, jak: pozyskiwanie inwestorów zewnętrznych (33\%), pozyskiwanie turystów dla regionu (31\%), promocja regionu (21\%). Spośród wyodrębnionych typów interesariuszy instytucjonalnych zdecydowanie najszerzej nakreślili potencjalne obszary współpracy przedstawiciele organizacji okołobiznesowych (TYP 4), najwęziej natomiast - administracja państwowa. W przypadku organizacji okołobiznesowych wskazywano na takie pożądane przez nich obszary, jak: pozyskiwanie inwestorów zewnętrznych (50\% wskazań), promocja regionu (43\%), polityka innowacyjna, rozwijanie infrastruktury innowacyjnej (po 36\%).

Prezentowane na rys 5.23 wyniki pokazują, że organizacje okołobiznesowe są tym partnerem organizacji terytorialnych, który jest otwarty na współpracę oraz ze względu na posiadany potencjał i zaangażowanie w tzw. działania miękkie może przyczynić się do rozwoju terytorium.

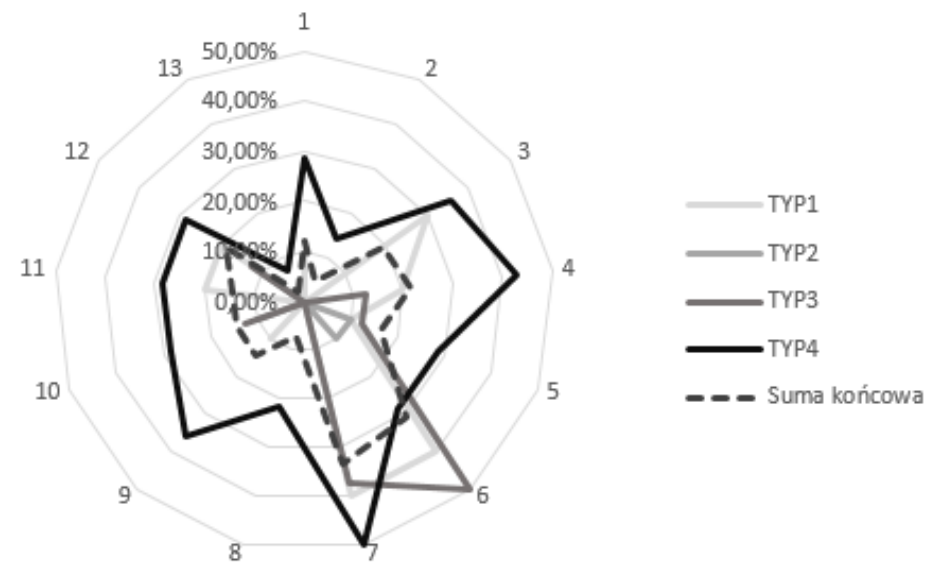

Rys. 5.23. Pożądane obszary współpracy z OT z perspektywy interesariuszy instytucjonalnych $(n=42)$

Typy badanych podmiotów: TYP 1 - lokalne JST, TYP 2 - administracja państwowa, TYP 3 - uczelnie wyższe, TYP 4 - organizacje okołobiznesowe; 1. Rozwój przedsiębiorczości; 2. Pozyskiwanie środków europejskich; 3. Polityka innowacyjna; 4. Promocja regionu; 5. Rozwój funkcji turystycznych regionu; 6. Pozyskiwanie turystów dla regionu; 7. Pozyskiwanie inwestorów zewnętrznych; 8. Rozwijanie infrastruktury drogowej; 9. Rozwijanie infrastruktury edukacyjnej; 10. Rozwijanie infrastruktury ochrony środowiska; 11. Edukacja publiczna; 12. Popularyzacja kultury i jej rozwój; 13. Inne, jakie?

Źródło: jak do rys. 5.1. 
W przedstawianych badaniach interesariusze instytucjonalni wyrazili ponadto swoją opinię na temat utrudnień, jakie napotykają we współpracy z organizacją terytorialną. Respondenci najczęściej doszukiwali się utrudnień w przepisach prawnych (nieczytelne reguly wspótpracy - 21\%, przepisy prawne ograniczajace wspótprace - 15\%). Bardzo rzadko wskazywano na niedoskonałości własnej organizacji jako bariery do współpracy, a także rzadko - na utrudnienia leżące po stronie organizacji terytorialnej. Szczegółowe informacje na ten temat ukazano na rys. 5.24.

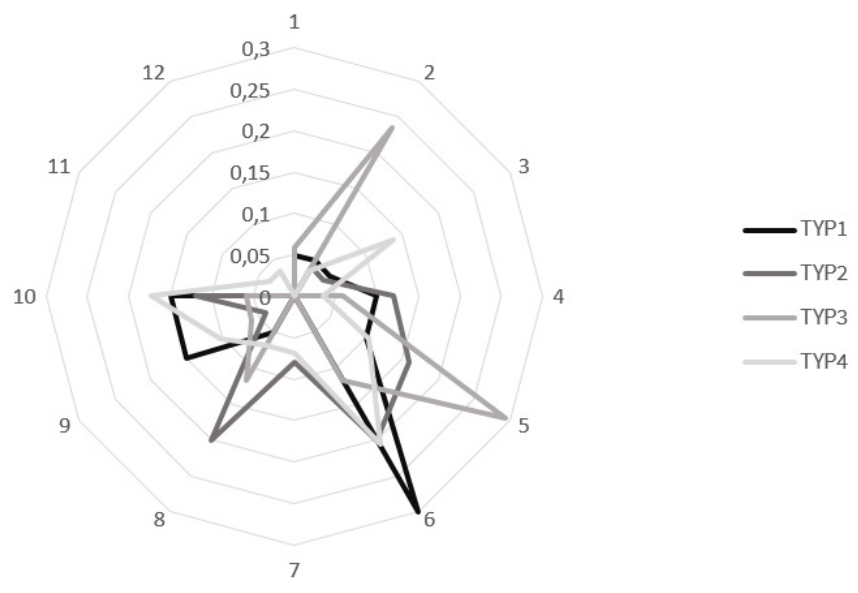

Rys. 5.24. Czynniki utrudniające współpracę z organizacją terytorialną w opinii interesariuszy instytucjonalnych $(\mathrm{n}=42)$

Typy badanych podmiotów: TYP 1 - lokalne JST, TYP 2 - administracja państwowa, TYP 3 - uczelnie wyższe, TYP 4 - organizacje okołobiznesowe; 1. Niechęć Pani/Pana instytucji do współpracy z organami samorządu regionalnego; 2 . Słabe przygotowanie pracowników Pana/ Pani instytucji do nawiązywania i prowadzenia zewnętrznej współpracy; 3. Brak „zielonego światła” ze strony organów nadrzędnych do nawiązywania i prowadzenia współpracy z podmiotami zewnętrznymi; 4. Niezgodność opcji politycznej (osoby reprezentujące instytucję - potencjalnego partnera - mają odmienne przekonania polityczne niż opcja reprezentowana przez samorząd regionu); 5. Przepisy prawne ograniczające współpracę (np. przepisy podatkowe); 6. Nieczytelne reguły współpracy (na styku: Pana/Pani instytucja - samorząd regionu); 7. Niechęć samorządu regionu do podejmowania współpracy z Pana/Pani instytucją; 8. Roszczeniowe podejście samorządu regionu do współpracy (np. oczekiwanie od partnera znacznego zaangażowania finansowego); 9. Cechy osobowościowe osób reprezentujących samorząd regionu; 10. Inne czynniki, jakie? (proszę wpisać).

Źródło: jak do rys. 5.1.

Należy podkreślić, że spośród czterech badanych typów interesariuszy jedynie uczelnie wyższe wykazały największą zgodność w formułowaniu utrudnień do współpracy. Najważniejsze ich zdaniem utrudnienia 
to: przepisy prawne ograniczajace wspótpracę (80\%), słabe przygotowanie pracowników uczelni do nawiązywania i prowadzenia zewnętrznej wspótpracy (57\%) oraz nieczytelne reguly wspólpracy na styku: uczelnia-samorzad regionu $(40 \%)$. W pozostałych grupach respondentów nie odnotowano tak jednoznacznych odpowiedzi.

\subsubsection{Postawy menedżerów publicznych wobec propozycji usprawniania procesu współdziałania region-lokalne JST}

Konkretne propozycje usprawnień zidentyfikowanych podczas badania pilotażowego (numery 1-7) poddano ocenie menedżerów z urzędów marszałkowskich. Wyniki zaprezentowano na rys. 5.25. Przyjrzyjmy się im z perspektywy wskazań menedżerów reprezentujących departamenty rynkowe, zwłaszcza w obszarach, gdzie kontrastują wyraźnie ze wskazaniami respondentów z jednostek sektorowych i administracyjnych.

Propozycja usprawnienia procesu współdziałania na linii region-lokalne JST w postaci: powołania zespołów zadaniowych przy marszat$k u$ województwa ( $w$ obszarach merytorycznych) składających się m.in. $z$ przedstawicieli samorzadów lokalnych została wskazana praktycznie przez wszystkich respondentów z departamentów rynkowych. Jest to o tyle istotne, że menedżerowie $\mathrm{z}$ departamentów sektorowych i administracyjnych wybierali ją znacznie rzadziej. Przykład ten może sugerować, że menedżerowie rynkowi są zwolennikami modelu governance, czyli współrządzenia publicznego w regionie, przy istotnym udziale lokalnych JST $\mathrm{w}$ tym procesie.

Szefowie departamentów rynkowych opowiedzieli się również za propozycją, aby: powiazania samorzadu regionalnego przybierały bardziej nieformalny charakter (15\% wskazań). Propozycja ta mocno kontrastuje z opiniami menedżerów z departamentów sektorowych i administracyjnych, którzy sporadycznie wskazywali na jej zasadność (4\% wskazań). Warto podkreślić, że menedżerowie z departamentów administracyjnych zadeklarowali pogląd przeciwny: powiązania samorzadu regionalnego z samorządami lokalnymi powinny przybierać bardziej formalny charakter (17\% wszystkich wskazań).

Najwięcej wskazań wśród respondentów z departamentów sektorowych i administracyjnych dotyczyło propozycji: poszczególne departamenty urzędu marszałkowskiego powinny w praktycznych działaniach więcej uwagi poświęcić inicjowaniu i prowadzeniu wspólnych przedsięwzięć $z$ samorzadami lokalnymi. Propozycja ta uzyskała odpowiednio: $24 \%$ i $26 \%$ wszystkich udzielonych przez nich odpowiedzi. Warto podkreślić, 
że menedżerowie z jednostek rynkowych znacznie rzadziej wskazywali na tę propozycję usprawnień. Zdaniem autora jest to spowodowane tym, że posiadają oni szerszą wiedzę na temat dotychczasowej współpracy OT na szczeblu regionu w tym zakresie i kwestionują podejmowanie nowych relacji, w sytuacji gdy istniejące relacje są wystarczające. Brak wskazań na powyższą propozycję może również wynikać z obserwowanej przez respondentów, małej skuteczności tego rodzaju działań.

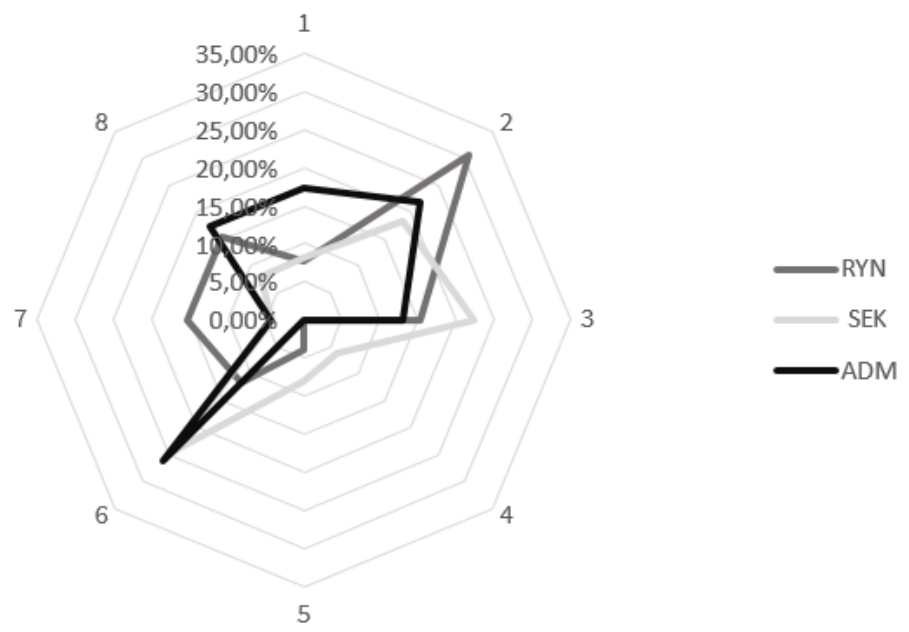

Rys. 5.25. Ocena propozycji usprawnień współdziałania region-lokalne JST ( $n=43$ )

Rodzaj jednostek organizacyjnych: RYN - rynkowe, SEK - sektorowe, ADM - administracyjne; 1. Powiązania samorządu regionu z samorządami lokalnymi powinny przybierać bardziej formalny charakter; 2 . Powołanie zespołów zadaniowych przy marszałku województwa (w obszarach merytorycznych) składających się m.in. z przedstawicieli samorządów lokalnych; 3. Przygotowanie i realizacja cyklu seminariów dla samorządowców z regionu mających na celu kształtowanie świadomości władz lokalnych na temat korzyści współdziałania jednostek samorządu terytorialnego; 4. Marszałek województwa powinien obejmować patronatem więcej inicjatyw lokalnych; 5. Przedstawiciele zarządu województwa powinni częściej uczestniczyć w wydarzeniach lokalnych na terenie województwa; 6 . Poszczególne departamenty urzędu marszałkowskiego powinny w praktycznych działaniach więcej uwagi poświęcić inicjowaniu i prowadzeniu wspólnych przedsięwzięć z samorządami lokalnymi; 7. Powiązania samorządu regionalnego z samorządami lokalnymi powinny przybierać bardziej nieformalny charakter; 8. Inne propozycje, jakie?

Źródło: jak do rys. 5.1.

Uzyskane odpowiedzi prowadzą do wniosku, że stosunek poszczególnych grup menedżerów publicznych do międzyorganizacyjnego współdziałania jest zróżnicowany. Jedynie menedżerowie z departamentów rynkowych są zwolennikami nieformalnych form współdziałania regio- 
nu z lokalnymi JST. Popierają oni m.in. powoływanie zespołów zadaniowych przy udziale przedstawicieli samorządów lokalnych. Natomiast menedżerowie $\mathrm{z}$ departamentów sektorowych nie podzielają takiego rozwiązania, a nawet postulują wzmocnienie formalnych powiązań $\mathrm{z}$ interesariuszami instytucjonalnymi regionu.

\subsection{Podsumowanie i interpretacja wyników badań}

Przyjęte wcześniej założenie, że samorządowy region będziemy traktować jako metaforę przedsiębiorstwa, pozwala traktować go jako przestrzeń dla wykorzystywania koncepcji marketingowych, w tym przede wszystkim marketingu interesariuszy. Zgodnie z tą koncepcją omawiane wcześniej relacje międzyorganizacyjne mogą służyć przyciąganiu do regionu mobilnych czynników wzrostu, których nośnikami są inwestorzy, turyści oraz studenci. Kilkadziesiąt wywiadów bezpośrednich, wizyty w urzędach marszałkowskich czterech województw oraz spotkania z szefami organizacji publicznych, prywatnych i społecznych, będących dla nich interesariuszami instytucjonalnymi, pozwoliły zrealizować nakreślone wcześniej cele. Udało się opisać specyfikę relacyjną rynkowych jednostek organizacyjnych OT wobec pozostałych grup (jednostek sektorowych i administracyjnych) oraz zidentyfikować i scharakteryzować najważniejsze dla budowania konkurencyjności regionu rynki interesariuszy instytucjonalnych (C1a, C2a). Pozwoliło to na późniejsze zawężenie badań i uzasadnienie podjętych $\mathrm{w}$ tym kontekście decyzji. Wybrano bowiem jedną $\mathrm{z}$ relacji i skoncentrowano się na jej opisie w kontekście realizacji procesów pozyskiwania do regionu mobilnych czynników wzrostu.

Respondenci z departamentów rynkowych, będących w istocie jednostkami realizującymi funkcje marketingowe w badanych OT, częściej wskazywali w swoich wypowiedziach na ważną rolę współpracy zewnętrznej urzędu marszałkowskiego niż robili to przedstawiciele departamentów administracyjnych. Natomiast współpraca wewnętrzna pomiędzy departamentami w urzędzie marszałkowskim została oceniona mniej pozytywnie, chociaż jej oceny były zróżnicowane. Najsurowiej oceniają ją przedstawiciele departamentów rynkowych, którzy, będąc generalnie bardziej otwarci, mają największe oczekiwania w tym zakresie. Najmniej krytycznych pod tym względem ocen zgłaszali kierujący departamentami administracyjnymi, którzy odpowiadają za koordynację tego rodzaju współpracy. Można przypuszczać, że nie chcą w ten sposób odsłaniać swoich niekompetencji. 
Badania wykazały, że łącznie menedżerowie publiczni na szczeblu regionu chętniej współpracują z organizacjami publicznymi niż prywatnymi i społecznymi. Nie odnosi się to jednak do wszystkich rodzajów departamentów. Menedżerowie stojący na czele departamentów rynkowych chętniej współpracują z interesariuszami niepublicznymi niż publicznymi. W tej pierwszej grupie, jako partnerów do współpracy, wskazywali głównie prywatne ośrodki badawczo-rozwojowe, niepubliczne szkoły wyższe oraz samorządy gospodarcze. Natomiast wśród interesariuszy publicznych jako ważnych partnerów rynkowych jednostek organizacyjnych OT uznano: lokalne JST z terenu województwa, centralną administrację rządową oraz publiczne szkoły wyższe (C4a).

Prezentowane wyżej rezultaty badań wskazują na pozytywną weryfikację hipotez $\mathrm{H} 1 \mathrm{a}$ oraz $\mathrm{H} 2 \mathrm{a}$, odnoszących się do menedżerów publicznych stojących na czele departamentów rynkowych. W istocie wykazano, że kompetencje relacyjne badanych są zróżnicowane, a czynnik rodzaju departamentu, którym kierują, jest powiązany z ich postawami. Przy czym tzw. menedżerowie rynkowi deklarowali posiadanie wyższych kompetencji relacyjnych (H1a). Natomiast jeżeli chodzi o otwartość na współpracę z interesariuszami instytucjonalnymi, to potwierdzono, że menedżerowie publiczni częściej deklarowali chęć współpracy z podmiotami niepublicznymi niż pozostali respondenci, stojący na czele departamentów sektorowych i administracyjnych (H2a).

Pozytywnie zweryfikowano również hipotezę H3a, mówiącą o tym, że podstawowym czynnikiem skłaniającym OT do współpracy z interesariuszami instytucjonalnymi jest możliwość korzystania z pozostających w ich dyspozycji zasobów dla realizacji postawionych przed samorządem zadań. Generalnie, zarówno menedżerowie publiczni OT, jak i interesariusze instytucjonalni deklarowali w swoich wypowiedziach niemal pełną otwartość na współpracę zewnętrzną. Wśród czynników skłaniających do współpracy menedżerowie publiczni wymieniali najczęściej: większe możliwości realizacji zadań (28\%), korzystanie z doświadczeń wiedzy i kompetencji innych podmiotów (24\%) oraz pozyskanie zewnętrznych środków (12\%).

Przyjrzyjmy się nieco dokładniej relacjom urzędu marszałkowskiego z jednym z najważniejszych jego partnerów, czyli lokalnymi JST. Biorąc pod uwagę merytoryczny zakres relacji region-lokalne JST, można zauważyć, że respondenci z urzędu marszałkowskiego wskazywali na działania wpisujące się w koncepcję marketingu relacji, które najczęściej dotyczyły pozyskiwania inwestorów zewnętrznych. Do kluczowych korzyści ze współdziałania $\mathrm{z}$ interesariuszami instytucjonalnymi regionu menedżerowie z departamentów rynkowych zaliczyli: większe możliwości realizacji postawionych przed samorządem zadań oraz chęć skorzystania $z$ doświadczenia, wiedzy, kompetencji partnerów. Natomiast jako najważniejszą, 
pożądaną cechę potencjalnego partnera wskazywano jego wiarygodność. Powyższe rozważania wskazują jednoznacznie na wyższe kompetencje relacyjne departamentów rynkowych oraz relatywnie większą ich otwartość na współpracę z interesariuszami instytucjonalnymi, zwłaszcza niepublicznymi (C3a). Prezentowane w tym rozdziale rezultaty badań, a także wiedza na ten temat uzyskana $\mathrm{z}$ innych źródeł, pozwoliły autorowi dokonać następującej klasyfikacji rynków interesariuszy instytucjonalnych dla samorządowego regionu: rynek lokalnych JST, rynek instytucji naukowych i edukacyjnych (zwłaszcza na poziomie wyższym i zawodowym), rynek legislatorów i kontrolerów, rynek organizacji pozarządowych (NGO), rynek pracowników (jako dysponentów zasobów pracy), rynek biznesowy. Rynki te umieszczono na rys. 5.26 (C5a). Celowo mocniej zaznaczono takie, jak: lokalne JST, naukę i edukację oraz legislatorów i kontrolerów, bowiem badani menedżerowie z urzędów marszałkowskich deklarowali bliższe relacje z wchodzącymi w ich skład interesariuszami niż z pozostałymi, na których dominują podmioty z sektora prywatnego i społecznego. Niżej dokonamy krótkiej charakterystyki poszczególnych rynków oraz uzasadnimy ich znaczenie dla budowania konkurencyjności regionu.

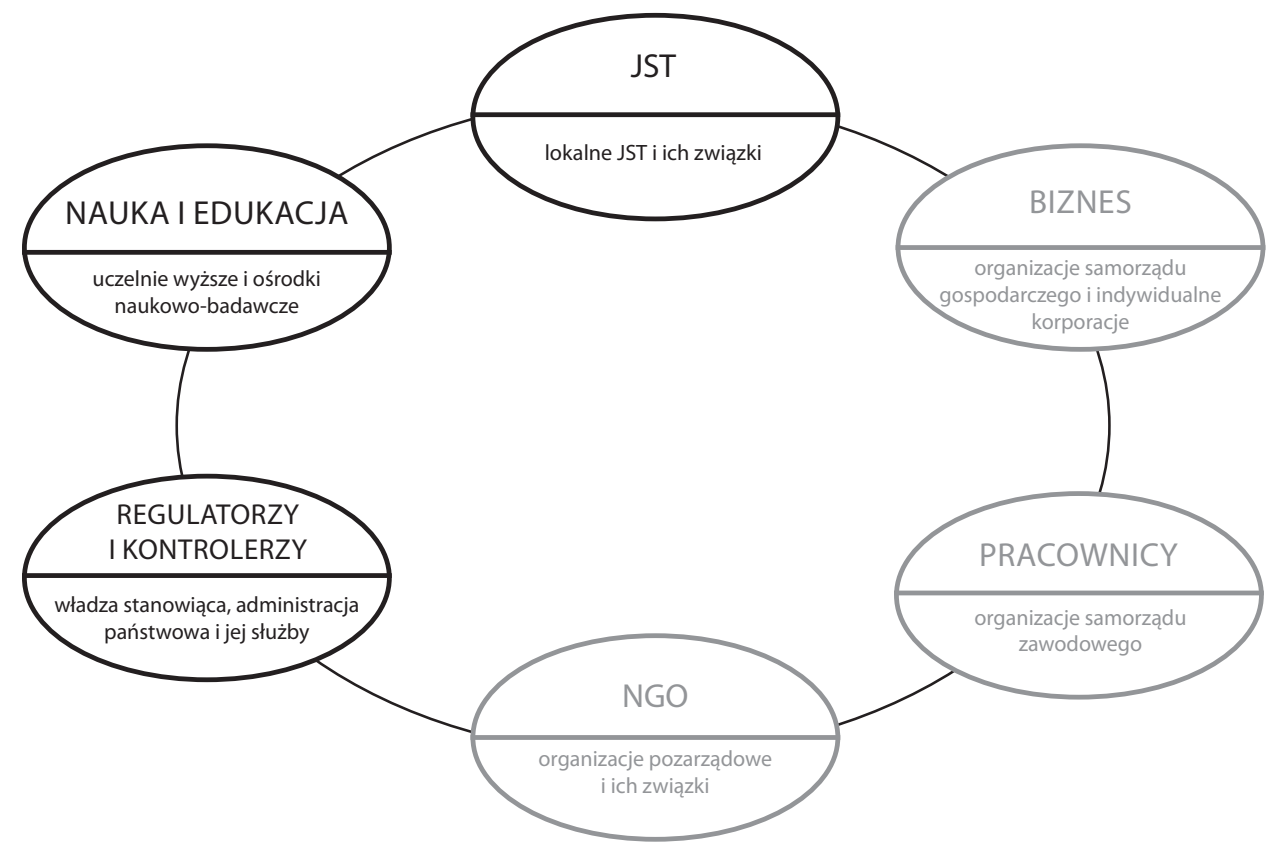

Rys. 5.26. Model sześciu rynków dla OT na szczeblu województwa samorządowego w kontekście prowadzenia polityki rozwoju

Źródło: opracowanie własne. 
Lokalne JST. Jest to rynek kluczowy dla budowania konkurencyjności zewnętrznej województwa. Jest to średnio nieco ponad 150 gmin i około 20 powiatów w każdym województwie. W przypadku powiatów ich liczba nie jest zbyt duża, co pozwoliło na zorganizowanie uporządkowanego dialogu pomiędzy strukturami wojewódzkimi a Konwentem Starostów. Gminy natomiast nie potrafiły się w odpowiedni sposób porozumieć i choć w większości województw działają związki gmin czy miast, to nigdzie nie stanowią one całościowej reprezentacji wszystkich gmin i miast regionu. W tej sytuacji większe jednostki lokalne (miasta) budują indywidualne relacje $\mathrm{z}$ regionem zarówno na poziomie politycznym, jak i operacyjnym. Szczególnym przypadkiem będzie tu relacja regionmiasto, będące stolicą regionu. $\mathrm{Z}$ perspektywy regionu współdziałanie z lokalnymi JST daje większe możliwości realizacji zadań postawionych przed samorządem regionu. Współpracę na tej linii utrudniają przepisy prawne oraz roszczeniowe podejście partnerów. Natomiast z perspektywy lokalnych JST współpraca z regionem motywowana jest chęcią pozyskania środków, będących w dyspozycji samorządu regionu oraz większą możliwością realizacji postawionych przed nimi zadań.

Nauka i edukacja. Jest to rynek zdominowany przez organizacje publiczne. W jego skład wchodzą szkoły wyższe oraz instytuty badawcze. W niektórych regionach zwłaszcza środowisko publicznych szkół wyższych integruje się, tworząc rady czy zespoły dla wzmocnienia własnej pozycji wobec samorządu regionu. Często jednak liczba podmiotów na takim rynku jest tak niewielka, że ich relacje z samorządem regionu kształtowane są w sposób indywidualny. Należy zaznaczyć, że autor zdecydował się nie różnicować szkół wyższych na publiczne i niepubliczne, jak to miało miejsce podczas prowadzonego badania. Odpowiedzi obu tych kategorii respondentów nie wykazały bowiem istotnych różnic. $\mathrm{Z}$ perspektywy regionu relacje $\mathrm{z}$ interesariuszami z rynku „nauka i edukacja" przynoszą większe możliwości realizacji postawionych przed samorządem zadań oraz możliwości skorzystania z doświadczeń, wiedzy i kompetencji znajdujących się na tym rynku podmiotów. Dodać można, że przepisy administracyjne nie sprzyjają rozwojowi relacji regionu $\mathrm{z}$ tą grupą interesariuszy.

Rynek „nauka i edukacja” nabiera w ostatnich latach znaczenia z powodu rosnącej popularności koncepcji budowania konkurencyjności regionu w oparciu o strategie innowacji. Podmioty wchodzące w skład tego rynku zdają sobie sprawę z pierwszoplanowej roli, jaką pełnią w zakresie podnoszenia poziomu innowacyjności województwa, a sama polityka innowacyjności staje się obecnie domeną kompetencji samorządowego regionu. Regiony, we współpracy ze środowiskiem naukowym i innymi partnerami, tworzą Regionalne Strategie Innowacji (RSI) oraz stałe 
struktury współdziałania $\mathrm{z}$ interesariuszami tego systemu, w skład których wchodzą zwłaszcza przedstawiciele nauki i edukacji.

Legislatorzy i kontrolerzy. Jest to rynek złożony zarówno z państwowych służb kontrolnych, wojewody, jak i sejmiku województwa, który sprawuje pieczę nad działaniami organu wykonawczego i podległymi mu strukturami administracyjnymi. Do tego rynku zaliczono też podmioty reprezentujące centralną administrację państwową. Będą to zatem sektorowe ministerstwa oraz agencje rządowe. Analiza materiału badawczego potwierdziła, że odpowiedzi respondentów administracji centralnej z Warszawy (np. ministerstwa) i z regionu (np. urząd wojewódzki) są podobne i to zadecydowało o zaliczeniu tych podmiotów do tego samego rynku. W celu oddziaływania na te grupy region może podejmować próby lobbowania wobec konkretnych decydentów, ale także budować relacje $\mathrm{z}$ władzami państwowymi przy realizacji miękkich projektów współpracy.

NGO. Jest to rynek organizacji pozarządowych. Działają na nim interesariusze realizujący zadania głównie w obszarze usług publicznych. Region powierza organizacjom pozarządowym część zadań publicznych. $\mathrm{W}$ polskich warunkach organizacje te są obecnie niedoceniane w obszarze gospodarki. Mają one świadomość swojej ograniczonej roli w kształtowaniu rozwoju gospodarczego. Respondenci najczęściej wskazywali na takie zachęty do współpracy z NGO, jak: potencjalnie większe możliwości realizacji postawionych przed samorząem zadań. Od kilku lat współpraca samorządu województwa z NGO ma charakter zinstytucjonalizowany. Przy samorządach terytorialnych powoływane są obowiązkowe struktury pod nazwą Wojewódzka Rada Działalności Pożytku Publicznego. Pozwalają one na prowadzenie dialogu $\mathrm{z}$ reprezentatywną grupą $\mathrm{NGO} \mathrm{z}$ całego regionu. Władze samorządowe regionu są zobligowane do corocznego przygotowywania programu współpracy z NGO w konsultacji z zainteresowanymi.

Pracownicy. Rozumiani są tu ogólnie jako dysponenci zasobów pracy. W tym kontekście mogą być reprezentowani przez samorządy zawodowe. Interesariusze ci byli najczęściej wymieniani jako partnerzy do współpracy przez menedżerów z urzędów marszałkowskich reprezentujących departamenty sektorowe. W tym kontekście mieszkańcy opisywani są przez pryzmat ich wykształcenia oraz kompetencji i doświadczeń zawodowych. W kontekście wzrostu znaczenia czynników jakościowych w procesach inwestycyjnych przedsiębiorstw oraz wzmożonego rozwoju sektora usług to właśnie zasoby ludzkie stają się rynkiem o rosnącym znaczeniu. $\mathrm{W}$ interesie regionu leży więc stymulowanie poprawy jego jakości.

Biznes. Rynek ten jest w Polsce słabo zinstytucjonalizowany. Organizacje samorządu gospodarczego nie posiadają prawnej reprezentacji. 
Niewielka skłonność do zrzeszania się przedsiębiorców przekłada się na niską reprezentatywność takich organizacji w miastach i regionach. W przypadku dużych, strategicznych dla regionu przedsiębiorstw współdziałanie może być podejmowane w sposób indywidualny. Jako czynniki stymulujące współpracę regionu $\mathrm{z}$ biznesem respondenci wymieniali: większe możliwości realizacji postawionych przed samorządem zadań oraz chęć skorzystania $z$ doświadczenia, wiedzy $i$ kompetencji przedsiębiorstw.

Należy zwrócić uwagę, że autor nie zdecydował się zaproponować odrębnych rynków dla takich podmiotów, jak: organizacje międzynarodowe, regiony innych państw czy samorządy innych województw w Polsce, mimo że takie podmioty były wymieniane $\mathrm{w}$ zrealizowanym badaniu empirycznym. Relacje z tymi podmiotami mają głównie charakter operacyjny i mają związek ze środowiskiem ponadregionalnym lub międzynarodowym. Zdaniem autora zasługują one na sformułowanie odrębnego modelu - modelu rynków umiędzynarodowienia regionu, co pozwoliłoby na uporządkowanie tych relacji, których znaczenie w najbliższych latach będzie rosło i podniesienia ich na wyższy poziom. Może to stanowić cel lub element innego badania. 


\section{Rozdział 6}

\section{Współdziatanie regionu i miasta w marketingowych procesach pozyskiwania mobilnych czynników wzrostu - wyniki badań empirycznych}

Prezentowane w tym rozdziale rezultaty badań dotyczą współdziałania pomiędzy regionem a wybraną lokalną jednostką samorządu terytorialnego, w kontekście rywalizacji regionów o mobilne zasoby wzrostu, będące $\mathrm{w}$ dyspozycji inwestorów, turystów i potencjalnych studentów. Autor podejmuje wyzwanie wyjaśnienia procesów współdziałania pomiędzy tymi organizacjami terytorialnymi na bazie teorii zależności od zasobów w wymiarze organizacyjnym. Teoria ta powstała dla opisania relacji pomiędzy organizacjami, z uwzględnieniem posiadania lub deficytu zasobów, potrzebnych do realizacji rynkowych celów tychże organizacji [Hatch 2002]. Jest to równocześnie próba wyjaśnienia rozwoju koncepcji marketingu terytorialnego $\mathrm{w}$ oparciu o teorię objaśniającą procesy współdziałania pomiędzy organizacjami.

Badaniami objęto osiem par podmiotów: region-stolica regionu, wyselekcjonowanych na podstawie oceny udziału posiadanych przez miasto zasobów, świadczących o jego atrakcyjności inwestycyjnej, turystycznej oraz akademickiej w zasobach regionu ogółem. Ocena ta miała na celu wybór skrajnych przypadków do badań. Wyodrębniono dwa przypadki: A, gdzie stolica posiada wysoki udział takich zasobów wobec tych zlokalizowanych na terytorium całego regionu oraz dwa przypadki B, gdzie stolica posiada takich zasobów najmniej. W każdym z tych przypadków badaniami objęto jednostki organizacyjne zajmujące się marketingiem, które $\mathrm{w}$ badaniach eksploracyjnych opisanych $\mathrm{w}$ rozdziale piątym nazywano jako „rynkowe”. W dokonywaniu oceny poziomu współdziałania $\mathrm{w}$ marketingowych procesach przyciągania mobilnych czynników 
wzrostu do regionu wykorzystano miernik Hellwiga. Zestawiono zasoby stolicy regionu $\mathrm{w}$ zasobach regionu ogółem, $\mathrm{z}$ miarą współdziałania region-miasto. Pozwoliło to na wyciągnięcie interesujących wniosków teoretycznych.

\subsection{Rola miast i regionów w dysponowaniu zasobami}

W niniejszym rozdziale, jak już zaznaczono, skoncentrowano się na jednej, wybranej relacji region-miasto. Prezentowane w rozdziale piątym rezultaty badań dowiodły, że to lokalne JST stanowią dla regionu, obok uczelni wyższych, najważniejszą grupę potencjalnych partnerów w procesach rozwojowych. W procesach tych kluczową rolę odgrywają relacje OT regionu ze stolicami województw, które będą analizowane w kontekście realizowanych przez region marketingowych procesów przyciągania inwestorów, turystów i studentów.

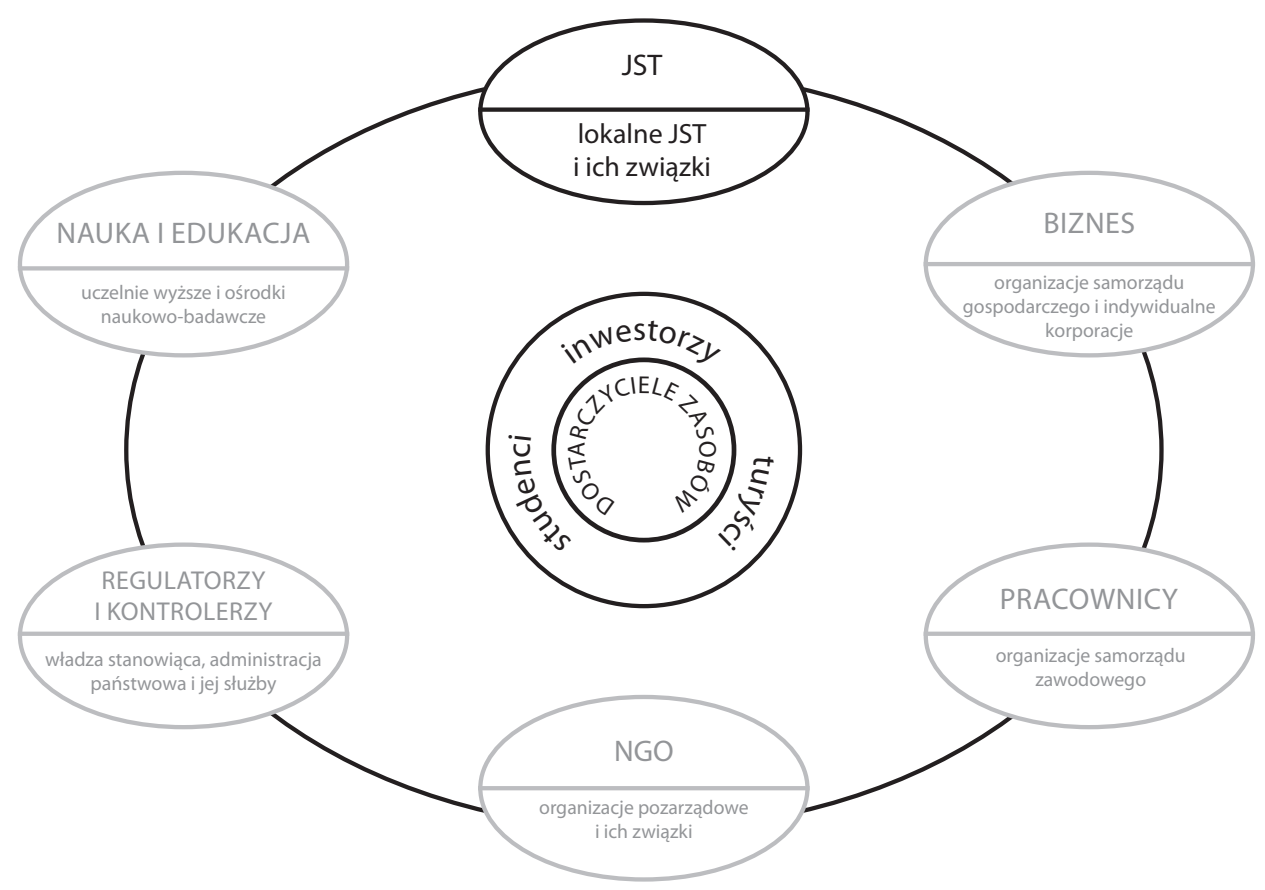

Rys. 6.1. Model marketingu terytorialnego na szczeblu regionu w ujęciu relacyjnym

Źródło: opracowanie własne. 
Na rys. 6.1 umieszczono model sześciu rynków dla organizacji terytorialnej, uzupełniony, $\mathrm{w}$ stosunku do prezentowanego $\mathrm{w}$ poprzednim rozdziale, o rynek użytkowników zewnętrznych regionu. W skład tego ostatniego wchodzą inwestorzy, turyści i studenci będący mobilnymi, pożądanymi przez terytoria użytkownikami, dostarczającymi zasoby ważne dla mieszkańców, rozumianych jako udziałowców terytorium. Klientem, $\mathrm{w}$ przyjętym rozumieniu marketingu terytorialnego, jest zatem zewnętrzny użytkownik terytorium, którego celowo umieszczono w centrum rys. 6.1. Region prowadzi zatem procesy marketingowe, zorientowane na pozyskiwanie tych grup docelowych, współpracując przy tym z poszczególnymi grupami interesariuszy. Są one jednak na tyle różne, że każdą relację region-interesariusz instytucjonalny (np. lokalne JST, interesariusze z rynku nauki i edukacji) należy opisywać na bazie innych teorii, adekwatnych do specyfiki tych relacji, z uwzględnieniem formalizacji relacji, skali zależności itp.

Należy podkreślić, że faktycznym gospodarzem dla inwestorów są miasta (zwłaszcza te realizujące zadania gminy i powiatu równocześnie), bowiem tam załatwia się większość formalności związanych z procesem inwestycyjnym. Miasta często są również ważnymi ośrodkami recepcji turystycznej, zwłaszcza w tzw. turystyce biznesowej. Posiadają ponadprzeciętnie rozbudowaną bazę noclegową, gastronomiczną, sportową, kulturalną, która przyciąga wszystkie grupy turystów. Stanowią również centra akademickie, przyciągając rokrocznie dziesiątki tysięcy nowych studentów spoza regionu.

$\mathrm{W}$ procesach rozwojowych ważne jest to, kto jest dysponentem zasobów istotnych z punktu widzenia potencjalnych użytkowników terytorium, a także kto ma na nie pośredni lub bezpośredni wpływ. Przykładowo dysponentem hoteli i restauracji są prywatni przedsiębiorcy. Natomiast pośredni wpływ na ich lokalizację i funkcjonowanie posiadają zwłaszcza służby miejskie, a nie wojewódzkie. W przypadku instytucji kultury (zasoby pożądane przez turystów i inwestorów) to miasto jest organem stanowiącym dla większości teatrów czy muzeów, chociaż należy pamiętać, że w gestii samorządu regionu znajdują się takie podmioty, jak filharmonia czy opera, których skala oddziaływania jest ponadlokalna. W przypadku rynku akademickiego to uczelnie publiczne (podlegające Ministerstwu Nauki i Szkolnictwa Wyższego) są aktorami tego rynku. Starają się one rozbudowywać swoje kampusy, by zapewnić jak najlepszy standard swoim studentom. Miasto może jednak mniej lub bardziej sprzyjać rozwojowi funkcji akademickich na swoim terytorium poprzez definiowanie nowych lokalizacji, rozwijanie dogodnego lokalnego transportu, infrastruktury usługowo-gastronomicznej dla studentów, infrastruktury sportowej itp. W związku z powyższym przyjęto założenie, że 
to miasta, stolice regionów (łączące funkcje gminy i powiatu), posiadają najszersze kompetencje i wpływ na zasoby, ważne w procesie przyciągania inwestorów, turystów i studentów do terytorium.

Regiony natomiast posiadają głównie pośrednie instrumenty oddziaływania na dysponentów zasobów w ramach prowadzonej polityki rozwoju, która jest szeroko wspierana przez fundusze unijne. Samorządy regionów, doskonaląc system instytucjonalny, wykorzystywany w procesie prowadzenia polityki rozwoju, starają się zwiększać swoją kontrolę nad podmiotami, którym powierzono realizację określonych funkcji. Jako przykład można tu przywołać Łódzką Agencję Rozwoju Regionalnego, w której udziały samorządu województwa w ciągu ostatnich kilku lat szybko rosły, aż do uzyskania całkowitej nad nią kontroli. Podobnie stało się w województwie małopolskim, które w taki sam sposób wykreowało instytucję (Małopolską Agencję Rozwoju Regionalnego) zarządzającą polityką rozwoju regionu w zakresie wspierania sektora MSP. Częściej jednak nie ma możliwości ograniczania zależności poprzez działania formalne, a jedyną metodą jej ograniczania są tzw. miękkie formy oddziaływania, jak współdziałanie.

Należy przypomnieć, że kompetencje samorządowych regionów obejmują działania na rzecz generowania rozwoju, podnoszenia pozycji konkurencyjnej województwa, co ma prowadzić do szerszego napływu do regionu zewnętrznych zasobów wzrostu, których nośnikami są inwestorzy, turyści czy studenci. Każdy z tych docelowych rynków użytkowników jest specyficzny i wobec każdego z nich organizacja terytorialna na szczeblu regionu oddziałuje przy pomocy określonych jednostek organizacyjnych i instrumentów. Przykładowo, w urzędach marszałkowskich funkcjonują departamenty dedykowane promocji gospodarczej, turystycznej, wspieraniu rozwoju gospodarczego, współpracy z regionami partnerskimi czy rozwojowi przedsiębiorczości.

\subsection{Klasyfikacja regionów ze względu na udział stolicy w zasobach regionu ogółem}

Należy przypomnieć, że w procesie klasyfikacji par region-miasto będziemy się koncentrować na zasobach, które są pożądane z perspektywy potencjalnych zewnętrznych rynków docelowych w postaci inwestorów, turystów i studentów. W dalszych analizach wykorzystano ocenę poziomu zróżnicowania udziału zasobów będących w dyspozycji miasta (stolicy regionu) lub pod jego wpływem, w zasobach ogółem (zlokalizowanych na terenie całego regionu), opisanych za pomocą zestawu wybranych cech 
statystycznych. Dążono do otrzymania jednorodnych typów regionów ze względu na posiadane/kontrolowane zasoby [Kopczewska, Kopczewski, Wójcik 2009; Młodak 2006]. Twórcą wielowymiarowej analizy porównawczej był Z. Hellwig [1968]. Skonstruowane przez niego mierniki znajdują zastosowanie w wielu pracach dotyczących klasyfikacji.

W badaniach posłużono się taksonomiczną metodą wzorca rozwoju Z. Hellwiga [Suchecki 2010], która konstruuje syntetyczny miernik, zbudowany $\mathrm{w}$ oparciu o mierniki cząstkowe, obrazujące poszczególne aspekty danego zasobu. W metodzie tej istotne jest ujednolicenie poziomu zmienności wykorzystywanych cech, $\mathrm{w}$ celu zapewnienia ich porównywalności. W badaniach wykorzystano udziały wartości $j$-tego zasobu stolicy $i$-tego regionu do wartości tego zasobu w $i$-tym regionie obliczone w oparciu o wzór:

$$
p_{i j}=\frac{x s_{i j}}{x_{i j}}, \quad i=1,2, \ldots, n ; j=1,2, \ldots, m
$$

gdzie:

$p_{i j}$ - udziały wartości j-tego zasobu w stolicy $i$-tego regionu, do wartości tego zasobu w $i$-tym regionie;

$x_{i j} \quad$ - wartości empiryczne $j$-tego zasobu w $i$-tym regionie;

$x s_{i j}$ - wartości empiryczne $j$-tego zasobu w $i$-tej stolicy.

W wyniku zastosowania tej formuły otrzymujemy zmienne o wartościach należących do przedziału $[0 ; 1]$. Na bazie tych udziałów, obliczono syntetyczne miary potencjału, przy pomocy metody wzorca rozwoju Z. Hellwiga i sporządzono rankingi regionów dla każdego badanego potencjału, czyli dla rynku inwestycyjnego, turystycznego i akademickiego [Górniak, Wachnicki 2010; Salamaga 2010]. Syntetyczną miarę potencjału obliczono, jako średnią arytmetyczną ważoną wyznaczonych udziałów, według wzoru:

$$
z_{i}=\sum_{j=1}^{m} w_{j} p_{i j}, \quad i=1,2, \ldots, n ; j=1,2, \ldots, m
$$

gdzie:

$z_{i} \quad$ - syntetyczna miara potencjału $w i$-tym regionie,

$p_{i j}$ - udziały wartości $j$-tego zasobu w stolicy $i$-tego regionu do wartości tego zasobu w $i$-tym regionie,

$w_{j}$ - subiektywnie ustalona waga ważności $j$-tego zasobu, przy czym

$$
\sum_{j=1}^{m} w_{j}=1
$$


Syntetyczna miara rozwoju stanowiła następnie podstawę klasyfikacji regionów, ze względu na jednorodne grupy, z punktu widzenia osiągniętego potencjału. Całkowity przedział zmienności syntetycznej miary potencjału regionów podzielono na trzy przedziały klasowe (tab. 6.1), do których przypisano poszczególne jednostki badania według wzoru [Łogwiniuk 2011, s. 7-23]:

Tabela 6.1. Przedział zmienności syntetycznej miary potencjału regionów z podziałem na trzy przedziały klasowe

\begin{tabular}{|l|l|}
\hline I- wysoki poziom & $z_{i} \in\left\langle\max _{i} z_{i} ; \max _{i} z_{i}-h\right)$ \\
\hline II- średni poziom & $z_{i} \in\left\langle\max _{i} z_{i}-h ; \max _{i} z_{i}-2 h\right)$ \\
\hline III - niski poziom & $z_{i} \in\left\langle\max _{i} z_{i}-2 h ; \min _{i} z_{i}\right\rangle$ \\
\hline
\end{tabular}

Źródło: opracowanie własne.

Rozpiętość przedziałów klasowych ustalono na podstawie stałej $h$, wyznaczonej według:

$$
h=\frac{\max _{i} z_{i}-\min _{i} z_{i}}{3} \quad \text { dla } i=1, \ldots, n
$$

Analizy przeprowadzono w czterech krokach. Najpierw dla poszczególnych grup zasobów (zasoby ważne dla inwestorów, zasoby ważne dla turystów, zasoby ważne dla potencjalnych studentów), a następnie łącznie dla wszystkich. Kierując się specyfiką poszczególnych rynków docelowych w zakresie roli czynników związanych z wizerunkiem, popularnością, modą, przy wyborze destynacji, zróżnicowano udział takich czynników w czynnikach ogółem. Podział ten uwzględnia specyfikę rynku inwestycyjnego, gdzie rola tzw. miękkich kryteriów jest relatywnie mała oraz rynku turystycznego, gdzie rola miękkich kryteriów jest relatywnie duża. Ostatecznie przyjęto następujące udziały: dla rynku inwestycyjnego - 20\%, turystycznego - 40\% i akademickiego - 30\%. Przydzielone wagi są adekwatne do wrażliwości uczestników tych rynków na dotychczasowe zjawiska mające wpływ na wizerunek, a mierzone np. liczbą dotychczasowych inwestycji zagranicznych, turystów czy studentów w danym regionie. Zaproponowane udziały przedstawiono na rys. 6.2. 


\begin{tabular}{|c|c|c|}
\hline Zasoby inwestycyjne & $80 \%$ & $20 \%$ \\
\hline Zasoby turystyczne & $60 \%$ & $40 \%$ \\
\hline Zasoby akademickie & $70 \%$ & $30 \%$ \\
\hline
\end{tabular}

Rys. 6.2. Relacja zasobów niematerialnych (pole szare) do zasobów materialnych terytorium (pole czarne) jako kryterium wyboru terytorium, z perspektywy potencjalnych użytkowników zewnętrznych na poszczególnych rynkach

Źródło: jak do rys. 6.1 .

Reasumując można stwierdzić, że rynek inwestycyjny przejawia w stosunku do pozostałych wyższy poziom racjonalności podejmowanych decyzji. Na drugim biegunie występuje rynek turystyczny, charakteryzujący się dużą dozą decyzji impulsowych i znacznie krótszym niż w przypadku rynku inwestycyjnego procesem podejmowania decyzji.

\subsection{Oceny potencjału stolicy $w$ regionie z perspektywy atrakcyjności inwestycyjnej, turystycznej i akademickiej}

\subsubsection{Rola stolicy w regionie na rynku inwestycyjnym}

Przy ocenie potencjału inwestycyjnego badanych terytoriów wykorzystano uproszczoną klasyfikację zasobów, wykorzystywaną przez Instytut Badań nad Gospodarką Rynkową [2015]. Standardowo przyjęto wagę 20\% dla każdej grupy czynników z dwoma wyjątkami. Zdecydowano się podwyższyć wagę w przypadku rynku pracy w związku z faktem, że to właśnie jakościowe czynniki zaczęły w ostatnich latach nabierać znaczenia dla inwestorów. Natomiast zdecydowano się obniżyć wagę dla infrastruktury społecznej, co związane było z deficytem danych, dostępnych równocześnie na poziomie regionu, jak i miasta, co mogłoby skutkować nadmiernie wysokim poziomem tylko jednej cechy, dla której pozyskano dane (liczba obiektów kultury).

W rezultacie kategorie zasobów oraz ich wagi z punktu widzenia inwestorów przedstawiają się w następujący sposób:

- reputacja terytorium $(20 \%)$;

- zasoby pracy (30\%);

- infrastruktura gospodarcza (20\%); 
- infrastruktura społeczna (10\%);

- rynek zbytu i kooperanci (20\%).

Wybrane cechy statystyczne charakteryzujące powyższe kategorie pozyskano w Banku Danych Lokalnych GUS dla lat 2009-2013. W związku z tym, że baza ta niekiedy nie posiada danych na poziomie miast (tylko regionów) wykorzystane cechy zostały zdeterminowane dostępnością danych, równocześnie na szczeblu regionu i miasta. Ponieważ funkcje targowe zlokalizowane są niemal w całości w stolicy województw, co nie różnicowałoby badanych par, zdecydowano się nie włączać tej cechy do obliczeń. Natomiast w przypadku danych dotyczących infrastruktury naukowo-badawczej, w sytuacji braku danych agregowanych na poziomie miast, zdecydowano się skorzystać z raportu opracowanego przez Stowarzyszenie Organizatorów Ośrodków Innowacji i Przedsiębiorczości w Polsce, które posiada wysoką renomę w zakresie sporządzania analiz dotyczących tego rynku [Bąkowski, Mażewska 2015].

Ostatecznie w analizie wzięto pod uwagę następujące zasoby wraz z ich wagami (tab. 6.2). Część tych zasobów została opisana bardziej szczegółowo w stosunku do poprzedniego zestawienia.

Tabela 6.2. Cechy statystyczne opisujące zasoby inwestycyjne terytoriów ważne dla inwestorów

\begin{tabular}{|l|c|}
\multicolumn{1}{|c|}{ Cecha statystyczna } & Udział (\%) \\
\hline Liczba firm z kapitałem zagranicznym & 20 \\
\hline Liczba pracujących & 7,5 \\
\hline Liczba poszukujących pracy & 7,5 \\
\hline Liczba absolwentów uczelni & 7,5 \\
\hline $\begin{array}{l}\text { Liczba absolwentów szkół ponadgimnazjalnych o profilu zawodowym, } \\
\text { technicznym (gotowych do podjęcia pracy) }\end{array}$ & 7,5 \\
\hline Liczba jednostek sektora badawczo-rozwojowego & 20 \\
\hline Liczba obiektów kultury & 10 \\
\hline Liczba mieszkańców & 10 \\
\hline Liczba przedsiębiorstw & 10 \\
\hline
\end{tabular}

Źródło: opracowanie własne z zastosowaniem cech wykorzystywanych przez IBnGR [2015].

Dla zestawu zasobów, mających podstawowe znaczenie na rynku inwestycyjnym (stanowią o atrakcyjności inwestycyjnej terytorium), na podstawie informacji pozyskanych z Banku Danych Lokalnych, wyznaczono (tab. 6.3; rys. 6.3) syntetyczną miarę dla udziału zasobów stolicy w zasobach regionu ogółem: 
Tabela 6.3. Syntetyczna miara dla udziału zasobów stolicy w zasobach regionu ogółem na rynku inwestycyjnym

\begin{tabular}{|l|c|c|}
\hline \multicolumn{1}{|c|}{ Województwo } & $\begin{array}{c}\text { Ważony syntetyczny miernik udziału zasobów } \\
\text { stolicy w regionie } \\
\text { (RYNEK INWESTYCYJNY) }\end{array}$ & $\begin{array}{c}\text { Miejsce } \\
\text { w rankingu }\end{array}$ \\
\hline Małopolskie & 0,443888 & 1 \\
\hline Łódzkie & 0,442409 & 2 \\
\hline Lubelskie & 0,382869 & 3 \\
\hline Zachodniopomorskie & 0,373177 & 4 \\
\hline Świętokrzyskie & 0,341602 & 5 \\
\hline Wielkopolskie & 0,330742 & 6 \\
\hline Warmińsko-mazurskie & 0,240337 & 8 \\
\hline Podkarpackie & 0,236944 & 7 \\
\hline
\end{tabular}

Źródło: jak do tab. 6.1 .

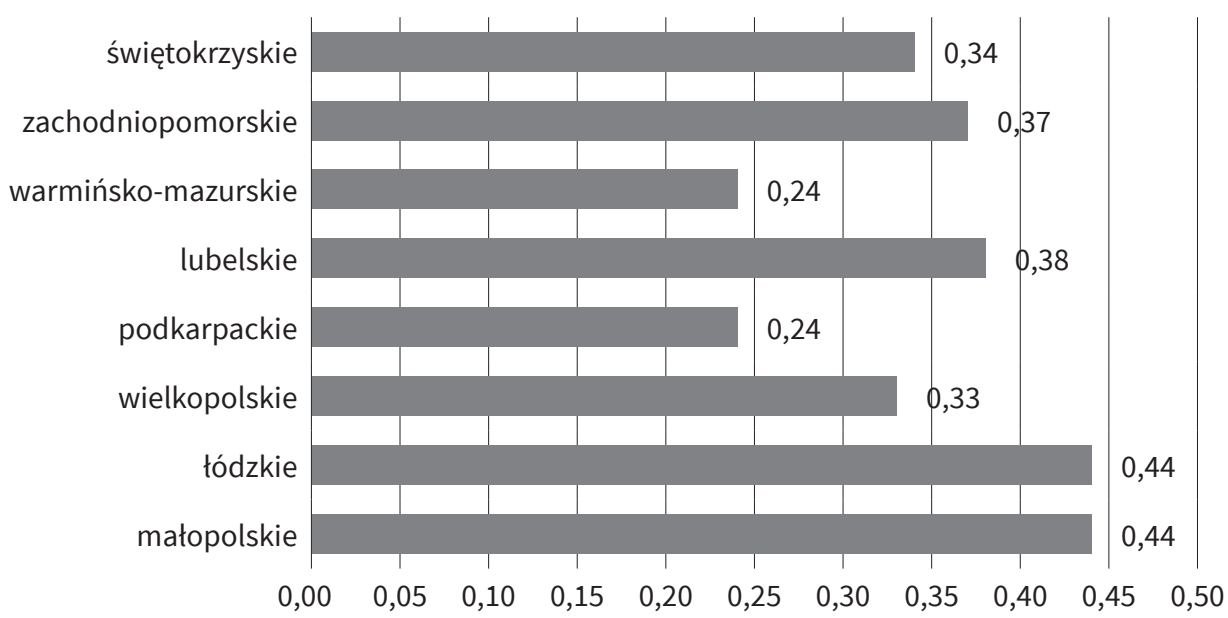

Rys. 6.3. Ważony syntetyczny miernik udziału zasobów stolicy w zasobach regionu ogółem na rynku inwestycyjnym

Źródło: jak do rys. 6.1.

W wyniku przeprowadzonych obliczeń z wykorzystaniem zaproponowanej metody klasyfikacji otrzymano podział województw według trzech poziomów miernika, który został zaprezentowany w tab. 6.4. 
Tabela 6.4. Poziomy miernika potencjału stolicy w regionie na rynku inwestycyjnym

\begin{tabular}{|c|c|l|}
\hline Poziom miernika & \multicolumn{1}{|c|}{ Zakres } & \multicolumn{1}{c|}{ Województwa } \\
\hline I - wysoki poziom & $<0,443 ; 0,375)$ & małopolskie, tódzkie, lubelskie \\
\hline II - średni poziom & $<0,375 ; 0,306)$ & $\begin{array}{l}\text { świętokrzyskie, zachodniopomorskie, } \\
\text { wielkopolskie }\end{array}$ \\
\hline III - niski poziom & $<0,306 ; 0,236>$ & warmińsko-mazurskie, podkarpackie \\
\hline
\end{tabular}

Źródło: opracowanie własne z wykorzystaniem metody wzorca rozwoju Hellwiga.

W grupie województw, w których pozycja stolicy pod względem posiadanych zasobów ważnych dla inwestorów jest najwyższa, znalazły się takie, jak: małopolskie, łódzkie i lubelskie. Szczególnie wysokim miernikiem wykazały się dwa pierwsze. $\mathrm{W}$ tab. 6.4 pokazano wysokie pozycje Krakowa, Łodzi i Lublina w swoich regionach. Należy zwrócić uwagę, że przyjęto relatywnie wysoki udział w mierniku zasobów związanych z rynkiem akademickim, co musiało mieć bezpośredni wpływ na te wyniki. Wszystkie wymienione miasta są bowiem w czołówce spośród badanych ośmiu, jeżeli chodzi o pozycję na rynku akademickim. Natomiast województwo wielkopolskie, mimo że w rankingach atrakcyjności inwestycyjnej wypada zwykle dobrze, w zestawieniu tym zostało zaklasyfikowane do średniego poziomu miernika. Warto wyjaśnić, że Wielkopolska jest jednym z większych regionów Polski, zaś obok jej stolicy prężnie rozwijają się alternatywne lokalizacje dogodne dla inwestorów na terenie regionu.

$\mathrm{Na}$ przeciwnym biegunie, gdzie udział stolicy w zasobach jest relatywnie słabszy, znalazły się województwa: warmińsko-mazurskie oraz podkarpackie. Faktycznie, trudno nazwać Olsztyn centrum inwestycyjnym. Sytuacja Rzeszowa jest inna - wiele inwestycji produkcyjnych w województwie podkarpackim jest zlokalizowanych poza stolicą regionu.

\subsubsection{Rola stolicy $w$ regionie na rynku turystycznym}

W dalszej analizie wzięto pod uwagę cechy z określonymi wagami zaprezentowane $\mathrm{w}$ tab. 6.5. Autor zdaje sobie sprawę $\mathrm{z}$ uproszczenia zaproponowanego zestawienia zasobów i nieuwzględnienia takich np. zasobów, jak atrakcje turystyczne. Bazując jednak na danych statystycznych w BDL, musiał ograniczyć się do dostępnych tam informacji.

Przyjęto, że liczba noclegów udzielonych turystom krajowym i zagranicznym jest miarą popularności określonych terytoriów, które mają znaczenie dla potencjalnych turystów. Większość turystów wybiera przecież te destynacje, które są popularne na rynku. Natomiast wśród zasobów o charakterze infrastrukturalnym zidentyfikowano przede wszystkim 
obiekty noclegowe, konferencyjne oraz nową kategorię w BDL: liczbę uczestników imprez masowych. Zatem dla zestawu zasobów mających podstawowe znaczenie na rynku turystycznym (stanowią o atrakcyjności turystycznej terytorium) wyznaczono (tab. 6.6; rys. 6.4) następującą syntetyczną miarę dla udziału zasobów stolicy w zasobach regionu ogólem:

Tabela 6.5. Cechy statystyczne opisujące zasoby turystyczne terytoriów

\begin{tabular}{|l|c|}
\hline \multicolumn{1}{|c|}{ Cecha statystyczna } & Waga (\%) \\
\hline Liczba noclegów udzielona turystom krajowym & 20 \\
\hline Liczba noclegów udzielona turystom zagranicznym & 20 \\
\hline Liczba obiektów hotelowych & 15 \\
\hline Liczba obiektów z salą konferencyjną & 15 \\
\hline Liczba miejsc w salach konferencyjnych & 15 \\
\hline Liczba imprez masowych & 15 \\
\hline
\end{tabular}

Źródło: jak do tab. 6.1.

Tabela 6.6. Syntetyczna miara dla udziału zasobów stolicy w zasobach regionu ogółem na rynku turystycznym

\begin{tabular}{|l|c|c|}
\hline \multicolumn{1}{|c|}{ Województwo } & $\begin{array}{c}\text { Ważony syntetyczny miernik udziału zasobów } \\
\text { stolicy w zasobach regionu } \\
\text { (RYNEK TURYSTYCZNY) }\end{array}$ & $\begin{array}{c}\text { Miejsce } \\
\text { w rankingu }\end{array}$ \\
\hline Małopolskie & 0,4116 & 1 \\
\hline Łódzkie & 0,3394 & 2 \\
\hline Wielkopolskie & 0,3060 & 3 \\
\hline Lubelskie & 0,2767 & 4 \\
\hline Świętokrzyskie & 0,2161 & 5 \\
\hline Podkarpackie & 0,1783 & 6 \\
\hline Zachodniopomorskie & 0,1485 & 8 \\
\hline Warmińsko-mazurskie & 0,1418 & 7 \\
\hline
\end{tabular}

Źródło: jak do tab. 6.1.

Spośród ośmiu badanych par miasto-region należy zwrócić uwagę na wyróżniającą się pozycję stolicy Małopolski - Krakowa, który jest w skali kraju numerem jeden, jeżeli chodzi o zasoby destynacji turystycznej. Jego potencjał i rozpoznawalność związane są z posiadanymi zasobami historycznymi oraz rozwiniętymi funkcjami kulturalnymi, wzmocnionymi 
faktem posiadania już kilkanaście lat temu tytułu Europejskiej Stolicy Kultury. Dwie kolejne, a zarazem wysokie pozycje w tym rankingu wobec swoich regionów zajmują Łódź oraz Poznań. Należy podkreślić, że $\mathrm{w}$ tych przypadkach potencjał obu ośrodków wynika $\mathrm{z}$ biznesowego charakteru turystyki. Dotyczy to zwłaszcza Poznania, gdzie nadal znaczny ruch turystyczny generują Międzynarodowe Targi Poznańskie. W Łodzi natomiast na rozwój turystyki w ostatnich latach wpłynął w istotny sposób wzrost zasobów noclegowych po oddaniu do użytku kilku nowych hoteli. Potencjał rozwijającego się Uniejowa to domena dopiero ostatnich lat (2014-2015), czego nie objęły jeszcze wykorzystywane w tym zestawieniu statystyki.

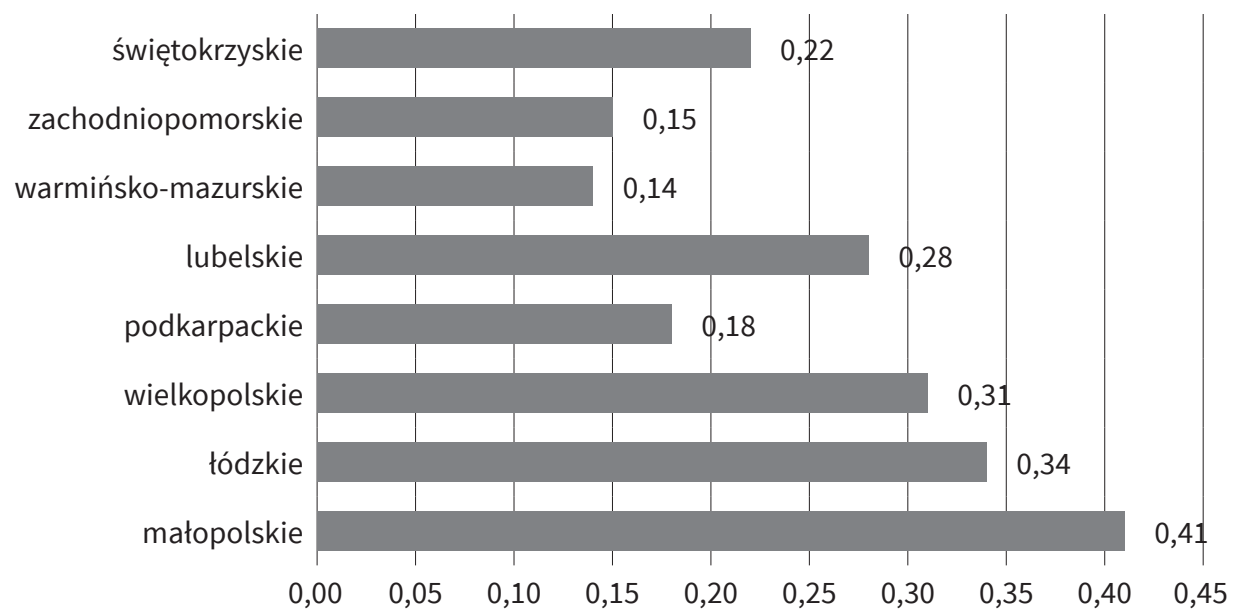

Rys. 6.4. Ważony syntetyczny miernik udziału zasobów stolicy w zasobach regionu ogółem na rynku turystycznym

Źródło: jak do rys. 6.1 .

W regionach łódzkim i wielkopolskim, poza stolicą, nie ma większych ośrodków dysponujących zasobami pożądanymi przez tę grupę, co ma wpływ na relatywnie mniejszą recepcję turystyczną na tych obszarach. Przykładowo w takich regionach, jak: warmińsko-mazurski, zachodniopomorski czy podkarpacki sytuacja jest odwrotna. Tam ośrodki poza stolicą generują wysoki ruch turystyczny (ośrodki nadmorskie typu Międzyzdroje, obszary jezior mazurskich, Bieszczady), a same stolice nie posiadają wystarczających zasobów, aby skutecznie generować ruch w tzw. turystyce wypoczynkowej, zaś turystyka biznesowa jest tam proporcjonalna do potencjału gospodarczego tych miast. 
W wyniku przeprowadzonych obliczeń z wykorzystaniem zaproponowanej metody klasyfikacji otrzymano podział województw według trzech poziomów miernika, co zaprezentowano w tab. 6.7.

Tabela 6.7. Poziomy miernika potencjału stolicy w regionie na rynku turystycznym

\begin{tabular}{|l|c|l|}
\hline I - wysoki poziom & $<0,411 ; 0,321)$ & małopolskie, tódzkie \\
\hline II - średni poziom & $<0,321 ; 0,232)$ & wielkopolskie, lubelskie \\
\hline III - niski poziom & $<0,232 ; 0,141>$ & $\begin{array}{l}\text { świętokrzyskie, zachodniopomorskie, warmińsko- } \\
\text {-mazurskie, podkarpackie }\end{array}$ \\
\hline
\end{tabular}

Źródło: jak do tab. 6.4 .

W grupie wysokiego poziomu miernika znalazły się dwa regiony, które posiadają skrajnie różne zasoby turystyczne. Wynik taki można wyjaśnić w ten sposób, że po pierwsze regiony te reprezentują skrajne wartości miernika na tym poziomie, a po drugie zestawienie dotyczy relacji region-stolica, która właśnie w przypadku małopolskiego i łódzkiego jest podobna. Zwraca uwage relatywnie wysoka pozycja Lublina $\mathrm{w}$ regionie. Jest to związane $\mathrm{z}$ faktem, że o ile w przypadku Podkarpacia pozycję Rzeszowa zmniejszają turystyczne ośrodki górskie, to w przypadku województwa lubelskiego, poza Kazimierzem Dolnym czy Nałęczowem, potencjał turystyczny regionu jest ograniczony.

\subsubsection{Rola stolicy w regionie na rynku akademickim}

Dla określenia potencjału stolicy w regionie na rynku akademickim kierowano się liczbą dotychczasowych studentów oraz ofertą uczelni wyższych. W związku z brakiem danych na temat liczby dostępnych kierunków studiów czy innych informacji pozwalających ocenić potencjał poszczególnych ośrodków akademickich $\mathrm{w}$ poszczególnych miastach i regionach, zdecydowano się na uproszczone podejście w postaci liczby uczelni zlokalizowanych na danym terenie. Przyjęto zatem następujące wagi: liczba studentów (30\%), liczba szkół wyższych (70\%).

Dla zestawu zasobów mających podstawowe znaczenie na rynku akademickim (stanowią o atrakcyjności akademickiej terytorium) wyznaczono syntetyczną miarę dla udziału zasobów stolicy w zasobach regionu, co zaprezentowano $\mathrm{w}$ tab. $6.8 \mathrm{i}$ na rys. 6.5.

Dokonując interpretacji tego zestawienia, należy mieć na względzie, że starano się pokazać potencjał stolicy na tle całego regionu. W przypadku rynku akademickiego uzwględniono miary ilościowe, a nie jakościowe, co 
spowodowało, że to nie Małopolska z Krakowem znalazła się na pierwszej pozycji. Okazuje się bowiem, że to Łódź, Szczecin i Kielce posiadają w swoich regionach niemal monopol na funkcje akademickie, podczas gdy pozostałe stolice województw dzielą się tym potencjałem $\mathrm{z}$ innymi miastami w swoich regionach. Przykładowo Lublin i Rzeszów dzielą się funkcjami akademickimi z takimi ośrodkami, jak: Zamość, Puławy czy Przemyśl, Jasło, Krosno i Mielec. Natomiast w Małopolsce oprócz Krakowa funkcje te realizowane są w Nowym Sączu, Tarnowie czy Nowym Targu.

Tabela 6.8. Syntetyczna miara dla udziału zasobów stolicy w zasobach regionu ogółem na rynku akademickim

\begin{tabular}{|l|c|c|}
\hline \multicolumn{1}{|c|}{ Województwo } & $\begin{array}{c}\text { Ważony syntetyczny miernik udziału zasobów } \\
\text { stolicy w regionie } \\
\text { (RYNEK AKADEMICKI) }\end{array}$ & $\begin{array}{c}\text { Miejsce } \\
\text { w rankingu }\end{array}$ \\
\hline Łódzkie & 0,814413 & 1 \\
\hline Zachodniopomorskie & 0,752813 & 2 \\
\hline Świętokrzyskie & 0,740982 & 3 \\
\hline Małopolskie & 0,739167 & 4 \\
\hline Wielkopolskie & 0,719916 & 5 \\
\hline Warmińsko-mazurskie & 0,609142 & 6 \\
\hline Lubelskie & 0,593387 & 8 \\
\hline Podkarpackie & 0,448580 & 8 \\
\hline
\end{tabular}

Źródło: jak do tab. 6.1.

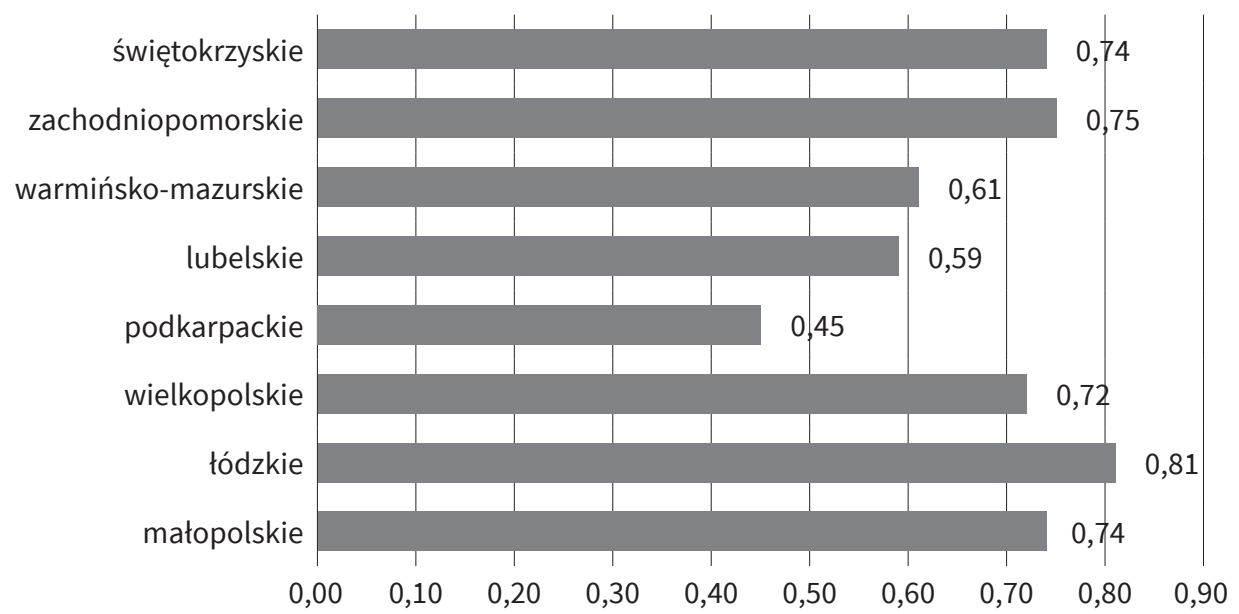

Rys. 6.5. Ważony syntetyczny miernik udziału zasobów stolicy w zasobach regionu ogółem na rynku akademickim

Źródło: jak do rys. 6.1. 
W wyniku przeprowadzonych obliczeń z wykorzystaniem zaproponowanej metody klasyfikacji otrzymano podział województw według trzech poziomów miernika, co zaprezentowano w tab. 6.9.

Tabela 6.9. Poziomy miernika potencjału stolicy w regionie na rynku akademickim

\begin{tabular}{|l|l|l|}
\hline I- wysoki poziom & $<0,814 ; 0,692)$ & $\begin{array}{l}\text { tódzkie, małopolskie, wielkopolskie, } \\
\text { świętokrzyskie, zachodniopomorskie }\end{array}$ \\
\hline II - średni poziom & $<0,692 ; 0,571)$ & warmińsko-mazurskie, lubelskie \\
\hline III - niski poziom & $<0,571 ; 0,448>$ & podkarpackie \\
\hline
\end{tabular}

Źródło: jak do tab. 6.4.

Należy jeszcze raz podkreślić, że w odróżnieniu do rynków: inwestycyjnego i turystycznego, w przypadku rynku akademickiego istnieje dominacja stolicy województwa, jeżeli chodzi o lokalizację jego potencjału $\mathrm{w}$ regionie. Zaobserwowane różnice są relatywnie niewielkie i w praktyce trudno mówić o wyraźnie skrajnych przypadkach.

\subsubsection{Zasoby stolicy $w$ regionie $w$ ujęciu syntetycznym}

Dotychczasowa analiza pokazała, że udział miast - stolic województw $\mathrm{w}$ zasobach regionu jest zróżnicowany na poszczególnych rynkach. W związku z tym w rankingu poszczególnych rodzajów zasobów zajmowały one różne miejsca. Spróbujmy obecnie określić w sposób syntetyczny pozycję zasobów stolicy łącznie na wszystkich tych rynkach. $\mathrm{W}$ dalszej analizie uwzględniono odpowiednio zasoby z określonymi wagami zestawione w tab. 6.10.

W badaniu przyjęto, że miasto (stolica regionu) posiada relatywnie mniejszy wpływ na zasoby stanowiące o atrakcyjności akademickiej. W tym przypadku to uczelnie wyższe, podlegające MNiSW w Warszawie, posiadają zdecydowanie największy wpływ na kształtowanie zasobów, mogących wpływać na wybór uczelni i kierunku studiów. Zdarza się jednak, że miasto wpływa bezpośrednio na tworzenie nowych kierunków studiów (np. w Łodzi utworzono na uczelniach kierunek logistyka, w kontekście planowanej budowy skrzyżowania autostrad, czy kierunek rewitalizacja, w kontekście rozpoczynania wielkiego miejskiego projektu dotyczącego rewitalizacji śródmieścia, o co zabiegały władze miasta). Jednak w porównaniu z kilkudziesięcioma kierunkami na każdej uczelni jest to wpływ relatywnie niewielki. 
Tabela 6.10. Cechy statystyczne wybrane dla określenia udziału stolicy w regionie w zakresie zasobów turystycznych, akademickich i inwestycyjnych

\begin{tabular}{|l|c|}
\hline \multicolumn{1}{|c|}{ Cecha statystyczna } & Waga (\%) \\
\hline Liczba noclegów udzielona turystom krajowym & $8 \%$ \\
\hline Liczba noclegów udzielona turystom zagranicznym & $8 \%$ \\
\hline Liczba obiektów hotelowych & $6 \%$ \\
\hline Liczba obiektów z salą konferencyjną & $6 \%$ \\
\hline Liczba miejsc w salach konferencyjnych & $6 \%$ \\
\hline Liczba imprez masowych & $6 \%$ \\
\hline Liczba studentów & $6 \%$ \\
\hline Liczba szkół wyższych & $14 \%$ \\
\hline Liczba firm z kapitałem zagranicznym & $8 \%$ \\
\hline Liczba pracujących & $3 \%$ \\
\hline Liczba poszukujących pracy & $3 \%$ \\
\hline Liczba absolwentów uczelni & $3 \%$ \\
\hline Liczba absolwentów szkół ponadgimnazjalnych & $3 \%$ \\
\hline Liczba jednostek sektora badawczo-rozwojowego & $8 \%$ \\
\hline Liczba obiektów kultury & $4 \%$ \\
\hline Liczba mieszkańców & $4 \%$ \\
\hline Liczba przedsiębiorstw & $4 \%$ \\
\hline
\end{tabular}

Źródło: jak do tab. 6.1.

Za obniżeniem wagi dla rynku akademickiego do $20 \%$, jako składowej ogólnej miary potencjału stolicy w regionie, przemawiała także specyfika rynku akademickiego, gdzie mamy do czynienia z dominacją stolicy w całym regionie. Chociaż w Europie Zachodniej niektóre najlepsze uczelnie są lokalizowane poza wielkimi miastami (Cambridge, Oxford), to trudno się spodziewać, że szybko stanie się tak również w Polsce. Jednocześnie wagi dla rynków inwestycyjnego i turystycznego, jako składowych miary potencjału stolicy w regionie, ważnego dla użytkowników zewnętrznych ustanowiono na poziomie po $40 \%$. Syntetyczne miary potencjału dla poszczególnych regionów zaprezentowano $\mathrm{w}$ tab. 6.11 i na rys. 6.6.

Pośród badanych par (region-miasto) najwyższym udziałem zasobów stolicy na tle regionu charakteryzuje się małopolskie-Kraków, zaś na kolejnej pozycji znalazła się para: łódzkie-Łódź. Warto przyjrzeć się w tym kontekście sytuacji na rynkach: inwestycyjnym, turystycznym i akademickim dla wspomnianych par. 
Tabela 6.11. Syntetyczna miara udziału wszystkich zasobów stolicy w zasobach regionu ogółem

\begin{tabular}{|l|c|c|}
\hline \multicolumn{1}{|c|}{ Województwo } & $\begin{array}{c}\text { Ważony syntetyczny miernik udziału wszystkich } \\
\text { zasobów stolicy w regionie }\end{array}$ & $\begin{array}{c}\text { Miejsce } \\
\text { w rankingu }\end{array}$ \\
\hline Małopolskie & 0,490011 & 1 \\
\hline Łódzkie & 0,47562 & 2 \\
\hline Wielkopolskie & 0,398683 & 3 \\
\hline Lubelskie & 0,382502 & 4 \\
\hline Świętokrzyskie & 0,371278 & 5 \\
\hline Zachodniopomorskie & 0,359246 & 6 \\
\hline Warmińsko-mazurskie & 0,274664 & 7 \\
\hline Podkarpackie & 0,255829 & 8 \\
\hline
\end{tabular}

Źródło: jak do tab. 6.1.

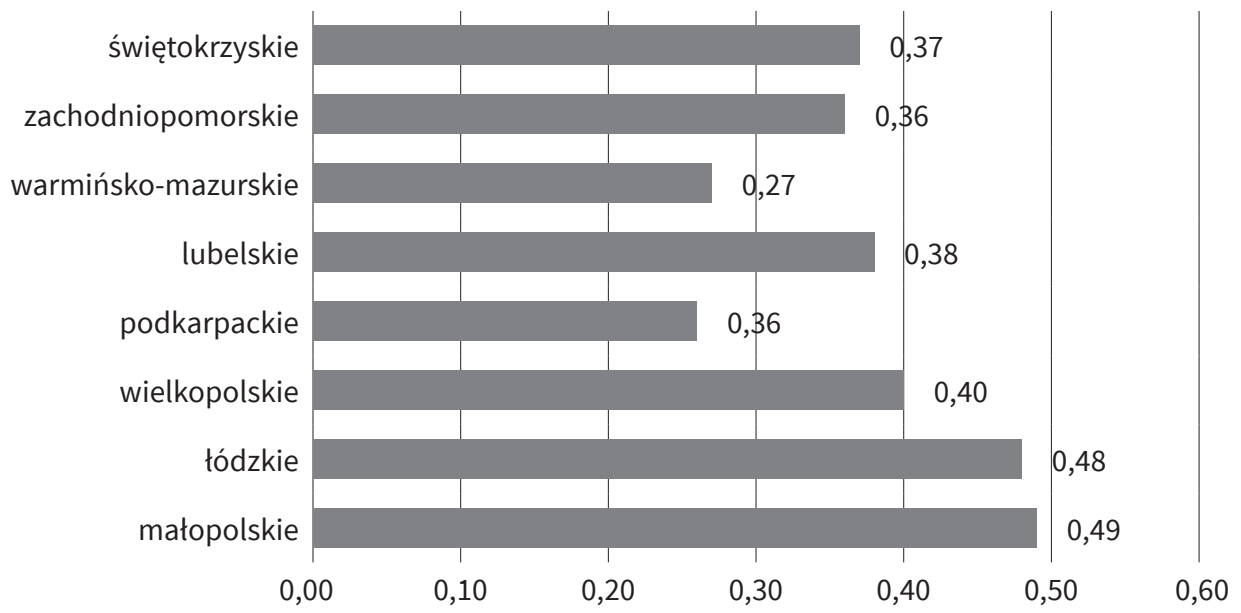

Rys. 6.6. Syntetyczny miernik potencjału udziału wszystkich badanych zasobów stolicy w zasobach regionu ogółem

Źródło: jak do rys. 6.1.

Rynek inwestycyjny został $\mathrm{w}$ badaniu zdefiniowany szeroko, zatem objął obok przedsiębiorstw produkcyjnych również działalność usługową (rynek BPO), w której to Kraków zajmuje pierwszą pozycję w Polsce. Równocześnie górzysta Małopolska nie jest w stanie przekonać inwestorów do lokalizacji inwestycji produkcyjnych, szczególnie w sytuacji bezpośredniej konkurencji ze strony sąsiadującego z nią Górnego Śląska. Stąd udział Krakowa na rynku inwestycyjnym wobec regionu okazał się najwyższy spośród badanych województw. 
Niemal taką samą pozycję posiada w syntetycznym zestawieniu Łódź. Jednak pozycja Łodzi wynika z mieszanego, bo przemysłowo-usługowego, charakteru miasta oraz jego dominującego potencjału na tle województwa. Warto podkreślić, że wśród cech statystycznych przyjętych do konstruowania miernika znalazł się też potencjał lokalnego rynku (20\%), opisywany przy pomocy liczby mieszkańców czy liczby przedsiębiorstw. Oba analizowane tutaj miasta (Kraków i Łódź) posiadają, po Warszawie, najwyższe pod tym względem pozycje w kraju.

W przypadku rynku turystycznego Kraków dominuje nad regionem Małopolski, mimo że ta jest jednym z ważniejszych obszarów recepcji turystycznej w kraju. Choć łódzkie i Łódź są w kontekście turystyki niepodobne do pary: małopolskie-Kraków, to relatywny udział stolicy na tym rynku w regionie okazał się podobny. Zasoby turystyczne w regionie łódzkim, wobec zasobów innych województw są relatywnie skromne, natomiast Łódź, będąca trzecim pod względem wielkości miastem w Polsce, posiada rozwijającą się turystykę miejską z wymiernym udziałem turystyki biznesowej.

Inaczej wygląda sytuacja na rynku akademickim. Statystyki pokazują, że na tym rynku Łódź jest stolicą o relatywnie większej od Krakowa koncentracji funkcji akademickich. Okazuje się bowiem, że inne ośrodki Małopolski, takie jak Nowy Sącz czy Tarnów, w większym stopniu kompensują dominującą pozycję Krakowa niż Piotrków Trybunalski, Sieradz czy Tomaszów Mazowiecki w stosunku do rynku akademickiego w Łodzi.

W wyniku przeprowadzonych obliczeń z wykorzystaniem zaproponowanej metody klasyfikacji otrzymano podział województw według trzech poziomów miernika, który zaprezentowano w tab. 6.12.

Tabela 6.12. Poziomy miernika potencjału stolicy w regionie na rynkach: inwestycyjnym, turystycznym i akademickim ogółem

\begin{tabular}{|l|c|l|}
\hline I - wysoki poziom & $<0,490 ; 0,411)$ & małopolskie, tódzkie \\
\hline II - średni poziom & $<0,411 ; 0,333)$ & $\begin{array}{l}\text { wielkopolskie, świętokrzyskie zachodniopomorskie, } \\
\text { lubelskie, }\end{array}$ \\
\hline III - niski poziom & $<0,333 ; 0,255>$ & warmińsko-mazurskie, podkarpackie \\
\hline
\end{tabular}

Źródło: jak do tab. 6.4 .

Najniższy poziom miernika syntetycznego odnotowano w przypadku par: warmińsko-mazurskie-Olsztyn oraz podkarpackie-Rzeszów, co oznacza, że potencjał stolic tych regionów pod względem atrakcyjności dla inwestorów, turystów i studentów jest relatywnie słabszy. W przypad$\mathrm{ku}$ rynku inwestycyjnego $\mathrm{w}$ obu przypadkach odnotowano relatywnie mniejszy potencjał stolicy w regionie. W ostatnich latach Rzeszów sku- 
tecznie pozycjonuje się jako stolica innowacji, przyciągając do regionu nowe firmy, w tym firmy należące do szeroko rozumianej branży lotniczej. Jednak fakt, że lokalizowane są one w większości poza administracyjnym obszarem miasta Rzeszowa, powoduje, że nie są one widoczne w statystykach po stronie miasta i tym samym umniejszają jego pozycję w regionie.

Na krajowym rynku turystycznym oba regiony posiadają rozpoznawalną ofertę, a ich stolice - ze względu na położenie - mogą stanowić swoiste bramy do regionów. Jak pokazują statystyki, do tej pory nie udało się wykorzystać tego ich potencjału. Biorąc pod uwagę walory środowiskowe zarówno Warmii i Mazur, jak i górskich pasm Podkarpacia należy podkreślić, że trudno jest rozwinąć potencjał turystyczny miast, które takich walorów są pozbawione.

Kierując się metodyką doboru studiów przypadków prezentowaną w rozdziale czwartym, do dalszych badań zakwalifikowano po dwa skrajne przypadki. Przypadki A (o najwyższym potencjale stolicy w regionie) to województwa małopolskie i łódzkie oraz przypadki B (o najniższym potencjale stolicy w regionie) to województwa warmińsko-mazurskie i podkarpackie.

Tabela 6.13. Zestawienie wyników klasyfikacji regionów z wykorzystaniem miary udziału zasobów stolicy w zasobach regionu ogółem na rynkach: inwestycyjnym, turystycznym, akademickim oraz w ujęciu syntetycznym

\begin{tabular}{|c|c|c|c|}
\hline $\begin{array}{c}\text { Zasoby na } \\
\text { kolejnych rynkach }\end{array}$ & III - niski poziom & II - średni poziom & I - wysoki poziom \\
\hline $\begin{array}{l}\text { Zasób rynek } \\
\text { inwestycyjny }\end{array}$ & $\begin{array}{l}\text { warmińsko-mazur- } \\
\text { skie, podkarpackie, }\end{array}$ & $\begin{array}{c}\text { świętokrzyskie, } \\
\text { zachodniopomorskie, } \\
\text { wielkopolskie }\end{array}$ & $\begin{array}{c}\text { małopolskie, tódzkie, } \\
\text { lubelskie }\end{array}$ \\
\hline $\begin{array}{l}\text { Zasoby rynek } \\
\text { turystyczny }\end{array}$ & $\begin{array}{l}\text { świętokrzyskie, za- } \\
\text { chodniopomorskie, } \\
\text { warmińsko-mazur- } \\
\text { skie, podkarpackie }\end{array}$ & $\begin{array}{l}\text { wielkopolskie, } \\
\text { lubelskie }\end{array}$ & małopolskie, tódzkie \\
\hline $\begin{array}{l}\text { Zasoby rynek } \\
\text { akademicki }\end{array}$ & podkarpackie & $\begin{array}{l}\text { warmińsko-mazur- } \\
\text { skie, lubelskie }\end{array}$ & $\begin{array}{l}\text { tódzkie, małopolskie, } \\
\text { wielkopolskie, } \\
\text { świętokrzyskie, } \\
\text { zachodniopomorskie }\end{array}$ \\
\hline $\begin{array}{l}\text { Wszystkie } \\
\text { zasoby }\end{array}$ & $\begin{array}{l}\text { warmińsko-mazur- } \\
\text { skie podkarpackie }\end{array}$ & $\begin{array}{c}\text { wielkopolskie, } \\
\text { świętokrzyskie, } \\
\text { zachodniopomorskie, } \\
\text { lubelskie }\end{array}$ & małopolskie, tódzkie \\
\hline
\end{tabular}

Źródło: jak do tab. 6.1.

Zestawienie wyników klasyfikacji regionów z wykorzystaniem miary udziału zasobów stolicy w zasobach regionu ogółem zaprezentowano w tab. 6.13. Zgodnie z nim stolice województw łódzkiego i małopolskiego 
wykazały wysoki udział w zasobach regionu ogółem na każdym badanym rynku. Natomiast tylko para Rzeszów-podkarpackie wykazała się również konsekwentnie niską pozycją w posiadanych zasobach na tle regionu na wszystkich rynkach. W przypadku rynku akademickiego Olsztyn wykazał udział zasobów na tle regionu na nieco wyższym (średnim) poziomie ze względu na ograniczoną alternatywę dla kształcenia wyższego w warmińsko-mazurskim.

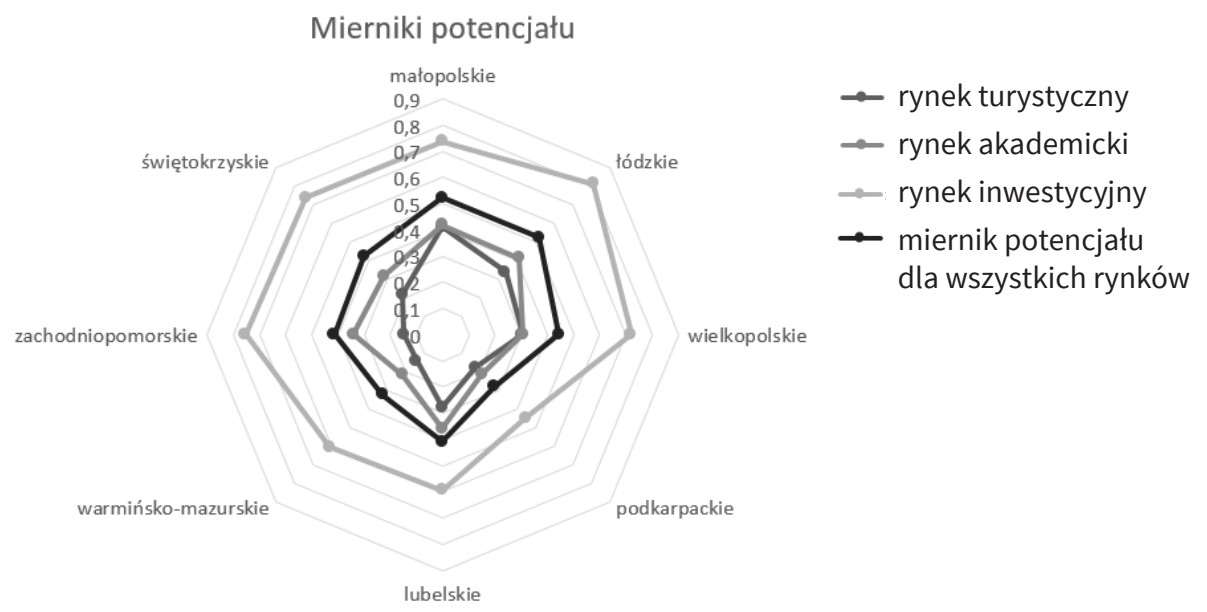

Rys. 6.7. Mierniki potencjału rozumianego jako udział zasobów stolicy w zasobach regionu ogółem

Źródło: jak do rys. 6.1.

Przyjrzyjmy się jeszcze całościowej ocenie zasobów stolicy w kontekście regionów, w których funkcjonują. Interesujących informacji na ten temat dostarcza rys. 6.7 prezentujący mierniki potencjału stolicy w regionie na badanych rynkach. Zdecydowanie największy potencjał posiadają stolice na rynku akademickim, bowiem polską specyfiką jest to, że silne uczelnie funkcjonują w dużych miastach. Jest to model, który wieki temu został przełamany w krajach Europy Zachodniej na rzecz silnych uniwersytetów w małych miasteczkach, dla których funkcja akademicka jest dominująca.

$\mathrm{Na}$ drugim biegunie znajduje się rynek turystyczny, gdzie pozycja stolicy, może za wyjątkiem Krakowa, jest na tle regionu znacznie słabsza. Należy jednak dodać, że inaczej kształtuje się sytuacja na rynku turystyki biznesowej. W tym przypadku znaczenie miasta - stolicy regionu jest pierwszorzędne. Na koniec odnieśmy się do rynku inwestycyjnego. Na rynku tym potencjał stolicy lokuje się pomiędzy rynkiem turystycznym i akademic- 
kim. Należy podkreślić, że statystyka nie uwzględnia faktu, że szereg inwestycji, zwłaszcza tych produkcyjnych, lokowanych jest poza granicami administracyjnymi miast, zaś pracują w nich mieszkańcy tych miast.

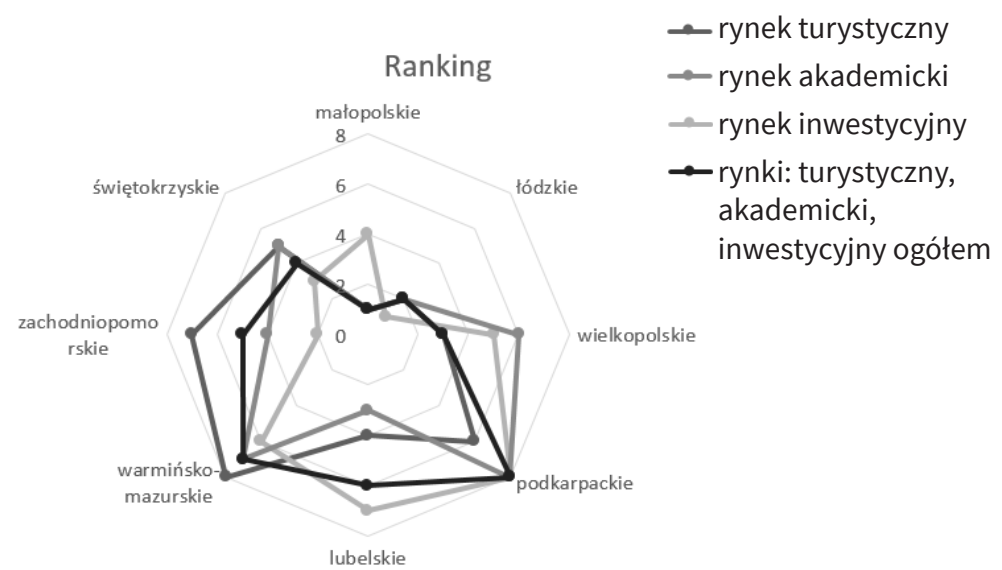

Rys. 6.8. Ranking regionów pod względem udziału zasobów stolicy w zasobach ogółem w regionie według przyjętego miernika na rynkach: inwestycyjnym, turystycznym, akademickim oraz ogółem

Źródło: jak do rys. 6.1.

Interesujące zestawienie umieszczono na rys. 6.8, gdzie odnajdziemy pozycje poszczególnych stolic $\mathrm{w}$ regionach na kolejnych rynkach oraz ogółem. Wyraźnie widać, że relacja Łódź-łódzkie jest niemal identyczna na kolejnych rynkach: inwestycyjnym, turystycznym i akademickim. Na przeciwnym biegunie mamy tu takie pary, jak: Szczecin-zachodniopomorskie i Olsztyn-warmińsko-mazurskie, gdzie pozycja stolicy była inna w odniesieniu do każdego rynku odniesienia.

\subsection{Ocena wspótdziałania pomiędzy regionem a miastem w zakresie realizacji procesów marketingowych}

Wśród podstawowych narzędzi marketingu terytorialnego, zorientowanego na zewnętrznych, potencjalnych użytkowników terytorium, wymienia się: budowanie marki terytorium, nawiązywanie i prowadzenie międzyna- 
rodowych relacji (miasta i regiony partnerskie) czy działania zorientowane na wzmacnianie lokalnego/regionalnego potencjału przedsiębiorczości [Raszkowski 2014]. W badaniu skoncentrowano się na tych instrumentach, które dotyczą równocześnie każdego ze wspomnianych rynków.

\subsubsection{Kryteria oceny $i$ ich wagi}

Dla oceny poziomu współdziałania pomiędzy regionem i stolicą wykorzystano zarówno miary subiektywne, w postaci wypowiedzi menedżerów publicznych badanych urzędów marszałkowskich i urzędów miast - stolic tych regionów, jak i miary obiektywne. W tej drugiej grupie znalazły się takie, jak: podobieństwo logotypów regionów i miast, zgodność kierunków współpracy zagranicznej regionu i stolicy oraz rola stolicy w dyskursie strategicznym regionu. Poszczególne miary zostały zaprezentowane w tab. 6.14 wraz z ich wagami. Przyjęto, że udział czynników jakościowych (opinie respondentów) oraz czynników ilościowych będzie taki sam i wynosić będzie po $50 \%$. Natomiast w każdej z tych grup poszczególne cechy uwzględniono w sposób proporcjonalny.

Tabela 6.14. Cechy i wagi wykorzystane w ocenie współdziałania region-stolica w procesach marketingowych zorientowanych na użytkowników zewnętrznych

\begin{tabular}{|c|c|c|c|c|}
\hline \multicolumn{2}{|c|}{ Ocena subiektywna 50\% } & \multicolumn{3}{c|}{ Ocena obiektywna 50\% } \\
\hline $\begin{array}{c}\text { Ocena wspót- } \\
\text { działania przez } \\
\text { menedżerów } \\
\text { publicznych } \\
\text { badanych regio- } \\
\text { nów }\end{array}$ & $\begin{array}{c}\text { Ocena współ- } \\
\text { działania przez } \\
\text { menedżerów } \\
\text { publicznych } \\
\text { badanych stolic }\end{array}$ & $\begin{array}{c}\text { Podobieństwo } \\
\text { logotypów mia- } \\
\text { sta i regionu }\end{array}$ & $\begin{array}{c}\text { kierunkóćw } \\
\text { współpracy } \\
\text { zagranicznej } \\
\text { (na poziomie } \\
\text { regionu) }\end{array}$ & $\begin{array}{c}\text { Pozycja stolicy } \\
\text { w dyskursie } \\
\text { strategicznym } \\
\text { regionu }\end{array}$ \\
\hline $50 \%$ & $50 \%$ & $33 \%$ & $33 \%$ & $34 \%$ \\
\hline
\end{tabular}

Źródło: jak do tab. 6.1.

\subsubsection{Ocena subiektywna współdziatania dokonana przez menedżerów relacji}

Jak już wspominano w rozdziale czwartym, część jakościowa opisywanych tu badań została zrealizowana w ramach projektu NN115364339 Marketing jako operacyjne rozwinięcie koncepcji governance $w$ zarzadzaniu publicznym współrealizowanego przez autora w latach 2010-2012. Zebrane wtedy opinie respondentów zostały wykorzystane w niniejszym podrozdziale. 
Ocena współdziałania została dokonana na podstawie wywiadów pogłębionych, przeprowadzonych z menedżerami tzw. rynkowych jednostek organizacyjnych (RYN) w badanych urzędach marszałkowskich oraz w urzędach miast (stolic tych regionów). Należy podkreślić, że omawiana kategoria: „rynkowe jednostki organizacyjne OT” składa się z departamentów realizujących funkcje rynkowe/marketingowe i charakteryzujących się mniejszym sformalizowaniem oraz większą swobodą definiowania sposobów realizacji zadań przez menedżerów publicznych stojących na ich czele. Wywiady prowadzone były w ramach szerszego problemu badawczego [Anders-Morawska, Rudolf 2015], natomiast wykorzystany tu wątek relacji został opisany przy pomocy zestawu pytań kierowanych do respondentów (załącznik 6.1).

Wykorzystano tu również wywiady przeprowadzone z pozostałymi (obok miasta - stolicy) interesariuszami instytucjonalnymi regionu, którzy odnosili się do relacji region-miasto i współdziałania pomiędzy tymi organizacjami terytorialnymi. Pozwoliły one na pełniejsze zrozumienie poszczególnych przypadków relacji, jednak nie zostały włączone do materiału podlegającego ocenie.

Ostatecznie dla przypadku A (zasoby stolicy relatywnie wysokie) wykorzystano 11 wywiadów, z których 6 przeprowadzono w Krakowie (UM i UMK), a 5 w Łodzi (UM i UMŁ). Natomiast dla przypadku B (zasoby stolicy relatywnie niskie) wykorzystano 9 wywiadów, z których 5 zrealizowano w Olsztynie (UM i UMO), a 4 w Rzeszowie (UM i UMR). Respondenci dokonywali oceny współdziałania w skali od (-3) do (-1) dla ocen negatywnych oraz od 1 do 3 dla ocen pozytywnych. W przypadku braku jednoznacznej odpowiedzi przyjęto 0 . W wyniku analizy materiału badawczego uzyskano oceny poszczególnych relacji, które umieszczono w tab. 6.15.

Tabela 6.15. Ocena współdziałania region-miasto przez badanych menedżerów publicznych z urzędów marszałkowskich oraz urzędów miast w zakresie realizacji procesów marketingowych

\begin{tabular}{|l|l|c|c|c|}
\cline { 2 - 5 } \multicolumn{1}{c|}{} & \multicolumn{1}{c|}{ Region } & $\begin{array}{c}\text { Średnia } \\
\text { ocena }\end{array}$ & Miasto & $\begin{array}{c}\text { Średnia } \\
\text { ocena }\end{array}$ \\
\hline \multirow{2}{*}{ Przypadek A } & małopolskie & 2,00 & Kraków & 2,00 \\
\cline { 2 - 5 } & tódzkie & 1,50 & Łódź & 1,33 \\
\hline \multirow{2}{*}{ Przypadek B } & warmińsko-mazurskie & 0,33 & Olsztyn & 0,50 \\
\cline { 2 - 5 } & podkarpackie & 1,00 & Rzeszów & 1,00 \\
\hline
\end{tabular}

Źródło: badania własne. 
Respondenci niemal we wszystkich przypadkach dokonali pozytywnej oceny relacji region-miasto, $\mathrm{w}$ kontekście prowadzonych przez region procesów marketingowych. Występują jednak spore różnice między poszczególnymi województwami. Dla przypadku A, gdzie rola stolicy w regionie jest większa, poziom współdziałania oceniono relatywnie wyżej (odpowiednio średnie oceny 2,00 i 1,415), natomiast w przypadku B oceny takie były relatywnie niższe (odpowiednio $1,00 \mathrm{i} 0,415$ ).

Przybliżymy obecnie opinie respondentów z przypadku A (małopolskie, łódzkie), dotyczące relacji region-miasto. Należy podkreślić, że wszyscy respondenci z obu tych województw potwierdzają dominującą pozycję stolicy w gospodarce regionu. Spośród wszystkich badanych par: region-stolica, najwyżej oceniona została relacja Małopolska-Kraków (2,00 przez menedżerów marszałkowskich i 2,00 przez menedżerów miejskich). W przypadku tej relacji wymieniano liczne przykłady współpracy zarówno na szczeblu strategicznym, jak i operacyjnym. Ważne według respondentów z Krakowa jest to, że inicjatywa wypływa $z$ obu stron, że partnerzy są zbliżeni do siebie potencjałem i żaden $\mathrm{z}$ nich nie dominuje. Obszerne wypowiedzi respondentów z Małopolski i Krakowa dają podstawy do sformułowania wniosku, że o wartości relacji decydują obie zainteresowane strony, a więc zarówno region, jak i miasto, a dopiero wówczas może to doprowadzić (w długim okresie) do trwałego partnerstwa. Nie musi to mieć odzwierciedlenia w instytucjach formalnych w postaci umów, porozumień czy listów intencyjnych. W przypadku pary łódzkie-Łódź również oceny współdziałania obu stron relacji są do siebie zbliżone (odpowiednio oceny: 1,50 i 1,33).

Przechodząc do przypadku B, gdzie zidentyfikowano relację regionmiasto $\mathrm{w}$ dwóch województwach (warmińsko-mazurskim i podkarpackim), opinie na temat współdziałania w kontekście prowadzonych działań marketingowych są pozytywne, chociaż ocena wspomnianej relacji jest tu bardziej surowa, zwłaszcza w przypadku województwa warmińsko-mazurskiego i Olsztyna. Generalnie respondenci opisujący tę relację wykazali się dużą oszczędnością w wypowiedziach i w niewielkim zakresie uzasadniali mierne oceny tej relacji. Natomiast respondenci z podkarpackiego urzędu marszałkowskiego wskazywali, że ich rolą jest dbanie o cały region, a nie tylko o rozwój stolicy. Świadczą o tym dwie poniższe wypowiedzi: Nasza sfera działalności nie jest typowo ukierunkowana na miasto, tylko szerzej na rozwój regionu. Działamy obok, ponieważ mamy szersze spektrum działalności. Sa agencje które są stricte miejskie. Natomiast nasze spektrum działalności jest szersze niż tylko miasto. Faktycznie w takiej wypowiedzi można odnaleźć bardziej formalny stosunek do relacji z miastem, co na pewno nie sprzyja budowaniu więzi współpracy pomiędzy oboma podmiotami. W przypadku województwa podkarpackiego i Rzeszowa obie strony oceniły wzajemne współdziałanie podobnie (ocena 1). Z wypowiedzi wynika 
też, że w ostatnich latach relacja ta ulega poprawie, choć nadal oceny te pozostają na niższym poziomie niż w obu przypadkach A.

W zebranym materiale empirycznym można odnaleźć szereg stwierdzeń, które mają charakter rekomendacji i rad doświadczonych respondentów, formułowanych na temat współdziałania pomiędzy regionem i miastem. Rekomendacje te dotyczą m.in. podziału obowiązków pomiędzy partnerami, elastyczności prowadzonej współpracy czy potrzeby budowania relacji w długim okresie, by stawały się partnerskie.

\subsubsection{Miary obiektywne współdziałania}

\section{Podobieństwo logotypów regionu i miasta}

Działania marketingowe JST w dużej mierze wizualizują się poprzez czynności w zakresie komunikowania się z konkretnymi grupami docelowymi oraz działania szersze, zorientowane na budowanie ogólnego wizerunku terytorium. Należy podkreślić, że właśnie znak - logo regionu czy miasta jest podstawowym elementem przyjętego systemu identyfikacji wizualnej, instrumentem kształtowania wizerunku. Każdy z badanych regionów oraz miast posiada herb, będący formalnym oznaczeniem terytorium. Natomiast dla działań operacyjnych tworzone są specjalne znaki, nawiązujące do współczesnych walorów miast czy regionów oraz przyjętego kierunku budowania wizerunku. Logotypy badanych regionów i miast umieszczono w tab. 6.16.

W badaniu przyjęto, że podobieństwo logo regionu i logo miasta stanowi optymalną sytuację, bowiem nawet prowadzone odrębnie działania wizerunkowe miasta i regionu mogą wpływać na podobne pozycjonowanie obu terytoriów. Należy również zaznaczyć, że w większości przypadków obecne znaki miast powstawały wcześniej niż znaki województw, co w przypadku ich zgodności świadczy o tym, że to województwa chciały uwzględnić znak stolicy $\mathrm{w}$ tworzonym przez siebie znaku. Poniżej prezentujemy zestawienia logotypów badanych par miast i regionów.

Oceny podobieństwa znaków dokonywano w skali $0-3$, gdzie 0 oznacza kompletny brak podobieństwa, natomiast 1 - niskie podobieństwo, 2 - średnie, 3 - wysokie podobieństwo. Oceny podobieństwa poszczególnych par znaków dokonano z uwzględnieniem takich kryteriów, jak: kształt, kolor, typografia, motyw. W przypadku Małopolski i Krakowa logotypy oceniono jako „mało podobne” (1). Niewątpliwie za taką oceną przemawiają: różnice $\mathrm{w}$ kształcie, typografii. Za element podobny $\mathrm{w}$ obu znakach można uznać jedynie kolor. 
Tabela 6.16. Logotypy badanych województw i miast w okresie realizacji badania

\begin{tabular}{|c|c|c|c|c|c|}
\hline 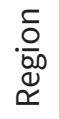 & Logo regionu & $\begin{array}{c}\text { Logo stolicy } \\
\text { regionu }\end{array}$ & 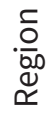 & Logo regionu & $\begin{array}{l}\text { Logo stolicy } \\
\text { regionu }\end{array}$ \\
\hline $\begin{array}{l}\frac{0}{2} \\
\frac{0}{0} \\
\frac{0}{0}\end{array}$ & Łódzki & KREUSE & $\begin{array}{l}\frac{0}{x} \\
\frac{\text { v }}{0} \\
\frac{0}{0} \\
\frac{0}{\frac{0}{\varepsilon}}\end{array}$ & Matopolska & $\begin{array}{l}\text { KRA } \\
\text { KOWW } \\
\text { k r a k ow - p } 1\end{array}$ \\
\hline $\begin{array}{l}\frac{0}{x} \\
\frac{0}{0} \\
\frac{0}{0} \\
\frac{0}{\pi} \\
\frac{0}{0} \\
\frac{0}{0} \\
0\end{array}$ & $\overbrace{P O D K A R P A C K I E}$ & $\Rightarrow \underset{\text { stolica innor }}{\operatorname{rZeSZC}}$ & 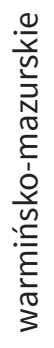 & $\begin{array}{l}\text { WARMUA } \\
\text { MAZVRY }\end{array}$ & OLSZTYN \\
\hline
\end{tabular}

Źródło: strony WWW badanych podmiotów.

W przypadku miasta Łodzi i województwa łódzkiego sytuacja jest złożona, bowiem w okresie realizacji badania zmieniło się logo województwa. O ile wcześniejsze logo, funkcjonujące aż kilkanaście lat, charakteryzowało się cechami podobieństwa do logo miasta, to od $2013 \mathrm{r}$., kiedy wprowadzono nowe logo regionu istniejące między nimi różnice są znaczne. W związku jednak z faktem, że badania prezentowane w niniejszej monografii obejmują okres 2009-2014, zdecydowano się na przyjęcie do porównań poprzedniego znaku. Porównując logotypy łódzkiego i Łodzi, oceniono je jako „średnio podobne” (2). Na wynik ten wpłynął fakt zbieżności kolorów. Natomiast koncepcja obu znaków i zastosowane tam motywy nawiązują do sztuki nowoczesnej okresu międzywojennego w wykonaniu pary artystów: Katarzyny Kobro (logo regionu) i Władysława Strzemińskiego (logo miasta).

Dwie kolejne pary region-miasto reprezentują przypadek B. W logo warmińsko-mazurskiego i Olsztyna można odnaleźć wspólny symbol słońca. Występuje też pewna zbieżność ogólnego przesłania (symbolika związana z wypoczynkiem). Elementem różnicującym oba znaki jest za- 
stosowanie zupełnie innej typografii. Biorąc pod uwagę powyższe fakty, oceniono podobieństwo obu znaków na poziomie (1) - niskie podobieństwo. W przypadku Podkarpacia i Rzeszowa trudno zaobserwować jakiekolwiek zbieżności. Jest to o tyle zaskakujące, że w wypowiedziach respondentów deklarowano współpracę w zakresie działań marketingowych. Podobieństwo obu znaków oceniono na poziomie 0 (brak jakiegokolwiek podobieństwa).

\section{Zgodność kierunków współpracy zagranicznej}

Należy przyjąć, że relacje międzynarodowe województw są jednym z podstawowych instrumentów marketingu terytorialnego i mogą mieć wymierny wpływ na pozyskiwanie z zagranicy inwestycji, turystów oraz studentów [Raszkowski 2014]. Ostateczną decyzję o podpisaniu listu intencyjnego czy umowy o współpracy podejmują organy stanowiące samorządów terytorialnych - odpowiednio sejmik województwa i rada miejska. Jednak, jak powszechnie wiadomo, to struktury organizacyjne w postaci samorządowych urzędów odgrywają kluczową rolę w inicjowaniu tych relacji, a następnie $\mathrm{w}$ ich realizacji, dlatego ich zaistnienie należy wiązać $\mathrm{z}$ aktywnością OT rozumianej tu jako menedżerów i pracowników liniowych.

Należy podkreślić, że miasta partnerskie polskich stolic województw to formuła istniejąca od kilkudziesięciu lat, choć po przemianach w $1989 \mathrm{r}$. listy miast partnerskich zostały zrewidowane $\mathrm{z}$ uwzględnieniem nowych potrzeb i kierunków rozwoju. Nowsze relacje zagraniczne mają natomiast samorządy województw, istniejące krócej (od początku 1999 r.). Regiony i miasta mogą kształtować te relacje niezależnie, ale jest rzeczą oczywistą, że jeżeli relacja region polski-region partnerski za granicą będzie uzupełniona partnerstwem ich stolic, to zwiększą się więzi obu regionów i możliwości pozyskiwania z nich zasobów na rzecz rozwoju macierzystego regionu. Przyjęto, że powyższa zgodność będzie oceniana na poziomie regionu.

Wszystkie cztery regiony, które zostały zakwalifikowane do analizy, posiadają rozbudowane relacje zagraniczne, podobnie ich stolice. Natomiast ich kierunki są już bardziej zróżnicowane. Należy podkreślić, że najwięcej bo aż 6 zgodnych kierunków współpracy partnerskiej (zgodność na poziomie regionu) posiada województwo podkarpackie i Rzeszów. Na drugim miejscu pod względem zgodności znalazło się województwo łódzkie i Łódź z 5 takimi kierunkami. Oba te województwa charakteryzuje podobny rozkład kierunków współpracy zagranicznej. Podobnie układają się tam również proporcje regionów partnerskich w Europie Zachodniej i w Europie Wschodniej. Natomiast województwo małopolskie i Kraków posiadają zaledwie 3 wspólne kierunki współpracy zagranicznej. Najmniej przypadków zgodności posiada województwo warmińsko-mazurskie i Olsztyn, bo zaledwie 2. 
W tab. 6.17 zamieszczono informacje dotyczące kierunków współpracy badanych województw z zagranicą $\mathrm{w}$ ujęciu ilościowym. Natomiast nazwy regionów i miast partnerskich, które spełniły kryterium zgodności, zostały umieszczone w załączniku 6.2.

Tabela 6.17. Miasta i regiony partnerskie badanych województw i miast w ujęciu ilościowym

\begin{tabular}{|c|c|c|c|c|c|c|}
\hline \multirow[b]{2}{*}{ Region/stolica } & \multirow[b]{2}{*}{$\begin{array}{c}\text { Liczba } \\
\text { partne- } \\
\text { rów }\end{array}$} & \multicolumn{4}{|c|}{ Strefa świata } & \multirow{2}{*}{$\begin{array}{l}\text { Zgodność } \\
\text { regionu part- } \\
\text { nerskiego } \\
\text { z miastem } \\
\text { partnerskim } \\
\text { stolicy }\end{array}$} \\
\hline & & $\begin{array}{c}\text { Europa } \\
\text { Zachodnia }\end{array}$ & $\begin{array}{l}\text { Europa } \\
\text { Środkowa }\end{array}$ & $\begin{array}{c}\text { Europa } \\
\text { Wschodnia }\end{array}$ & $\begin{array}{c}\text { inne } \\
\text { kontynenty }\end{array}$ & \\
\hline Łódzkie & 15 & 6 & 2 & 6 & 1 & \multirow{2}{*}{5} \\
\hline Łódź & 20 & 7 & 2 & 5 & 6 & \\
\hline Małopolskie & 17 & 7 & 5 & 2 & 3 & \multirow{2}{*}{3} \\
\hline Kraków & 41 & 18 & 8 & 6 & 9 & \\
\hline Podkarpackie & 21 & 5 & 8 & 7 & 1 & \multirow{2}{*}{6} \\
\hline Rzeszów & 12 & 3 & 3 & 3 & 3 & \\
\hline $\begin{array}{l}\text { Warmińsko- } \\
\text { mazurskie }\end{array}$ & 15 & 8 & 4 & 2 & 1 & \multirow[t]{2}{*}{2} \\
\hline Olsztyn & 9 & 5 & 1 & 2 & 1 & \\
\hline
\end{tabular}

Źródło: opracowanie własne na podstawie danych pozyskanych od urzędów marszałkowskich i urzędów miejskich.

\section{Pozycja stolicy w dyskursie strategicznym regionu}

Teksty dokumentów strategicznych i operacyjnych są przygotowywane przez pracowników organizacji terytorialnej. Firmy konsultingowe, niekiedy angażowane przez poszczególne samorządy, koncentrują się raczej na koordynowaniu procesów wypracowywania strategicznej wizji rozwoju, struktury celów bądź narzędzi. Zawarty w nich język jest zatem językiem danej grupy pracowników samorządowych, tworzących organizację terytorialną. Wnikliwa analiza ich treści pozwala zaobserwować określone postawy danej grupy m.in. wobec miasta będącego stolicą regionu. $\mathrm{Z}$ opracowań tych można wyciągnąć wnioski, co do pozycji stolicy w dyskursie strategicznym regionu. Przyjęto, że miarą takiej pozycji będzie częstość pojawiania się nazwy stolicy w strategiach rozwoju województw, które obowiązywały $\mathrm{w}$ badanych regionach $\mathrm{w}$ minionym okresie programowania (2007-2013). Z badania wyłączono nazwy stolic, które pojawiały się w tekście $\mathrm{w}$ nazwach własnych różnych podmiotów oraz $\mathrm{w}$ znaczeniu niezwiązanym ze stolicą regionu. Informacje na ten temat zestawiono w tab. 6.18. 
Tabela 6.18. Nazwy miast - stolic województw w dokumentach strategicznych i operacyjnych dotyczących rozwoju poszczególnych województw

\begin{tabular}{|c|c|c|c|}
\hline $\begin{array}{c}\text { Stolica } \\
\text { województwa }\end{array}$ & $\begin{array}{c}\text { Poszukiwane słowo } \\
\text { odnoszące się } \\
\text { do nazwy stolicy } \\
\text { województwa }\end{array}$ & $\begin{array}{l}\text { Suma poszukiwanych } \\
\text { terminów użytych } \\
\text { w bezpośrednim } \\
\text { odniesieniu do stolicy } \\
\text { województwa }\end{array}$ & $\begin{array}{c}\text { Dokument } \\
\text { strategiczny/ } \\
\text { operacyjny regionu }\end{array}$ \\
\hline $\begin{array}{l}\text { Kraków } \\
\text { (MAŁOPOLSKA) }\end{array}$ & $\begin{array}{l}\text { „Krak” } \\
\text { „Krak” }\end{array}$ & $\begin{array}{l}16 \\
115\end{array}$ & $\begin{array}{l}\text { RPO 2014-2020 } \\
\text { SRWM na lata 2011- } \\
2020\end{array}$ \\
\hline $\begin{array}{l}\text { Łódź } \\
\text { (ŁÓDZKIE ) }\end{array}$ & $\begin{array}{l}\text { „Łódź” ; „Łódz”; } \\
\text { „Łodzi” } \\
\text { „Łódź” ; „Łódz”; } \\
\text { „Łodzi” }\end{array}$ & $\begin{array}{l}14 \\
85\end{array}$ & $\begin{array}{l}\text { RPO 2014-2020 } \\
\text { SRWŁ } 2020\end{array}$ \\
\hline $\begin{array}{l}\text { Rzeszów } \\
\text { (PODKARPACKIE) }\end{array}$ & $\begin{array}{l}\text { „Rzesz” } \\
\text { „Rzesz” }\end{array}$ & $\begin{array}{l}25 \\
76\end{array}$ & $\begin{array}{l}\text { RPO 2014-2020 } \\
\text { SRWP } 2020\end{array}$ \\
\hline $\begin{array}{l}\text { Olsztyn } \\
\text { (WARMIŃSKO- } \\
\text { MAZURSKIE) }\end{array}$ & $\begin{array}{l}\text { „Olszty” } \\
\text { „Olszty” }\end{array}$ & $\begin{array}{l}20 \\
30\end{array}$ & $\begin{array}{c}\text { RPO 2014-2020 } \\
\text { SRWWM do roku } 2025\end{array}$ \\
\hline
\end{tabular}

Źródło: jak do tab. 6.1.

Podczas analizy dyskursu planowano posłużenie się dwoma rodzajami dokumentów - strategiami rozwoju województw, które powstawały w latach 2011-2013, czyli w okresie prowadzenia badań empirycznych oraz Regionalnymi Programami Operacyjnymi 2014-2020, które były tworzone w latach 2013-2014, czyli również w okresie realizacji badań. Należy zaznaczyć, że o ile w strategiach nazwy stolic regionów pojawiały się relatywnie często, to w RPO niemal nie występowały. Tłumaczyć to można w ten sposób, że RPO jest dokumentem, który jest przyjmowany przez Komisję Europejską, zatem podlega ocenie zewnętrznej. Faworyzowanie w nim jednej z wielu lokalnych JST mogłoby być zakwestionowane przez tę instytucję. Natomiast dokument nadrzędny - strategia rozwoju, jest paradoksalnie bardziej elastyczny i władze regionu posiadają w tym przypadku większe możliwości budowania tego dokumentu według własnego przekonania.

W RPO nazwy stolicy pojawiały się nader rzadko i kształtowały się w poszczególnych województwach w następujący sposób: podkarpackie (25), warmińsko-mazurskie (20), małopolskie (16), łódzkie (14). Autor uznając, że w przypadku tego dokumentu użycie nazwy stolicy jest poddane ograniczeniom, ze względu na mocno przestrzegane zasady 
niewyróżniania żadnej z lokalnych JST, zdecydował się nie wykorzystywać tych danych do oceny dyskursu.

W strategiach rozwoju najczęściej faworyzowany był Kraków (115 wskazań) oraz Łódź (85). Natomiast w strategiach podkarpackiego i warmińsko-mazurskiego nazwa taka pojawiała się odpowiednio 76 i 30 razy. Powyższe wyniki wskazują, że np. Kraków pojawiał się w strategii Małopolski czterokrotnie częściej niż Olsztyn w strategii województwa warmińsko-mazurskiego. Świadczy to o wyraźnie innej pozycji stolicy w regionie, czego świadomość jest udziałem osób przygotowujących ten dokument. Pozycja Łodzi i Rzeszowa w tym swoistym rankingu jest podobna.

\subsection{Zestawienie wyników badań $\mathrm{i}$ ich interpretacja}

Opierając się na analizowanych wcześniej danych subiektywnych i obiektywnych, dotyczących poziomu współdziałania pomiędzy regionem i miastem w wymiarze organizacyjnym, dokonano całościowej oceny współpracy regionu z miastem - stolicą województwa w kontekście prowadzonych przez region procesów marketingowych zorientowanych na przyciąganie mobilnych czynników wzrostu. Na rys. 6.9 na osi X odłożono opinie respondentów - menedżerów publicznych (50\% z urzędów marszałkowskich i $50 \%$ z urzędów miast). Natomiast na osi Y odłożono miernik wybranych rezultatów współdziałania w postaci: oceny podobieństwa logo regionu i jego stolicy, zgodności kierunków współpracy zagranicznej województw i ich stolic oraz pozycji stolicy w dyskursie strategicznym regionu. Warto zauważyć, że opinie o współdziałaniu region-miasto były bardziej pozytywne niż miary obiektywne w postaci przejawów współdziałania odpowiednio w obu skrajnych przypadkach (A i B).

Należy zwrócić uwagę na bliską lokalizację par: małopolskie-Kraków oraz łódzkie-Łódź na rys. 6.9. Świadczy to o tym, że pomimo oczywistych różnic $\mathrm{w}$ potencjałach tych regionów i miast $\mathrm{w}$ wymiarach: inwestycyjnym, turystycznym czy akademickim, to w relatywnym udziale zasobów stolicy w zasobach regionu ogółem oraz w ocenie tych relacji przez uczestniczących w nich menedżerów publicznych, jest niemal identyczna. Potwierdza to trafność zakwalifikowania obu par do skrajnego przypadku A, gdzie stolica ma relatywnie większe znaczenie $\mathrm{w}$ regionie. 


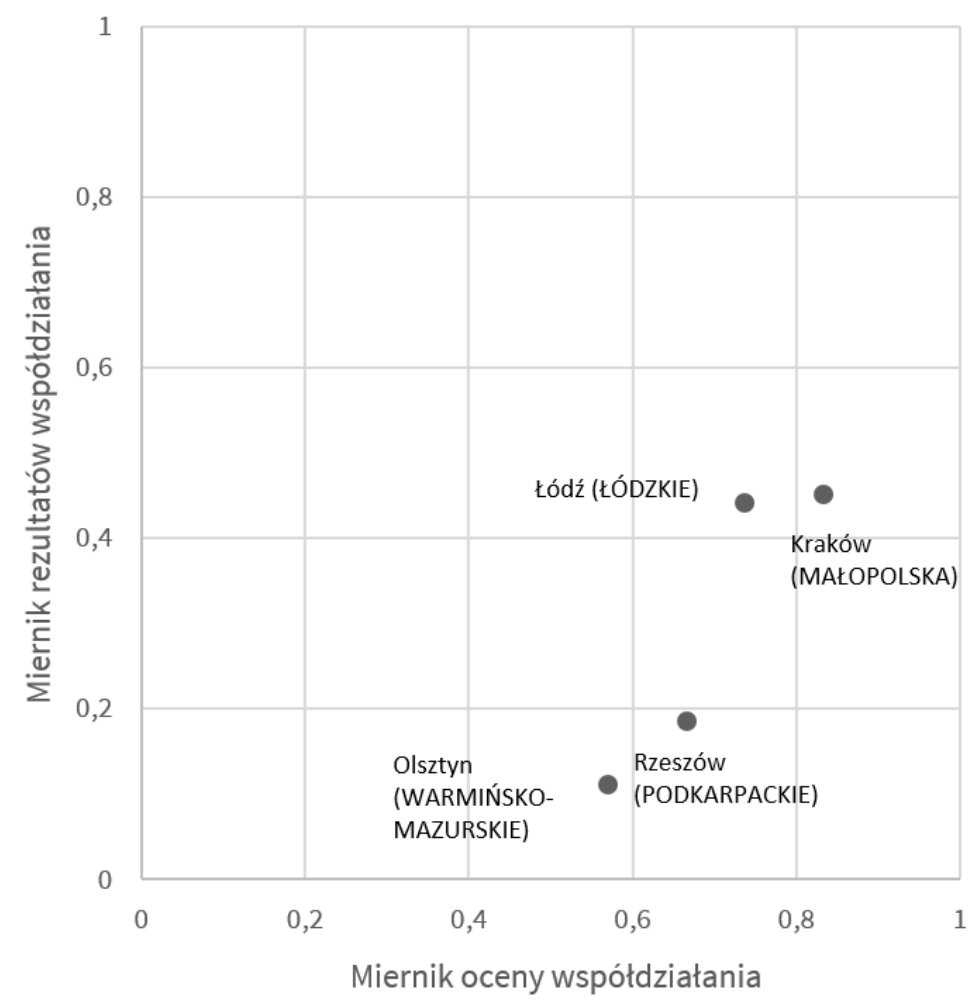

Rys. 6.9. Zestawienie miernika opinii menedżerów oceniających współdziałanie regionu z miastem oraz miernika dotyczącego wybranych rezultatów współdziałania

Źródło: jak do rys. 6.1.

Jeżeli natomiast chodzi o pary, które zaliczono do drugiej skrajności, czyli przypadków o relatywnie mniejszej roli stolicy w regionie (przypadek B), to zaobserwowano tu również zbieżność obu par, chociaż w nieco mniejszym stopniu niż w przypadku A. Widać to dokładniej na rys. 6.10, gdzie oszacowano poziom współdziałania region-miasto w kontekście prowadzonych przez region działań marketingowych z wykorzystaniem cech i wag zaprezentowanych w tabeli 6.14. Nieco wyżej została oceniona relacja podkarpackie-Rzeszów i z wypowiedzi respondentów można było wysnuć wniosek, że poziom współdziałania na linii regionmiasto stopniowo się poprawia. Natomiast relacja warmińsko-mazurskie-Olsztyn została oceniona przez respondenta mniej pozytywnie, bez symptomów świadczących o tym, że sytuacja ulegnie pozytywnej zmianie. Nieco większe różnice pomiędzy oboma parami odnotowano natomiast $\mathrm{w}$ przypadku cech obiektywnych odłożonych na osi Y (rys. 6.9). Tu para podkarpackie-Rzeszów została oceniona wyżej. Tym niemniej 
nadal odległości pomiędzy oboma parami reprezentującymi przypadek B są dużo mniejsze niż odległości każdej z tych par do przypadków A, co świadczy o tym, że wcześniejsza klasyfikacja była uzasadniona.

Miara potencjału zgodności

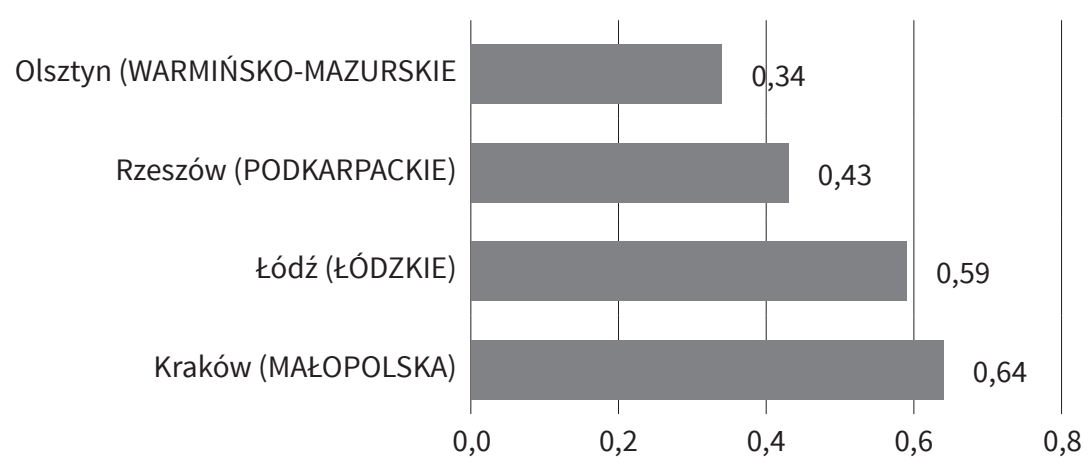

Rys. 6.10. Miara potencjału zgodności łącznie dla subiektywnej oceny dokonanej przez menedżerów i obiektywnych rezultatów współdziałania

Źródło: jak do rys. 6.1.

Obecnie przystąpimy do weryfikacji sformułowanej w rozdziale czwartym hipotezy badawczej (H1b). Dotyczy ona związku pomiędzy udziałem zasobów stolicy w zasobach ogółem regionu a poziomem współdziałania pomiędzy regionem a miastem stanowiącym jego stolicę, a także intensywnością takiego współdziałania. Na rys. 6.11 zaprezentowano zestawienie miernika potencjału wszystkich zasobów miasta $\mathrm{w}$ zasobach regionu ogółem w ujęciu syntetycznym oraz miernika zgodności oceny współdziałania.

Województwo łódzkie jest interesującym przykładem na to, że pomimo wymiernych różnic na poziomie politycznym, a także w sytuacji występowania strukturalnych konfliktów pomiędzy oboma jednostkami terytorialnymi, udaje się efektywnie współdziałać na poziomie operacyjnym. Świadczą o tym relatywnie pozytywne wypowiedzi respondentów obu stron (menedżerów OT na poziomie regionu oraz ich odpowiedników w mieście). Dowodzi tego również poziom zgodności kierunków międzynarodowej współpracy regionu i jego stolicy, czy dyskurs strategiczny zaobserwowany w treści dokumentów strategicznych regionu. $\mathrm{Na}$ tle tych pozytywnych zjawisk pewien dysonans stanowi niezgodność nowego logotypu regionu z logotypem miasta, chociaż tego faktu nie odnotowano w materiale empirycznym, na podstawie którego poczyniono kalkulacje. 
W przypadku województwa małopolskiego sytuacja wynikowa jest podobna, bo prowadzi do wniosku, że mimo drobnych różnic udaje się współpracować. Kraków wydaje się w pewnych obszarach dla Małopolski trudnym partnerem, co daje się odczuć, np. obserwując struktury wojewódzkie, powołane dla rozwoju rynku turystycznego. Kraków należy co prawda do Małopolskiej Organizacji Turystycznej, ale jego bardzo silna pozycja na tym rynku powoduje, że nie jest zainteresowany angażowaniem się w rozwój turystyki w całym regionie. Świadczyć o tym może brak przedstawiciela Krakowa w zarządzie tej organizacji w okresie prowadzenia badania. Natomiast płacona składka Krakowa była wówczas na poziomie niewspółmiernym do korzyści, jakie rynek turystyczny przysparza stolicy Małopolski.

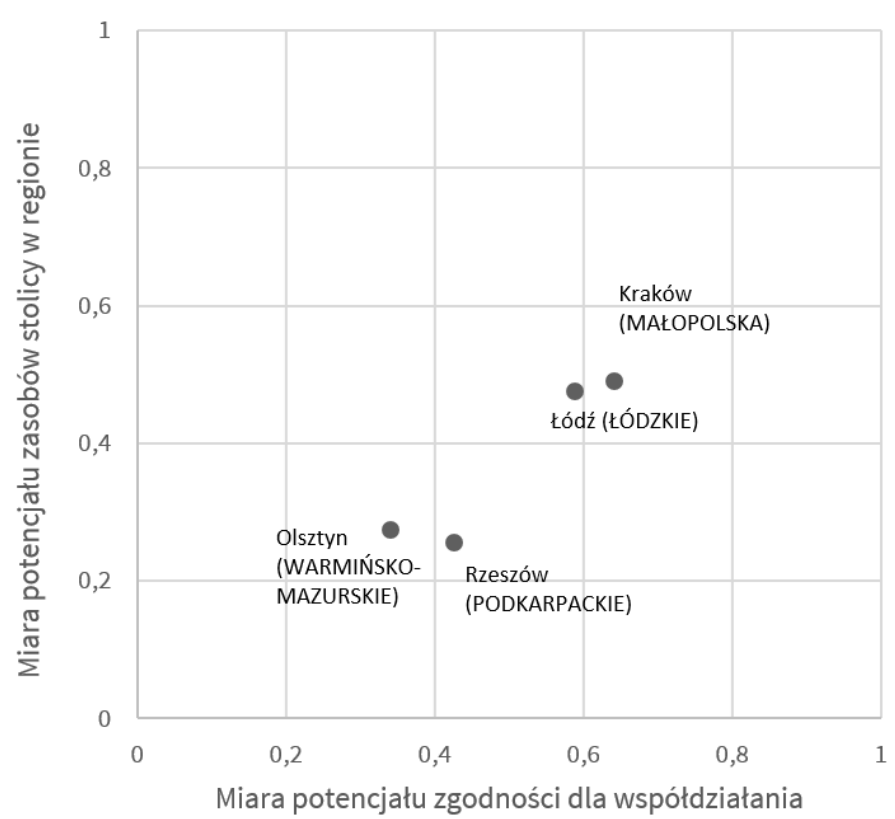

Rys. 6.11. Zestawienie mierników potencjału wszystkich zasobów miasta w zasobach regionu ogółem w ujęciu syntetycznym oraz miernika zgodności subiektywnej oceny i obiektywnych rezultatów współdziałania

Źródto: jak do rys. 6.1.

Należy podkreślić, że respondenci obu badanych stron deklarują współpracę na różnych rynkach i różnych płaszczyznach. Jest ona oceniana generalnie pozytywnie, zaś zaobserwowane mankamenty, w opinii 
badanych menedżerów, można stosunkowo łatwo usunąć. Dość dobrze wypada zgodność wybranych kryteriów, poprzez które mierzono współdziałanie w procesach pozyskiwania inwestorów, turystów i studentów. Podobieństwo logotypów miasta i regionu oceniono na niskim poziomie. Kraków nadspodziewanie często pojawia się w dyskursie strategicznym województwa, a część kierunków relacji międzynarodowych jest zgodna z kierunkami Małopolski. Zatem obie pary region-miasto, które zostały zakwalifikowane do przypadku A, uzyskały podobną pozycję w zestawieniu miernika potencjału zasobów stolicy $\mathrm{w}$ regionie oraz miernika potencjału zgodności dla współdziałania. Świadczy to o bliskości punktów, jakimi na rys. 6.11 oznaczono obie pary stanowiące przypadki A.

Województwo podkarpackie i miasto Rzeszów wykazują już relatywnie niższe oceny poziomu współdziałania, zarówno jeżeli chodzi o wypowiedzi respondentów, jak i fakty w postaci wybranych, obiektywnych rezultatów współdziałania. Najsłabsze relacje region-miasto wykazano w przypadku województwa warmińsko-mazurskiego i Olsztyna. Tu respondenci jasno wyrażali swoje opinie, zwracając uwagę na napięte relacje pomiędzy obiema stronami oraz brak porozumienia wynikający z różnicy interesów. Prawie nie zaobserwowano symptomów współdziałania, które można zinterpretować jako efekty pozytywne. Znaki są mało podobne i nawiązują do siebie jedynie tematyką. Województwo warmińsko-mazurskie posiada tylko 2 zgodne kierunki współpracy zagranicznej. Natomiast w dyskursie strategicznym warmińsko-mazurskiego zaobserwowano najmniejsze natężenie nazwy stolicy, co można interpretować, że Olsztyn ma drugorzędne znaczenie dla regionu.

Określając wpływ wielkości zasobów stolicy w zasobach regionu ogółem na poziom współdziałania regionu $\mathrm{z}$ miastem $\mathrm{w}$ marketingowych procesach pozyskiwania mobilnych czynników wzrostu, zrealizowano sformułowany w rozdziale czwartym cel dla tego etapu badań (C1b). W świetle powyższych rozważań można ogólnie stwierdzić, że wielkość zasobów stolicy regionu wpływa pozytywnie na poziom współdziałania regionu $z$ miastem. Świadczy o tym lokalizacja punktów na rys. 6.11. Pary warmińsko-mazurskie - Olsztyn oraz podkarpackie - Rzeszów znalazły się bliżej środka układu współrzędnych. Natomiast pary: małopolskie - Kraków i łódzkie - Łódź znalazły się dalej w obu opisywanych na osiach wymiarach. Tym samym została zweryfikowana hipoteza H1b. Z prowadzonych przez autora badań wynika, że im większymi zasobami dysponuje stolica regionu w stosunku do zasobów regionu ogółem, tym poziom współdziałania na linii region-stolica jest wyższy. 


\section{Zakończenie}

W ostatnich latach problematyka rozwoju sektora publicznego cieszy się rosnącym zainteresowaniem badaczy. Dynamiczne zmiany w otoczeniu tego sektora oraz wymierne dla niego wsparcie ze strony funduszy unijnych wpływają na szybki jego rozwój. Zmiany zachodzą również w sposobie zawiadywania sprawami publicznymi, czyli w zarządzaniu publicznym. Dokonywały się one w znacznej mierze pod wpływem doświadczeń wyniesionych z sektora prywatnego. Racjonalność działań tego ostatniego stanowiła zawsze punkt odniesienia dla sektora publicznego. Zaczęto więc podejmować coraz śmielsze próby adaptacji rozwiązań z sektora prywatnego do sektora publicznego.

Szczególnie było to widoczne w przypadku modelu nowego zarządzania publicznego, wprowadzającego $\mathrm{w}$ szerokim zakresie elementy gry rynkowej do sektora publicznego. Potwierdziły to prowadzone przez autora i opisane w pracy badania bibliometryczne, wskazujące na rosnącą popularność wśród badaczy sektora publicznego problematyki rynku i konkurencji. Chociaż wdrażanie modelu nowego zarządzania publicznego przyniosło określony wzrost racjonalności tego sektora, to szybko okazało się, że kreowanie rozwiązań rynkowych nie zawsze zdaje egzamin w sektorze publicznym, że pewne wartości tego sektora są nie do pogodzenia z rynkiem.

Warto podkreślić, że w ostatnich latach nabiera znaczenia inny model zarządzania publicznego - model Public Governance, który bazuje na relacjach międzyorganizacyjnych, a szerzej - na sieciach współpracy. Potwierdzily to wspominane już badania bibliometryczne, wskazujące na rosnącą popularność tematów badawczych dotyczących sieci współpracy, relacji międzyorganizacyjnych czy innych form współdziałania. Model ten staje się czymś więcej niż metodą działań, staje się filozofią funkcjonowania organizacji publicznej.

Dokonane w rozdziale pierwszym porównanie systemów zarządzania w sektorze prywatnym oraz w sektorze publicznym wykazało, że oprócz 
niewątpliwych różnic istnieją między nimi także liczne podobieństwa. Sprawiły one, że wiele koncepcji charakterystycznych dla sektora prywatnego mogło być wykorzystanych w procesach usprawniania podmiotów użyteczności publicznej. Jedną z takich koncepcji jest marketing, rozumiany jako budowanie relacji z klientem i innymi interesariuszami. Jest on z powodzeniem wykorzystywany w takich obszarach tego sektora, jak budowanie polityki publicznej czy realizacja usług publicznych. Zdaniem autora potencjał koncepcji marketingu nadal nie został należycie wykorzystany w sektorze publicznym.

Praca została poświęcona marketingowi terytorialnemu w ujęciu relacyjnym. Z powodzeniem zrealizowano $\mathrm{w}$ niej sformułowany we wstępie cel główny pracy: próbę wyjaśnienia rozwoju koncepcji marketingu terytorialnego w oparciu o teorie wspótdziałania międzyorganizacyjnego. Autor zawęził spektrum prowadzonych rozważań do organizacji terytorialnej, rozumianej jako organizacyjny wymiar samorządu terytorialnego, czyli administracji terytorialnej wraz z jej kierownictwem. Dla budowy swojej pozycji konkurencyjnej OT musi odnaleźć się w sytuacji rynkowej i rywalizować z innymi terytoriami o mobilne czynniki wzrostu.

Jak wielokrotnie podkreślano w pracy, organizacje terytorialne cechuje pewna specyfika. Z jednej strony kreują one bowiem politykę lokalną czy regionalną, z drugiej zaś - realizują tę politykę i świadczą usługi publiczne. Tłem prowadzonych rozważań były procesy generowania konkurencyjności JST, a następnie, w węższym ujęciu, procesy pozyskiwania zasobów w postaci mobilnych czynników wzrostu, takich jak kapitał finansowy czy intelektualny. Te pożądane zasoby znajdują się w dyspozycji inwestorów, turystów i studentów, którzy mogą wyrazić gotowość realizacji swoich celów w danym regionie.

W pracy pozytywnie zweryfikowano główną hipotezę badawczą: koncepcja marketingu terytorialnego $w$ ujęciu relacyjnym rozumiana jako działania OT na rzecz pozyskiwania zewnętrznych użytkowników regionu (inwestorów, turystów, studentów), będących nośnikami mobilnych czynników rozwoju, opiera się na współdziałaniu międzyorganizacyjnym i opisujących je teoriach uwzględniających posiadane bądź kontrolowane przez zewnętrznych interesariuszy instytucjonalnych zasoby. Dokonująca się ewolucja zarządzania publicznego - od modelu biurokratycznego, poprzez model nowego zarządzania publicznego, do modelu Public Governance - przebiega $\mathrm{z}$ różnym natężeniem $\mathrm{w}$ poszczególnych krajach. W praktyce oznacza to, że wszędzie można znaleźć elementy wszystkich trzech wymienionych modeli, chociaż ich zakres jest zdecydowanie różny.

Badania pokazały, że w Polsce dominuje model nowego zarządzania publicznego, przy dużym udziale modelu biurokratycznego. Spotkać można oczywiście pewne elementy modelu Public Governance, ale 
w świadomości znacznej części menedżerów publicznych dominują dwa pozostałe modele. Oznacza to, że relacje w sektorze publicznym mają głównie charakter rynkowy, a ich otwarcie na relacje zewnętrzne jest nadal ograniczone. Jest ono zróżnicowane w poszczególnych badanych regionach. Otwarcie na relacje zewnętrzne jest wyższe w regionach o wyższym poziomie rozwoju. Na weryfikację tej hipotezy wskazuje $\mathrm{w}$ jakiś sposób badanie „tajemniczy klient”, z którego wynika, że w przypadku menedżerów publicznych mogą występować znaczne różnice pomiędzy deklarowanymi postawami kooperacyjnymi i rzeczywistymi ich działaniami.

W części teoretycznej zwracano uwagę, że dotychczasowe ujęcia marketingu terytorialnego nawiązują bezpośrednio do tradycyjnego marketingu w sektorze przedsiębiorstw. W marketingu tym dominuje jego charakter transakcyjny, zaś jego odniesienia teoretyczne opierają się głównie na teoriach wymiany rynkowej. Autor podziela tu pogląd innych badaczy, że podejście to nie przystaje do współczesnych potrzeb OT. Dzieje się tak ze względu na zachodzące zmiany uwarunkowań działalności organizacji publicznych, które następują wraz ze zmianami modelu zarządzania $\mathrm{w}$ tym sektorze. W nowych warunkach bardziej adekwatne do rzeczywistości okazują się teorie nawiązujące do relacji międzyorganizacyjnych czy teorii sieci. Jednocześnie obserwujemy deficyt badań pozwalających oprzeć marketing terytorialny na tych właśnie teoriach. Niniejsze opracowanie stanowi krok w tym właśnie kierunku.

W pracy dokonano charakterystyki rozwoju współczesnych koncepcji marketingu w sektorze przedsiębiorstw, bazujących na relacjach, rozszerzając tym samym przestrzeń dla wykorzystania marketingu w budowaniu konkurencyjności organizacji terytorialnej. W odróżnieniu od wcześniejszych koncepcji marketingowych, gdzie marketing w przedsiębiorstwie miał charakter funkcjonalny, marketing relacji zaczęto traktować jako rodzaj filozofii biznesowej firmy. Przy takim podejściu, nie tylko określone służby, lecz także każdy z pracowników tworzy ofertę dla klienta, który staje się jego partnerem $\mathrm{w}$ interesach. Ten rodzaj marketingu ma charakter zintegrowany, co oznacza szeroki zakres relacji utrzymywanych zarówno z klientami, jak i z innymi interesariuszami: dostawcami, pośrednikami, wpływowymi instytucjami, a nawet z potencjalnymi pracownikami. Podejście takie wymaga zmian $w$ organizacji, $w$ tym nie tylko zmian w jej strukturze, lecz przede wszystkim w sposobie myślenia pracowników.

W ramach marketingu relacji wykształcił się dodatkowo tzw. marketing interesariuszy, uwzględniający elementy partnerstwa międzyorganizacyjnego. Ta koncepcja wydaje się szczególnie odpowiednia dla specyfiki sektora publicznego. Dotyczy to zwłaszcza dużych i tym samym 
bardziej samodzielnych organizacji terytorialnych, którym powierza się zadania budowania przewagi konkurencyjnej terytorium wobec potencjalnych zewnętrznych jego użytkowników. W marketingu tym zmienił się sposób uzyskiwania przewagi konkurencyjnej. Jeśli dotychczas przewagę taką uzyskiwano na drodze aktywnej rywalizacji, to obecnie jest ona budowana poprzez wspominane współdziałanie z innymi organizacjami. Rośnie więc znaczenie relacji traktowanych jako zasób organizacji. W marketingu interesariuszy wszystkie zaangażowane strony uczestniczą w kreowaniu wartości u wszystkich partnerów.

Tak rozumiany marketing relacji okazał się atrakcyjny dla sektora publicznego. Stąd pojawiło się rosnące nim zainteresowanie zarówno od strony teoretycznej, jak i w zakresie podejmowanych działań w praktyce sektora publicznego. Studia literaturowe i rezultaty wcześniejszych badań wskazują jednoznacznie na przydatność tej koncepcji marketingu w sektorze publicznym, gdzie może być wykorzystywana w rozmaitych konfiguracjach.

Należy podkreślić, że odpowiednikiem zarządzania strategicznego $\mathrm{w}$ sektorze prywatnym jest polityka publiczna w sektorze publicznym. Nieprzypadkowo więc od pewnego czasu w obszarze tym podejmowane były próby wykorzystania marketingu w ujęciu relacyjnym, dla prowadzenia polityki rozwoju, zorientowanej na budowanie konkurencyjności terytorium. W obszarze tym autor umiejscowił również opisywane w monografii badania, mające na celu identyfikację głównych interesariuszy instytucjonalnych, publicznych i niepublicznych oraz dokonanie charakterystyki relacji, jakie organizacja terytorialna prowadzi z nimi na szczeblu regionu.

W badaniach tych opierano się na teorii interesariuszy, która okazała się przydatna w kontekście budowania przez region pozycji konkurencyjnej poprzez współdziałanie z interesariuszami instytucjonalnymi. Analizę prowadzono $\mathrm{z}$ uwzględnieniem rodzajów jednostek organizacyjnych badanych menedżerów publicznych z urzędów marszałkowskich, co pozwoliło na zaobserwowanie interesujących prawidłowości dotyczących budowania i prowadzenia relacji zewnętrznych z poszczególnymi typami interesariuszy. Jednostki organizacyjne nazwane w badaniu jako rynkowe (RYN) w praktyce realizowały zadania marketingowe. Porównano je z innymi rodzajami jednostek organizacyjnych (z sektorowymi - SEK i administracyjnymi - ADM) oraz wyciągnięto stosowne wnioski.

Badanie wykazało, że pośród wszystkich grup interesariuszy, z którymi region powinien współdziałać, to lokalne JST oraz uczelnie wyższe posiadają największy potencjał do współpracy oraz najszerszy zakres potencjalnych obszarów takiej współpracy. Badania te pozwoliły na skonstruowanie modelu sześciu rynków dla organizacji terytorialnej na 
szczeblu regionu, identyfikującego rynki kluczowych interesariuszy instytucjonalnych, od których zależy konkurencyjność regionu. Zatem odpowiednie współdziałanie z przedstawicielami tych rynków lub z ich kluczowymi uczestnikami uznać można za najlepszy sposób na podnoszenie konkurencyjności terytorium, skutkującej efektywną realizacją polityki rozwoju regionu.

Kolejny etap odnosił się już tylko do badania realizowanych przez region procesów marketingowych, dotyczących pozyskiwania mobilnych czynników wzrostu. Model sześciu rynków został uzupełniony o rynek dysponentów zasobów w postaci inwestorów, turystów i studentów, których umieszczono $\mathrm{w}$ centralnym jego punkcie. $\mathrm{W}$ prowadzonych badaniach przyjęto założenie, że MT w ujęciu relacyjnym to współdziałanie OT z jej interesariuszami instytucjonalnymi, podejmowane dla pozyskiwania zasobów z zewnątrz. Współdziałanie takie prowadzi w rezultacie do podnoszenia pozycji konkurencyjnej regionu.

W nawiązaniu do sformułowanej we wstępie głównej hipotezy badawczej można stwierdzić, że relacja region-miasto nie jest oparta głównie na zaufaniu i dążeniu do kreowania wzajemnych korzyści. Okazało się, że relacja ta ma bardziej rynkowy charakter i jest zdeterminowana dążeniem do ograniczania wpływu kontroli miasta nad zasobami. Region traktuje zatem współdziałanie jako sposób ograniczenia wpływu interesariusza na posiadane zasoby, które są ważne dla pozyskiwania inwestorów, turystów i studentów dla regionu. Działania takie z kolei przekładają się na wzrost konkurencyjności regionu.

Autor już na etapie badań w rozdziale piątym nieco szerzej eksplorował wątek relacji region-lokalne JST. W jego ocenie relacja region-stolica to kluczowa relacja dla budowania konkurencyjności regionu, dlatego zasługuje na bliższą analizę. Jak potwierdził jeden $\mathrm{z}$ respondentów $\mathrm{z}$ badanych urzędów marszałkowskich, region nie ma typowych instrumentów, które pozwalałyby mu prowadzić aktywna politykę wzmacniania konkurencyjności terytorium. Faktycznie samorząd regionu nie posiada w swojej dyspozycji podatków (regionalnych), nie może również udzielać ulg inwestycyjnych. W nieco lepszej sytuacji w tym zakresie jest np. miasto poprzez fakt, że to w jego dyspozycji jest podatek od nieruchomości, to ono kieruje szereg usług publicznych do inwestora, tworzy miejską przestrzeń, infrastrukturę lokalną, wykorzystywaną często przez turystów czy studentów. Zatem to miasto ma zasadniczy wpływ na tworzenie sprzyjających warunków dla inwestorów, turystów czy studentów. Jak zatem region może oddziaływać na te procesy w sytuacji braku zwierzchności nad miastem. Może to robić pośrednio, poprzez instrumenty polityki rozwoju, definiując zakres dofinansowywanych przedsięwzięć. Instrumenty takie muszą być jednak definiowane w sposób uniwersalny, stąd 
może się zdarzyć, że przyznane środki nie trafią do pożądanych przez region obszarów. W tej sytuacji znaczenia nabierają relacje nieformalne, zarówno na poziomie organizacyjnym, jak i na poziomie menedżerów relacji. Mają one charakter działań marketingowych.

Jako podstawę teoretyczną dla badania relacji region-miasto $\mathrm{w}$ procesie realizacji działań marketingowych przyjęto teorię zależności od zasobów. Przyjęto również, że metodą jej weryfikacji będzie zbiorowe studium przypadku. Dla takiej jej weryfikacji wytyczono przypadki skrajne w postaci par o relatywnie wysokim udziale zasobów stolicy w zasobach ogółem (łódzkie - Łódź, małopolskie - Kraków) oraz przypadki par o relatywnie niskim takim udziale (podkarpackie - Rzeszów, warmińsko-mazurskie - Olsztyn).

Rezultaty prowadzonych badań upoważniają autora do sformułowania rekomendacji co do kierunków dalszych badań w zakresie tej problematyki. Mogą one dotyczyć relacji regionu z kolejnymi grupami interesariuszy lub wybranymi liderami interesariuszy z poszczególnych rynków. Mogą to być również badania dotyczące przedsięwzięć współtworzonych przez trzech i więcej interesariuszy instytucjonalnych, celem bliższego poznania specyfiki istniejących między nimi relacji, a także określenia podstawy teoretycznej pozwalającej na ich interpretację.

Autor zdaje sobie sprawę z szeregu mankamentów zastosowanego podejścia badawczego. Często bowiem badania prowadzone metodą studium przypadku są narażone na krytykę z uwagi na względnie subiektywny dobór czynników czy ich wag dla obliczenia parametrów bądź mierników potencjału. Wykorzystana metoda wymaga niekiedy użycia intuicji badacza czy wnioskowania $z$ deficytem danych. Wydaje się jednak, że uzyskane rezultaty dają wymierny wkład w rozwój nauki, zwłaszcza w obszarze relacji międzyorganizacyjnych organizacji terytorialnej w kontekście prowadzonych przez nią procesów marketingowych. 


\section{Bibliografia}

Agranoff R., McGuire M. (2003), Collaborative Public Management. New Strategies for Local Governments, Georgetown University Press, Washington, D.C.

Alter C., Hage J. (1993), Organizations Working Together, Sage Publications, Newbury Park, CA.

Andersen S. K., Mailand M. (2002), The Role of Employers and Trade Unions in Multipartite Social Partnerships, The Copenhagen Center, Copenhagen.

Anders-Morawska J., Rudolf W. (2015), Orientacja rynkowa we wspótrządzeniu miastem, Wydawnictwo Uniwersytetu Łódzkiego, Łódź.

Anderson J. C., Hakansson H., Johanson J. (1994), Dyadic Business Relationships within a Business Network Context, "Journal of Marketing", vol. 58, no. 10.

Anderson P. (2008), Marketing, Strategic Planning and the Theory of the Firm, [w:] P. Maclaren, M. Saren, M. Tadajewski (eds.), Marketing Theory, Sage Library in Marketing, London.

Ashworth G. J., Kavaratzis M. (2008), Place Marketing: how did we get there and where are we going?, "Journal of Place Marketing and Development", vol. 1, no. 2.

Ashworth G. J., Voogd H. (1988), Marketing the City: Concepts, Processes and Dutch Application, "Town Planning Review", vol. 59, no. 1.

Ashworth G. J., Voogd H. (1990), Selling the City: Marketing Approaches in Public Sector Urban Planning, Belhaven Press, London.

Austin J. E. (2000), The Collaboration Challenge, Jossey-Bass, San Francisco.

Axelsson B., Easton G. (eds.), (1992), Industrial Networks: A New View of Reality, Routledge, London.

Baker F. P. (1995), Marketing in a local authority, "Journal of Marketing Practice: Applied Marketing Science”, vol. 1, issue 4.
Banachowicz B. (2007), Public governance - nowe podejście do zarządzania rozwojem lokalnym, [w:] D. Strahl (red.), Gospodarka lokalna i regionalna w teorii i praktyce, Prace Naukowe Akademii Ekonomicznej im. O. Langego we Wrocławiu, Wrocław.

Barcz J. (2008), Przewodnik po Traktacie z Lizbony, traktaty stanowiquce Unię Europejską: stan obecny oraz teksty skonsolidowane w brzmieniu Traktatu z Lizbony, LexisNexis, Warszawa.

Bąkowski A., Mażewska M. (2015), Ośrodki Innowacji i Przedsiębiorczości w Polsce, Stowarzyszenie Organizatorów Ośrodków Innowacji i Przedsiębiorczości w Polsce, Poznań-Warszawa.

Bean J., Hussey L. (1997, 2011), Marketing Public Sector Services, HB Publications, London.

Berglund E., Olsson K. (2010), Rethinking place marketing - a literature review, Proceedings for ERSA Congress (Sweden).

Berry L. (1983), Relationship Marketing, [w:] L. Berry, G. L. Shostack, G. D. Upah (eds.), Emerging Perspectives on Services Marketing, American Marketing Association, Chicago.

Berry L. (1995), Relationship Marketing of Services - Growing Internet, Emerging Perspectives, "Journal of the Academy of Marketing Science", vol. 23, no. 4.

Bevir M. (2007), Encyclopedia of Governance, SAGE Publications, London.

Bevir M. (2011), The SAGE Handbook of Governance, SAGE Publications Ltd., Berkeley.

Bhattacharya C. B. (2010), Introduction to the Special Section on Stakeholder Marketing, "Journal of Public Policy and Marketing", vol. 29 (1).

Bloom P. N., Dholaakia N. (1973), Marketer Behaviour and Public Policy: Some Unexplored Territory, "Journal of Marketing", vol. 37, October. 
Boerzel T., Pamuk J., Stahn A. (2008), Good Governance in the European Union, „Berliner Arbeitspapier zur Europaeischen Integration", no. 7.

Bourcher J. G. (1994), Urban Marketing: A Review, [w:] G. O. Braun (ed.), Managing and Marketing of Urban Development and Urban Life, Proceedings of the IGU-Commision on "Urban Development and Urban Life", 15-20 August, Berlin.

Bourne L. (2009), Stakeholder Relationship Management: A Maturity Model for Organisational Implementation, Gower, Farnham.

Brol R. (1998), Rozwój lokalny - nowa logika rozwoju gospodarczego, [w:] M. Obrębalski (red.), Gospodarka lokalna w teorii i praktyce, Wydawnictwo Akademii Ekonomicznej, Wrocław.

Bryson J. M. (2004), What to do When Stakeholders Matter. Stakeholder Identification and Analysis Techniques, "Public Management Review", vol. 6, no. 1.

Bryson J. M., Crosby B. C. (2008), Failing into Cross-Sector Collaboration Successfuly, [w:] L. Blomgren, R. O'Lear, M. E. Sharpe (eds.), Big Ideas in Collaborative Public Management, M. E. Sharpe, New York.

Brzeziński C. (2010), Metropolia i jej region, Wydawnictwo Uniwersytetu Łódzkiego, Łódź.

Burton S. (1999), Marketing for Public Organizations. New ways, new methods, "Public Management", vol. 1, issue 3.

Buurma H. (2001), Public policy marketing exchange in the public sector, "European Journal of Marketing", vol. 35, no. 11/12.

Chapman D., Cowdell T. (1998), New Public Sector Marketing, Prentice Hall, Upper Saddle River.

Cherryholmes C. H. (1992), Notes on Pragmatism and Scientific Realism, "Educational Researcher", August-September.

Christopher M., Payne A., Ballantyne D. (1991), Relationship Marketing: Bringing Quality, Customer Service and Marketing Together, Butterworth-Heinemann, Oxford.

Christopher M., Payne A., Ballantyne D. (1994), Relationship Marketing, Butterworth Heinemann, Oxford.
Christopher M., Payne A., Ballantyne D. (2008), Relationship Marketing. Creating Stakeholder Value, Elsevier, Oxford.

Cleveland H. (1973), The Future Executive. A guide for Tomorrow's Managers, Harper \& Row Publishers, New York, Hagerstown, San Francisco, London.

Cleveland H. (1985), The Knowledge Executive. Leadership in an Information Society, Truman Talley: E. P. Dutton, New York.

Coase R. (1937), The Nature of the Firm, "Economica", no. 4.

Commission of the European Communities (2001), European Governance a White Paper, Brussels 25.7.2001, COM 428 final, Dz. Urz.WE, C 287/1.

Cooper P. J., Brady L. P. (1998), Public Administration for the Twenty-First Century, Wadsworth Publishing Company, Belmont.

Coote L. (1994), Implementation of Relationship Marketing in an Accounting Practice, [w:] J. N. Sherth, A. Parvatiyar (eds.), Relationship Marketing: Theory, Methods and Applications, Conference Proceedings, Emory University, Center for Relational Marketing, Atlanta.

Creswell J. W. (2013), Projektowanie badań naukowych. Metody jakościowe, ilościowe i mieszane, Wydawnictwo Uniwersytetu Jagiellońskiego, Kraków.

Crotty M. (1998), The foundations of social research: Meaning and perspective in the research process, Sage, London.

Czakon W. (2013), Zastosowanie studiów przypadku w badaniach nauk o zarządzaniu, [w:] W. Czakon (red.), Podstawy metodologii badań w naukach o zarządzaniu, Oficyna a Wolters Kluwer business, Warszawa.

Czaputowicz J. (2005), Zarządzanie w administracji publicznej $w$ dobie globalizacji, „Służba Cywilna”, nr 11.

Czekan W. (2012), Sieci w zarządzaniu strategicznym, Oficyna a Wolters Kluwer business, Warszawa.

Czornik M. (2005), Promocja miasta, Wydawnictwo Uczelniane Akademii Ekonomicznej im. Karola Adamieckiego w Katowicach, Katowice.

Domański T. (red.), (1997), Marketing terytorialny. Strategiczne wyzwania dla miast i re- 
gionów, Centrum Badań i Studiów Francuskich, Uniwersytet Łódzki, Łódź.

Domański T. (red.), (2011), Marketing akademicki. Rola uniwersytetów $w$ promocji miast i regionów, Wydawnictwo Uniwersytetu Łódzkiego, Łódź.

Donaldson B., O'Toole T. (2002), Strategic Market Relationships: From Strategy to Implementation, John Wiley, Chichester.

Donaldson T., Preston L. E. (1995), The stakeholders theory of the Corporation - Concepts, evidence and implications, "Academy of Management Rewiew”, vol. 20.

Dowling J., Pfeffer J. (1975), Organizational Legitimacy, "Pacific Sociology Review", vol. 18 (January).

Doyle P. (1995), Marketing in the new millennium, "European Journal of Marketing", vol. 29, no. 12.

Drabek T. E., McEntire D. A. (2002), Emergent Phenomena and Multiorganizational Coordination in Disasters: Lessons from the Research Literature, "International Journal of Mass Emergencies and Disasters", vol. 20, no. 2.

Drucker P. F. (2000), Zarzq̨dzanie w XXI wieku, Wydawnictwo Muza, Warszawa.

Duczkowska-Piasecka M. (2013), Marketing terytorialny. Jak podejść do rozwoju z korzyścia dla wszystkich, Difin, Warszawa.

Dupuy F. (2002), Czemu tak trudno reformować administrację publiczną?, [w:] Rząd przyszłości, Urząd Służby Cywilnej, Warszawa.

Egan J. (2008), Relationship marketing. Exploring relational strategies in marketing, Prentice Hall - Financial Times, England.

Eisenhardt K. M. (1989), Building Theories from Case Study Research, "Academy of Management Review", vol. 14, no. 4.

Eisenhardt K. M., Graebner M. E. (2007), Theory Building from Cases: Opportunities and Challenges, "Academy of Management Journal", vol. 50, no. 1.

Eisinger P. (2000), The Politics of Bread and Circuses. Building the City for the visitor Class, "Urban Affairs Review", vol. 35, no. 3.

El-Ansary A. I., Kramer O. E. (1973), Social Marketing: The Family Planning Experience, "Journal of Marketing", vol. 37, July.
Elms H., Brammer S., Harris J. D., Phillips R. A. (2010), New Directions in Strategic Management and Business, "Ethics Quarterly", 20 (July).

Enderlein H., Wälti S., Zärn M. (eds.), (2010), Handbook of Multi-Level Governance, Edward Elgar Publishing, Cheltenham.

Ferlie E., Ashburner L., Fitzgerald L., Pettigrew A. (1996), The New Public Management in Action, Oxford University Press, Oxford.

Ferlie E., Hartley J., Martin S. (2003), Changing Public Service Organisations - Current Perspectives and Future Prospects, "British Journal of Management", no. 14.

Ferlie E., Lynn L. E. Jr., Pollitt C. (eds.), The Oxford Handbook of Public Management, Oxford University Press, Oxford.

Florek M. (2006, 2013), Podstawy marketingu terytorialnego, Akademia Ekonomiczna w Poznaniu, Poznań.

Florek M. (2014), Kapitał marki miasta zorientowany na konsumenta: źródła i pomiar, Wydawnictwo Uniwersytetu Ekonomicznego w Poznaniu, Poznań.

Florek M., Augustyn A. (2011), Strategia promocji jednostek samorzqdu terytorialnego zasady i procedury, BESTPLACE Europejski Instytut Marketingu Miejsc, Warszawa.

Florek M., Janiszewska K. (red.), (2008), Marketing terytorialny. Studia przypadków, Wydawnictwo Akademii Ekonomicznej w Poznaniu, Poznań.

Ford D. (ed.), (1990), Understanding Business Markets: Interaction, Relationships, Networks, Academic Press, London.

Frankowski Z. (2000), Marketing w zarządzaniu gmina, [w:] Działalność marketingowa gmin. Zarys ujęć marketingu terytorialnego, Seria: Region - Polityka - Promocja, Wyd. Wyższej Szkoły Humanistycznej, Ciechanów.

Frederickson H. G. (2005), Whatever Happened to Public Administration? Governance, Governance Everywhere, [w:] E. Ferlie, L. E. Lynn Jr., C. Pollitt (eds.), The Oxford Handbook of Public Management, Oxford University Press, Oxford.

Freeman R. E. (1984), Strategic ManagementA Stakeholder Approach, Stanford University Press, Stanford. 
Freeman E., Harrison J., Wicks A., Parmar B., Colle de S. (2010), Stakeholder Theory: the State of the Art, Cambridge University Press, Cambridge.

Fyall A., Garrod B. (2005), Tourism Marketing: A Collaborative Approach, Channel View Publications, New York.

Geddes M. (2008), Inter-organizational relationships in local and regional development partnerships, [w:] S. Cropper, M. Ebers, Ch. Huxham, P. S. Ring (eds.), The Oxford Handbook of Inter-organizational Relationships, Oxford University Press, Oxford, New York.

Geddes M., Bennington J. (2001), Social exclusion and partnership in the European Union, [w:] M. Geddes, J. Bennington (eds.), Local Partnership and Social Exclusion in the European Union: New Forms of Local Social Governance?, Routledge, London.

Glińska E. (2016), Budowanie marki miasta koncepcje, warunki, modele, Wolters Kluwer, Warszawa.

Gold R. J., Ward V. S. (eds.), (1994), Place Promotion. The Use of Publicity and Marketing to Sell Towns and Regions, Wiley \& Sons Ltd., Chichester.

Goldsmith S., Eggers W. D. (2004), Governing by Network: The New Shape of the Public Sector, Brooking Institution Press, Washington, D.C.

Górniak J., Wachnicki J. (2010), Pierwsze kroki w analizie danych: SPSS PL for Windows, Wydawnictwo SPSS Polska, Kraków.

Graham P. (1995), Are public sector organisations becoming customer centred?, "Marketing Intelligence and Planning", vol. 13, no. 1.

Gregor B. (2006), Ewolucja oraz współczesne koncepcje marketingu, [w:] T. Markowski (red.), Marketing terytorialny, Polska Akademia Nauk, Komitet Przestrzennego Zagospodarowania Kraju, Studia, t. CXVI, Warszawa.

Grönroos C. (1990), Marketing Redefined, "Management Decision", vol. 27, no. 1.

Grönroos L. (1996), Relationship marketing: strategic and tactical implications, "Management Decisions", vol. 34, no. 3.

Gummesson E. (2002), Total Relationship Marketing. Rethinking Marketing Management, Butterworth - Heinemann, Oxford.
Hakansson H. (1982), International Marketing and Purchasing of Industrial Goods, Wiley, Chichester.

Hall T. E., O'Toole L. J. (2004), Sharping Formal Network through the Regulatory Process, "Administration \& Society", vol. 36, no. 2.

Hatch M. J. (2002), Teoria organizacji, Wydawnictwo Naukowe PWN, Warszawa.

Hausner J. (2008), Zarządzanie publiczne. Podręcznik akademicki, Wydawnictwo Naukowe Scholar, Warszawa 2008.

Helden J. G. van (2000), Is Financial Stress an Incentive for the Adoption of Businesslike Planning and Control In Local Government? A Comparative study of Eight Dutch Municipalities, "Financial Accountability \& Management", vol. 16, no. 1

Hellwig Z. (1968), Zastosowanie metody taksonomicznej do typologicznego podziału krajów ze względu na poziom ich rozwoju oraz zasoby i strukturę wykwalifikowanych kadr, „Przegląd Statystyczny”, nr 4.

Hendberg B., Dahlgren G., Hasson J., Olve N.-G. (1994), Imaginära Organizationer (Imaginary Organizations), Liber-Hermonds, Malmö.

Hennart J.-F. (2008), Transaction Costs Perspectives on Inter-Organizational Relations, [w:] S. Cropper, M. Ebers, C. Huxham, P. Smith Ring (eds.), Oxford Handbook of Interorganizational Relations, Oxford University Press, Oxford.

Hereźniak M. (2011), Marka narodowa. Jak skutecznie budować wizerunek i reputację kraju, Polskie Wydawnictwo Ekonomiczne, Warszawa.

Heron J., Reason P. (1997), A Participatory Inquiry Paradigm, "Qualitative Inquiry", vol. 3.

Hood C. (1991), A Public Management for All Seasons, "Public Administration", vol. 69, no. 1.

Hunt H. K. (1997), CS/D: overview and future research direction, [w:] H. K. Hunt (ed.), Conceptualization and Measurement of $\mathrm{Cu}$ stomer Satisfaction and Dissatisfaction, MA: Marketing Science Institute, Cambridge.

Hunt S. D., Morgan R. M. (1994), Relationship Marketing in the Era of Network Competition, "Journal of Marketing Management", vol. 5 , no. 5 . 
Huxham, C. (1993), Pursuing collaborative advantage, "Journal of the Operational Research Society", vol. 44, no. 6.

Huxman C. (2000), The Challenge of Collaborative Government, "Public Management Review", vol. 2.

Izdebski H. (2007), Od administracji publicznej do public governance, „Zarządzanie Publiczne", $\mathrm{nr} 1$.

Jackson B. B. (1985), Winning and Keeping Industrial Customers: The Dynamics of Customer Relationships, D. C. Heath and Company, Lexington.

Jałowiecki B. (2010), Społeczne wytwarzanie przestrzeni, Wydawnictwo Naukowe Scholar, Warszawa.

Jarczewski W. (2007, 2012), Pozyskiwanie inwestorów do gmin, $\mathrm{ABC}$ a Wolters Kluwer business, Warszawa.

Jewtuchowicz A. (2001), Rozwój, środowisko, sieci innowacyjne i lokalne systemy produkcyjne, [w:] K. B. Matusiak, E. Stawasz, A. Jewtuchowicz (red.), Zewnętrzne determinanty rozwoju innowacyjnych firm, Wydawnictwo Uniwersytetu Łódzkiego, Łódź.

Jewtuchowicz A. (2013), Terytorium i współczesne dylematy jego rozwoju, Wydawnictwo Uniwersytetu Łódzkiego, Łódź.

Johnes H. Ch. G., Ennals R. (eds.), (2012), Creating Collaborative Advantage. Innovation and Knowledge Creation in Regional Economies, Gower, Farnham.

Kale P., Singh H., Perlmutter H. (2000), Learning and Protection of Proprietary Assets in Strategic Alliances, "Strategic Management Journal”, vol. 21, no. 3.

Kauf S. (2009), Orientacja marketingowa i logistyka w zarzadzaniu regionem, Uniwersytet Opolski, Studia i Monografie nr 418, Opole.

Kaźmierczak T., Hernik K. (red.), (2008), Społeczność lokalna w działaniu. Kapitał społeczny. Potencjat społeczny. Lokalne governance, Instytut Spraw Publicznych, Warszawa.

Klijn E. H. (2005), Networks and Inter-organizational Management: Challenging, Steering, Evaluation, and the Role of Public Actors in the Public Management, [w:] E. Ferlie, L. E. Lynn Jr., C. Pollitt (eds.), The Oxford Handbook of Public Management, Oxford University Press, Oxford.
Klijn E. H. (2008), Policy and implementation networks. Managing complex interactions, [w:] S. Cropper, M. Ebers, C. Huxham, P. Smith Ring (eds.), The Oxford Handbook of Inter-Organizational Relations, Oxford University Press, Oxford.

Knox S., Gruar C. (2007), The Application of Stakeholder Theory to Relationship Marketing Strategy Development In Non-profit Organization, "Journal of Business Etics", vol. 75.

Koliba Ch., Meek J. W., Zia A. (2011), Governance Networks in Public Administration and Public Policy, CRC Press. Taylor \& Francis Group, Boca Raton, London, New York.

Kopczewska K., Kopczewski T., Wójcik P. (2009), Metody ilościowe w R. Aplikacje ekonomiczne i finansowe, CeDeWu, Warszawa.

Korenik S. (2011), Region ekonomiczny w nowych realiach społeczno-gospodarczych, CeDeWu, Warszawa.

Koszałka J. (red.), (2010) Marketing, ujęcie terytorialne, Katedra Marketingu, Wydział Zarządzania i Ekonomii, Politechnika Gdańska, Gdańsk.

Kotler P. (1975), Marketing for Nonprofit Organizations, Prentice Hall, Englewood Cliffs.

Kotler P. (1992), Total marketing, Business Week Advance Executive Brief no. 2, McGrowth Hill, Columbus.

Kotler P., Haider D. H., Rein I. (1993), Marketing Places, Attracting Investment, Industry and Tourism to Cities, States and Nations, The Free Press, New York.

Kotler P., Hamlin M. A., Rein I., Haider D. H. (2002), Marketing Asian Places. Attracting Investment, Industry, and Tourism to Cities, States and Nations, John Wiley \& Sons (Asia) Pte Ltd, Singapore.

Kotler P., Zaltman G. (1971), Social marketing: an approach to planned social change, "Journal of Marketing", vol. 35, s. 3-13.

Kotler Ph., Asplund Ch., Rein I., Haider D. H. (1999), Marketing Places Europe. How to attract investments, industries, residents and visitors to cities, communities, regions and nations in Europe, Financial Times - Prentice Hall, London.

Kotler Ph., Kartajaya H., Setiawan I. (2010), Marketing 3.0. Dobry produkt? Zadowolony 
klient? Spełniony człowiek?, MT Biznes, Warszawa.

Kotler Ph., Keller K. L. (2012), Marketing, Dom Wydawniczy REBIS, Warszawa.

Kotler Ph., Levy S. (1969), Broadening the concept of marketing, "Journal of Marketing", vol. 33, January.

Kowalik I. (2011), Orientacja rynkowa w polskim samorządzie terytorialnym, Oficyna Wydawnicza Szkoły Głównej Handlowej, Warszawa.

Kożuch B. (2004), Zarządzanie publiczne w teorii i praktyce polskich organizacji, Placet, Warszawa.

Kożuch B. (2009), Wpływ współdziałania międzyorganizacyjnego na realizację celów organizacji publicznych, „Prace i Materiały Uniwersytetu Gdańskiego", t. 7, nr 2/1.

Laczniak G. R., Kennedy A.-M. (2011), Hyper Norms: Searching for a Global Code of Conduct, "Journal of Macromarketing", 31 (September).

Laczniak G. R., Murphy P. E. (2012), Stakeholder Theory and Marketing: Moving from a Firm-Centric to a Societal Perspective, "Journal of Public Policy \& Marketing”, vol. 31 (2).

Levitt T. (1983), After the Sale is Over, "Harvard Business Review", September.

Lipnack J., Stamps J. (1994), The Age of the Networks, Wiley, New York.

Lissowska M. (2008), Instytucje gospodarki rynkowej w Polsce. Institutions for Market Economy. The Case of Poland, Wydawnictwo C. H. Beck, Warszawa.

Lucarelli A., Berg P. O. (2011), City branding: a state-of-theart review of the research domain, "Journal of Place Management and Development", vol. 4, no. 1.

Łazarko K., Niedzielska A. (red.), (2011), Kreowanie wizerunku miejsca w koncepcji marketingu terytorialnego, Wydawnictwo Politechniki Częstochowskiej, Częstochowa.

Łogwiniuk K. (2011), Zastosowanie metod taksonomicznych w analizie porównawczej dostępu do infrastruktury ICT przez młodzież szkolna w Polsce, "Economy and Management", vol. 3, no. 1.

Markowski T. (1997a), Konkurencyjność i wspótpraca wewnatrzregionalna podstawa nowoczesnej polityki rozwoju regionalnego, [w:] Z. Mikołajewicz (red.), Podstawowe problemy polityki rozwoju regionalnego i lokalnego, Polskie Towarzystwo Ekonomiczne O/Opole, Opole.

Markowski T. (1997b), Miasto jako produkt wybrane aspekty marketingu miasta, [w:] T. Domański (red.), Marketing terytorialny strategiczne wyzwania dla miast $i$ regionów, Centrum Badań i Studiów Francuskich, Uniwersytet Łódzki, Łódź, s. 50-58.

Markowski T. (1999), Zarządzanie rozwojem miast, Wydawnictwo Naukowe PWN, Warszawa.

Marszał T., Markowski T. (1998), Konkurencyjność regionów jako element polityki przestrzennej, [w:] T. Marszał (red.), Wspótczesne problemy rozwoju regionalnego, KPZK PAN, Warszawa.

Markowski T. (red.), (2001), Marketing terytorialny, PAN Komitet Przestrzennego Zagospodarowania Kraju, Studia, t. CXII, Warszawa.

Maskell P. (1998), Low-tech competitive advantages and the role of proximity. The Danish wooden furniture industry, "European Urban and Regional Studies", no. 5.

McGuire M. (2006), Collaborative Public Management: Assessing What We Know and How We Know It, "Public Administration Review", December, Special Issue.

Medema S. G. (1996), Coase, Costs and Coordination, "Journal of Economic Issues", vol. 30 , no. 2 .

Meier K. J., Toole L. O. Jr. (2006), Bureaucracy in a Democratic state, The Johns Hopkins University Press, Baltimore.

Mick D. (2007), The End(s) of Marketing and the Neglect of Moral Responsibility, "Journal of Public Policy \& Marketing”, vol. 26 (Fall).

Millington S., Young C., Lever J. (1997), A bibliography of city marketing, "Journal of Local and Regional Studies”, vol. 17.

Ministerstwo Rozwoju Regionalnego (2008), Koncepcja good governance - refleksje do dyskusji, Warszawa, wrzesień.

Mintzberg H. (1979), Organizational Power and Goals: A Sceletal Theory in Strategic Management [w:] D. E. Schendel, Ch. Hofer (eds.), Strategic Management, Little Brown Company, Boston. 
Mitręga M. (2005), Marketing relacji. Teoria i praktyka, Wydawnictwo Fachowe CeDeWu, Warszawa.

Mitręga M. (2010), Zdolność sieciowa jako czynnik przewagi konkurencyjnej na rynku przedsiębiorstw, Wydawnictwo Akademii Ekonomicznej w Katowicach, Katowice.

Młodak A. (2006), Analiza taksonomiczna w statystyce regionalnej, Difin, Warszawa.

Möller K., Halinen A. (2000), Relationship Theory: Its Roots and Directions, "Journal of Marketing Management”, vol. 16.

Morawski W. (2012), Socjologia ekonomiczna: problemy, teorie, empiria, Wydawnictwo Naukowe PWN, Warszawa.

Morgan D. (2007), Paradigms lost and paradigms regained: Methodological implications of combining qualitative methodes, "Journal of Mixed Methods Research", vol. 1 , no. 1.

Morgan R., Hunt S. (1994), The Commitmenttrust Theory of Relationship Marketing, "Journal of Marketing", vol. 58.

Moullin M. (2002), Delivering Excellence in Health and Social Care, Open University Press, Buckingham.

Musialik R. (2011), Nowe zarządzanie publiczne i jego krytyka [w:] J. Wołejszo, A. Letkiewicz (red.), Public Management 2011: funkcjonowanie organizacji publicznych $w$ dynamicznym otoczeniu, t. I, Wyższa Szkoła Policji w Szczytnie, Szczytno.

Neuman W. L. (2000), Social Research Methods: Qualitative and Quantitative Approaches, Allyn \& Bacon, Boston.

Niestrój R. (red.), (2009), Wizerunek marketingu w Polsce, Wydawnictwo Uniwersytetu Ekonomicznego w Krakowie, Kraków.

Nowińska-Łaźniewska E. (2004), Relacje przestrzenne w Polsce $w$ okresie transformacji w świetle teorii rozwoju regionalnego, Wydawnictwo Akademii Ekonomicznej w Poznaniu, Poznań.

O'Leary R., Bingham L. B. (eds.) (2009), The Collaborative Public Manager. New Ideas for the Twenty-First Century, Georgetown University Press, Washington, D.C.

O'Leary R., Gazley B., McGurie M., Bingham L. B. (2009), Public Managers in Collaboration, [w:] R. O'Leary, L. B. Bingham (eds.), Collaborative Public Manager, Georgetown University Press, Washington D.C.

O'Toole L. J. (1997), Treating Networks Seriously: Practical and Research-Based Agendas in Public Administration, "Public Administration Review", vol. 57, no. 1.

O'Toole L. J. (2003), Intergovernmental Relations in Implementation, [w:] B. G. Peters, J. Pierre (eds.), Handbook of Public Administration, Sage, Thousand Oaks, CA.

Olejniczak K., Domaradzka A., Krzewski A., Ledzion B., Widła Ł. (2010), Polskie ministerstwa jako organizacje uczące się. Podsumowanie wyników dla czterech polskich ministerstw, Euroreg, Warszawa.

Olsson K., Berglund E. (2009), City Marketing: The Role of Citizen, [w:] T. Nyseth, A. Viken (eds.), Place Reinvention: Northern Perspectives, Ashgate, Farnham.

Opolski K., Modzelewski P. (2004), Zarządzanie jakościq w usługach publicznych, Wydawnictwo CeDeWu, Warszawa.

Osborne D., Gaebler T. (1992), Rządzić inaczej. Jak duch przedsiębiorczości przenika i przekształca administrację publiczną, Media Rodzina, Poznań.

Osborne S. P. (2010), Introduction. The (New) Public Governance: a suitable case for treatment?, [w:] S. P. Osborne (ed.), The New Public Governments? Emerging perspective on theory and practice of public governance, Routledge, London, New York.

Osborne S. P., McLaughlin K., Chew C. (2010), Relationship marketing, relational capital and governance of public services delivery, [w:] S. P. Osborne (ed.), The New Public Governance? Emerging perspectives on the theory and practice of public governance, Routledge Taylor \& Francis Group, London, New York.

Palmar B. L., Freeman R. E., Harrison J. S., Wick A. C., Purnell L., Cole de S. (2010), Stakeholder Theory: The State of the Art, "The Academy of Management Annals", vol. 4, no. 1, s. 403-445.

Payne A. (ed.), (1995), Advances in Relationship Marketing, Kogan Page, London.

Peters B. G. (2001), The Politics of Bureaucracy, Routledge, London, New York. 
Pfeffer J., Salancik G. R. (1978), The External Control of Organizations, Harper and Row, New York.

Philips R. (2003), Stakeholder Theory and Organizational Ethics, Berrett-Koehler, San Francisco.

Phillips D. C., Burbules N. C. (2000), Postpositivism and Educational Research, Rowman \& Littlefield, New York.

Pogorzelski J. (2012), Praktyczny marketing miast i regionów, Oficyna a Wolters Kluwer business, Warszawa.

Polonsky M. J. (1995), A Stakeholder theory approach to designing environmental marketing strategy, "Journal of Business and Industrial Marketing", vol. 10, no. 3.

Post J. E., Preston L. E., Sachs S. (2002), Redefining the Corporation: Stakeholder Management and Organizational Wealth, Stanford University Press, Stanford.

Proctor T. (2007), Public Sector Marketing, Prientice Hall - Financial Times, Harlow.

Proszkowska-Sala A., Florek M. (2010), Promocja miast. Nowa perspektywa, Ströer Polska, Warszawa.

Rainey H. G., Chun Y. H. (2005), Public and Private Management Compared, [w:] E. Hood, L. E. Lynn, Ch. Pollitt (eds.), The Oxford Handbook of Public Management, Oxford University Press, Oxford.

Rainisto S. K. (2003), Success Factors of Place Marketing: A Study of Place Marketing Practice in Northern Europe and the United States, Helsinki University of Technology, Espoo.

Raszkowski A. (2014), Place Marketing in the Process of Territorial Identity Creation and Strengthening, "Journal of European Economy", vol. 13, no. 2.

Reichheld F. F. (1996), The Loyalty Effect: The Hidden Force Behind Growth, Profits and Lasting Value, Harvard Business School Press, Boston, MA.

Roberts V., Russell H., Harding A., Parkinson M. (1995), Public-Private Voluntary Partnerships in Local Government, Local Government Management Board, London.

Rogoziński K. (2000), Marketing relacyjny według Gummessona, „Marketing i Rynek”, t. 12.
Rogut A. (2009), Governance - współczesne trendy zarządzania regionem, [w:] A. Rogut (red.), Wprowadzenie, Ocena dobrego wspótrządzenia, Wydawnictwo Społecznej Wyższej Szkoły Przedsiębiorczości i Zarządzania, Łódź.

Rudolf W. (2004a), Propozycje nowych instrumentów europejskiej polityki spójności na lata 2007-2013. Wnioski dla Polski, [w:] P. Bury (red.), Dylematy polskiej polityki społeczno-gospodarczej, Wydawnictwo Akademii Ekonomicznej im. Jana Kochanowskiego w Kielcach, Kielce.

Rudolf W. (2004b), Rola partnerstwa samorzadów w marketingu zewnętrznym regionu, [w:] J. Karwowski (red.), Partnerstwo w regionie, Polskie Towarzystwo Ekonomiczne, Szczecin.

Rudolf W. (2006a), Krajowe, czy regionalne programy operacyjne - dylematy programowania polityki spójności w Polsce na lata 2007-2013, [w:] L. Lewandowska (red.), Konkurencyjność firm regionu tódzkiego na rynkach międzynarodowych, Polskie Towarzystwo Ekonomiczne Oddział w Łodzi, Łódź.

Rudolf W. (2006b), Marketing partnerski w zarządzaniu regionem w warunkach Unii Europejskiej, [w:] E. Duliniec (red.), Ekspansja czy regres marketingu?, Polskie Wydawnictwo Ekonomiczne, Warszawa.

Rudolf W. (2006c), Zasada partnerstwa i jej praktyczne znaczenie w polityce regionalnej na przykładzie Polski, [w:] D. Strahl (red.), Gospodarka lokalna i regionalna $w$ teorii i praktyce, Prace Naukowe Akademii Ekonomicznej im. O. Langego we Wrocławiu, nr 1124, Wrocław.

Rudolf W. (2008a), Partnerstwo lokalne/regionalne jako forma praktycznej realizacji koncepcji governance w zarzadzaniu jednostka terytorialna, [w:] R. Brol (red.), Gospodarka lokalna w teorii i praktyce, Prace Naukowe Uniwersytetu Ekonomicznego we Wrocławiu, Nr 3 (1203), Wydawnictwo Uniwersytetu Ekonomicznego we Wrocławiu, Wrocław. Rudolf W. (2008b), Place Marketing as the Integrated Approach to Attract FDI. The Case of the City of Łódź, Poland, [w:] J. Sepp, D. Frear (eds.), Globalization and Institutional Deve- 
lopment, Congress of Political Economists International, USA.

Rudolf W. (2010a), Intensywność wspótpracy polskich województw z regionami partnerskimi w Niemczech i na Ukrainie, [w:] Znaczenie samorzadu terytorialnego dla rozwoju regionalnego w Polsce, Niemczech i na Ukrainie, Zeszyty Naukowe nr 620. Ekonomiczne Problemy Usług nr 61, Wydawnictwo Naukowe Uniwersytetu Szczecińskiego, Szczecin.

Rudolf W. (2010b), Partnerstwo podstawa marketingu regionu, [w:] S. Figiel (red.), Marketing w realiach współczesnego rynku. Strategie i działania marketingowe, Polskie Wydawnictwo Ekonomiczne, Warszawa.

Rudolf W., Karpińska M. (2005), Marketing terytorialny $w$ działalności samorzadu regionalnego, [w:] R. Brol (red.), Gospodarka lokalna i regionalna w teorii i praktyce, Prace Naukowe Akademii Ekonomicznej im. O. Langego we Wrocławiu, nr 1083, Wrocław.

Salamaga M. (2010), Mierniki podobieństwa grupowania obiektów, „Wiadomości Statystyczne", vol. 6, no. 589.

Samier E. (2005), Toward a Weberian Public Administration: The Infinite Web of History, Values, and Authority in Administrastive Mentalities, "Halduskultuur", no. 6.

Savitz A., Weber K. (2006), The Triple Bottom Line: How Today's Best-Run Companies are Achieving Economic, Social and Environmental Success and How You Can Too, Wiley, San Francisco.

Schmeider M., Scholz, J., Lubell, M., Mindruta, D., Edwardsen M. (2003), Building Consensual Institutions: Networks and the National Estuary Program, "American Journal of Political Science", vol. 47, no. 1.

Short J. R., Kim Y. H. (1999), Globalization and the City, Addison Wesley Longman, New York.

Smętkowski M., Gorzelak G., Jałowiecki B. (2009), Obszary metropolitarne w Polsce: problemy rozwojowe i delimitacja, „Raporty i Analizy EUROREG", nr 1.

Smith N. C., Palazzo G., Bhattacharya C. B. (2010), Marketing's Consequences: Stakeholder Marketing and Supply Chain Corporate Social Responsibility Issues, "Business Ethics Quarterly”, October, vol. 20, issue 4.
Stępowski R. (2015), Wszystko co chciatbyś wiedzieć o marketingu terytorialnym. Z praktyki polskich samorząów, Wydawnictwo Roster, Rawa Mazowiecka.

Stake R. (2000), Case Studies, [w:] N. Denzin, Y. Lincoln (eds.), Handbook of Qualitative Research, Sage, Thousand Oaks.

Stone C. (1989, 1993), Regime Politics, University Press of Kansas, Lawrence.

Suchecki B. (2010), Ekonometria przestrzenna, Wydawnictwo C. H. Beck, Warszawa.

Svendsen A. (1998), The Stakeholder Strategy: Profiting from Collaborative Business Relationship, Barrett-Koehler Publishers, San Francisco.

Svendsen A., Laberge M. (2006), A New Direction for CSR: Engaging Networks for Whole System Change, [w:] J. Jonker, M. de Witte (eds.), The Challenge of Organizing and Implementing Corporate Social Responsibility, Palgrave Macmillan, Basingstoke.

Szlachta J. (2011), Odniesienia europejskie nowej generacji programowania rozwoju regionalnego w Polsce, [w:] J. Szlachta, J. Woźniak (red.), Krajowa strategia rozwoju regionalnego do roku 2020 a strategie rozwoju społeczno-gospodarczego województw, Polska Akademia Nauk Komitet Przestrzennego Zagospodarowania Kraju, Studia, t. CXXXVII, Warszawa.

Szromnik A. (2004), Partnerstwo w koncepcji marketingu terytorialnego, [w]: J. Karwowski (red.), Lokalne układy partnerskie, PTE, Szczecin.

Szromnik A. (2007, 2008, 2010, 2012), Marketing terytorialny. Miasto i region na rynku, Oficyna Wolters Kluwer Business, Warszawa.

Szulce H., Florek M. (red.), (2005), Marketing terytorialny. Możliwości aplikacji, kierunki rozwoju, Wydawnictwo Akademii Ekonomicznej w Poznaniu, Poznań.

Urbanek P. (2005), Nadzór korporacyjny a wynagrodzenia menedżerów, Wydawnictwo Uniwersytetu Łódzkiego, Łódź.

Vargo S. L., Lusch R. F. (2004), Evolving to a New Dominant Logic for Marketing, "Journal of Marketing”, vol. 68 (January).

Verbeke A., Tung V. (2013), The Future of Stakeholder Management Theory: A Temporal 
Perspective, "Journal of Business Ethics", vol. 112, issue 3.

Ward S. V. (1998), The marketing and promotion of towns and cities 1850-2000, E\&FN SPON, London.

Webster F. E. Jr. (2005), A Perspective on the Evolution of Marketing Management, "Journal of Public Policy \& Marketing", vol. 24, no. 1.

Wilkie W. L., Gardner D. M. (1974), The Role o Marketing Research in Public Policy, "Journal od Marketing”, vol. 38, January.

Williamson O. E. (1993), Comparative Economic Organization. The Analysis of Discrete Structural Alternatives, [w:] S.-E. Sjostrand (ed.), Institutional Change. Theory and Empirical Findings, Sharpe, New York.

Williamson O. E. (1998), Ekonomiczne instytucje kapitalizmu. Firmy, rynki, relacje kontraktowe, Wydawnictwo Naukowe PWN, Warszawa.

Williamson O. E. (2005), Transaction Cost Economics, [w:] C. Ménard, M. M. Shirley (eds.), Handbook of New Institutional Economics, Springer, Dordrecht.

Wojciechowski E. (2007), Zarzadzanie w sektorze publicznym - od modelu tradycyjnego do governance, [w:] D. Strahl (red.), Gospodarka lokalna i regionalna $w$ teorii i praktyce, Prace Naukowe Akademii Ekonomicznej im. O. Langego we Wrocławiu, nr 1161, Wroctaw.

Wojtasiewicz L. (1996), Czynniki i bariery rozwoju lokalnego w aktualnej polityce gospodarczej Polski, [w:] M. Obrębalski (red.), Gospodarka lokalna $w$ teorii $i$ w praktyce, Wydawnictwo Akademii Ekonomicznej im. O. Langego we Wrocławiu, Wrocław.

Yin R. K. (2009), Case Study Research. Design and Methods. Forth Edition, Applied Social Reseach Methods Series vol. 5, Sage, Los Angeles, London, New Dehli, Singapore, Washington D.C.

Zalewski A. (2005), Reformy sektora publicznego $w$ duchu nowego zarzadzania publicznego, [w:] A. Zalewski (red.), Nowe zarządzanie publiczne w polskim samorządzie terytorialnym, Wydawnictwo SGH, Warszawa.
Zaltman G., Vertinsky I. (1971), Health Service Marketing: A Suggested Model, "Journal of Marketing", vol. 35, July.

Załęczna M. (2010), Instytucjonalne uwarunkowania rozwoju rynku nieruchomości w Polsce na tle doświadczeń państw zachodnich, Wydawnictwo Uniwersytetu Łódzkiego, Łódź.

Zawicki M. (2002), New Public Management i Public Governance - zarys koncepcji zarzqdzania publicznego, [w:] J. Hausner, M. Kukieła (red.), Studia z zakresu zarządzania publicznego, Wydawnictwo AE w Krakowie, Kraków.

Zimniewicz K. (2004), Aktualność klasyki zarzqdzania w świetle ustaleń H. Fayola, „Wspótczesne Zarządzanie", nr 1.

Zybała A. (2008), Rzeczpospolita partnerska. Czy w Polsce można zarzq̨dzać programami i politykami publicznymi w sposób partnerski?, Centrum Partnerstwa Społecznego „Dialog”, Warszawa.

Żabińska T. (2000), Wybrane modele strategii marketingowych, [w:] L. Żabińska (red.), Wybrane ujęcia paradygmatyczne i sektorowe, Wydawnictwo Akademii Ekonomicznej w Katowicach, Katowice. 


\section{Territorial marketing in the relational approach}

\section{(Summary)}

Processes of globalisation and regionalisation which take place in Europe and in the world have already resulted in the fact that cities and regions must seek external mobile resources - the territorial growth factors - in a more intensive way. Even a change in the paradigm of territorial development and basing it on the endogenic factors have not weakened the need of attracting the resources from the outside of the region (capital, labour force, knowledge, etc.). However, the values underlying the development of territorial advantage and techniques of efficient influence on potential external users, who own resources valuable for the development of the territory, have changed.

The study is focused on inter-organisational relations developed by the regions in the field of their marketing operations which are oriented towards the acquiring of mobile developmental resources from the markets of investors, tourists and students. The author also makes an attempt to find theoretical basis for the concept of relationship marketing, which has been adapted to a territorial organisation, in the field of its strategic operations referring to the development of its competitive advantage in the abovementioned markets.

Being implemented so far, the concept of territorial marketing (MT) has been based on transactional marketing, and it does not fit into more and more complex environment of territorial organisations (cities and regions). In accordance with the concept, the main task of territorial self-government units is to satisfy the needs of local communities and other users of particular territories. In author's opinion, however, the limited mobility of inhabitants results in the fact that seeing them as target customers is controversial, because such a situation cannot be considered as fully competitive. Average inhabitants do not have any real possibilities to change their place of living as soon as they feel dissatisfied with the way the local authorities and public managers work. Their mobility, 
which comes as a condition for applying the marketing concept in terms of territory, depends on economic, cultural, legal and administrative conditions. Even a great EU project from the beginning of the 1990s on the development of the Single European Market, with the free flow of labour force among the member states, did not start any revolution in that field.

During the recent decades, territorial marketing has gained some significant popularity resulting in a number of handbooks and monographs that can be observed on the European and Polish market. It should be noticed that contemporary literature in that field is mainly focused on the development of a place brand and on the efficient communication, in order to attract the interest of potential users in the particular territory. Despite the fact that there have been a number of publications which broadly define MT as the philosophy of city or region management, they have not been followed by any more detailed research in that field. Hence, there has appeared a research gap, especially in the field of seeing territorial marketing as a concept which refers to the strategic formation of the relations between a territory and its institutional stakeholders. This field has been already well described as far as the corporate sector is concerned (strategic management). One of the basic theories is the theory of stakeholders, which - despite the passing of time - is still developed, modified and applied to the description of new areas or phenomena. One of such areas can be the public sector, especially territorial self-governments, where it can be applied, mainly in the field of strategic marketing.

The dynamics of the contemporary environment of public organisations and some changes in the corporate market develop new conditions and pose new challenges to public organisations which often refer to the growth of their openness to inter-organisational relations. The author follows that path and seeks a possibility to describe the activities of territorial organisations, using the theories which are traditionally connected with the development of inter-organisational relations in the market environment.

The main aim of the presented study is an attempt to explain the development of a territorial marketing concept, based on the theories of inter-organisational cooperation. The study also aims at the identification of the main institutional stakeholders of a territorial organisation (OT) at the regional level and the characteristics of the relations among them. These aims have been achieved through theoretical analysis and extensive empirical research which have been carried out in several voivodships in Poland.

The dissertation also presents an attempt at the verification of the following main hypothesis: considering the relational approach, the concept of territorial marketing - understood as operations performed by a territo- 
rial organisation in order to attract external users of the region (investors, tourists, students) who hold and represent mobile developmental factors - is based on interorganisational cooperation and on theories which describe them, with the consideration of resources held or controlled by external institutional stakeholders.

In the following monograph, a pragmatic point of view has been assumed as a philosophical base for the mixed research applied here. It allows the author to base his research on various methods, various assumptions and numerous ways of collecting and analysing the data. In the study, the mixed research strategy of sequential character has been assumed. By the use of one method, it has allowed the author to organise and generalize the results which have been obtained with the use of other methods. Exploration research comes as a starting point; based on the obtained results, a decision is made to narrow the research field and to focus on the selected relations, selected cases and research units. The case study method applied in the research fits well into the assumed pragmatic approach, and numerous research techniques applied within that method allow us to learn more about the reality. The case study method has been also applied because of the fact that there are few public entities that can be treated as research subjects. While applying this method, there are no units selected for the research through the method of the statistical sample - the method applies the replication approach.

The study presents the MT concept which has been purposefully narrowed to the processes of attracting the mobile growth factors to a territory. It is necessary to replace a territorial self-government unit with a territorial organisation which consists of the regional administrative structures and their management. As opposed to a number of current approaches towards MT, inhabitants are identified neither with customers nor with users of the territory. They are seen as shareholders of the territory, who directly and indirectly affect regional management. Such influence is exercised by democratic institutions of power and processes of governance which enable inhabitants to become involved into the process of strategic decision-making that refers to the development of the region. Customers are external investors, tourists and students who are seen as holders of mobile resources of capital, labour and knowledge.

The monograph presents an attempt to apply the stakeholder marketing concept to develop the competitive edge of the territory, on the basis of the OT relations at the regional level, with its institutional stakeholders, that is namely: public and non-public entities. These problems are covered by the first part of the empirical research. This is exploration research which allows us to have a closer look at the role of cooperation in the context of the policy of regional development, with special 
consideration of activities performed by the organisational units of the regional office. The research provides the information on the elements of the environment of the regional authorities; it also indicates public and non-public entities (social and private) which are particularly significant for the cooperation which takes place during the implementation of the development policy at the regional level. The research allows us to define the character and potential of such cooperation. It also considers the basic role of public managers; in large territorial organisations their role is essential for the development of the relational potential of a territorial organisation.

On the basis of the obtained results of the research, the author formulates a model of six markets of institutional stakeholders for a territorial organisation at the regional level, in the context of pursuing the policy of development. He also refers to the classical theory of stakeholders. In the explorative part of the research, there have been four provinces (voivodships) selected, where some public managers from the analysed regional offices and the managers of institutional stakeholders in the region have acted as respondents.

In the second type of the research, there has been one relation selected out of six, which have been identified during the first type of the research (the region - local territorial units). The emphasis has been put on the relation between the region and the city (the capital city of the region), in terms of marketing processes run by the region, which are oriented toward the acquisition of investors, tourists and students. It should be noted that the capital city holds relatively the strongest position comparing to the region, among all the institutional stakeholders identified in the first part of the research. The observations here refer to two types of relations which are considered as two extreme cases. As far as the first one is concerned, the capital city owns relatively large resources, comparing them to the resources of the whole region, whereas in the second case the share of the capital city in regional resources is relatively small. The research refers to the resources which are of essential significance for the potential users of the region, that is namely: for investors, tourists and students. Finally, in the research there have been 4 pairs (region - city) identified, and their analysis has been applied for the verification of the hypothesis which refers to the resource dependence theory (RDT).

The research confirms the hypothesis stating that the theory describes the cooperation between the region and its capital city in terms of the processes during which some external growth factors are acquired by the region. Additionally, the research reveals the dominance of a NPM model in Poland, where a bureaucratic model still holds a great share. It is 
possible to observe some elements of a Public Governance model, however, two abovementioned models still dominate in public management. It means that relations in the public sector are mainly of market nature, and their openness towards external relations is still limited. It is indicated by the "mystery client" survey where some significant differences between the declared cooperation attitudes and actual operations can be observed.

Based on relationship marketing, stakeholder marketing has been additionally developed. It mainly considers the elements of inter-organisational partnership. That concept of marketing seems to be particularly suitable for the specific character of the public sector. It mainly refers to large and more independent territorial organisations which are entrusted with tasks referring to the development of territorial competitive advantage, considering the potential external users of particular territories. This type of marketing applies a different way of acquiring the competitive advantage. So far, such an advantage has been obtained through active competition, whereas at present it is developed through the cooperation with other organisations, as it has been previously mentioned. Hence, the significance of relations seen as organisational resources is continuously growing. In stakeholder marketing, all the involved parties participate in the development of values in all the partners.

The study is composed of six chapters. First three chapters are of theoretical nature, and they refer subsequently to: (1) the processes of management evolution in the public sector; (2) the problems of relationship marketing and (3) inter-organisational relations. The fourth chapter comes as a methodological part of the study, which refers to the empirical research. The results of the research are broadly described in the fifth and the sixth chapter. The fifth chapter is focused on relations considered in the context referring to the development of regional competitiveness. The sixth chapter is focused on one of the selected relations, which is analysed in the procedure of a collective case study.

The results of the research allow the author to formulate some recommendations for the direction of further research on the discussed problems. Such research can be focused on relations between the region and other groups of stakeholders or the selected stakeholders' leaders coming from the particular markets. The research may also refer to ventures co-developed by three and more institutional stakeholders. It would allow us to learn more on the specificity of current relations among them and to define a theoretical basis for their interpretation.

The author realises a number of shortcomings which result from the applied research approach. It often happens that the research carried out 
with the use of the case study method is exposed to criticism, considering a relatively subjective selection of factors and their weights for the calculation of parameters or the potential measures. Sometimes, the applied method of case study requires scholars to use their intuition and to conclude without sufficient data provided. It seems, however, that the obtained results come as rational contribution to the development of science, especially in the field of inter-organisational relations of territorial organisations, in the context of marketing processes. 


\section{Załączniki}

Załącznik 2.1. Trendy częstości występowania badanych terminów w słowach kluczowych artykułów naukowych w badanym zbiorze czasopism dotyczących sektora publicznego w latach 1995-2014

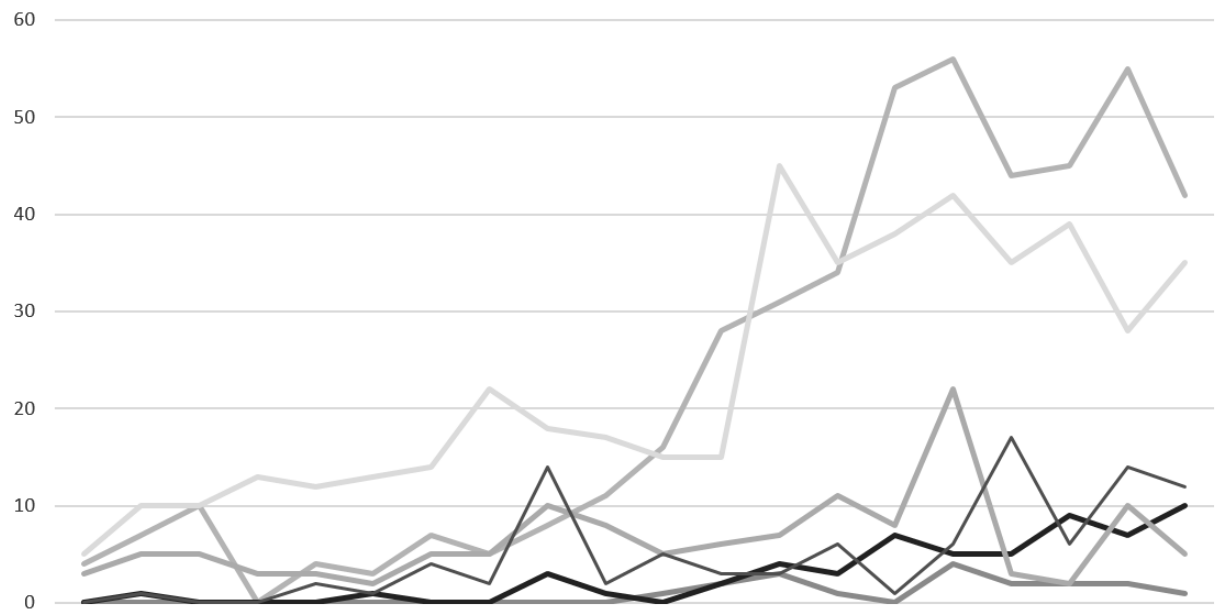

$199519961997199819992000200120022003200420052006200720082009201020112012 \quad 20132014$

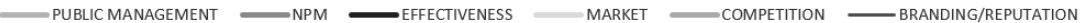

Źródło: opracowanie własne na podstawie bibliometrycznych baz danych: Journal Citation Report (Web of Science) oraz SCOPUS (ELSEVIER).

Załącznik 2.2. Częstość występowania terminów w słowach kluczowych artykułów badanego zbioru czasopism z zakresu sektora publicznego w czterech pięcioletnich okresach

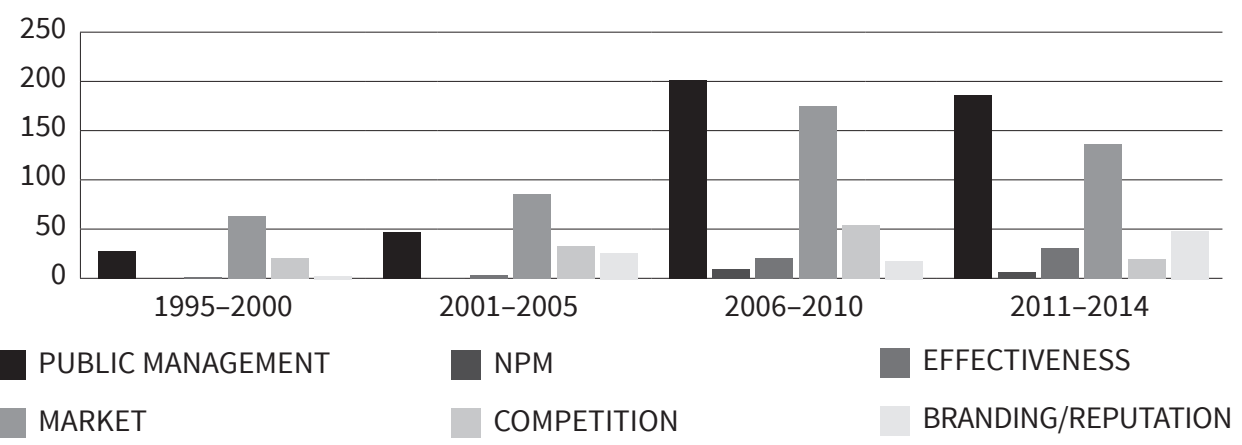

Źródło: opracowanie własne na podstawie bibliometrycznych baz danych: Journal Citation Report (Web of Science) oraz SCOPUS (ELSEVIER). 
Załącznik 3.1. Linie trendu występowania badanych terminów w słowach kluczowych artykutów naukowych w latach 1995-2014

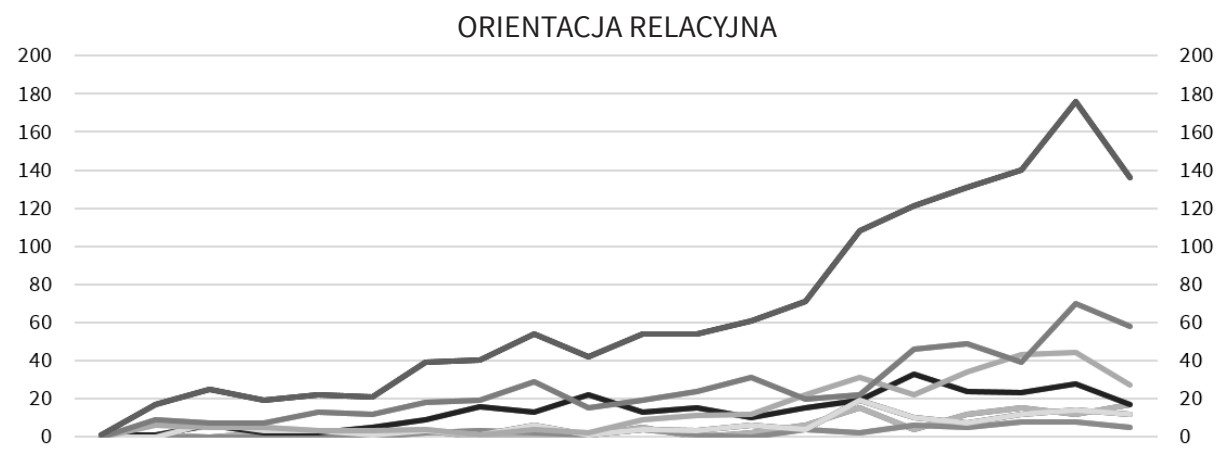

19951996199719981999200020012002200320042005200620072008200920102011201220132014

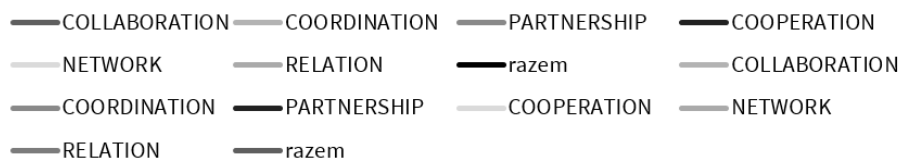

Źródło: opracowanie własne na podstawie bibliometrycznych baz danych: Journal Citation Report (Web of Science) oraz SCOPUS (ELSEVIER).

Załącznik 3.2. Częstość występowania badanych terminów w słowach kluczowych artykułów naukowych badanego zbioru czasopism z zakresu sektora publicznego w okresach pięcioletnich

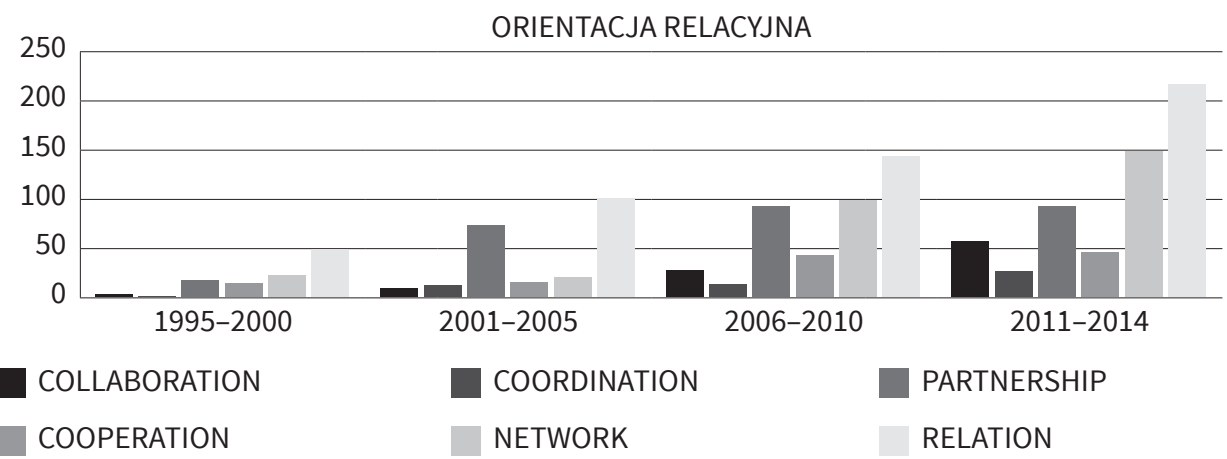

Źródło: opracowanie własne na podstawie bibliometrycznych baz danych: Journal Citation Report (Web of Science) oraz SCOPUS (ELSEVIER). 


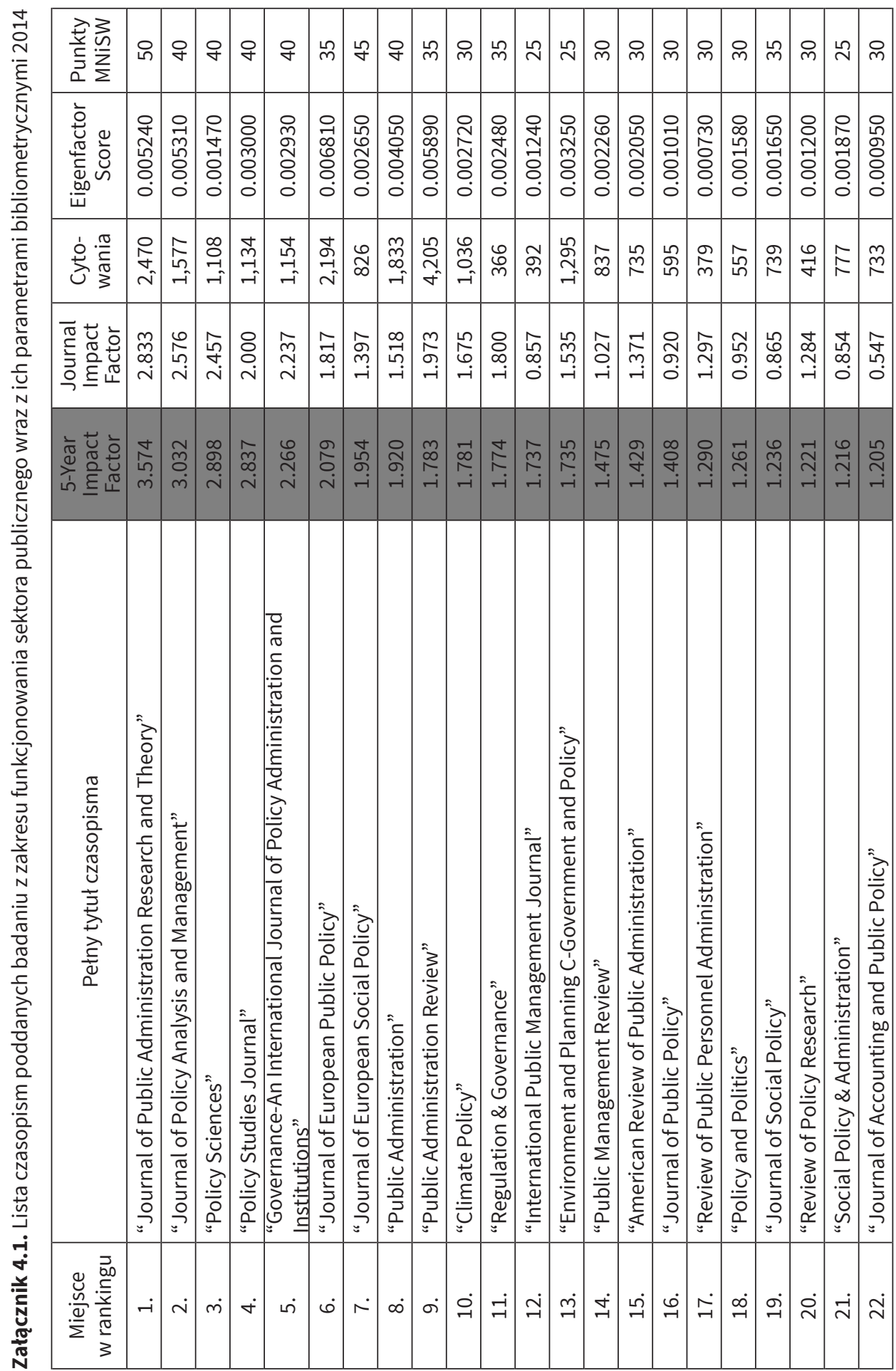




\begin{tabular}{|c|c|c|c|c|c|c|c|c|c|c|c|c|c|c|c|c|c|c|c|c|c|c|c|c|}
\hline 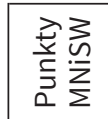 & $\stackrel{\llcorner}{\sim}$ & 이 & 이 & $\stackrel{\llcorner}{\sim}$ & $\stackrel{\llcorner}{\sim}$ & $\stackrel{\llcorner}{\rightarrow}$ & $\stackrel{\llcorner}{\sim}$ & $\stackrel{\llcorner}{\sim}$ & $\stackrel{\stackrel{2}{N}}{ }$ & $\stackrel{\stackrel{\sim}{N}}{\sim}$ & i & $\stackrel{\sim}{\sim}$ & ㅇ & $\stackrel{\sim}{\text { N }}$ & $\stackrel{2}{\sim}$ & ৩ & $\stackrel{\llcorner}{\sim}$ & $\stackrel{2}{\sim}$ & $\stackrel{\llcorner}{\sim}$ & $\stackrel{\text { I }}{\sim}$ & $\stackrel{\text { I }}{\sim}$ & $\stackrel{\llcorner}{\sim}$ & ㄱ & ㄱ \\
\hline 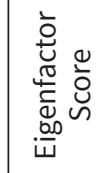 & 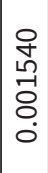 & 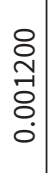 & 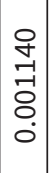 & $\begin{array}{l}0 \\
\dot{0} \\
m \\
-1 \\
8 \\
0\end{array}$ & 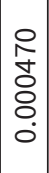 & 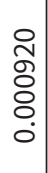 & 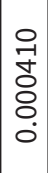 & \begin{tabular}{|l|}
0 \\
0 \\
0 \\
8 \\
8 \\
0 \\
0
\end{tabular} & 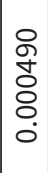 & $\begin{array}{l}8 \\
8 \\
0 \\
-1 \\
8 \\
0\end{array}$ & 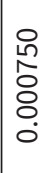 & \begin{tabular}{l} 
웅 \\
\multirow{2}{8}{} \\
8 \\
0 \\
0
\end{tabular} & 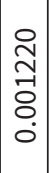 & $\begin{array}{l}\stackrel{0}{1} \\
\stackrel{1}{1} \\
\stackrel{8}{8} \\
\stackrel{0}{0}\end{array}$ & 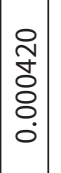 & \begin{tabular}{|l|} 
\\
우 \\
\multirow{2}{*}{} \\
8 \\
8 \\
0 \\
0
\end{tabular} & 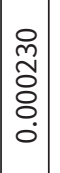 & 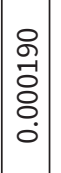 & 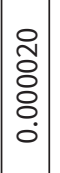 & $\left|\begin{array}{l|}0 \\
0 \\
0 \\
8 \\
0 \\
0 \\
0\end{array}\right|$ & \begin{tabular}{|l|}
0 \\
\\
0 \\
8 \\
8 \\
0 \\
0 \\
0
\end{tabular} & 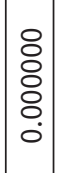 & $\begin{array}{l}\text { 요 } \\
8 \\
8 \\
\circ\end{array}$ & $\begin{array}{l}\text { O } \\
\text { O } \\
\text { Oे } \\
\text { O } \\
0\end{array}$ \\
\hline 定 $\frac{0}{\frac{\pi}{\pi}}$ & $\stackrel{\infty}{\stackrel{\infty}{f}}$ & $\begin{array}{l}\text { Õ } \\
\text { t }\end{array}$ & $\overrightarrow{\tilde{n}}$ & $\underset{m}{\sim}$ & 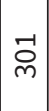 & $\stackrel{\infty}{\stackrel{\infty}{\sim}}$ & 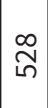 & $\stackrel{-1}{\infty}$ & 今 & $\begin{array}{l}m \\
0 \\
\llcorner\end{array}$ & ๙ & $\underset{\sim}{\stackrel{\sim}{\sim}}$ & $\stackrel{\sim}{\widehat{\sigma}}$ & $\hat{\infty}$ & $\stackrel{m}{\stackrel{m}{N}}$ & 守 & ஓ & ने & $\stackrel{\infty}{\sim}$ & $\stackrel{\varphi}{\sim}$ & $\vec{m}$ & m & 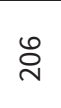 & $\underset{\infty}{\infty}$ \\
\hline 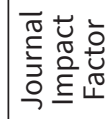 & ㄴon & \begin{tabular}{l}
\multirow{2}{*}{} \\
$\stackrel{0}{0}$
\end{tabular} & $\begin{array}{c}\tilde{1} \\
\sigma \\
0 \\
0\end{array}$ & $\begin{array}{l}\hat{\infty} \\
0 \\
0 \\
0\end{array}$ & 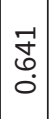 & $\begin{array}{l}\mathscr{\varphi} \\
\infty \\
+ \\
\vdots\end{array}$ & $\begin{array}{l}\text { స్ } \\
\text { กุ. }\end{array}$ & $\mid \begin{array}{c}\mathfrak{Z} \\
\mathfrak{G} \\
0 \\
0\end{array}$ & $\begin{array}{l}\text { ᄂn } \\
\text { นn } \\
0\end{array}$ & $\begin{array}{c}\hat{n} \\
\tilde{n} \\
0 \\
0\end{array}$ & 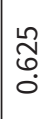 & $\begin{array}{l}0 \\
0 \\
+ \\
0 \\
0\end{array}$ & \begin{tabular}{|l|}
$\infty$ \\
\multirow{2}{*}{} \\
$\dot{0}$ \\
0
\end{tabular} & 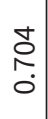 & $\begin{array}{l}\hat{n} \\
\tilde{m} \\
0 \\
0\end{array}$ & $\mid \begin{array}{l}0 \\
0 \\
+ \\
\dot{0}\end{array}$ & ஸू & $\begin{array}{c}m \\
m \\
m \\
0\end{array}$ & 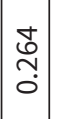 & \begin{tabular}{l|}
8 \\
0 \\
0 \\
0
\end{tabular} & $\begin{array}{c}\Delta \\
- \\
-1 \\
0\end{array}$ & $\mid$\begin{tabular}{l|}
$\infty$ \\
0 \\
0 \\
0 \\
0
\end{tabular} & 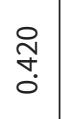 & స్ \\
\hline
\end{tabular}

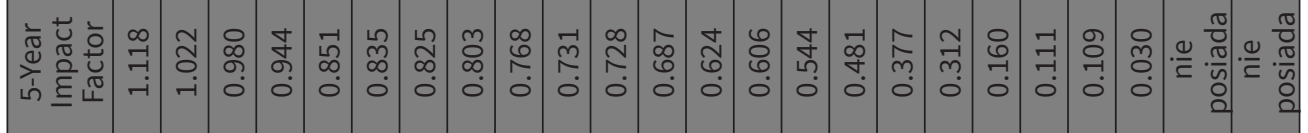

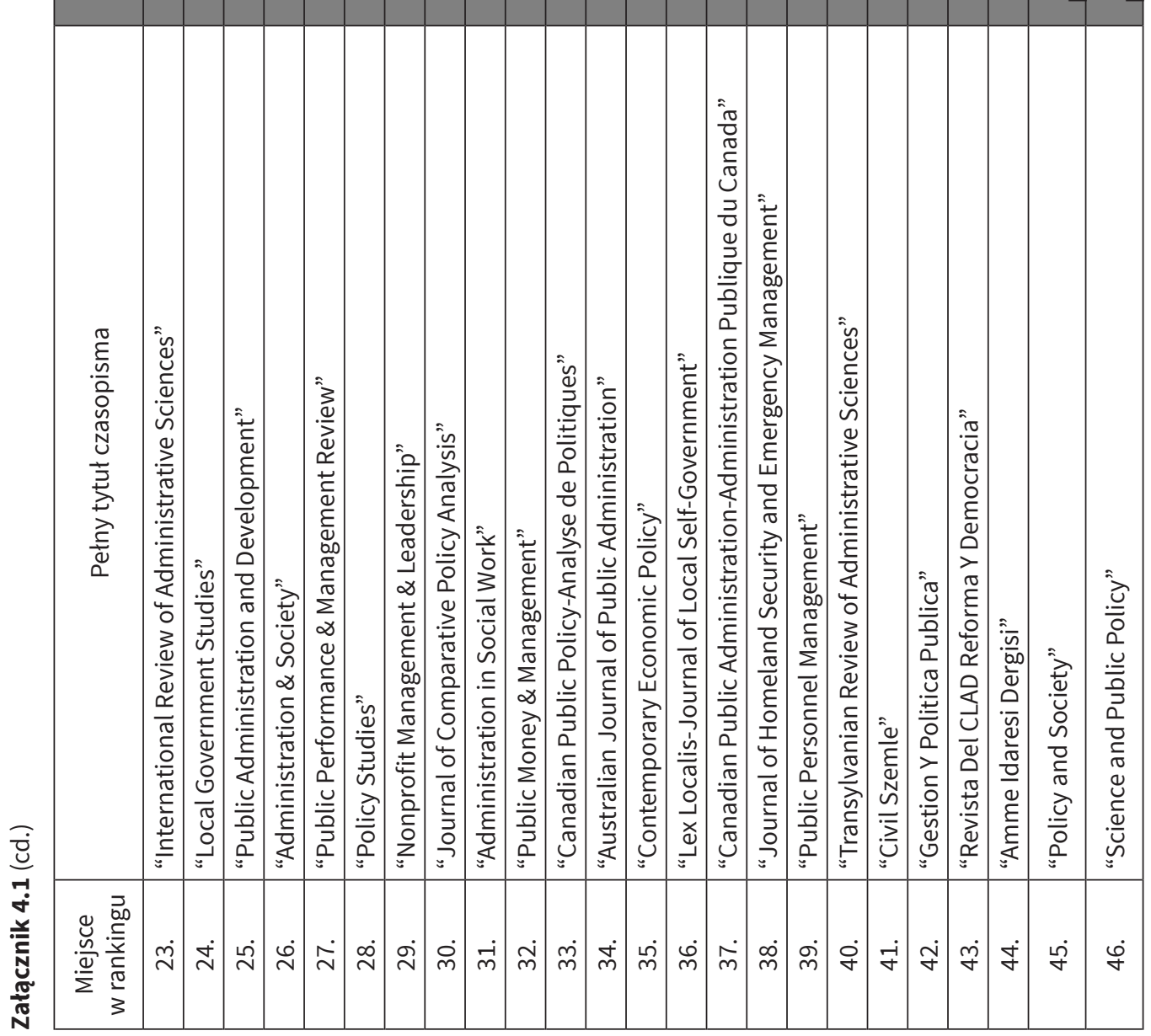


Załącznik 4.2. Opis procedury badania bibliometrycznego

Po wejściu do bazy Journal Citation Reports (JCR) wybrano: JCR Social Sciences Edition 2014 i polecenie: View a group of journals by Subject Category. Chcąc objąć badaniem czasopisma naukowe dotyczące sektora publicznego, wybrano jedną z kilkudziesięciu dostępnych - kategorię PUBLIC ADMINISTRATION. Wygenerowaną listę czasopism pogrupowano następnie według wielkości IP5, czyli wskaźnika wpływu czasopisma (Impact Factor) na dyskurs naukowy z ostatnich pięciu lat. Powstała w ten sposób lista 46 najbardziej cenionych czasopism na świecie w zakresie działalności sektora publicznego. Znalazły się na niej czasopisma publikujące teksty dotyczące administracji publicznej, zarządzania publicznego, polityki publicznej i innych tematów związanych z tą problematyką.

Następnie podjęto działania zmierzające do oszacowania popularności problemów badawczych z zakresu rynku i współpracy międzyorganizacyjnej w dyskursie naukowym, dotyczącym funkcjonowania sektora publicznego. Przyjęto, że miarą tych zjawisk będzie częstość występowania w słowach kluczowych świadomie wskazywanych przez autorów dwóch grup terminów: (1) związanych $\mathrm{z}$ rynkiem: public management, NPM, effectiveness, market, competition, branding, reputation oraz (2) związanych z relacjami: cooperation, collaboration, partnership, coordination, network, relations, branding.

Ze względu na fakt, że w bazie Web of Science nie ma możliwości wyszukiwania artykułów według słów kluczowych, zdecydowano się skorzystać w procesie badawczym $z$ zasobów bazy SCOPUS według następującej procedury. W bazie SCOPUS wybierano: document search, gdzie wpisywano pełne nazwy kolejnych czasopism z listy, np. JOURNAL OF PEASANT STUDIES. Korzystano wtedy z możliwości poszukiwania według dwóch kryteriów - wspomnianego tytułu czasopisma: „Source Title” oraz słowa kluczowego: „Keywords”, gdzie kolejno wpisywano każdy z wytypowanych terminów.

Przed naciśnięciem klawisza: Search zaznaczono przedział czasowy: 19952014 oraz: artykuły naukowe (Article). Po wygenerowaniu listy artykułów z kolejnych czasopism poszukiwano na ekranie zakładki: "Analyze search results", a po jej naciśnięciu otrzymano wyniki.

$\mathrm{W}$ procesie badawczym przyjęto następującą procedurę: wybierano czasopismo (według pozycji na liście) i uzupełniano dane dla poszczególnych lat, dla kolejnych poszukiwanych terminów (łącznie X terminów dla orientacji rynkowej i Y terminów dla orientacji relacyjnej). W procesie badawczym wygenerowano 598 takich list (7 terminów rynkowych x 46 tytułów czasopism +6 terminów relacyjnych x 46 tytułów czasopism). W części przypadków listy nie zawierały żadnych artykułów, w innych po kilka czy kilkanaście artykułów, w których w słowach kluczowych pojawiły się poszukiwane terminy. 


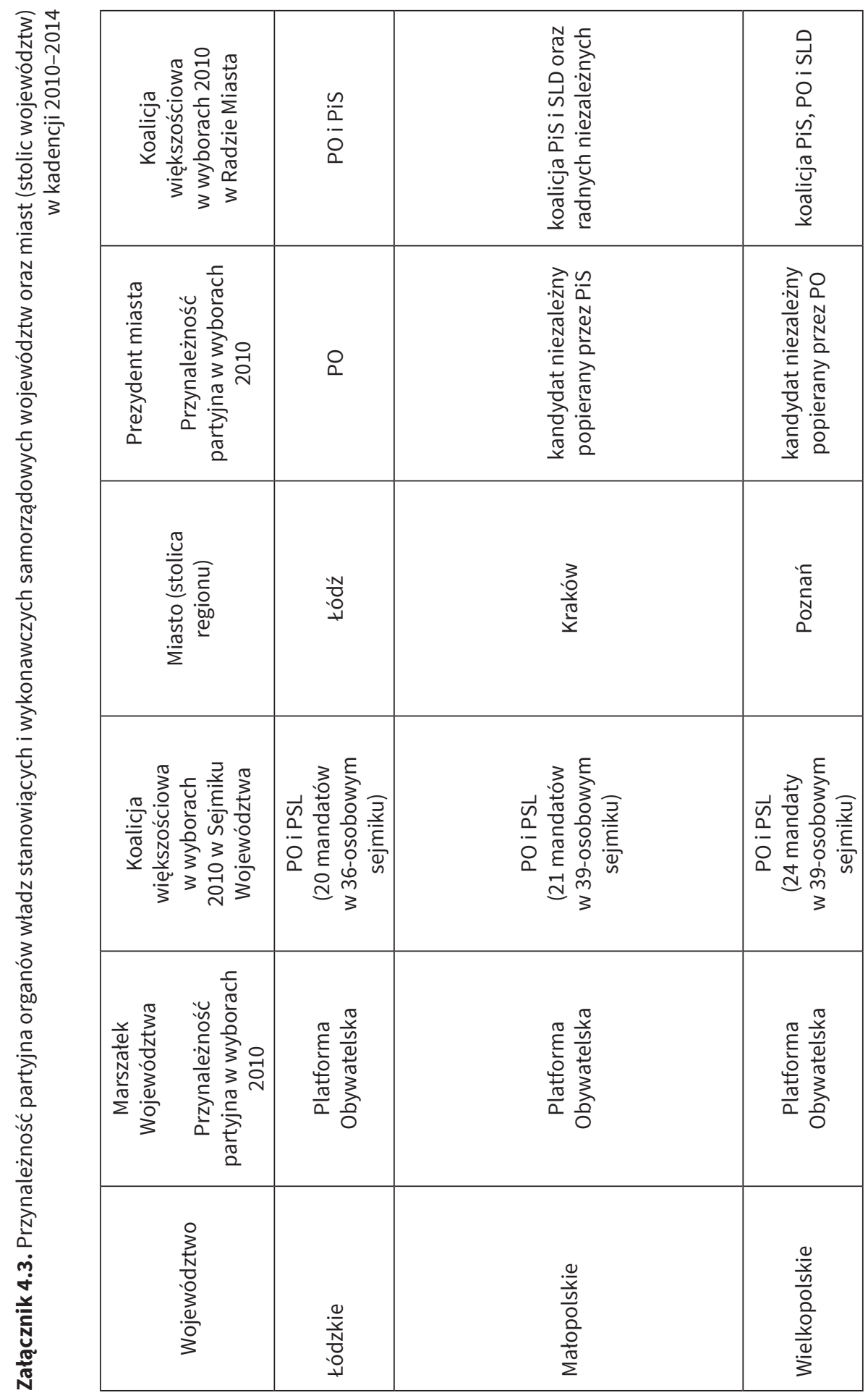




\begin{tabular}{|c|c|c|c|c|}
\hline$\frac{n}{\frac{n}{\alpha}}$ & 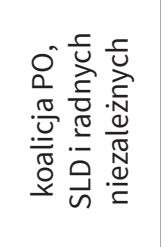 & 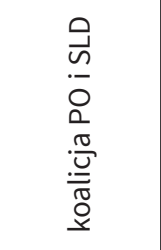 & 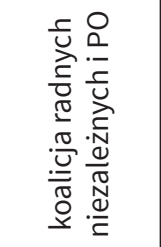 & 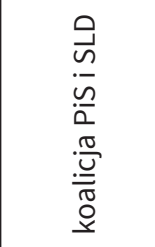 \\
\hline ○ & 光 & 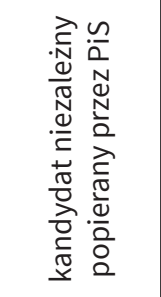 & 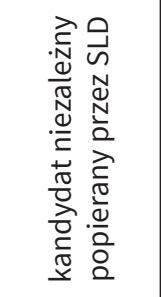 & 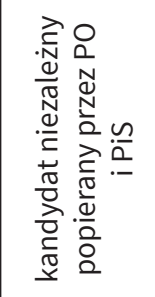 \\
\hline$\frac{. \sqsubseteq}{3}$ & 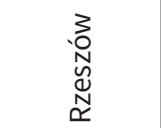 & 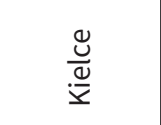 & 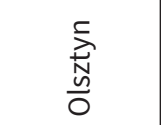 & 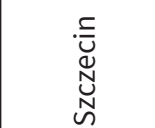 \\
\hline 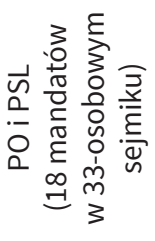 & 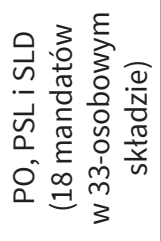 & 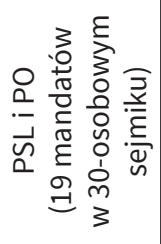 & 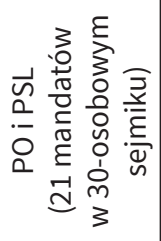 & 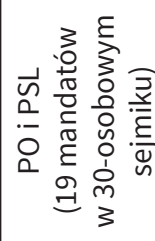 \\
\hline 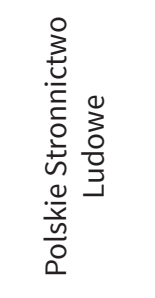 & 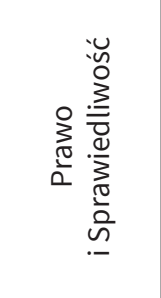 & 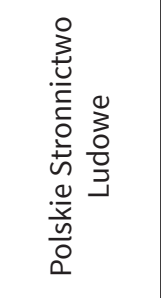 & 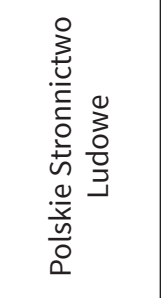 & 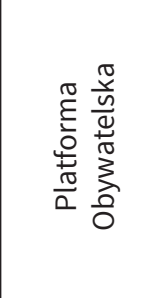 \\
\hline $\begin{array}{l}\frac{0}{\frac{0}{v}} \\
\frac{0}{2} \\
\frac{0}{3}\end{array}$ & $\begin{array}{l}\frac{0}{0} \\
\frac{0}{0} \\
\frac{0}{0} \\
\frac{0}{0} \\
\frac{0}{0} \\
\frac{0}{0}\end{array}$ & 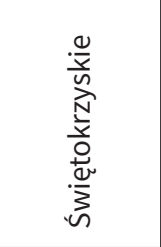 & 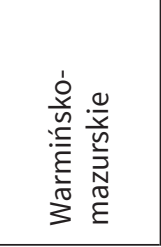 & 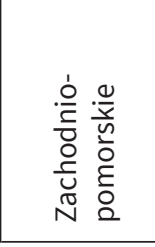 \\
\hline
\end{tabular}


Załącznik 5.1. Kwestionariusz wywiadu z menedżerami publicznymi badanych OT. Postawa samorządu regionu wobec współdziałania (czyli nawiązywania partnerskich relacji z podmiotami w regionie)

ANKIETER: dziękuję, że zgodził się Pan/Pani na spotkanie i rozmowę na temat współpracy urzędu marszałkowskiego z podmiotami zewnętrznymi przy realizacji polityki rozwoju. Do badania zostały wybrane te departamenty, które maja bezpośredni wpływ na realizowana $w$ województwie wielkopolskim politykę rozwoju.

Wywiad składa się z 3 czesści. Pierwsza $z$ nich dotyczy problematyki wspótpracy poszczególnych departamentów wewnątrz urzędu. W części drugiej chcielibyśmy poznać Pana/Pani opinie dotyczace współdziałania Pana/Pani departamentu z instytucjami publicznymi, w tym zwłaszcza $w$ relacji samorzad regionu-samorzady lokalne. Ostatnia czesść wywiadu jest poświęcona zagadnieniu współdziałania departamentu z instytucjami niepublicznymi (społecznymi i prywatnymi).

1. Czy uważa Pan/Pani Urząd Marszałkowski Województwa Wielkopolskiego za instytucję otwartą na wspólne przedsięwzięcia, projekty, działania, realizowane z zewnętrznymi podmiotami na rzecz społeczności regionu?

2. Jaka jest rola takiej współpracy dla Pana/Pani departamentu?

3. Jak Pan/Pani ocenia współpracę pomiędzy departamentami wewnątrz Urzędu Marszałkowskiego (zakres, formy współpracy, częstotliwość kontaktów)? Jakie zmiany należałoby wprowadzić, aby usprawnić pozytywną współpracę departamentów?

Na potrzeby niniejszego badania chcielibyśmy przyjąć, że partnerstwo to względnie trwaty, dtugookresowy zwiąek między podmiotami, oparty na wymianie informacji i wzajemnym zaufaniu oraz na dzieleniu się wspólnymi korzyściami, a także ewentualnym ryzykiem. Związki partnerskie moga dotyczyć zarówno spraw strategicznych, jak i pojedynczych projektów. 
4. Proszę ustosunkować się do kilku poniższych stwierdzeń, które dotyczą tak rozumianego partnerstwa. Dla każdego należy wybrać tylko jedną z odpowiedzi (całkowicie się zgadzam, zgadzam się, trudno powiedzieć, nie zgadzam się, całkowicie się nie zgadzam).

ANKIETER: wręczamy respondentowi kartę $\mathrm{A} z$ definicją partnerstwa oraz lista stwierdzeń.

\begin{tabular}{|c|c|c|c|c|c|c|}
\hline & & $\begin{array}{l}\text { Całko- } \\
\text { wicie się } \\
\text { zgadzam }\end{array}$ & $\begin{array}{l}\text { Zgadzam } \\
\text { się }\end{array}$ & $\begin{array}{l}\text { Trudno } \\
\text { powie- } \\
\text { dzieć }\end{array}$ & $\begin{array}{l}\text { Nie zga- } \\
\text { dzam się }\end{array}$ & $\begin{array}{l}\text { Catkowi- } \\
\text { cie się } \\
\text { nie zga- } \\
\text { dzam }\end{array}$ \\
\hline 1. & $\begin{array}{l}\text { Wspólne działania } \\
\text { przynoszą lepsze efekty }\end{array}$ & & & & & \\
\hline 2. & $\begin{array}{l}\text { Partnerstwo z innymi } \\
\text { podmiotami to } \\
\text { zagrożenie dla Urzędu } \\
\text { Marszałkowskiego }\end{array}$ & & & & & \\
\hline 3. & $\begin{array}{l}\text { Partnerstwo to tylko } \\
\text { teoria, w praktyce jest to } \\
\text { niemożliwe }\end{array}$ & & & & & \\
\hline 4. & $\begin{array}{l}\text { Partnerstwo } \\
\text { w działalności Urzędu } \\
\text { Marszałkowskiego } \\
\text { jest całkowicie } \\
\text { zdeterminowane przez } \\
\text { przepisy funduszy } \\
\text { unijnych }\end{array}$ & & & & & \\
\hline 5. & $\begin{array}{l}\text { Partnerstwo to dopiero } \\
\text { przyszłość, bo wymaga } \\
\text { ogromnej świadomości } \\
\text { obu stron }\end{array}$ & & & & & \\
\hline 6. & $\begin{array}{l}\text { Partnerstwo to warunek } \\
\text { decydujący o pozycji } \\
\text { regionu w przyszłości }\end{array}$ & & & & & \\
\hline
\end{tabular}

Kolejne pytanie dotyczy wszystkich instytucji zewnętrznych (publicznych i niepublicznych) - potencjalnych partnerów samorządu regionu.

5. Proszę wskazać 3 najważniejsze czynniki, które skłaniają Departament do nawiązywania partnerskich relacji z potencjalnymi partnerami?

ANKIETER: wręczamy badanemu kartę B $z$ odpowiedziami, a następnie wpisujemy obok poniższych stwierdzeń odpowiedź wskazana jako 1, 2 i 3. 


\begin{tabular}{|c|}
\hline Czynniki \\
\hline $\begin{array}{l}\text { Presja podmiotów publicznych z regionu chcących współdziałać (potencjalni partnerzy } \\
\text { sami zabiegają u dyrekcji departamentu o wspólne przedsięwzięcia). }\end{array}$ \\
\hline $\begin{array}{l}\text { Presja na departament ze strony członków zarządu województwa, aby nawiązywać } \\
\text { szersze kontakty z potencjalnymi partnerami }\end{array}$ \\
\hline $\begin{array}{l}\text { Obowiązek współdziałania wynikający z przepisów krajowych (ustawa o samorządzie } \\
\text { województwa, art. 12.1). }\end{array}$ \\
\hline Zasada partnerstwa wynikająca z przepisów europejskich (Rozporządzenie 1083/06) \\
\hline Chęć pozyskania zewnętrznych środków \\
\hline Większe możliwości realizacji postawionych przed samorządem zadań \\
\hline Chęć skorzystania z doświadczenia, wiedzy, kompetencji innych podmiotów \\
\hline Czynnik lokalnej polityki (współpracując z innymi, zyskujemy wyborców) \\
\hline Pewna moda na „współdziałanie” wynikająca z ogólnego stylu działań JST \\
\hline Inne czynniki, jakie? (proszę wpisać) \\
\hline \\
\hline
\end{tabular}

6. Proszę wskazać 3 najważniejsze czynniki, które utrudniają Pana/Pani Departamentowi nawiązywanie partnerskich relacji z potencjalnymi partnerami?

ANKIETER: wręczamy badanemu kartę $C$ z odpowiedziami, a następnie wpisujemy obok poniższych stwierdzeń odpowiedź wskazana jako 1, 2 i 3. Pytanie dotyczy relacji ze wszystkimi partnerami (publicznymi i niepublicznymi).

\begin{tabular}{|c|}
\hline Czynniki \\
\hline Brak chęci współpracy po stronie departamentu \\
\hline $\begin{array}{l}\text { Nieprzygotowanie pracowników departamentu do nawiązywania i prowadzenia } \\
\text { zewnętrznej współpracy }\end{array}$ \\
\hline $\begin{array}{l}\text { Brak „zielonego światła” ze strony zarządu województwa do nawiązywania } \\
\text { i prowadzenia współpracy z podmiotami zewnętrznymi }\end{array}$ \\
\hline $\begin{array}{l}\text { Presja czynników politycznych (osoby reprezentujące organizację - potencjalnego } \\
\text { partnera mają odmienne przekonania polityczne niż opcja reprezentowana przez } \\
\text { samorząd regionu) }\end{array}$ \\
\hline Ograniczenia kompetencyjne po stronie Urzędu Marszałkowskiego \\
\hline Przepisy prawne ograniczające współpracę (np. przepisy podatkowe) \\
\hline Nieczytelne reguły współpracy \\
\hline Niechęć potencjalnych partnerów do podejmowania współpracy z departamentem \\
\hline Roszczeniowe podejście partnerów \\
\hline Cechy osobowościowe osób reprezentujących partnerów \\
\hline Inne czynniki - jakie? (proszę wpisać) \\
\hline
\end{tabular}




\section{WSPÓtPRACA SAMORZĄDU REGIONU Z PODMIOTAMI PUBLICZNYMI}

A teraz przejdziemy do opisu relacji Pana/Pani departamentu z podmiotami publicznymi. W badaniu przyjęliśmy, że potencjalnymi partnerami departamentu do stronie podmiotów publicznych będa takie instytucje jak: samorządy lokalne, wojewoda i centralna administracja państwowa, urzędy marszałkowskie innych województw, publiczne instytucje nauki i badań oraz regiony partnerskie i organizacje międzynarodowe zrzeszajace regiony.

7. Proszę wskazać, z którymi z poniższych podmiotów publicznych Pana/Pani Departament współpracuje przy realizacji powierzonych mu zadań. Tam, gdzie jest to możliwe, proszę doprecyzować, podając nazwy podmiotów.

ANKIETER: wręczamy badanemu kartę $\mathbf{D}$ z odpowiedziami.

\begin{tabular}{|c|c|c|}
\hline $\begin{array}{l}\text { Podmioty } \\
\text { publiczne }\end{array}$ & Odpowiedzi & Rodzaje podmiotów (nazwy) \\
\hline \multirow{2}{*}{$\begin{array}{l}\text { JST z obszaru } \\
\text { województwa } \\
\text { i ich związki }\end{array}$} & TAK & \\
\hline & NIE & \\
\hline \multirow{2}{*}{$\begin{array}{l}\text { Wojewoda i jego } \\
\text { służby }\end{array}$} & TAK & \\
\hline & NIE & \\
\hline \multirow{2}{*}{$\begin{array}{l}\text { Administracja } \\
\text { rządowa } \\
\text { (Ministerstwa, } \\
\text { Agencje rządowe) }\end{array}$} & TAK & \\
\hline & NIE & \\
\hline \multirow{2}{*}{$\begin{array}{l}\text { Samorządy innych } \\
\text { województw } \\
\text { w Polsce }\end{array}$} & TAK & \multirow[t]{2}{*}{ - jakich województw? które departamenty? } \\
\hline & NIE & \\
\hline \multirow{2}{*}{$\begin{array}{l}\text { Publiczne szkoły } \\
\text { wyższe }\end{array}$} & TAK & \\
\hline & NIE & \\
\hline \multirow{2}{*}{$\begin{array}{l}\text { Publiczne Ośrodki } \\
\text { Naukowo- } \\
\text {-Badawcze }\end{array}$} & TAK & \\
\hline & NIE & \\
\hline \multirow{2}{*}{$\begin{array}{l}\text { Organizacje } \\
\text { międzynarodowe }\end{array}$} & TAK & \\
\hline & NIE & \\
\hline \multirow{2}{*}{$\begin{array}{l}\text { Regiony innych } \\
\text { państw }\end{array}$} & TAK & \\
\hline & NIE & \\
\hline
\end{tabular}


8. Proszę wskazać 3 najważniejsze czynniki, które skłaniają Departament do nawiązywania partnerskich relacji z wymienionymi niżej podmiotami publicznymi.

ANKIETER: wręczamy badanemu kartę $\boldsymbol{E} z$ odpowiedziami, a następnie wpisujemy $w$ kolejne kolumny obok poniższych stwierdzeń odpowiedź wskazana jako 1, 2 i 3. Zapisujemy odpowiedzi badanych tylko w odniesieniu do podmiotów wymienionych przez respondenta $w$ odpowiedzi na pytanie 7.

\begin{tabular}{|c|c|c|c|c|c|c|}
\hline Czynniki & $\begin{array}{l}\text { JST z ob- } \\
\text { szaru wo- } \\
\text { jewódz- } \\
\text { twa i ich } \\
\text { związki }\end{array}$ & $\begin{array}{l}\text { Wojewo- } \\
\text { da i jego } \\
\text { służby }\end{array}$ & $\begin{array}{l}\text { Admini- } \\
\text { stracja } \\
\text { rządowa } \\
\text { (mini- } \\
\text { sterstwa, } \\
\text { agencje) }\end{array}$ & $\begin{array}{l}\text { Samorzą- } \\
\text { dy innych } \\
\text { woje- } \\
\text { wództw }\end{array}$ & $\begin{array}{l}\text { Publiczne } \\
\text { szkoły } \\
\text { wyższe, } \\
\text { JNB }\end{array}$ & $\begin{array}{l}\text { Organiza- } \\
\text { cje mię- } \\
\text { dzyna- } \\
\text { rodowe, } \\
\text { regiony } \\
\text { innych } \\
\text { państw }\end{array}$ \\
\hline $\begin{array}{l}\text { Presja podmiotów } \\
\text { publicznych z regionu } \\
\text { chcących współdziałać } \\
\text { (potencjalni partnerzy } \\
\text { sami zabiegają u dy- } \\
\text { rekcji departamentu } \\
\text { o wspólne przedsię- } \\
\text { wzięcia) }\end{array}$ & & & & & & \\
\hline $\begin{array}{l}\text { Presja na departament } \\
\text { ze strony członków } \\
\text { zarządu województwa, } \\
\text { aby nawiązywać szersze } \\
\text { kontakty z potencjalny- } \\
\text { mi partnerami publicz- } \\
\text { nymi }\end{array}$ & & & & & & \\
\hline $\begin{array}{l}\text { Obowiązek współ- } \\
\text { działania wynikający } \\
\text { z przepisów krajowych } \\
\text { (ustawa o samorządzie } \\
\text { województwa) }\end{array}$ & & & & & & \\
\hline $\begin{array}{l}\text { Zasada partnerstwa } \\
\text { wynikająca z przepisów } \\
\text { europejskich (Rozporzą- } \\
\text { dzenie } 1083 / 06 \text { ) }\end{array}$ & & & & & & \\
\hline $\begin{array}{l}\text { Chęć pozyskania ze- } \\
\text { wnętrznych środków }\end{array}$ & & & & & & \\
\hline $\begin{array}{l}\text { Większe możliwości } \\
\text { realizacji postawionych } \\
\text { przed samorządem } \\
\text { zadań }\end{array}$ & & & & & & \\
\hline
\end{tabular}




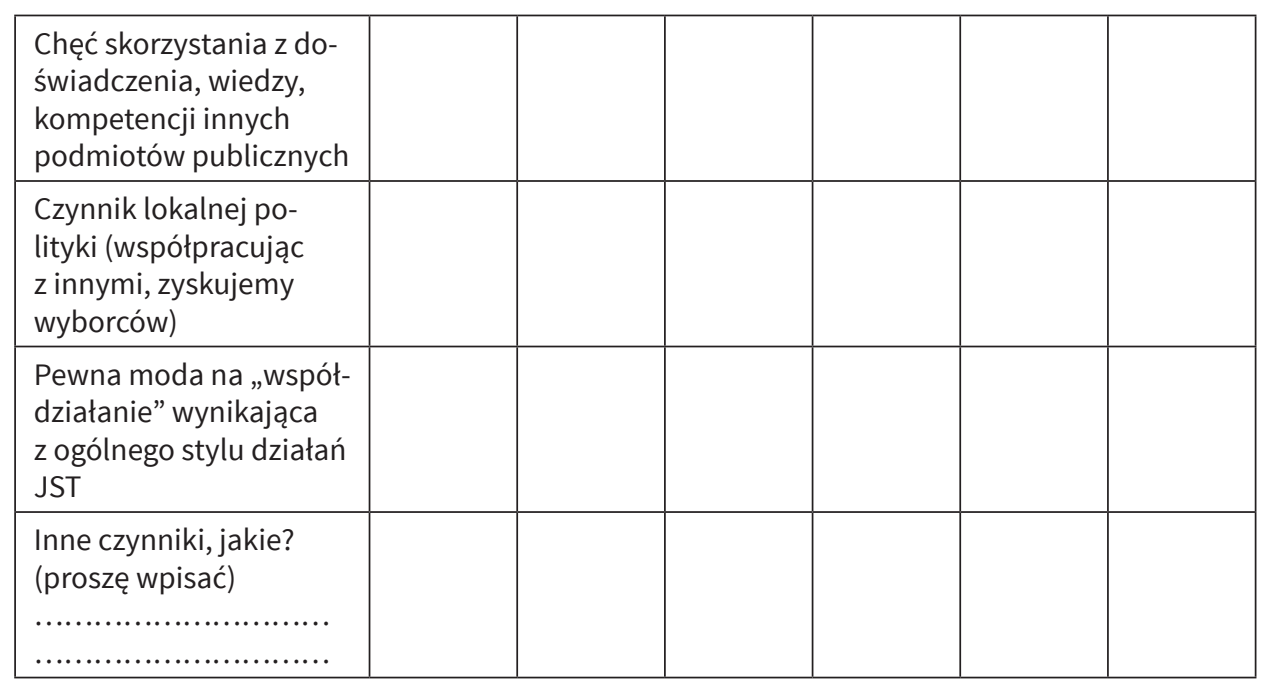

9. A teraz proszę wymienić 3 najważniejsze czynniki, które utrudniają Pana/Pani Departamentowi nawiązywanie partnerskich relacji z wymienionymi niżej podmiotami publicznymi.

ANKIETER: wręczamy badanemu kartę $\boldsymbol{F} z$ odpowiedziami, a następnie wpisujemy w kolejne kolumny obok poniższych stwierdzeń odpowiedź wskazana jako 1, 2 i 3. Zapisujemy odpowiedzi badanych tylko $w$ odniesieniu do podmiotów wymienionych przez respondenta $w$ odpowiedzi na pytanie 7.

\begin{tabular}{|c|c|c|c|c|c|c|}
\hline Czynniki & $\begin{array}{l}\text { JST } \\
\text { z obsza- } \\
\text { ru wo- } \\
\text { jewódz- } \\
\text { twa i ich } \\
\text { związki }\end{array}$ & $\begin{array}{l}\text { Woje- } \\
\text { woda } \\
\text { i jego } \\
\text { służby }\end{array}$ & $\begin{array}{l}\text { Admini- } \\
\text { stracja } \\
\text { rządo- } \\
\text { wa (mi- } \\
\text { nister- } \\
\text { stwa, } \\
\text { agencje) }\end{array}$ & $\begin{array}{l}\text { Samo- } \\
\text { rządy } \\
\text { innych } \\
\text { woje- } \\
\text { wództw }\end{array}$ & $\begin{array}{l}\text { Pu- } \\
\text { bliczne } \\
\text { szkoły } \\
\text { wyższe, } \\
\text { JNB }\end{array}$ & $\begin{array}{c}\text { Orga- } \\
\text { nizacje } \\
\text { między- } \\
\text { naro- } \\
\text { dowe, } \\
\text { regiony } \\
\text { innych } \\
\text { państw }\end{array}$ \\
\hline $\begin{array}{l}\text { Brak chęci współpracy } \\
\text { po stronie departa- } \\
\text { mentu }\end{array}$ & & & & & & \\
\hline $\begin{array}{l}\text { Nieprzygotowanie pra- } \\
\text { cowników departamen- } \\
\text { tu do nawiązywania } \\
\text { i prowadzenia zewnętrz- } \\
\text { nej współpracy }\end{array}$ & & & & & & \\
\hline $\begin{array}{l}\text { Brak „zielonego świa- } \\
\text { tła” ze strony zarządu } \\
\text { do nawiązywania } \\
\text { współpracy zewnętrznej }\end{array}$ & & & & & & \\
\hline
\end{tabular}




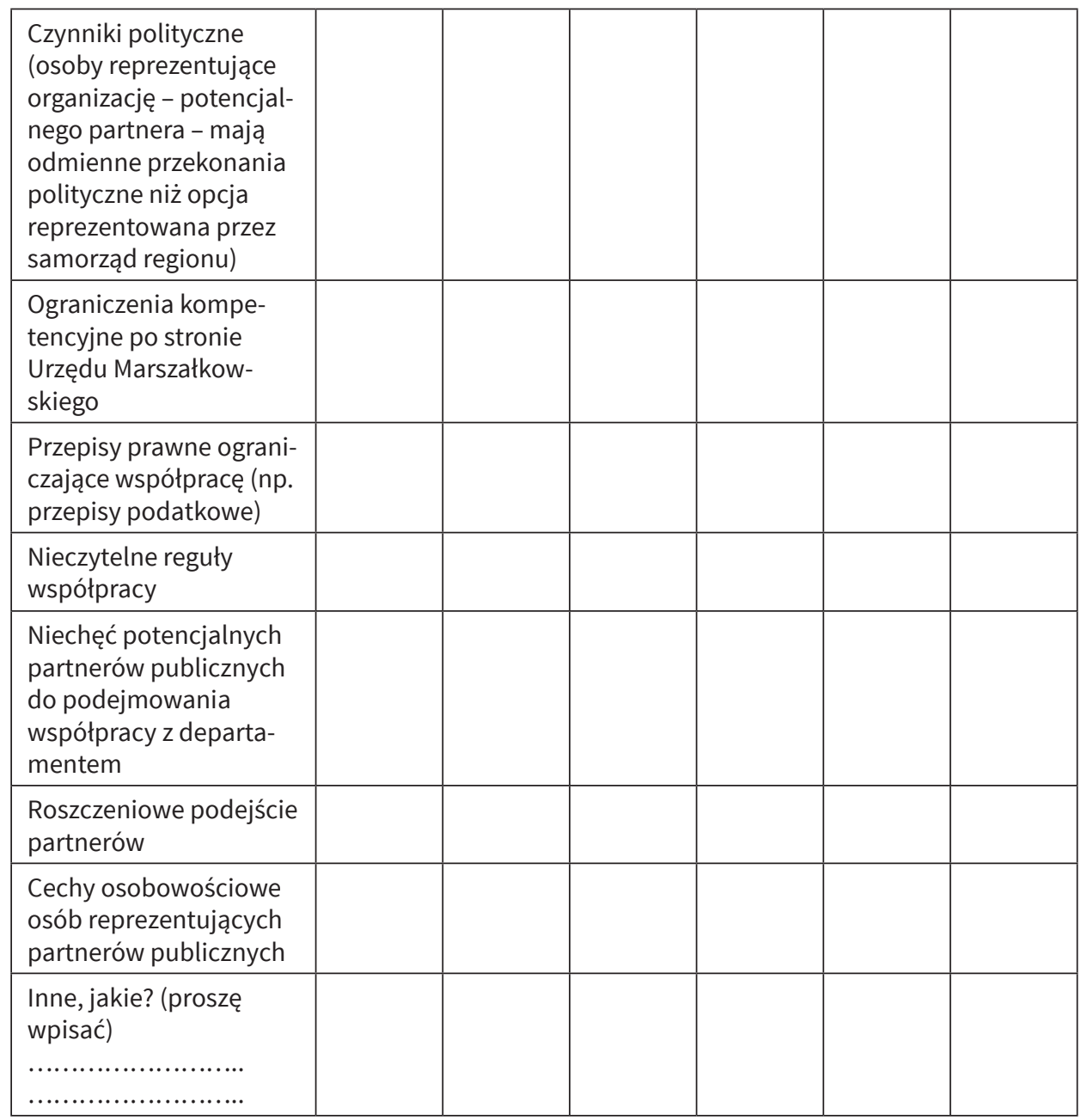

10. Proszę opisać i uzasadnić maksymalnie 3 przykłady partnerstwa podjętego przez Departament z podmiotami publicznymi.

ANKIETER: opis współpracy powinien zawierać jej merytoryczny zakres, formy wspótpracy - powstałe struktury instytucjonalne, częstotliwość kontaktów. Jakie czynniki zadecydowały, że się udało (czynniki sukcesu)?

\begin{tabular}{|l|l|}
\hline \multicolumn{1}{|c|}{ 1. Nazwa podmiotu } & \\
\hline Zakres współpracy, jej długość & \\
\hline Forma współpracy & \\
\hline $\begin{array}{l}\text { Czynniki decydujące o sukcesie } \\
\text { współpracy }\end{array}$ & \\
\hline
\end{tabular}




\begin{tabular}{|l|l|}
\hline \multicolumn{1}{|c|}{ 2. Nazwa podmiotu } & \\
\hline Zakres współpracy, jej długość & \\
\hline Forma współpracy & \\
\hline $\begin{array}{l}\text { Czynniki decydujące o sukcesie } \\
\text { współpracy }\end{array}$ & \\
\hline \multicolumn{1}{|c|}{ 3. Nazwa podmiotu } & \\
\hline Zakres współpracy, jej długość & \\
\hline Forma współpracy & \\
\hline $\begin{array}{l}\text { Czynniki decydujące o sukcesie } \\
\text { współpracy }\end{array}$ & \\
\hline
\end{tabular}

Prosze poprosić o namiary na przedstawicieli tych partnerskich instytucji (nazwiska, mail, tel.) - bowiem nasz projekt obejmuje też wywiady z partnerami.

11. Proszę podać i uzasadnić maksymalnie 3 negatywne przykłady partnerstwa podjętego przez Departament z podmiotami publicznymi.

ANKIETER: opis wspótpracy powinien zawierać jej merytoryczny zakres, formy wspótpracy - powstałe struktury instytucjonalne, częstotliwość kontaktów. Jakie czynniki zadecydowały, że się nie udało (czynniki porażki)?

Prosze poprosić o namiary na przedstawicieli tych partnerskich instytucji (nazwiska, mail, tel.) - bowiem nasz projekt obejmuje te ż wywiady z partnerami.

12. Jakie powinny być 3 najważniejsze cechy idealnego partnera publicznego, z którym samorząd regionu byłby skłonny nawiązać długookresowe - partnerskie relacje.

ANKIETER: wręczamy badanemu kartę $\boldsymbol{G} z$ odpowiedziami, a następnie wpisujemy obok poniższych stwierdzeń odpowiedź wskazana jako 1, 2 i 3.

- Poważany

- Bogaty

- Uczciwy

- Lojalny

- Wiarygodny

- Odpowiedzialny

- Z dużym doświadczeniem

- Otwarty
- O podobnych poglądach politycznych

- O szerokich kompetencjach

- Sprawdzony we wcześniejszej współpracy

- Chętny do współpracy

- Stabilny finansowo

- Stabilny politycznie

- Przyjazna osobowość partnerów

- Inne czynniki, jakie? 


\section{WSPÓŁPRACA SAMORZĄDU REGIONU Z SAMORZĄDAMI LOKALNYMI}

ANKIETER: a teraz chciałabym przejść do współdziałania z jednostkami samorządu lokalnego na terenie województwa wielkopolskiego jako podmiotów publicznych majacych wymierny wpływ na rozwój regionu. Chciałabym Pana/Panią prosić o wyrażenie swojej opinii na temat relacji samorzadu regionu z samorzadami lokalnymi. Prosze tu uwzglednić nie tylko doświadczenia wynikające z pracy własnego departamentu, ale całego urzędu marszatkowskiego.

13. Proszę zaznaczyć wszystkie istotne obszary, którymi zarządzanie na szczeblu województwa w sposób szczególny wymaga współdziałania samorządu regionu z samorządami lokalnymi.

ANKIETER: wręczamy badanemu kartę $\boldsymbol{H}$ z listą stwierdzeń, a następnie zaznaczamy odpowiedzi badanego.

- Rozwój przedsiębiorczości

- Pozyskiwanie środków europejskich

- Polityka innowacyjna

- Promocja gminy/powiatu

- Rozwój funkcji turystycznych

- Pozyskiwanie turystów

- Pozyskiwanie inwestorów zewnętrznych

- Rozwijanie infrastruktury

- Edukacja

- Ochrona środowiska

- Inne, jakie?

14. Proszę wymienić pełne nazwy wszystkich struktur instytucjonalnych (np. Rada..., Komitet..., Konwent..., Zespół koordynacyjny... itp.), w ramach których samorząd województwa współpracuje z samorządami lokalnymi.

ANKIETER: $w$ razie konieczności proszę pomóc respondentowi wskazać przykłady: Komitet Monitorujący RPO, Konwent Starostów...

15. Funkcjonowanie której z wyżej wymienionych struktur ocenia Pan/Pani najlepiej ze względu na realny wpływ samorządów lokalnych na politykę rozwoju regionu? 
16. W jakim stopniu Zarząd Województwa Wielkopolskiego angażuje się we współdziałanie z samorządami lokalnymi regionu (gminami i powiatami)?

\begin{tabular}{|c|c|}
\hline $\begin{array}{l}\text { Bardzo } \\
\text { dużym }\end{array}$ & Dużym \\
\hline
\end{tabular}

17. W jakim stopniu Zarząd Województwa angażuje się w dialog ze Stowarzyszeniem Gmin i Powiatów Wielkopolski?

$\begin{array}{cccccc}\begin{array}{c}\text { Bardzo } \\ \text { dużym }\end{array} & \text { Dużym } & \text { Średnim } & \text { Małym } & \begin{array}{c}\text { Bardzo } \\ \text { małym }\end{array} & \begin{array}{c}\text { Trudno } \\ \text { powiedzieć }\end{array} \\ \bigcirc & \bigcirc & \bigcirc & \bigcirc & \bigcirc & \bigcirc\end{array}$

18. W jakim stopniu Zarząd Województwa angażuje się w dialog z Konwentem Starostów Województwa Wielkopolskiego?

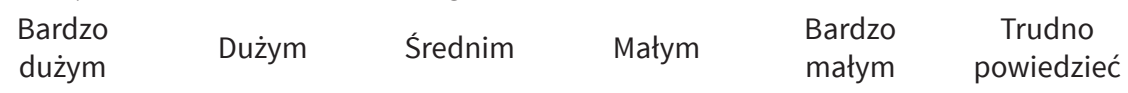

19. Proszę wskazać wszystkie konieczne Pana zdaniem usprawnienia, które poszerzałyby współpracę władz regionu z samorządami lokalnymi w kontekście prowadzenia polityki rozwoju.

ANKIETER: wręczamy badanemu kartę I $z$ listą stwierdzeń, a następnie zaznaczamy odpowiedzi badanego.

\begin{tabular}{|c|}
\hline Czynniki \\
\hline $\begin{array}{l}\text { Powiązania samorządu regionalnego z samorządami lokalnymi powinny przybierać } \\
\text { bardziej formalny charakter }\end{array}$ \\
\hline $\begin{array}{l}\text { Powołanie zespołów zadaniowych przy marszałku województwa (w obszarach } \\
\text { merytorycznych) składających się m.in. z przedstawicieli samorządów lokalnych }\end{array}$ \\
\hline $\begin{array}{l}\text { Przygotowanie i realizacja cyklu seminariów dla samorządowców z regionu mających } \\
\text { na celu kształtowanie świadomości władz lokalnych na temat korzyści współdziałania } \\
\text { jednostek samorządu terytorialnego }\end{array}$ \\
\hline Marszałek województwa powinien obejmować patronatem więcej inicjatyw lokalnych \\
\hline $\begin{array}{l}\text { Przedstawiciele zarządu województwa powinni częściej uczestniczyć w wydarzeniach } \\
\text { lokalnych na terenie województwa wielkopolskiego }\end{array}$ \\
\hline $\begin{array}{l}\text { Poszczególne departamenty urzędu marszałkowskiego powinny w praktycznych } \\
\text { działaniach więcej uwagi poświęcić inicjowaniu i prowadzeniu wspólnych przedsięwzięć } \\
\text { z samorządami lokalnymi }\end{array}$ \\
\hline $\begin{array}{l}\text { Powiązania samorządu regionalnego z samorządami lokalnymi powinny przybierać } \\
\text { bardziej nieformalny charakter }\end{array}$ \\
\hline Inne propozycje, jakie? \\
\hline
\end{tabular}




\section{WSPÓtPRACA SAMORZĄDU REGIONALNEGO Z PODMIOTAMI NIEPUBLICZNYMI}

A teraz przejdziemy do opisu relacji Pana/Pani departamentu z podmiotami niepublicznymi. W badaniu przyjęliśmy, że potencjalnymi partnerami departamentu po stronie podmiotów niepublicznych (społecznych i prywatnych) będa takie instytucje, jak samorząd gospodarczy, samorzad zawodowy, organizacje pozarządowe, prywatne szkoły wyższe, prywatne ośrodki $B+R$, indywidualne przedsiębiorstwa.

20. Proszę wskazać, z którymi z poniższych podmiotów niepublicznych Pana/Pani Departament współpracuje przy realizacji powierzonych mu zadań. Tam, gdzie jest to możliwe, proszę podać nazwy podmiotów.

\begin{tabular}{|c|c|c|}
\hline $\begin{array}{c}\text { Podmioty } \\
\text { niepubliczne }\end{array}$ & Odpowiedzi & Nazwy podmiotów \\
\hline \multirow{2}{*}{$\begin{array}{l}\text { Samorząd } \\
\text { gospodarczy }\end{array}$} & TAK & \\
\hline & NIE & \\
\hline \multirow{2}{*}{$\begin{array}{l}\text { Samorząd } \\
\text { zawodowy }\end{array}$} & TAK & \\
\hline & NIE & \\
\hline \multirow{2}{*}{$\begin{array}{l}\text { Organizacje } \\
\text { pozarządowe }\end{array}$} & TAK & \\
\hline & NIE & \\
\hline \multirow{2}{*}{$\begin{array}{l}\text { Prywatne szkoły } \\
\text { wyższe }\end{array}$} & TAK & \\
\hline & NIE & \\
\hline \multirow{2}{*}{$\begin{array}{l}\text { Prywatne ośrodki } \\
B+R\end{array}$} & TAK & \\
\hline & NIE & \\
\hline \multirow{2}{*}{$\begin{array}{l}\text { Indywidualne } \\
\text { przedsiębiorstwa }\end{array}$} & TAK & \\
\hline & NIE & \\
\hline
\end{tabular}

21. Proszę wskazać 3 najważniejsze czynniki, które skłaniają Departament do nawiązywania partnerskich relacji z wymienionymi niżej podmiotami niepublicznymi?

ANKIETER: wręczamy badanemu kartę $\boldsymbol{J}$ z odpowiedziami, a następnie wpisujemy $w$ kolejne kolumny obok poniższych stwierdzeń odpowiedź wskazana jako 1, 2 i 3. Zapisujemy odpowiedzi badanych tylko w odniesieniu do podmiotów wymienionych przez respondenta w odpowiedzi na pytanie 20. 


\begin{tabular}{|c|c|c|c|c|c|c|}
\hline Czynniki & $\begin{array}{l}\text { Samo- } \\
\text { rząd } \\
\text { gospo- } \\
\text { darczy }\end{array}$ & $\begin{array}{l}\text { Samo- } \\
\text { rząd } \\
\text { zawo- } \\
\text { dowy }\end{array}$ & $\begin{array}{c}\text { Orga- } \\
\text { nizacje } \\
\text { poza- } \\
\text { rządowe } \\
\text { (NGO) }\end{array}$ & $\begin{array}{l}\text { Prywat- } \\
\text { ne szkoły } \\
\text { wyższe }\end{array}$ & $\begin{array}{l}\text { Pry- } \\
\text { watne } \\
\text { ośrodki } \\
B+R\end{array}$ & $\begin{array}{l}\text { Indywi- } \\
\text { dualne } \\
\text { przedsię- } \\
\text { biorstwa }\end{array}$ \\
\hline $\begin{array}{l}\text { Presja podmiotów nie- } \\
\text { publicznych z regionu } \\
\text { chcących współdziałać } \\
\text { (potencjalni partnerzy sami } \\
\text { zabiegają u dyrekcji depar- } \\
\text { tamentu o wspólne przed- } \\
\text { sięwzięcia) }\end{array}$ & & & & & & \\
\hline $\begin{array}{l}\text { Presja na departament ze } \\
\text { strony członków zarządu } \\
\text { województwa, aby nawią- } \\
\text { zywać szersze kontakty } \\
\text { z potencjalnymi partnerami } \\
\text { prywatnymi }\end{array}$ & & & & & & \\
\hline $\begin{array}{l}\text { Obowiązek współdziałania } \\
\text { wynikający z przepisów } \\
\text { krajowych (ustawa o samo- } \\
\text { rządzie województwa) }\end{array}$ & & & & & & \\
\hline $\begin{array}{l}\text { Zasada partnerstwa wyni- } \\
\text { kająca z przepisów euro- } \\
\text { pejskich (Rozporządzenie } \\
\text { 1083/06) }\end{array}$ & & & & & & \\
\hline $\begin{array}{l}\text { Chęć pozyskania zewnętrz- } \\
\text { nych środków }\end{array}$ & & & & & & \\
\hline $\begin{array}{l}\text { Większe możliwości reali- } \\
\text { zacji postawionych przed } \\
\text { samorządem zadań }\end{array}$ & & & & & & \\
\hline $\begin{array}{l}\text { Chęć skorzystania z do- } \\
\text { świadczenia, wiedzy, kom- } \\
\text { petencji innych podmiotów } \\
\text { niepublicznych }\end{array}$ & & & & & & \\
\hline $\begin{array}{l}\text { Czynnik lokalnej polityki } \\
\text { (współpracując z innymi, } \\
\text { zyskujemy wyborców) }\end{array}$ & & & & & & \\
\hline $\begin{array}{l}\text { Pewna moda na „współdzia- } \\
\text { łanie” wynikająca z ogólne- } \\
\text { go stylu działań JST }\end{array}$ & & & & & & \\
\hline $\begin{array}{l}\text { Inne czynniki, jakie? (proszę } \\
\text { wpisać) }\end{array}$ & & & & & & \\
\hline
\end{tabular}




\section{A teraz proszę wskazać 3 najważniejsze, które utrudniają Pana/Pani Departamen-} towi nawiązywanie partnerskich relacji z wymienionymi niżej podmiotami niepublicznymi.

ANKIETER: wręczamy badanemu kartę $\boldsymbol{K}$ z odpowiedziami, a następnie wpisujemy $w$ kolejne kolumny obok poniższych stwierdzeń odpowiedź wskazana jako 1, 2 i 3. Zapisujemy odpowiedzi badanych tylko $w$ odniesieniu do podmiotów wymienionych przez respondenta $w$ odpowiedzi na pytanie 20.

\begin{tabular}{|c|c|c|c|c|c|c|}
\hline Czynniki & $\begin{array}{l}\text { Samo- } \\
\text { rząd } \\
\text { gospo- } \\
\text { darczy }\end{array}$ & $\begin{array}{l}\text { Samo- } \\
\text { rząd } \\
\text { zawo- } \\
\text { dowy }\end{array}$ & $\begin{array}{l}\text { Orga- } \\
\text { nizacje } \\
\text { poza- } \\
\text { rzą- } \\
\text { dowe } \\
\text { (NGO) }\end{array}$ & $\begin{array}{l}\text { Pry- } \\
\text { watne } \\
\text { szkoły } \\
\text { wyższe }\end{array}$ & $\begin{array}{l}\text { Pry- } \\
\text { watne } \\
\text { ośrodki } \\
B+R\end{array}$ & $\begin{array}{l}\text { Indywi- } \\
\text { dualne } \\
\text { przed- } \\
\text { siębior- } \\
\text { stwa }\end{array}$ \\
\hline \multicolumn{7}{|l|}{$\begin{array}{l}\text { Brak chęci współpracy po } \\
\text { stronie departamentu }\end{array}$} \\
\hline \multicolumn{7}{|l|}{$\begin{array}{l}\text { Nieprzygotowanie pra- } \\
\text { cowników departamentu } \\
\text { do nawiązywania i prowa- } \\
\text { dzenia zewnętrznej współ- } \\
\text { pracy }\end{array}$} \\
\hline \multicolumn{7}{|l|}{$\begin{array}{l}\text { Brak „zielonego światła” } \\
\text { ze strony zarządu do na- } \\
\text { wiązywania współpracy } \\
\text { zewnętrznej }\end{array}$} \\
\hline \multicolumn{7}{|l|}{$\begin{array}{l}\text { Czynniki polityczne (osoby } \\
\text { reprezentujące organizację } \\
\text { - potencjalnego partnera } \\
\text { - mają odmienne przeko- } \\
\text { nania polityczne niż opcja } \\
\text { reprezentowana przez } \\
\text { samorząd regionu) }\end{array}$} \\
\hline \multicolumn{7}{|l|}{$\begin{array}{l}\text { Ograniczenia kompeten- } \\
\text { cyjne po stronie urzędu } \\
\text { marszałkowskiego }\end{array}$} \\
\hline \multicolumn{7}{|l|}{$\begin{array}{l}\text { Przepisy prawne ograni- } \\
\text { czające współpracę (np. } \\
\text { przepisy podatkowe) }\end{array}$} \\
\hline \multicolumn{7}{|l|}{$\begin{array}{l}\text { Nieczytelne reguły współ- } \\
\text { pracy }\end{array}$} \\
\hline $\begin{array}{l}\text { Niechęć potencjalnych } \\
\text { partnerów prywatnych do } \\
\text { podejmowania współpracy } \\
\text { z departamentem }\end{array}$ & & & & & & \\
\hline
\end{tabular}




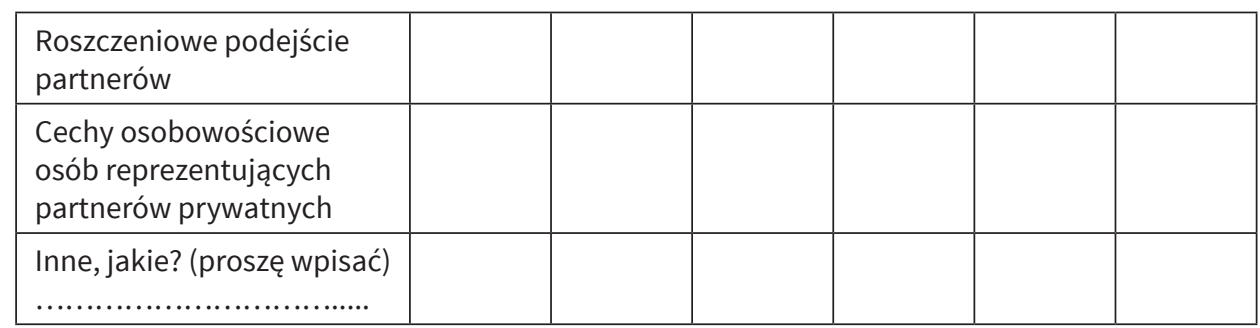

23. Proszę opisać i uzasadnić maksymalnie 3 przykłady partnerstwa podjętego przez Departament z podmiotami niepublicznymi.

ANKIETER: opis współpracy powinien zawierać jej merytoryczny zakres, formy wspótpracy - powstałe struktury instytucjonalne, częstotliwość kontaktów). Jakie czynniki zadecydowały, że się udało (czynniki sukcesu)?

Proszę dopytać, czy respondent posiada „osobisty kontakt” (a nie tylko stużbowy) z osobami reprezentującymi partnerów (np. znaja się ze szkoły, wcześniej pracowali razem, graja razem $w$ piłkę...).

\begin{tabular}{|l|l|}
\hline \multicolumn{1}{|c|}{ 1. Nazwa podmiotu } & \\
\hline Zakres współpracy & \\
\hline Forma współpracy & \\
\hline $\begin{array}{l}\text { Czynniki decydujące o sukcesie } \\
\text { współpracy }\end{array}$ & \\
\hline \multicolumn{1}{|c|}{ 2. Nazwa podmiotu } & \\
\hline Zakres współpracy & \\
\hline Forma współpracy & \\
\hline $\begin{array}{l}\text { Czynniki decydujące o sukcesie } \\
\text { współpracy }\end{array}$ & \\
\hline 3. Nazwa podmiotu & \\
\hline Zakres współpracy & \\
\hline Forma współpracy & \\
\hline $\begin{array}{l}\text { Czynniki decydujące o sukcesie } \\
\text { współpracy }\end{array}$ & \\
\hline
\end{tabular}

24. Proszę podać i uzasadnić maksymalnie 3 negatywne przykłady partnerstwa podjętego przez Departament z podmiotami niepublicznymi.

ANKIETER: opis współpracy powinien zawierać jej merytoryczny zakres, formy wspótpracy - powstałe struktury instytucjonalne, częstotliwość kontaktów). Jakie czynniki zadecydowały, że się nie udało (czynniki porazki)? 
25. Jakie powinny być 3 najważniejsze cechy idealnego partnera niepublicznego, z którym samorząd regionu byłby skłonny nawiązać długookresowe - partnerskie relacje. ANKIETER: wręczamy badanemu kartę L $z$ odpowiedziami, a następnie wpisujemy obok poniższych stwierdzeń odpowiedź wskazana jako 1, 2 i 3.

- Poważany

- Bogaty

- Uczciwy

- Lojalny

- Wiarygodny

- Odpowiedzialny

- Z dużym doświadczeniem

- Otwarty
- O podobnych poglądach politycznych

- O szerokich kompetencjach

- Sprawdzony we wcześniejszej współpracy

- Chętny do współpracy

- Stabilny finansowo

- Stabilny politycznie

- Przyjazna osobowość partnerów

- Inne czynniki, jakie?

26. Jak Pan/Pani ocenia wpływ polityki na działania urzędu marszałkowskiego?

27. Czy apolityczny urząd jest realny w polskich warunkach?

\section{Dziękujemy za udział w badaniu}

\section{METRYCZKA}

DEPARTAMENT:

CZAS TRWANIA WYWIADU:

STANOWISKO RESPONDENTA: $\quad$ 1. Dyrektor $\quad 2$. Zastępca dyrektora

PŁEĆ RESPONDENTA: M K

WIEK RESPONDENTA:
- do 30
- $31-40$
- $41-50$
- $51-60$
- 61-powyżej

BADANE JEDNOSTKI ORGANIZACYJNE:

1 - RYNKOWE (RYN)

2 - SEKTOROWE (SEK)

3 - ADMINISTRACYJNE (ADM) 
Załącznik 6.1. Lista pytań do wywiadu otwartego

$$
\text { Część } 3 \text { wywiadu - relacje miasta i regionu }
$$

1. Jakie mogą być korzyści dla regionu (urzędu marszałkowskiego) ze współpracy ze stolicą regionu?

2. Jakie mogą być korzyści dla miasta ze współpracy z urzędem marszałkowskim?

3. Co utrudnia nawiązywanie relacji partnerskich z miastem?

4. Czy i w jakich sytuacjach są Państwo angażowani w proces tworzenia polityk miasta?

4a. Czy i w jakich sytuacjach angażujecie Państwo stolicę regionu w tworzenie polityk rozwojowych adresowanych do całego regionu?

5. W jakiej formule prowadzone są wspólne prace?

6. Jak ocenia Pan/Pani poziom otwartości urzędu na sugestie dotyczące polityki przyciągania inwestorów/turystów/studentów/miejscowych przedsiębiorców?

7. Czy może Pan/Pani podać przykład pozytywnej współpracy z miastem podjętej w ostatnim czasie? Czego dotyczyła, jaka była formuła współpracy?

8. Kto jest inicjatorem tej współpracy - region, miasto, inna instytucja?

9. Czy współpraca z miastem odbywa się poprzez utworzenie stałych więzi, struktur partnerskich - jakie to struktury/sieci/partnerstwa?

10. Jak ocenia Pan/Pani efektywność współpracy z miastem w realizowaniu polityk prorozwojowych dotyczących przyciągania turystów, inwestorów, potencjalnych studentów i tworzenia otoczenia dla przedsiębiorców lokalnych?

11. Jak ocenia Pan/Pani jakość bieżących relacji roboczych, które są elementem tej współpracy?

12. Na ile w wyniku współpracy została poszerzona perspektywa regionu w odniesieniu do zjawisk i problemów będących przedmiotem wspólnych działań?

13. Na ile w wyniku współpracy doszło do zwiększenia zaangażowania we wspólne przedsięwzięcia z partnerami sieci w postaci np. wspólnych projektów, kontraktów, wzajemnego świadczenia usług?

14. Na ile w wyniku współpracy relacje między regionem a miastem stały się partnerskie?

15. Kto Pana/Pani zdaniem ma pozycję dominującą w relacjach dwustronnych region-miasto?

16. Czym miasto i region dzielą się w ramach współpracy?

Źródło: Część 3 kwestionariusza wywiadu pogłębionego realizowanego w rynkowych jednostkach organizacyjnych badanych urzędów marszałkowskich, opracowanie: J. Anders-Morawska, W. Rudolf w ramach projektu: Marketing jako operacyjne rozwinięcie koncepcji governance w zarządzaniu publicznym. 
Załącznik 6.2. Nazwy regionów i miast partnerskich, spełniających kryteria zgodności

\begin{tabular}{|c|c|}
\hline Region/miasto & $\begin{array}{c}\text { Przypadki, w których zachodzi zgodność regionu partnerskiego z miastem } \\
\text { partnerskim stolicy regionu }\end{array}$ \\
\hline Łódzkie & \multirow{2}{*}{$\begin{array}{l}\text { Region Murcji - Murcja; Region Örebro - Örebro; Obwód Odeski - Odessa; } \\
\text { Region Csongrad - Csongrad; Land Badenia-Wirtembergia - Stuttgart }\end{array}$} \\
\hline Łódź & \\
\hline Małopolskie & \multirow{2}{*}{ Obwód Lwowski - Lwów; Prowincja Jiangsu - Nankin; Land Tyrol - Innsbruck } \\
\hline Kraków & \\
\hline Podkarpackie & \multirow{2}{*}{$\begin{array}{l}\text { Obwód Lwowski - Lwów; Obwód Wołyński - Wołyń; Kraj Koszycki - Koszyce; } \\
\text { Obwód Iwano-Frankiwsk - Iwano-Frankiwsk; Szabolcs-Szatmar-Bereg - } \\
\text { Nyíregyháza; Region Autonomiczny Kuangsi-Czuang - Nanning }\end{array}$} \\
\hline Rzeszów & \\
\hline $\begin{array}{l}\text { Warmińsko- } \\
\text { mazurskie }\end{array}$ & \multirow[t]{2}{*}{ Obwód Kaliningradzki - Kaliningrad; Województwo Halland - Halmstad } \\
\hline Olsztyn & \\
\hline
\end{tabular}

Źródło: opracowanie własne na podstawie danych pozyskanych z urzędów marszałkowskich i urzędów miejskich. 


\section{Spis tabel, rysunków i załączników}

Tabela 2.1. Perspektywy badań nad marketingiem terytorialnym

Tabela 2.2. Rodzaje relacji marketingowych i ich charakterystyka

Tabela 3.1. Poziomy relacji międzyorganizacyjnych

Tabela 3.2. Typy powiązań organizacji publicznej z jej interesariuszami instytucjonalnymi

Tabela 4.1. Obszary oceny responsywności badanych organizacji terytorialnych techniką „tajemniczy klient” (mystery client)

Tabela 6.1. Przedział zmienności syntetycznej miary potencjału regionów z podziałem na trzy przedziały klasowe

Tabela 6.2. Cechy statystyczne opisujące zasoby inwestycyjne terytoriów ważne dla inwestorów

Tabela 6.3. Syntetyczna miara dla udziału zasobów stolicy w zasobach regionu ogółem na rynku inwestycyjnym

Tabela 6.4. Poziomy miernika potencjału stolicy w regionie na rynku inwestycyjnym

Tabela 6.5. Cechy statystyczne opisujące zasoby turystyczne terytoriów

Tabela 6.6. Syntetyczna miara dla udziału zasobów stolicy w zasobach regionu ogółem na rynku turystycznym

Tabela 6.7. Poziomy miernika potencjału stolicy $w$ regionie na rynku turystycznym

Tabela 6.8. Syntetyczna miara dla udziału zasobów stolicy w zasobach regionu ogółem na rynku akademickim

Tabela 6.9. Poziomy miernika potencjału stolicy $w$ regionie na rynku akademickim

Tabela 6.10. Cechy statystyczne wybrane dla określenia udziału stolicy w regionie w zakresie zasobów turystycznych, akademickich i inwestycyjnych

Tabela 6.11. Syntetyczna miara udziału wszystkich zasobów stolicy w zasobach regionu ogółem 
Tabela 6.12. Poziomy miernika potencjału stolicy w regionie na rynkach: inwestycyjnym, turystycznym i akademickim ogółem

Tabela 6.13. Zestawienie wyników klasyfikacji regionów z wykorzystaniem miary udziału zasobów stolicy w zasobach regionu ogółem na rynkach: inwestycyjnym, turystycznym, akademickim oraz w ujęciu syntetycznym

Tabela 6.14. Cechy i wagi wykorzystane w ocenie współdziałania region-stolica w procesach marketingowych zorientowanych na użytkowników zewnętrznych

Tabela 6.15. Ocena współdziałania region-miasto przez badanych menedżerów publicznych z urzędów marszałkowskich oraz urzędów miast w zakresie realizacji procesów marketingowych

Tabela 6.16. Logotypy badanych województw i miast w okresie realizacji badania

Tabela 6.17. Miasta i regiony partnerskie badanych województw i miast w ujęciu ilościowym

Tabela 6.18. Nazwy miast - stolic województw w dokumentach strategicznych i operacyjnych dotyczących rozwoju poszczególnych województw

Rysunek 2.1. Łączna liczba badanych terminów związanych z rynkiem użytych w słowach kluczowych artykułów naukowych badanego zbioru czasopism z zakresu sektora publicznego w latach 1995-2014

Rysunek 2.2. Dynamika częstości występowania badanych terminów związanych z rynkiem użytych w słowach kluczowych artykułów naukowych badanego zbioru czasopism z zakresu sektora publicznego w latach 1995-2014

Rysunek 2.3. Dynamika wzrostu częstości występowania terminów związanych z rynkiem w słowach kluczowych artykutów naukowych badanego zbioru czasopism z zakresu sektora publicznego w latach 1995-2014 z podziałem na cztery okresy

Rysunek 2.4. Model marketingu w sektorze publicznym

Rysunek 2.5. Wczesne szkoły badań nad marketingiem relacji 59

Rysunek 2.6. Dwoistość marketingu relacji 60

Rysunek 2.7. Organizacja (firma) i jej relacje partnerskie 62

$\begin{array}{lll}\text { Rysunek 2.8. } & \text { Model interesariuszy przedsiębiorstwa } & 67\end{array}$

Rysunek 2.9. Marketing interesariuszy jako nowy wymiar marketingu relacji

Rysunek 3.1. Łączna liczba badanych terminów związanych z relacjami użytych w słowach kluczowych artykułów 
naukowych badanego zbioru czasopism z zakresu sektora publicznego w latach 1995-2014

Rysunek 3.2. Dynamika częstości występowania badanych terminów związanych z relacjami w słowach kluczowych artykułów naukowych badanego zbioru czasopism z zakresu sektora publicznego w latach 1995-2014

Rysunek 3.3. Dynamika wzrostu częstości występowania badanych terminów związanych z relacjami użytych w słowach kluczowych artykułów naukowych badanego zbioru czasopism z zakresu sektora publicznego w latach 1995-2014 z podziałem na cztery okresy

Rysunek 3.4. Wymiar przestrzenny relacji partnerskich 98

Rysunek 3.5. Wymiary relacji partnerskich 99

$\begin{array}{lll}\text { Rysunek 4.1. } & \text { Etapy prowadzonych badań } & 116\end{array}$

Rysunek 4.2. Model sześciu rynków dla OT na szczeblu regionu 120

Rysunek 4.3. Wielokrotne studium przypadku dla relacji region-miasto (stolica regionu)

Rysunek 5.1. Otwartość zewnętrzna całego urzędu marszałkowskiego w ocenie menedżerów według rodzajów departamentów $(n=43)$

Rysunek 5.2. Rola współpracy zewnętrznej w ocenie menedżerów według rodzajów departamentów $(n=43)$

Rysunek 5.3. Współpraca wewnętrzna w urzędzie marszałkowskim w ocenie menedżerów według rodzajów departamentów $(n=43)$

Rysunek 5.4. Ocena otwartości zewnętrznej interesariuszy instytucjonalnych $(n=42)$

Rysunek 5.5. Identyfikacja partnerów publicznych dla jednostek organizacji terytorialnej $(n=43)$

Rysunek 5.6. Identyfikacja partnerów niepublicznych dla organizacji terytorialnej $(n=43)$

Rysunek 5.7. C Czynniki skłaniające do współpracy w opinii menedżerów publicznych $(n=43)$

Rysunek 5.8. Czynniki utrudniające współpracę zewnętrzną w opinii menedżerów publicznych $(n=43)$

Rysunek 5.9. Czynniki sprzyjające współpracy w opinii interesariuszy instytucjonalnych $(n=42)$

Rysunek 5.10. Czynniki skłaniające do współpracy menedżerów publicznych z lokalnymi JST $(n=43)$

Rysunek 5.11. Czynniki utrudniające współpracę menedżerów publicznych z lokalnymi JST $(n=43)$

Rysunek 5.12. Czynniki skłaniające menedżerów publicznych do współpracy z wojewodą oraz podległym mu aparatem administracyjnym $(n=43)$ 
Rysunek 5.13. Czynniki utrudniające menedżerom publicznym współpracę z wojewodą oraz podległym mu aparatem administracyjnym $(n=43)$

Rysunek 5.14. Czynniki skłaniające menedżerów publicznych do współpracy z uczelniami publicznymi $(n=43)$

Rysunek 5.15. Czynniki utrudniające menedżerom publicznym współpracę ze szkołami wyższymi $(n=43)$

Rysunek 5.16. Pożądane przez respondentów cechy idealnego partnera publicznego $(n=43)$

Rysunek 5.17. Pożądane przez respondentów cechy idealnego partnera niepublicznego $(n=43)$

Rysunek 5.18. Obszary merytoryczne współpracy OT na szczeblu regionu z lokalnymi JST $(n=43)$

Rysunek 5.19. Stopień zaangażowania zarządu województwa we współdziałanie z największym związkiem gmin w regionie w ocenie menedżerów OT $(n=43)$

Rysunek 5.20. Stopień zaangażowania zarządu województwa we współdziałanie ze stowarzyszeniem powiatów w ocenie menedżerów OT $(n=43)$

Rysunek 5.21. Stopień zaangażowania zarządu województwa we współpracę z podmiotami instytucjonalnymi z regionu w ocenie interesariuszy instytucjonalnych $(n=42)$

Rysunek 5.22. Obszary współpracy z OT na szczeblu regionu w opinii interesariuszy instytucjonalnych $(n=42)$

Rysunek 5.23. Pożądane obszary współpracy z OT z perspektywy interesariuszy instytucjonalnych $(n=42)$

Rysunek 5.24. Czynniki utrudniające współpracę z organizacją terytorialną $w$ opinii interesariuszy instytucjonalnych $(n=42)$

Rysunek 5.25. Ocena propozycji usprawnień współdziałania region-lokalne JST $(n=43)$

Rysunek 5.26. Model sześciu rynków dla OT na szczeblu województwa samorządowego w kontekście prowadzenia polityki rozwoju

Rysunek 6.1. Model marketingu terytorialnego na szczeblu regionu w ujęciu relacyjnym

Rysunek 6.2. Relacja zasobów niematerialnych (pole szare) do zasobów materialnych terytorium (pole czarne) jako kryterium wyboru terytorium, z perspektywy potencjalnych użytkowników zewnętrznych na poszczególnych rynkach

Rysunek 6.3. Ważony syntetyczny miernik udziału zasobów stolicy w zasobach regionu ogółem na rynku inwestycyjnym

Rysunek 6.4. Ważony syntetyczny miernik udziału zasobów stolicy w zasobach regionu ogółem na rynku turystycznym 
Rysunek 6.5. Ważony syntetyczny miernik udziału zasobów stolicy w zasobach regionu ogółem na rynku akademickim

198

Rysunek 6.6. Syntetyczny miernik potencjału udziału wszystkich badanych zasobów stolicy w zasobach regionu ogółem 201

Rysunek 6.7. Mierniki potencjału rozumianego jako udział zasobów stolicy w zasobach regionu ogółem

Rysunek 6.8. Ranking regionów pod względem udziału zasobów stolicy w zasobach ogółem w regionie według przyjętego miernika na rynkach: inwestycyjnym, turystycznym, akademickim oraz ogółem

Rysunek 6.9. Zestawienie miernika opinii menedżerów oceniających współdziałanie regionu z miastem oraz miernika dotyczącego wybranych rezultatów współdziatania

Rysunek 6.10. Miara potencjału zgodności łącznie dla subiektywnej oceny dokonanej przez menedżerów i obiektywnych rezultatów współdziałania

Rysunek 6.11. Zestawienie mierników potencjału wszystkich zasobów miasta w zasobach regionu ogółem w ujęciu syntetycznym oraz miernika zgodności subiektywnej oceny i obiektywnych rezultatów współdziałania

Załącznik 2.1. Trendy częstości występowania badanych terminów w słowach kluczowych artykułów naukowych w badanym zbiorze czasopism dotyczących sektora publicznego w latach 1995-2014

Złącznik 2.2. Częstość występowania terminów w słowach kluczowych artykułów badanego zbioru czasopism z zakresu sektora publicznego w czterech pięcioletnich okresach

Załącznik 3.1. Linie trendu występowania badanych terminów w słowach kluczowych artykułów naukowych w latach 1995-2014

Załącznik 3.2. Częstość występowania badanych terminów w słowach kluczowych artykułów naukowych badanego zbioru czasopism z zakresu sektora publicznego w okresach pięcioletnich

Załącznik 4.1. Lista czasopism poddanych badaniu z zakresu funkcjonowania sektora publicznego wraz z ich parametrami bibliometrycznymi 2014

Załącznik 4.2. Opis procedury badania bibliometrycznego

Załącznik 4.3. Przynależność partyjna władz stanowiących i wykonawczych samorządowych województw oraz miast (stolic województw) w kadencji 2010-2014 
Załącznik 5.1. Kwestionariusz wywiadu z menedżerami publicznymi badanych OT. Postawa samorządu regionu wobec współdziałania (czyli nawiązywania partnerskich relacji z podmiotami w regionie)

Załącznik 6.1. Lista pytań do wywiadu otwartego

Załącznik 6.2. Nazwy regionów i miast partnerskich, spełniających kryteria zgodności 


\section{Od Redakcji}

Wawrzyniec Rudolf jest pracownikiem naukowo-dydaktycznym Uniwersytetu Łódzkiego. Pracuje w Katedrze Zarządzania Miastem i Regionem, kierowanej przez prof. zw. dr. hab. Tadeusza Markowskiego na Wydziale Zarządzania UŁ. Wcześniej, do 2011 r., adiunkt na Wydziale Studiów Międzynarodowych i Politologicznych w Katedrze Marketingu Międzynarodowego i Dystrybucji kierowanej przez prof. zw. dr. hab. Tomasza Domańskiego.

W działalności naukowej interesuje się możliwością wykorzystania koncepcji marketingu, a szczególnie marketingu relacji w organizacjach publicznych, zwłaszcza jednostkach samorządu terytorialnego. Jest autorem blisko 60 artykułów naukowych z zakresu marketingu terytorialnego, zarządzania publicznego i polityki regionalnej. W latach 2009-2011 kierownik projektu Rola partnerstwa w zarzadzaniu regionem finansowanego przez Ministra Nauki i Szkolnictwa Wyższego, a w latach 2010-2012 współrealizator projektu Marketing jako operacyjne rozwinięcie koncepcji governance $w$ zarzadzaniu publicznym.

W roku 1997, jako doktorant na Wydziale Zarządzania UŁ, aktywnie uczestniczył w organizacji pierwszej w Polsce, międzynarodowej konferencji pt. Marketing terytorialny - strategiczne wyzwania dla miast i regionów. Przed ukończeniem doktoratu odbył staże naukowe na uczelniach w Wielkiej Brytanii (University of Wales) i Francji (Jean Moulin Université LYON III). W roku 2001 obronił doktorat pt. Promocja miasta przemysłowego wobec inwestorów zewnętrznych, bazujący na porównaniach przypadków z Polski, Francji i Wielkiej Brytanii. W latach 2013-2014 w ramach 7. Programu Ramowego odbył staże naukowe w Rosyjskiej Akademii Nauk oraz na Ukrainie (Narodowy Uniwersytet Ekonomiczny). Jest członkiem następujących organizacji naukowych: European Grouping of Public Administration (EGPA IIAS), Congress of Political Economics International (COPE) oraz Polskiego Naukowego Towarzystwa Marketingu (PNTM). 
W ramach działalności dydaktycznej prowadzi zajęcia z marketingu terytorialnego, marketingu $\mathrm{w}$ sektorze publicznym i społecznym oraz europejskiej polityki regionalnej. Kompetencje związane z tym ostatnim przedmiotem wzmocnił $\mathrm{w}$ wyniku otrzymania prestiżowego grantu Jean Monnet Permanent Course (European Regional Policy), który realizował w latach 2002-2007 na Uniwersytecie Łódzkim. W latach 2002-2016 aktywnie uczestniczył w programie LPP Erasmus, w ramach którego wykładał gościnnie na uniwersytetach we Francji, Hiszpanii, Norwegii, Rumunii i Turcji. W latach 2009-2011 reprezentował UŁ w międzynarodowym zespole programu Campus Europae (Humanities and Social Committee).

Z problemami funkcjonowania sektora publicznego zetknął się już w czasie pracy zawodowej (w latach 1994-1996) w Biurze Promocji i Współpracy Międzynarodowej Urzędu Miasta Łodzi, gdzie trafił bezpośrednio po ukończeniu studiów na kierunku zarządzanie i marketing. Podejmował tam pionierskie próby wykorzystania koncepcji marketingu w procesach przyciągania inwestorów i turystów do miasta. Współcześnie jest zaangażowany w politykę rozwoju województwa łódzkiego zarówno na poziomie strategicznym (członek Rady Naukowej, uczestnik Regionalnego Obserwatorium Terytorialnego Województwa Łódzkiego), jak i operacyjnym (ekspert oceniający w ramach Regionalnego Programu Operacyjnego). Reprezentuje m. Łódź w RN Łódzkiego Funduszu Poręczeń Kredytowych. Od 2014 r. pełni funkcję sekretarza Rady Menedżerów Publicznych przy Wydziale Zarządzania UŁ. W ramach tej działalności jest koordynatorem projektów: Prace dyplomowe dla sektora publicznego oraz Spotkania z Menedżerami Publicznymi. 